Universidade de São Paulo

Faculdade de Saúde Pública

\title{
Relações raça e gênero em jogo: a questão reprodutiva de mulheres negras e brancas
}

RAQUEL SOUZAS

Tese de doutorado apresentada ao Programa de Pós-Graduação em Sáude Pública para obtenção do título de Doutor em Saúde Pública

Área de Concentração:

Materno Infantil

Orientadora: Profa $\quad \mathrm{Dr}^{\mathrm{a}}$

AUGUSTA T. DE

ALVARENGA

São Paulo 


\section{Relações raça e gênero em jogo: a questão reprodutiva de mulheres negras e brancas}

RAQUEL SOUZAS

Tese de doutorado apresentada ao Programa de Pós-Graduação em Sáude Pública para obtenção do título de Doutor em Saúde Pública

Área de Concentração: Materno Infantil

Orientadora: Profa $\quad$ Dra AUGUSTA T. DE ALVARENGA

SÃO PAULO

2004 
Autorizo, exclusivamente para fins acadêmicos e científicos , a reprodução total ou parcial desta tese, por processos fotocopiadores.

Assinatura:

Data: 


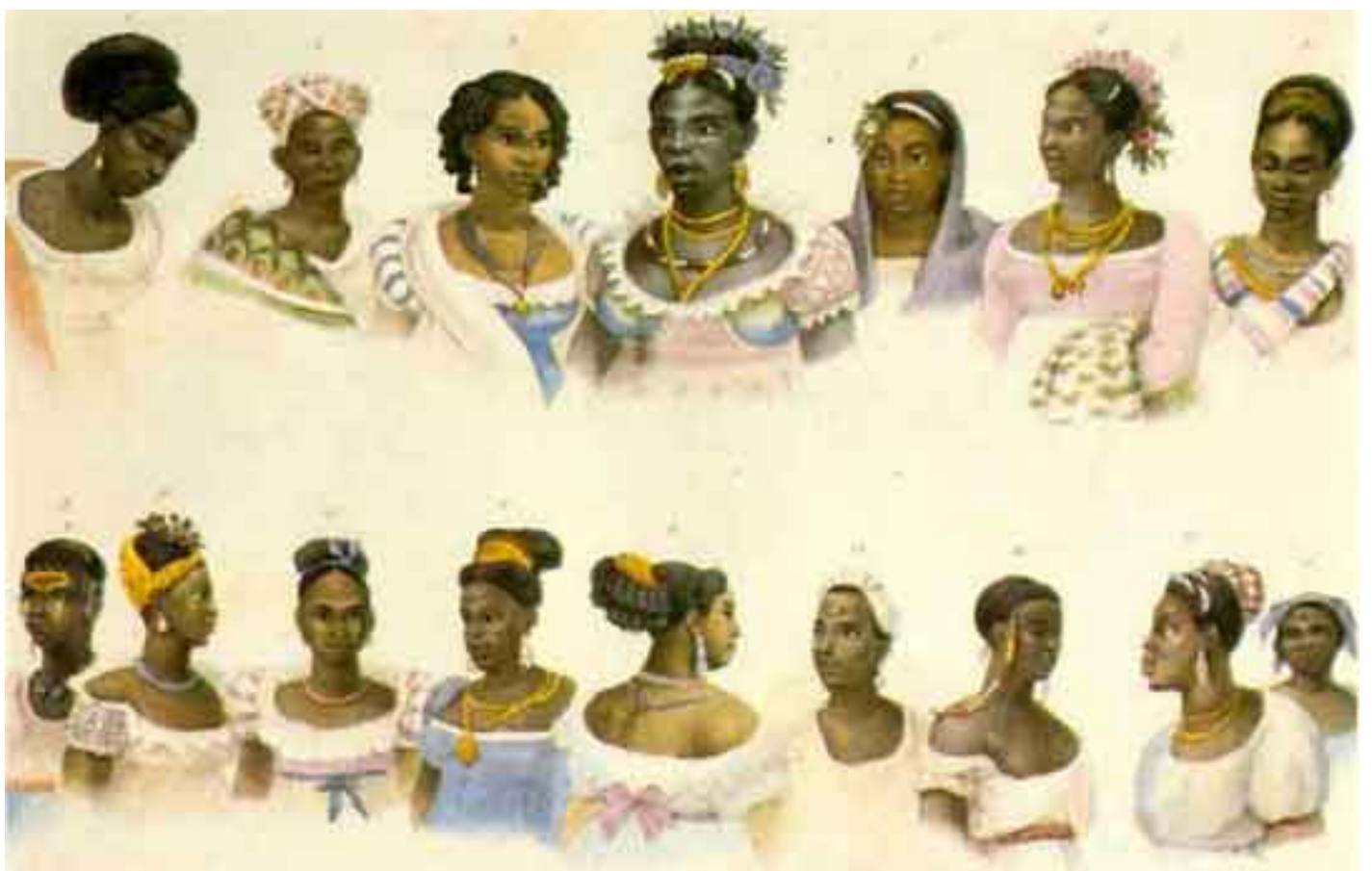

Etnias africanas.

Debret,1835 Biblioteca Mário de Andrade 


\section{AGRADECI MENTOS}

Ao CNPq, pela bolsa de estudos concedida.

À Professora Drạ Augusta Thereza de Alvarenga, minha orientadora.

Ao Professor Titular Kabenguele Munanga, por ter me acompanhado desde a fase de qualificação deste trabalho e por suas importantes observações.

À Professora Dra Izabel Baltar da Rocha Rodrigues, por ter me acompanhado desde a fase de qualificação deste trabalho e pelas preciosas observações.

Ao CEMICAMP/UNICAMP - Centro de Pesquisas Materno-Infantis de Campinas, pelo estágio oferecido.

A Professora Drạ Maria José Osis, por ter me acolhido no CEMICAMP e por aceitar participar da banca examinadora desta tese.

Ao Professor Associado Rubens Adorno, por sua importante contribuição e participação da banca examinadora desta tese.

Ao pessoal da secretaria do Departamento de Saúde Materno Infantil e ao pessoal da biblioteca da Faculdade de Saúde Publica/USP

A todas as mulheres que concederam entrevista e aceitaram abrir suas vidas. 
Às pesquisadoras Vilma Luiza Bokany e Vanderli da Silva, que me ajudaram na pesquisa de campo.

À Professora Dra Marcia Furquim de Almeida, do Departamento de Epidemiologia da Faculdade de Saúde Pública da USP, pelas sugestões na confecção de tabelas, incorporadas ao texto.

À Professora Dra. Maria da Penha Vasconcelos, do Departamento de Saúde Materno Infantil da Faculdade de Saúde Pública da USP pelas sugestões dadas.

A todas as mulheres negras que fizeram história como Lelia Gonzales

À FALA PRETA!Organização de Mulheres Negras que me possibilitou a participação em momentos importantes da recente história do Movimento de Mulheres Negras

Às amigas e companheiras da FALA PRETA! Organização de Mulheres Negras, Elizabeth, Maria Dirce, Glaucia Matos, Deise Benedito, Rosangela Paulino, Benedita e as demais companheiras(os) que me acompanharam na travessia.

À Edna Roland, que abriu os caminhos e me incentivou a compreender e pesquisar a temática de gênero e raça e me proporcionou entender por dentro o movimento de mulheres negras

Aos amigos de todas as tribos. 
À Teresinha Bernardo da PUC

À minha família, por ter tido paciência e compreendido a importância deste trabalho para minha vida. 


\section{RESUMO}

SOUZAS, R. Relações raça e gênero em jogo: a questão reprodutiva de mulheres negras e brancas. São Paulo, 2004 [ Tese de doutorado Faculdade de Saúde Publica da USP]

Introdução: No âmbito das discussões de gênero e raça, as desigualdades que marcam a condição da mulher, nem sempre, são contempladas, ao contrário, há uma série de discursos que visam a naturalizar diferenças, forjadas historicamente. Nesse sentido, indagar sobre o significado dessas diferenças, no âmbito da saúde reprodutiva, apresenta-se como problema de investigação. Nesse campo, decisões e arranjos reprodutivos dos indivíduos partem ou resultam em processos de negociação, não só condicionados pela realidade partilhada entre os mesmos, como pelas ações que são modeladas, segundo valores e normas sociais. Estes se caracterizam por um certo dinamismo e possibilidade de transformação e resignificação. Hipótese e objetivo: Partindo da hipótese básica de que, ao lado da reconhecida transversalidade de gênero, amplamente divulgada na literatura especializada, raça/etnia apresenta-se, igualmente, como tal, nas questões reprodutivas, no presente trabalho propõe-se, como objetivo central, analisar a questão da transversalidade de gênero e de raça, buscando reter de que forma tais transversalidades se apresentam no tratamento de problemas inerentes à área da Saúde Reprodutiva como, por exemplo, da prevenção da gravidez e das DSTs/Aids e como as condições de vida a elas se relacionam. Procedimento Metodológico Pesquisa qualitativa, que utilizou a técnica de história oral- temática. Foram entrevistadas 36 mulheres, 18 negras e 18 brancas, em três segmentos de escolaridade. Foram utilizados um roteiro temático, com questões abertas sobre saúde reprodutiva, gênero, raça, sexualidade e um formulário semi-estruturado, com questões sóciodemográficas e história reprodutiva. Complementarmente, foi realizada uma pesquisa documental, de estudos e documentos significativos para 0 
movimento de mulheres negras, do ponto de vista político, assim como sobre a problemáticada relação racial e saúde, em uma perspectiva sócio-política. Discussão dos resultados: A concepção de liberdade das mulheres negras, de escolaridade superior, grau em que se pressupõe maior autonomia, é mais restrita à vida privada, em razão do racismo que enfrentam na vida pública. Já as mulheres brancas apresentam uma concepção mais ampliada, que inclui a conquista de novos espaços, no âmbito da vida pública. A concepção de casamento para mulheres negras e brancas funda-se em uma concepção de monogamia absoluta, razão pela qual excluem o uso da camisinha. Neste caso, a questão de gênero predomina em relação à raça. Entretanto, a conjugalidade, no sentido moderno do termo, no qual a igualdade de gênero e as negociações são características, apresenta-se como uma construção recente na história de vida de mulheres negras, revelandose como um campo onde, só recentemente, estas conquistaram espaço. Com relação aos métodos contraceptivos, é possível apontar, a partir de uma caracterização dos sujeitos da pesquisa, que as mulheres negras entrevistadas, nas escolaridades média e fundamental, seguem, quando cotejadas com a literatura especializada, um padrão de uso massificado de métodos contraceptivos, ou seja, referem mais o uso da laqueadura e da pilula, e, no nível superior, referem mais o uso da camisinha. Por outro lado, as mulheres brancas entrevistadas fazem uso diversificado de métodos em todas as escolaridades, destacando-se o que se caracteriza, na maioria dos casos, uma opção por método de controle masculino, como vasectomia e camisinha. Quando abordada a questão da negociação para a prevenção da gravidez e das DST/Aids, observa-se menor autonomia de mulheres negras, de escolaridade média e fundamental, em relação às mulheres brancas e negras, de escolaridade superior. Na medida em que não se observa diferença, nesse processo de negociação, entre mulheres negras e brancas, com escolaridade universitária, a investigação aponta, igualmente, para a questão da diferenciação social. Conclusão Diante dos resultados obtidos, a presente investigação aponta para a riqueza de pesquisas que contemplem 
as intersecções existentes entre gênero, raça e desigualdade social no contexto da saúde reprodutiva.

Palavras-chave: Mulher, Saúde Reprodutiva, Raça/Etnia, Gênero, Condições de vida, Escolaridade

\section{SUMMARY}

SOUZAS, $R$ Relations of race and gender in the game: the reproductive issue of the black and white women. São Paulo, 2004[Tese de doutorado - Faculdade de Saúde Publica da USP]

Introduction Within discussions of gender and race, the inequalities that characterize the condition of black women are not always discussed. On the contrary, there are several speeches that seek to make differences that have been historically forged look natural. To that respect, to question the meaning that such differences acquire in the domain of reproductive health becomes a relevant matter of investigation. Within this field, the decisions and reproductive arrangements made by individuals come or result from the negotiation processes not only conditioned by the reality they share, but by actions that are shaped according to a set of values and social norms. This set is characterized by a certain dynamism and the possibility of transformation and resignification. Hypothesis and objective: coming from the basic hypothesis that, besides the recognized gender bias widely disseminated by the specialized literature, race/ethnicity is also likewise presented on reproductive issues, the main goal of this work is to analyze the issue of gender and race bias, seeking to keep in mind how such biases are presented on the handling of problems inherent to the area of Reproductive Health like for instance, HIV/STD and pregnancy prevention, and how life conditions are related to them. Methodological procedure: qualitative research using the oral, thematic history technique. The subjects interviewed were 36 women, 18 black and 18 white, from three different educational backgrounds. During the interview process, a thematic list of topics for discussion with open questions about reproductive health, gender, 
race, sexuality, and a semi-structured form with socio-demographic questions and reproductive history were used. Complementarily, we researched some documents that we consider meaningful from the political point of view for the black women's movement. Discussion of Outcomes: black women's conception of freedom, of those with higher education, when one has supposedly greater autonomy, is more restricted to the private life due to the racism they face in public life. White women, on the other hand, show a broader conception, which includes the conquest of new spaces within public life's realm. Marriage's conception, both for black and white women, is based on a conception of total monogamy, hence their exclusion of using preservatives. In this case, the issue of gender prevails over race. Nonetheless, the connubiality, at the modern meaning of the term, which is characterized by equality of gender and negotiations, indicating to be a recent construction in the history of black women' lives, field in which only recently they conquered space. Regarding the birth control methods, it is possible to point out from the characterization of the research's subjects, that the black women interviewed, from elementary and middle school education background, follow, when compared to the specialized literature, a pattern of massive use of birth control methods, that is, they refer more to the use of tubal ligation and birth control pill, and at the higher education level, refer more to the use of preservatives. On the other hand, the white women interviewed use more diversified birth control methods in all education levels, standing out what is characterized in most cases a choice for a male controlled method such as vasectomy and preservatives. When the issue of the negotiation of HIV/STD and pregnancy prevention is surveyed, one can notice a lower autonomy of black women, with elementary and middle school education background, in comparison to white and black women with higher education background. As this difference is not observed during this process of negotiation among black and white women with higher education background, the investigation points towards the same direction to the issue of social differentiation. Conclusion: from the 
outcomes obtained, the current investigation indicates the richness of researches that contemplate the existing intersections between gender, race, and social inequalities in the context of reproductive health.

Key words: Women, Reproductive Health, Race/Ethnicity, Gender, Life Conditions, Education 
ÍNDICE

1.I NTRODUÇÃO.

2. GÊNERO E RAÇA: INTERSECÇÃO NO CAMPO DA SAÚDE REPRODUTI VA................15

2.1 SAÚDE EM MOVI MENTO E AS MULHERES NEGRAS ...................................................... 18

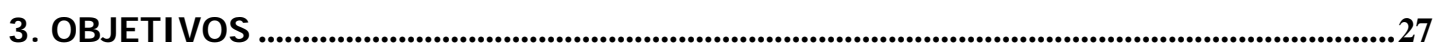

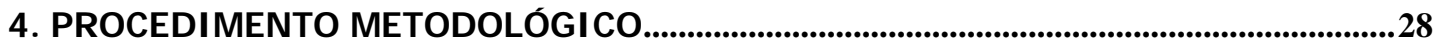

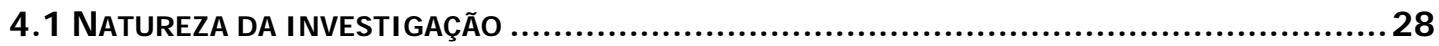

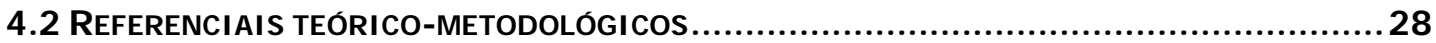

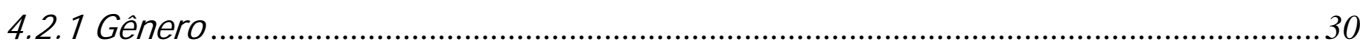

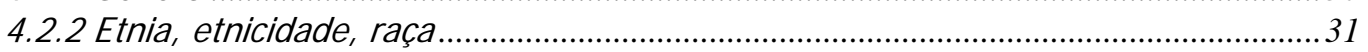

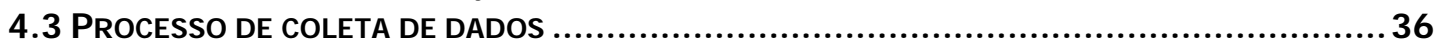

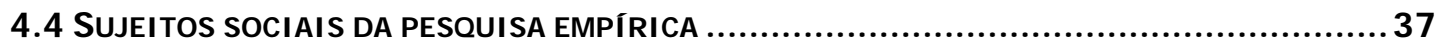

4.5 TÉCNI CA DE TRATAMENTO PARA ANÁLISE DOS DISCURSOS DOS SUJ EITOS DA PESQUI SA ..... 39

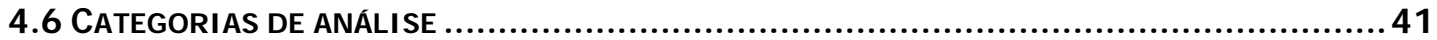

5. CARACTERI ZAÇÃO DAS ENTREVISTADAS .................................................. 42

6 DESVELANDO RELAÇÕES ESPECÍ FI CAS ENTRE CONJ UGALI DADE, GÊNERO E RAÇA, NO CONTEXTO DA SAÚDE REPRODUTIVA...........................................................52

6 .1 VISÕES DE MUNDO ACERCA DE SER “MULHER”, HOJ E EM DIA....................................54

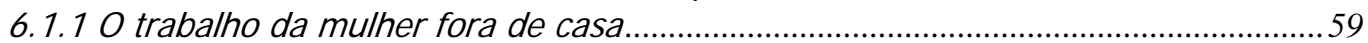

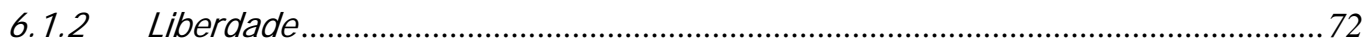

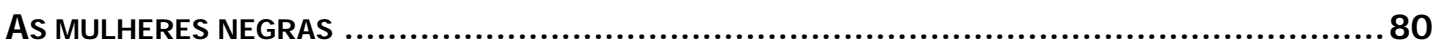

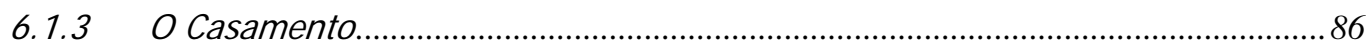

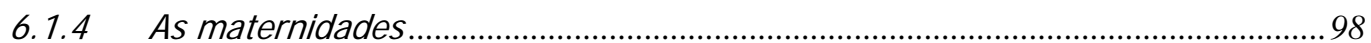

6.2 ..... I I DÉ AS DE NEGRURA, I DÉI AS DE BRANCURA, NA ÓTI CA DE MULHERES NEGRAS E BRANCAS

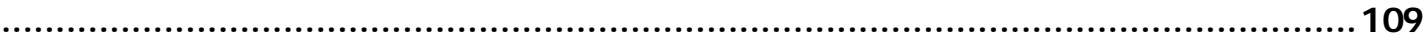

6.3 VISÕES DE MUNDO, ACERCA DA DI FERENÇA …...................................................116

7. CARACTERI ZANDO PRÁTI CAS SOCI AIS HOMOGÊNEAS E DI FERENCI ADAS EM RELAÇÃO À PREVENÇÃO DA GRAVI DEZ E DO HI V/ AI DS, NA I NTERSECÇÃO CONJ UGALIDADE, RELAÇÕES DE GÊNERO E RAÇA.....................................................130

7. 1 USO DE MÉTODOS CONTRACEPTIVOS ............................................................... 130

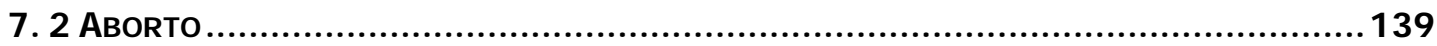

8. I DENTI FI CANDO DI LEMAS E CONTRADI ÇÕES NAS PRÁTI CAS CONTRACEPTIVAS E NA PREVENÇÃO DO HIV/ AIDS, SOB A ÓTI CA DAS RELAÇÕES

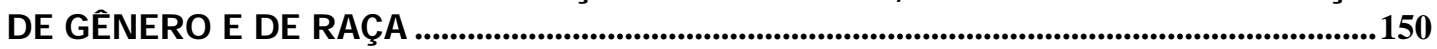

8. 1 LAQUEADURA: UMA MEDI DA RADI CAL .............................................................. 150

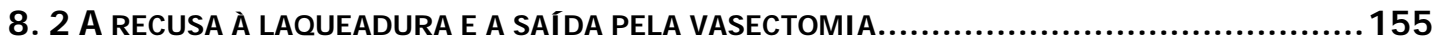

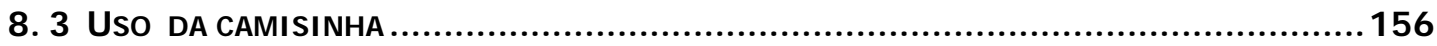

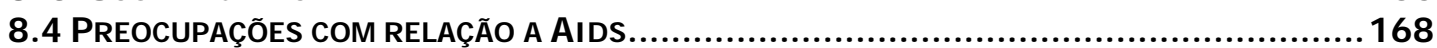

8.4.1 A mulher negra laqueada e não usuária da camisinha.............................................172

8.5 O PACTO CONJ UGAL ...................................................................................... 173

9. A CONJ UGALI DADE DE MULHERES NEGRAS E BRANCAS .......................................176

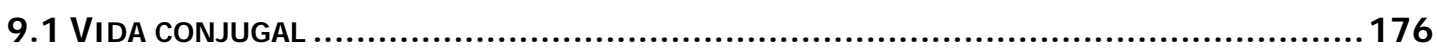

9. 2 A SEXUALI DADE DE MULHERES NEGRAS E BRANCAS ..............................................189 
10. O DISCURSO SOBRE A DISCRI MI NAÇÃO DE GÊNERO E RAÇA .............................203

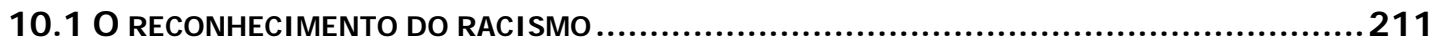

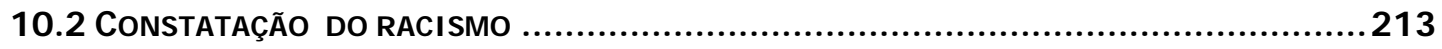

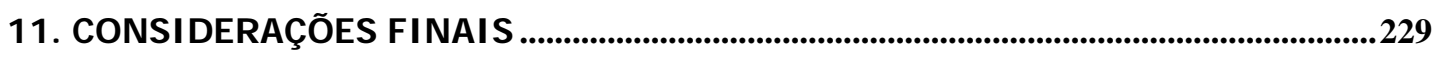

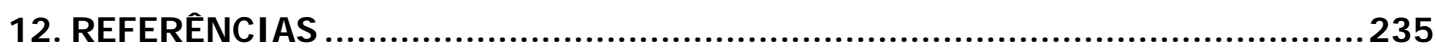

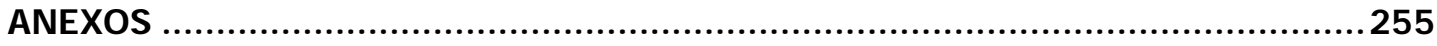

ANEXO I FORMULÁRI O SEMI - ESTRUTURADO DE ENTREVI STA ........................................ I

ANEXO II ROTEI RO TEMÁTI CO PARA ENTREVISTA EM PROFUNDI DADE........................... I I I

ANEXO I V: CONSENTI MENTO LIVRE E ESCLARECI DO.................................................. V I I

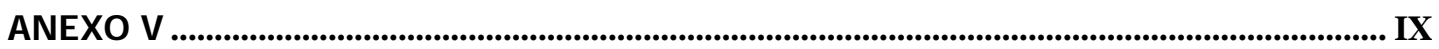

CARACTERI ZAÇÃO DO GRUPO ENTREVISTADO......................................................... IX 


\section{INTRODUÇÃO}

A reflexão acerca das questões sociais pode explicitar algumas das facetas e dilemas sociais brasileiros e resolver enigmas construídos como, por exemplo, se o problema do negro é porque ele é pobre, ou porque ele é negro. Este dilema não se resolve facilmente e alguns pesquisadores afirmam que o negro é pobre, porque é negro. De fato, constata-se que há uma aceitação da pobreza negra como evidente. Para GUIMARÃES (2000), em primeiro lugar, quando comparados aos brancos, os negros (negros e mulatos) apresentam menor escolaridade, renda familiar per capita menor em quase 50\%, famílias mais numerosas, maior número de residentes em zonas rurais e nível ocupacional mais baixo. Em segundo lugar, a nossa hierarquia social demonstra a importância que assumem a escolaridade e 0 domicílio urbano. Para ele, em todos os estratos ocupacionais, a rentabilidade dos negros é, em média, quase metade da dos brancos. Em terceiro lugar, menciona que o sexo e a cor são importantes fatores de discriminação, em termos de renda, na distribuição da pobreza. Nos dados apresentados por esse autor, homens brancos têm, em relação à distribuição da pobreza, uma renda média de 6.3 (salários mínimos), mulheres brancas, 3.6, homens negros, 2.9 e mulheres negras, 1.7. Esta distribuição de renda na pobreza revela o quanto as mulheres negras são prejudicadas, por questões de gênero e raça combinadas.

Segundo esse mesmo autor (GUIMARÃES 2000), mulheres negras estão mais sujeitas ao desemprego no mercado de trabalho do que mulheres brancas, e, ainda que, homens negros e brancos participem, em igual proporção, no mercado de trabalho, o desemprego é maior entre negros. BENTO (2000), ao discutir sobre o mercado de trabalho, aponta que as desigualdades raciais, historicamente constituídas, não só se mantiveram, como também recrudesceram em alguns casos, a exemplo da região Sudeste 
do Brasil, que apresenta altas taxas de desenvolvimento econômico. Aponta que a situação da mulher negra, nesse contexto, é de precariedade no mercado de trabalho e de sujeição a mecanismos de discriminação no processo de seleção, promoção, treinamento e demissão. Neste particular, coloca a autora, a "boa aparência" segue padrões eurocêntricos e impede o acesso e/ou permanência de mulheres negras no trabalho. Isto é coerente com o que foi apontado por GUIMARÃES ( 2000).

No Brasil, segundo GUIMARÃES (2000), a taxa de pobreza absoluta é quase 0 dobro para os negros, em relaçao aos brancos. Em todas as regiões do país, a pobreza afeta mais os negros do que os brancos e, agregado a isto, ideologicamente, prevalece a idéia da equivalência entre ser negro e pobre, por um lado, e branco e rico, por outro.

Esse mesmo autor argumenta que a primeira resposta/justificativa que tem sido dada é a de que se trata de uma herança de um passado escravista. Em sua análise, essa "explicação" exime as gerações presentes da desigualdade atual, oferece desculpa para a permanência da desigualdade, sugere que os problemas se resolverão com o crescimento da economia. Para lideranças negras, prossegue, a pobreza negra se traduz na falta de oportunidades e prejuízos da discriminação, argumentos esses que foram rechaçados por aqueles que acreditam ser a pobreza negra, somente pobreza, sem discriminação racial, reduzindo à condição de classe a explicação da condição do negro na realidade brasileira.

O discurso da "democracia racial" explica a pobreza como resultado do passado escravista e o prejuízo da discriminação, como resultado da condição de classe, ou seja, discriminação dos pobres. GUIMARÃES (2000) chama a atenção, também, para o "ciclo acumulativo de desvantagem", assinalado por HASENBALG (1983) e SILVA (1998). As estatísticas demonstraram, aponta HASENBALG (1983), que as desvantagens dos negros não são somente produto do passado, sendo a discriminação racial um fator 
de grande impacto no presente. A discriminação racial, no Brasil, apresentase, geralmente, diluída em atributos pessoais e, neste sentido, homens e mulheres negros, conforme GUIMARÃES (2000), têm renda inferior à de brancos, estes chegando a ganhar duas vezes mais que os negros.

A questão racial no Brasil requer discussão sobre a identidade negra no Brasil, de forma mais abrangente do que usualmente se faz. Podemos dizer que tal identidade "seria a identidade política de um segmento importante da população brasileira, excluída de participação política" (MUNANGA 1990:113).

As idéias expostas sobre a questão racial são extremamente importantes, por colocarem três questões em pauta: a primeira, diz respeito ao fato de a população negra constituir parte significativa da população excluída; a segunda, que se trata de um segmento que se auto-classifica como negro; e a terceira, que há uma identidade abrangente, que aponta para as desigualdades de raça/etnia entre negros e brancos e, até mesmo, para sua exclusão social.

A idéia nuclear é a de que ser negro, quase sempre, implica viver em más condições e sob uma dada vulnerabilidade social, que tem a cor como indicador. De fato, PAIXÃO (2003) aponta que o Brasil negro ocupa a $106^{\mathrm{a}}$ posição no ranking do IDH ( Índice de Desenvolvimento Humano), enquanto o Brasil branco ocupa a $46^{\mathrm{a}}$ posição. É uma diferença significativa, que revela que a população negra vive em clara desvantagem em relação à branca. Se, em nível da retórica, a questão racial pode ser identificada mais facilmente como forma de exclusão social, no campo das relações cotidianas isso é mais difícil, haja vista a enorme dificuldade para nomear, identificar e localizar aqueles que seriam as vítimas da discriminação. Isto, por que o mito da democracia racial obscurece a problemática. Tais dificuldades se justificam pelos dilemas que se projetam da subjetividade da população negra - que, muitas vezes, obnubilam a indisfarçável condição de desigualdade em que 
está imersa - e, também, em razão dos resquícios do racismo e do "mito da democracia racial", inculcados na população brasileira. É preciso ver que o "mito da democracia racial", quase sempre apresentado como o que obscurece episódios de discriminação, visa a representar a integração das raças como uma realidade, cuja prova material seria um país em que a discriminação étnico-racial não existiria, território comparável a uma "ilha de tranqüilidade", em face de outros países onde a discriminação seria, supostamente, mais virulenta (SCHWARCZ 1998).

Por sua vez, mecanismos de exclusão e desigualdade revelam a idéia de sujeição, atrelada à idéia de subordinação social, que foi historicamente construída, por intermédio do processo de escravização da população negra. Tais mecanismos podem ser explicados por meio das considerações sobre a violência simbólica, exercida contra os excluídos de toda ordem (BOURDIEU 1989,1992,1996,1998). Ou, serem vistos por meio da relação de sujeição, instituída em uma dada ordem social e na construção de saberes sobre uma população sob dominação social (FOUCAULT 1993), o que seria de grande valia para ajudar a compreender a questão racial. Para MUNANGA (1998), no entanto, o racismo beneficia brancos, não por serem dominantes, mas por serem brancos. Isso nos obriga a pensarmos no conteúdo simbólico de ser branco e ser negro no Brasil.

A situação da mulher negra é ainda mais grave, conforme atestam os dados apresentados na tabela 1, a seguir. Além de ganharem menos, homens e mulheres negros ainda têm uma esperança de vida menor que homens e mulheres brancos, o que modifica a informação mais freqüente de as mulheres viverem mais. Conforme se observa, a mulher branca tem 9 anos de vida, a mais, na expectativa de vida, em relação às negras. 
Tabela 1. Rendimentos per capita e esperança de vida, Brasil, 1997

\begin{tabular}{lcc}
\hline & $\begin{array}{c}\text { Renda } \\
\text { (em Salários } \\
\text { Mínimos) }\end{array}$ & $\begin{array}{c}\text { Esperança de vida } \\
\text { (em anos) }\end{array}$ \\
\hline Mulheres Negras & 0,76 & 66 \\
Homens Negros & 1,96 & 62 \\
Mulheres & 1,88 & 71 \\
Brancas & 4,74 & 69 \\
Homens Brancos & &
\end{tabular}

Fonte: Paixão (2003)

No Estado de São Paulo, é possível apontar algumas diferenças na questão da saúde, quando se comparam a população negra e a branca. No quadro 1, podemos observar que, no ano 2000, a população negra representava 26,2\% da população geral no Estado de São Paulo. Os homens negros correspondiam a $26,2 \%$ da população e as mulheres, a $26,1 \%$. A taxa de fecundidade, para as negras, era de 2,5 filhos, enquanto para as brancas, 1,9 filhos e, na média, 2,1 filhos por mulher. Levando em conta que a população negra representa $26,2 \%$ da população geral no Estado, este grupo estava sobre-representado $(42,6 \%$ das mulheres negras e $29 \%$ dos homens negros) no grupo com doenças crônicas. É menor a proporção de negros, acima dos 15 anos de idade, que possuem cobertura por plano de saúde. Sendo assim, usam mais o Sistema Único de Saúde - SUS (SEADE 2000). 
Quadro 1 - Dados comparativos da população Negra e Branca, Estado de São Paulo, 2000

\begin{tabular}{|l|l|}
\hline Proporção da população negra na população geral & $26,2 \%$ \\
\hline Proporção de homens negros no total de homens & $26,2 \%$ \\
\hline Proporção de mulheres negras entre as mulheres & $26,1 \%$ \\
\hline Taxa de fecundidade total & 2,1 filhos por mulher \\
\hline Taxa de fecundidade das mulheres negras & 2,5 filhos por mulher \\
\hline Taxa de fecundidade das mulheres brancas & 1,9 filhos por mulher \\
\hline $\begin{array}{l}\text { Participação de homens negros no grupo de portadores de } \\
\text { doenças crônicas }\end{array}$ & $29 \%$ \\
\hline $\begin{array}{l}\text { Participação de mulheres negras no grupo de portadores de } \\
\text { doenças crônicas }\end{array}$ & $42,6 \%$ \\
\hline
\end{tabular}

Fonte: Fundação SEADE (2000)

A Pesquisa de Condições de Vida, na região Metropolitana de São Paulo, da Fundação SEADE - Mulheres segundo Origem Étnica -, apresenta o amplo desfavorecimento da mulher negra na década de 90 . Segundo dados da Pesquisa, foi possível mostrar que mulheres negras ocupam, em maior proporção, a posição de chefes de família, nos estratos socioeconômicos mais baixos. Principalmente nos estratos $C$ e $D$, são, também, aquelas portadoras de menos anos de estudo, são, em maior proporção, empregadas domésticas, sem carteira assinada, e com menor rendimento.

Postas tais reflexões, a respeito do problema social da discriminação no Brasil, resta-nos pensar, com base em novas considerações, quais seriam as implicações dessa questão no campo da saúde.

A princípio, vê-se, com clareza, que existem condições de vida e de morte distintas para negros e brancos, como podemos constatar, a título de exemplo, pelos índices que acusam uma taxa maior de mortalidade infantil entre as crianças negras: 
"as mães negras, residentes em áreas rurais, experimentavam, para cada mil nascidos vivos, 67 mortes a mais de filhos, menores de um ano, que as mulheres brancas" (CUNHA 2001:50).

Dadas as desigualdades regionais, observa-se, também, que mães do Nordeste, por seu turno, estão sujeitas a um "risco de morte $44 \%$ superior que o da Região Sul, com valores [coeficientes] de 66 e 37 mortes de menores de um ano por mil nascidos vivos, respectivamente" (CUNHA 2001:50). Segundo a autora dessa pesquisa, o controle de variáveis, como raça, e socioeconômicas, do tipo renda, grau de instrução e grupo sócioocupacional, não explicam as diferenças entre brancos e negros. Isso quer dizer que as raízes do problema são mais profundas e não podem ser reduzidas ao tratamento estatístico de relação entre variáveis isoladas.

Para a mortalidade materna, no Estado do Paraná, temos, por exemplo, que:

"O risco relativo de morte materna foi 7,4 vezes maior nas pretas que nas brancas, e 5 vezes maior entre amarelas" (MARTINS 2001: 39).

Assim, podemos observar que a questão racial apresenta-se, para os pesquisadores, como um dilema para a construção de um saber no campo da saúde. Publicação nessa área, e de grande utilidade para nós, é o Livro da Saúde da Mulher Negra (2000), que expõe vários estudos e depoimentos sobre a condição da mulher negra e saúde. Entre esses, destacamos o relato sobre a dificuldade de coletar dados referentes à prevalência de miomas uterinos em mulheres negras (SOUZA 2000); o estudo sobre síndromes de anemia falciforme (OLIVEIRA 2000); depoimentos sobre aborto (ROLAND 2000); uma reflexão sobre a saúde mental em grupos de auto-ajuda (PINTO, BOULOS, ASSIS 2000); mulher negra e obesidade (NOGUEIRA 2000); reflexão sobre violência doméstica (WHITE 2000); e outros trabalhos que tratam, particularmente, da saúde da mulher negra, tendo em vista a vulnerabilidade à Aids. 
As desigualdades que marcam a condição da mulher negra, no Brasil, nem sempre vêm à baila. De acordo com PERPÉTUO (2000), as mulheres negras vivem em regiões menos desenvolvidas e estão nos estratos educacionais e socioeconômicos inferiores da sociedade. Constata-se, ainda, que a população negra, sob risco reprodutivo, é substantivamente maior do que a de outras populações, como também é maior a proporção de mulheres negras, que iniciam mais cedo a vida sexual e logo têm o primeiro filho. Via de regra, têm três ou mais filhos. Conforme, ainda, o levantamento feito por Perpétuo, verifica-se o precário acesso dessas mulheres a anticoncepcionais e boa parcela das mulheres entrevistadas que não usava nenhum contraceptivo na ocasião da pesquisa. Por outro lado, entre as que faziam uso de algum deles, a pílula e a esterilização responderam por $83 \%$, sete por cento a mais do que entre mulheres brancas (76\%).

PERPÉTUO (2000) revelou, também, que jovens mulheres negras têm um precário conhecimento da fisiologia reprodutiva, o que se reflete nos altos índices de falha do método contraceptivo adotado. Mulheres negras têm, segundo a autora, menor acesso à assistência obstétrica, seja durante 0 pré-natal, seja durante o parto e o período puerperal, o que seria importante para o combate da mortalidade materna, que apresenta altos coeficientes no Brasil.

É possível constatar, ainda, que mulheres negras receberam tratamento desigual na assistência pré-natal, para a qual é preconizado um "pacote mínimo" de consultas e atendimentos. Sinal claro dessa diferenciação é o menor acesso delas ao tratamento ginecológico, ao qual elas, em tese, teriam igual direito, sobretudo porque esse é um instrumento importante para controle das DST's e para prevenção do câncer ginecológico (PERPÉTUO 2000: 14).

Nesse contexto, em que há primazia da pobreza para os negros e vantagem para os brancos, há confrontos de subjetividades, especialmente 
para as questões reprodutivas, em que a questão da subjetividade toma grande vulto. Isso, porque é, dentro desse campo de confrontos e possibilidades, que escolhas reprodutivas ocorrem; questões raciais e de gênero emergem; e realidades socioculturais se configuram.

Ainda no campo da saúde, a esterilização foi objeto de inúmeros debates e pesquisas, motivados por uma suspeita levantada pelo Movimento Negro (HASENBALG 1998), de que teria havido esterilização, em massa, de mulheres negras. Isso acabou não sendo confirmado em pesquisa elaborada por BERQUÓ (1994), que atribui as altas taxas de esterilização a uma cultura que se formou em torno dessa prática, nas diferentes camadas sociais. 0 que é ratificado por CHACHAM (2001: 44):

"As dificuldades de acesso a uma ampla variedade de métodos contraceptivos e seu uso pouco eficiente, devido à má qualidade do acompanhamento médico, favoreceram que a esterilização se tornasse o principal recurso para suprir a demanda das mulheres por meios para regular sua fecundidade".

De acordo com CECATTI, PIRES e GOLDENBERG (1999), a questão da esterilização adquiriu grande complexidade. Existe uma associação entre esterilização e a freqüência de cesáreas no Brasil. Conforme os autores, a via do parto está relacionada com o poder aquisitivo da parturiente e, avaliando fatores raciais com a via do parto, verificaram que gestantes negras têm maior probabilidade de terem o parto via vaginal. A partir de dados da Pesquisa Nacional de Demografia e Saúde (PNDS 1996), BERQUÓ (1999) salienta que as mulheres com menores recursos educacionais, brancas e negras, não diferem quanto à prática de esterilização e que é, dentre as que têm maior nível de escolaridade, que mulheres negras apresentam taxas mais elevadas de esterilização. Entretanto, outros autores, como SCAVONE (1999) e GUALBERTO (2003), problematizam essa questão e apontam outros aspectos da laqueadura e que diferenciam mulheres brancas e negras. 
SCAVONE (1999) assevera que a consagração da prática da esterilização feminina, como método de anticoncepção no Brasil, colocou várias questões como, por exemplo, sua aplicação como política demográfica no país e controle da população mais pobre e de raça negra. GUALBERTO (2003), baseado em dados da PNDS (1996), verificou que mulheres negras, não usuárias de nenhum método, comparadas às brancas em igual condição, têm mais chances de adotarem a esterilização como método.

Aprofundando as reflexões sobre a esterilização, em si, observa-se que a laqueadura apresenta-se como um método moderno e radical, quanto à sua efetividade, e que se mostra adequada para relações, em que ocorre menor negociação entre os parceiros. Isto pode ser verificado no trabalho de OSIS (2001), por exemplo. GUALBERTO (2003) também analisou o status (posição) da mulher e grau de autonomia, tendo verificado que mulheres de menor autonomia são aquelas de menor escolaridade e renda. Essas informações sugerem, por um lado, que mulheres que buscam métodos radicais, com maior freqüência, exigem menos a negociação cotidiana junto ao parceiro para o uso de um método contraceptivo. Por outro, coloca outra questão importante, qual seja, o processo de medicalização do corpo feminino, que ocorreu ao longo dos séculos. Como aponta VIEIRA (1999), o corpo feminino foi sendo gradativamente medicalizado e transformado em objeto da tecnologia médica, com isso as mulheres foram perdendo autonomia e, mesmo, direitos sobre o seu próprio corpo. Isto se verifica no processo de criação da obstetrícia, quando as parteiras foram sendo excluídas da cena do parto, e houve a gradativa transformação do parto em ato médico. Com isso, as mulheres foram perdendo a autonomia em relação ao próprio corpo.

A medicalização, como assinala VIEIRA (1999), atinge diferentes campos ou dimensões da vida das mulheres. 0 sexo, a raça e as idades, entre outras características, também foram medicalizados. Esse processo contribuiu no sentido de naturalizar diferenças constituídas historicamente, 
as quais passaram a ser compreendidas e/ou explicadas como "naturais" ou adquiriram explicações biologizantes.

A descontrução, tanto da categoria "mulher", como da categoria "negro", assim como a historicização dessas categorias, geraram, no caso de "mulheres", uma reflexão sobre a condição feminina, a construção do conceito de gênero e diferentes leituras. No caso dos "negros", diferentes movimentos contra o racismo revelaram, também, que o conceito de raça é, a exemplo da categoria de gênero, relacional. Retomando nossa proposição inicial, isto significa dizer que ser negro, no Brasil, é diferente de ser negro nos E.U.A, por exemplo.

A alteridade passa a constituir, então, um conceito fundamental para a construção da noção de raça e de gênero. Na condição de conceitos relacionais, diferenciam-se de acordo com as relações constituídas e de acordo com condições historicamente dadas. Neste sentido, é relevante reconhecer como mulheres negras e brancas, em diferentes posições sociais, pensam a sua condição de "mulher" e de "negra".

A emergência de sujeitos de direito e, ao mesmo tempo, a nova dinâmica das relações sociais, no Brasil, acrescentam novos significados à questão da discriminação racial no campo da saúde. Nesse sentido, as reflexões de Hannah Arendt são bastante pertinentes, pois esta concebe 0 mundo real como aquilo que resulta da interação de homens plurais. Tratase de um mundo em que a diversidade permite a construção de relações sociais, e a sociabilidade é garantida pela esfera da comunicabilidade. Nesse âmbito de relações e sociabilidade, a violência é o que destrói a interação, fruto da ética do mundo privado que busca impor-se (TELLES 1999).

No contexto de discussão da saúde, em específico, no tocante à saúde da mulher, a década de 90 marca época. Nela, ganham relevo os conceitos de saúde reprodutiva, direitos reprodutivos, direitos sexuais da mulher 
(GALVÃO 1999:172). Esses conceitos, retirados dos relatórios das Conferências do Cairo (ICPD 1994) e Beijing (1995), são assim definidos:

"Saúde reprodutiva: A saúde reprodutiva é um estado de completo bem-estar físico, mental e social, e não ausência de enfermidade ou doença, em todos os aspectos relacionados ao sistema reprodutivo e a suas funções e processo. Conseqüentemente, a saúde reprodutiva implica a capacidade de desfrutar de uma vida sexual satisfatória e sem risco, de procriar, bem como implica a liberdade para escolher entre fazê-lo ou não, no período e na freqüência desejada. Nessa última condição, encontram-se implícitos os direitos do homem e da mulher de serem informados e de terem acesso a métodos de planejamento familiar seguros, efetivos, aceitáveis e de custos acessíveis, assim como o direito de buscarem/usarem métodos de sua escolha para a regulação da fecundidade e que não estejam legalmente proibidos. Está, também, implícito o direito de receber serviços apropriados de atenção à saúde que permitam gravidez e parto sem riscos e ofereçam aos casais as melhores possibilidades de terem filhos sadios. Define-se como atenção à saúde reprodutiva o conjunto de métodos, técnicas e serviços que contribuam para a saúde e o bem-estar reprodutivos, mediante a prevenção e solução dos problemas de saúde reprodutiva. Inclui-se, também, a saúde sexual, cujo objetivo é a melhoria da vida e das relações pessoais, e não somente 0 aconselhamento e a atenção referentes à reprodução e às doenças sexualmente transmissíveis (ICPD 1994, cit. GALVÃO 1999:172).

Direitos reprodutivos Os direitos reprodutivos abrangem certos direitos já reconhecidos nas leis nacionais e nos documentos internacionais legais sobre direitos humanos, incluindo:

- O direito básico de todos os casais e indivíduos de decidirem livre e responsavelmente sobre o número de filhos e 0 intervalo entre eles, e de disporem da informação, educação e dos meios para tal; 
- o direito de alcançar o nível mais elevado de saúde sexual e reprodutiva;

- o direito de tomar decisões referentes à reprodução, sem sofrer discriminação, coações nem violência (ICPD 1994, cit. GALVÃO 1999: 172)

Direitos sexuais da mulher. Os direitos humanos da mulher incluem o seu direito de ter o controle e decidir livremente e responsavelmente sobre problemas relacionados com sua sexualidade, incluindo a saúde sexual e reprodutiva, livre de coerção, discriminação e violência. Relações de igualdade entre homens e mulheres, no tocante a relações sexuais e reprodução humana, incluindo respeito total pela integridade do indivíduo, requerem respeito mútuo, consentimento e responsabilidade de ambos pelo comportamento sexual e suas conseqüências (Beijing Plataform of Action, Paragraph 97, 1995, cit. GALVÃO1999:172)".

A relevância das reuniões de Cairo (1994) e Beijing (1995), para o campo da saúde da mulher, pode ser observada nas diferentes ordens de questões que passam a nortear a discussão no mesmo e na maior abrangência que a área passa a assumir.

Por pressuporem, por exemplo, a impossibilidade de tratar, sobretudo, as questões reprodutivas, desvinculando as relações existentes entre mulheres e homens, os documentos das referidas reuniões reiteram a importância de se trabalharem as questões da Saúde Reprodutiva e Saúde Sexual à luz das relações de gênero, o que imprime nova dinâmica às pesquisas e atividades realizadas no novo campo, ora denominado Saúde Reprodutiva, por melhor caracterizá-lo.

A historicidade dessas propostas pode ser apreendida a partir de outras análises realizadas por cientistas sociais, sobre a realidade atual do mundo moderno. 
Para autores, como GIDDENS (1996;1991;1996), a realidade atual, caracterizada pelo modernismo, apresenta uma crescente transformação no campo da intimidade, transformação essa orquestrada pelas mudanças nas relações de gênero. Para esse autor, as relações conjugais tradicionais retratariam uma certa dicotomia, em que os papéis sexuais são prédefinidos, ao passo que as modernas relações conjugais se caracterizariam por um certo dinamismo e flexibilidade nos papéis sexuais. É nesse contexto que a democracia, na intimidade, se fundaria na igualdade de direitos de homens e mulheres, em que os direitos sexuais da mulher, reprodutivos e saúde reprodutiva e sexual expressariam o usufruto da liberdade e poderiam, acrescentaríamos, responder às novas propostas de políticas de saúde, como as defendidas nas reuniões de Cairo (1994) e Beijing (1995).

Tendo em vista esse amplo panorama é que consideramos a relevãncia de tratarmos, aqui, a questão da transversalidade do gênero e da raça, buscando perceber de que forma essa transversalidade se apresenta no campo da Saúde Reprodutiva, e como tais condições de vida podem se apresentar em relação a problemáticas como, por exemplo, a da prevenção da gravidez e das DSTs/Aids. 


\section{GÊNERO E RAÇA: INTERSECÇÃO NO CAMPO DA SAÚDE REPRODUTIVA}

A visibilidade da intersecção entre gênero e raça materializa-se no corpo, ou é neste corporificado, o qual configura um modo de existir, uma situação, um campo de possibilidades culturais "recebidas e reinterpretadas", como bem assinala SAFFIOTI (1992: 190). Para essa autora, gênero e raça constituem diferenças, sejam elas sociais, culturais, ou mesmo biológicas, que constróem o poder. 0 corpo se apresenta, nesse particular, como suporte de culturas e relações sociais e, mais especificamente, de relações de poder.

A "condição" biológica de mulheres negras e brancas, especialmente aquela ligada à sua condição reprodutiva, não estabelece e nem mesmo é suficiente para instaurar uma dada igualdade, do ponto de vista do poder no campo relacional, pois essa condição, tanto é base para ingerências de inúmeros aspectos sociais, como é resultado desses aspectos. Ao contrário, apostar no argumento de igualdade, com base na questão biológica, como pressuposto de uma mesma condição feminina, naturaliza diferenças historicamente construídas. Mas qual o significado que essas diferenças adquirem no âmbito da saúde reprodutiva?

SUÁREZ, MACHADO e BANDEIRA (1999: 279) afirmam que

"Gênero, sexualidade e doença são realidades muito diferentes que, não obstante, se igualam na percepção de que, sendo fenômenos sugeridos pela natureza (diferentes de realidades tais como paz, amor e a democracia), dela devem desligar-se para se tornarem realidades construídas, isto é, para chegarem a ter nome e existir, para adquirirem sentido e poder de orientar o desempenho social." 
Isto, também, ocorre com as relações raciais que, a princípio, são do âmbito da natureza, logo, desta se descolam para construírem diferenças e poderes no âmbito de uma dada realidade.

Observa-se que é somente dentro de uma perspectiva relacional, que coloca sob foco a intersubjetividade, ou o confronto de diferentes subjetividades, que podemos apontar para a possibilidade de um campo de articulação entre raça e gênero, que designaria realidades construídas em contextos sociais comuns, e em que comportamentos, atividades e opções, no campo da saúde reprodutiva, configurariam distintos processos de construção social para mulheres negras e brancas.

As subjetividades negras se deparam com realidades bastante adversas para o conjunto da população negra. No que diz respeito, especificamente, à saúde reprodutiva, SOUZA $(1995 ; 2000 ; 2002)$ verificou, ao analisar mulheres negras e brancas, usuárias de um posto de Saúde em São Paulo, maior prevalência de miomas entre mulheres negras: $41,6 \%$, contra $22,9 \%$ entre mulheres brancas, e, reincidência de $21,9 \%$, contra $6 \%$, respectivamente. Ao aprofundar sua análise, verificou que havia um largo desconhecimento quanto ao quadro clínico e conseqüências de se ter um mioma uterino. Sua pesquisa bibliográfica evidencia que estudos americanos sinalizavam para uma maior prevalência de miomas em mulheres negras americanas. SOUZA $(1995 ; 2000 ; 2002)$ verificou, ainda, que, nos casos de miomas em mulheres negras investigadas, estas chegaram, em maior proporção que as mulheres brancas, a uma histerectomia. Isto foi relacionado ao largo desconhecimento do quadro clínico, além de questões associadas às condições de vida.

Colocando sob foco, mais uma vez, as mulheres negras, BATISTA (2002) afirma que elas estão em última posição na escala de valorização social e isso pode intervir, segundo ele, no poder de negociação sexual e uso da camisinha. O direito de escolha do método contraceptivo está 
comprometido por uma percepção esteriotipada da mulher negra, e, com isso, mulheres negras estariam mais vulneráveis ao HIV/Aids. Esta percepção determinaria visões, como aquela apontada por PINTO, BOULOS e ASSIS (2000). Segundo as autoras, existe uma quadrinha popular que diz "Branca é pra casar, mulata é pra fornicar, preta é pra trabalhar". Essa quadrinha foi citada no trabalho de FREIRE (2003). A existência desse tipo de pensamento, na cultura popular, torna difícil não imaginar que o racismo não perpasse a sexualidade e saúde reprodutiva de mulheres negras brasileiras. Neste quadro, a Aids configura-se como um dos fenômenos que põem fim à separação entre o "nós" e os "outros". Pode ser categorizado como um desses fenômenos que, como aponta GIDDENS (1991), pode ter seu risco, no mundo moderno, distribuído desigualmente. Nesse sentido, ter Aids e ser branca tem um significado e um impacto na vida, diferente de ser negra e ter Aids. Isto é o que constata LOPES (2003), que verificou que mulheres negras, portadoras de HIV/Aids, são ainda mais vulneráveis, individualmente, que mulheres não negras. Isto se dá por um conjunto de fatores sociais, como menor acesso à educação formal, condições de moradia e habitação menos favoráveis, baixo rendimento individual e familiar per capita, responsabilidade pelo cuidado, maior número de pessoas, dificuldade de acesso ao teste diagnóstico, dificuldade de acesso às informações sobre terapia anti-retroviral para o recém-nascido e sobre redução de danos no uso de drogas injetáveis, dificuldade em adotar comportamentos protetores, como é o caso do uso de preservativo, entre outros. Além disso, LOPES (2003) aponta fatores de ordem cognitiva, e que contribuíram para o aumento da vulnerabilidade das mulheres negras como, por exemplo, a baixa percepção de risco individual de infecção, associado a outros fatores ligados à dificuldade de acessar um serviço de saúde adequadamente. Ainda, segundo 0 autor, mulheres negras se mostraram menos conscientes da sua condição de soropositivo para o HIV/Aids, entre outras questões. Todo esse quadro mostra a complexidade da realidade das mulheres negras, frente à epidemia da Aids. 
Essas questões servem de subsídios para a movimentação social e política e colocam, em destaque, um sujeito social e político que tem se constituído, na última década, e tem, na articulação de gênero e raça, a base para sua atuação, no âmbito da política. Trata-se da mulher negra.

Relações raciais e saúde reprodutiva, no Brasil, configuram campos teóricos que, na intersecção, visibilizam temáticas importantes e caras às mulheres negras. ROLAND (2001) aponta para essa intersecção, sinalizando para o debate sobre a esterilização cirúrgica no Brasil, entre movimento negro, o emergente movimento de mulheres negras e o movimento feminista. 0 movimento de mulheres negras, nesse cenário, evidenciava uma dada condição, no qual ideologias avessas à liberdade das mulheres negras poderiam ser incorporadas.

\subsection{Saúde em movimento e as mulheres negras}

A reivindicação de políticas que causem impacto na desigualdade racial, no Brasil, colocam, em destaque, o movimento de mulheres negras. Com relação à discussão da questão racial e saúde, circunscrevemos a última década e selecionamos, para apresentação, alguns documentos que deram visibilidade a esta questão e tiveram destaque no cenário político. Foram escolhidos, também, por terem tido uma ampla divulgação e por sacramentarem, de certa forma, um processo político.

- Caderno CEFOR - Introdução do quesito cor no Sistema Municipal de Informação da Saúde, São Paulo, 1992

- Declaração de Itapecerica da Serra das Mulheres Negras Brasileiras, I tapecerica da Serra, 22 de agosto de 1993

- Ministério da Saúde "- Relatório Final: Mesa Redonda sobre a saúde da população negra", Brasília, agosto de 1996 
- Documento da Articulação de Mulheres Negras Brasileiras "Rumo à III Conferência Mundial Contra o Racismo" Rio de Janeiro, 1-3 de setembro de 2000

- Jornal da RedeSaúde. Informativo da Rede Nacional Feminista de Saúde e Direitos Reprodutivos. №22- novembro, 2000

- Jornal da RedeSaúde. Informativo da Rede Nacional Feminista de Saúde e Direitos Reprodutivos. № 23- março 2001

- PNUD/OPAS "Política Nacional de Saúde da População Negra: uma questão de equidade". Workshop Interagencial Saúde da População Negra, realizado em Brasília, nos dias 6 e 7 de dezembro de 2001.

Assim, os documentos listados foram selecionados, por terem circulado amplamente, possibilitando uma divulgação significativa das questões em pauta, atendendo ao critério anteriormente citado. Além de terem um caráter técnico e político, o "Caderno Cefor", o "Relatório Final: Mesa Redonda sobre a saúde da população negra" e o documento "Política Nacional de Saúde da População Negra" são entendidos como respostas às questões sociais e políticas em que o movimento negro e, principalmente, o movimento de mulheres negras, configura-se como ator social importante.

Os dois números do "Jornal da RedeSaúde" reúnem pesquisadores da temática "saúde e raça/cor" e fornecem subsídios para a formulação de propostas de políticas públicas no campo da saúde.

A Declaração de Itapecerica da Serra das Mulheres Negras Brasileiras é a pedra angular para o movimento de mulheres negras. Somado a ela, o documento Articulação de Mulheres Negras Brasileiras "Rumo à III Conferência Mundial Contra o Racismo" constituem documentos centrais para a nossa discussão, dado que pontuam dois momentos sociais e políticos importantes: as Conferências de População em Cairo, 1994, e Contra Racismo, Discriminação, Xenofobias e Intolerâncias Correlatas, em Durban, 2001. 
Da introdução do quesito cor no Sistema Municipal de Informação da Saúde de São Paulo, primeiro município a tomar esta iniciativa, decorre uma década, em que várias outras iniciativas foram tomadas. Esses documentos mapeam a trajetória de uma questão, que desembocou na Conferência Mundial Contra o Racismo, Durban, 2001.

No processo da Conferência Mundial, ocorreram Conferências Regionais em todo mundo. Como destaque, nesse processo, temos a Conferência Regional das Américas Contra o Racismo, que ocorreu no Chile. No documento desta Conferência temos, por exemplo, o parágrafo 111, que requer que a OPAS "promova ações para o reconhecimento da raça/grupo étnico/gênero como variável significante em matéria de saúde e que desenvolva projetos específicos para a prevenção, diagnóstico e tratamento de pessoas de ascendência africana"

A partir desse momento histórico, ganha destaque a " CONFERENCIA REGIONAL DE LAS AMÉRICAS, que passou a ser um documento de referência para a organização, monitoramento, implantação e implementação de ações relativas à população negra e saúde.

Nesse novo contexto, foi realizada 1 a Conferência Municipal de Saúde da População Negra de São Paulo, cujo tema foi "Controle Social e Inclusão Étnico racial".

Mas, o que esses documentos dizem a respeito da saúde da mulher negra? Esses documentos estão dentro das chaves que incluem as categorias gênero e raça. Passemos à análise de alguns deles.

No Caderno Cefor - Introdução do Quesito Cor no Sistema Municipal de Informação da Saúde -, a questão reprodutiva desponta com diferenciais significativos no diagnóstico feito no Município de São Paulo. Esse documento registra o trabalho realizado, formalizado através da portaria 
696/90, posteriormente transformada em projeto de Lei 35/2000, por iniciativa do vereador Carlos Neder.

Os dados apresentados nesse documento revelam que as gestantes, no geral, procuravam o serviço de saúde ao final da gestação, e as grávidas pretas e pardas procuravam bem menos o serviço. Assim, verificou-se, na época de elaboração do documento, que grávidas pardas e pretas, da área de Itaquera-Guaianazes, procuravam bem menos o serviço de saúde no último trimestre, ao contrário do que ocorria no município, onde a procura das mulheres, em geral, no terceiro trimestre, era maior. Isto refletia o quadro de assistência à mulher em idade reprodutiva e gestante, desvelando que a mulher preta e parda procuravam menos o serviço de saúde para 0 seu atendimento ou, na realidade, estavam excluídas do atendimento à saúde no município, em função da forma como os serviços são tradicionalmente organizados.

Em artigo produzido, por ocasião do Seminário Nacional Políticas e Direitos Reprodutivos das Mulheres Negras, do qual saiu a Declaração de I tapecerica, RAMOS E DRUMOND Jr (1993) apontavam para a importância do problema da pressão arterial entre mulheres negras.

A Declaração de Itapecerica (1993:3) já apontava o abuso na esterilização cirúrgica, como um problema de Saúde Pública, e o rápido crescimento da Aids, como resultado da dificuldade de mulheres negras em controlar sua capacidade reprodutiva e sexualidade. Vale lembrar que a Aids já se caracterizava como um grave problema de Saúde Pública para a população negra, na época.

Nesse documento, as mulheres negras concebiam "liberdade reprodutiva como essencial para as etnias discriminadas". Com isto, pretendiam que a reprodução fosse decidida no âmbito do privado, cabendo ao Estado garantir os direitos reprodutivos e assegurar condições para a manutenção da vida. 
Na leitura de ROLAND (2000), o peso político que teve a Declaração de Itapecerica (1993) habilitou as mulheres negras como um sujeito social e político, e permitiu sua inserção em outros espaços. A questão da saúde teve grande importância para o movimento de mulheres negras, desde 0 início. Neste campo, atuavam equipes no Programa de Saúde do Geledes que, posteriormente, fundou a Fala Preta! Organização de Mulheres Negras. Atuavam, também, equipes de pesquisadoras no Programa de Saúde Reprodutiva da Mulher Negra, no CEBRAP (SP) e o Núcleo de Estudos da População (NEPO), da Universidade Estadual de Campinas (UNICAMP).

A saúde é uma questão "humano vital" e o reconhecimento do impacto das desigualdades raciais na saúde da população negra e, em especial, das mulheres negras, é uma problemática que foi politizada desde 0 início.

Dando continuidade ao processo político de visibilização dos agravos à saúde da população negra, é lançado o documento "Política Nacional de Saúde da População Negra"(2001), que aborda temáticas, que vão desde doenças genéticas até doenças de explicações multicausais, como a hipertensão e o mioma. Segundo ele, todas as doenças que afetam a população negra têm, no racismo, um importante fator de agravamento. A hipertensão atinge homens e mulheres, mas se destaca como uma das principais causas de mortalidade materna nessa população. MARTINS (2000), em seu trabalho, mostrou a importância do quesito cor na informação sobre mortalidade materna e o peso da hipertensão como uma das causas.

Os J ornais da REDESAÚDE $(2000 ; 2001)$ dão subsídios para a luta por melhores condições de vida e saúde e para a organização de pautas de reivindicações políticas do movimento de mulheres negras, apresentando dados e informações consistentes sobre a saúde desse grupo populacional. Nesses números, são tratados problemas, como mortalidade materna, 
mortalidade infantil, miomatoses, anemia falciforme, e outras reflexões de importância e interesse para a luta das mulheres negras.

Por se revelarem documentos relativos a movimentos sociais, a questão da relação saúde e raça/etnia, neles apresentada, pode ser colocada na sua dimensão sócio-política. A idéia presente é de que mudanças seriam operadas, não só a partir da ação política, mas também das práticas dos serviços, como, por exemplo, a introdução do quesito cor nas fichas de registros, o que permitiria estudos específicos de natureza comparativa de relevância para a Saúde Pública, em geral, e para a saúde reprodutiva, em especial. Vale mencionar que, embora esteja contemplado em nível dos formulários, tal dado não é coletado de maneira sistemática, o que impede sua utilização e visibilização de diferenças, passíveis de serem encontradas entre mulheres negras e brancas. 0 trabalho de LEAL, GAMA e CUNHA ( $s / d)$, por exemplo, foi capaz de mostrar as desigualdades raciais, sociodemográficas na assistência pré-natal e ao parto, no municipio do Rio de Janeiro, no período de 1999 a 2001. As autoras apresentam uma clara desvantagem, nesse setor, para as mulheres negras, revelando a potencialidade que tem a introdução do quesito cor nas fichas dos serviços de saúde.

A saúde constituiu-se, ao longo de uma década, como uma área, na qual as maiores injustiças são reveladas, tendo em vista, por exemplo, o quadro de saúde apresentado por LEAL, GAMA e CUNHA (s/d), em que mulheres negras recebem um tratamento desigual no atendimento pré-natal e ao parto.

O movimento de mulheres negras, ao longo dessa década, também se solidificou como um sujeito social e político e, no documento da "Articulação das Mulheres Negras Brasileiras: Rumo a III Conferência Mundial Contra o Racismo", além de problemas estruturais, como a pobreza e a miséria a que a mulheres negras estão expostas, são problematizados os fatos de que 0 
mercado de trabalho é altamente injusto para com as mulheres negras e que a naturalização do racismo e do sexismo faz com que as injustiças contra mulheres negras permaneçam invisibilizadas em nossa sociedade. Mais estritamente relacionados à questão da saúde e gênero, aponta a permanência do descaso com as doenças de maior prevalência na população negra, o impacto do racismo na saúde mental, a solidão de mulheres negras, determinada por uma rejeição causada por esteriótipos e a violência contra a mulher, que não respeita fronteiras de raça ou cor, geração e classe social.

De causas genéticas ou multicausais, o impacto do racismo se faz presente, seja na exclusão do atendimento adequado, seja por causas variadas, que levam à maior prevalência de determinadas doenças na população negra, seja porque a população negra está, em grande parte, entre os mais pobres. Todas as origens dos agravos à saúde apresentam a necessidade, pela importância, da informação do quesito cor, como fonte para a formulação de políticas públicas, capazes de promoverem um impacto na desigualdade racial.

Nesse debate emergem, pois, as mulheres negras como um sujeito político de grande participação e sem o qual não seria possível compreender e visibilizar tais questões. Conforme EDNA ROLAND (2000), existem dificuldades para o reconhecimento das mulheres negras, como sujeito político, que precisam ser superadas, para que alcancemos um outro patamar na discussão sobre questão racial e saúde.

Entre elas, estão, em primeiro lugar: as diferenças de concepção sobre o movimento de mulheres negras, a idéia de que a mulher negra é um tema "específico", quer seja do movimento negro, quer seja do movimento de mulheres; em segundo: dificuldades de relacionamento entre as diversas tendências e organizações presentes no movimento; em terceiro, dificuldades de legitimação e validação de lideranças e interferências de outros setores no movimento de mulheres negras. 
Em suma, ROLAND (2000) sinaliza, para reflexão, que tais dificuldades são geradas pelo etnocentrismo e patriarcalismo, que dão origem à idéia de que a questão da mulher negra é uma questão "especifica", quer seja do movimento de mulheres, quer seja dos negros, impedindo que mulheres negras tenham existência própria e autodeterminação, como sujeitos sociais e políticos, representantes de uma parcela significativa das mulheres e da população.

O que o movimento de mulheres negras empreende é uma "luta por reconhecimento" (HONNETH 2003) social e político, importante à sua atividade. Daí, a importância de que o movimento de mulheres negras seja compreendido como um sujeito político e autônomo, e suas reivindicações sejam compreendidas a partir desse foco.

As reivindicações, com relação à saúde, evidenciam a urgência com que essas questões se colocam no nosso cotidiano e como o racismo é, enfim, corporificado e transformado em realidades adversas para mulheres negras.

A saúde reprodutiva de mulheres negras sofre a ingerência de múltiplos fatores, entre os quais, além da questão da raça/etnia, as condições de gênero e de vida que determinam, tanto a possibilidade de maior ou menor autonomia frente ao parceiro, quanto o fenômeno da desigualdade social. Assim, tendo em vista reter as articulações entre gênero e raça no contexto da saúde reprodutiva, procuramos, no presente trabalho, buscar compreender, de um modo geral, a condição da mulher negra, comparando-a com a da mulher branca. A hipótese básica, de que partimos, é que, ao lado da apregoada transversabilidade de gênero, amplamente defendida na literatura especializada, a raça/etnia apresenta-se igualmente como tal nas questões reprodutivas. A seguir, definimos um conjunto de objetivos, tendo em vista melhor explicitarmos o eixo de desenvolvimento do 
processo de investigação junto ao grupo de mulheres negras e brancas, sujeitos da presente pesquisa. 


\section{OBJETIVOS}

- Desvelar relações específicas entre conjugalidade, gênero e raça, no contexto da Saúde Reprodutiva.

- Caracterizar práticas sociais homogêneas e diferenciadas em relação à prevenção da gravidez e do HIV/Aids, na intersecção conjugalidade, relações de gênero e raça.

- Identificar dilemas e contradições nas práticas contraceptivas e na prevenção do HIV/Aids, sob a ótica das relações de gênero e de raça. 


\section{PROCEDIMENTO METODOLÓGICO}

\subsection{Natureza da investigação}

Dada a natureza do problema de investigação delineado, a proposta metodológica contemplou o desenvolvimento de uma pesquisa do tipo qualitativa, que possibilitasse ao investigador desvelar significados estreitamente relacionados ao sentido dado às ações dos sujeitos entrevistados.

Do ponto de vista técnico, a presente proposta apóia-se, por um lado, em pesquisas e documentos divulgados sobre a questão étnico/racial e saúde, na atualidade, tendo em vista a construção do objeto de pesquisa. Por outro, em pesquisa empirica, baseada na "história oral do tipo temática" (MEIHY 1996); isto, porque buscamos reter, no presente trabalho, significados produzidos por sujeitos sociais, no caso, mulheres negras e brancas, vivendo situações que pudessem interferir ou definir escolhas relativas à sua saúde reprodutiva.

\subsection{Referenciais teórico-metodológicos}

A partir dos argumentos de OLIVEIRA (1976) e SAFFIOTI (1992), indagamos sobre a possibilidade de se tomarem etnia/raça e gênero, como formadores de um campo relacional dialético, no qual fosse possível identificar a intersecção entre etnia/raça e gênero na saúde reprodutiva de mulheres negras e brancas e, até mesmo, uma dimensão em que se desvelassem relações de poder, hierarquias e desigualdades.

No campo da saúde reprodutiva, uma certa especificidade característica pode apresentar a etnicidade como uma situação definida, em termos étnicos/raciais; haja vista que, secundarizar o problema gerado pela distinção de raça/etnia (como uma construção social de uma dada diferença) às relações de gênero, pode minimizar a questão da desigualdade. Em 
termos teóricos, as ideologias de gênero, classe e etnia são consideradas materiais, segundo SAFFIOTI (1992), à medida que são modeladas nas experiências e práticas da vida cotidiana. E é no campo ideológico que as identidades étnica (OLIVEIRA 1976) e de gênero (SAFFIOTI 1976) coincidem, na rejeição ou aceitação tácita de igualitarismo e, também, na existência de uma sujeição constatável nas relações que impedem 0 igualitarismo de realizar-se. Então, no bojo dessa intersecção, abre-se um campo de possibilidades em que se apresenta uma dada especificidade e, de acordo com a qual, concepções universalistas são incapazes de explicitar desigualdades sociais vigentes e de mostrar possíveis configurações de sujeição, ou de um processo de "interiorização" de uma dada ordem social, que conforma sujeitos sociais numa dada realidade, como quer SAFFIOTI (1992), citando Michel Foucault.

Da perspectiva do sistema sexo-gênero, como indica SAFFIOTI (1992), modos de expressão de uma dominação social sugerida, esta, também, pelo seu pertencimento racial, desafiam-nos a refletir sobre as diferenças socialmente construídas entre homens e mulheres, sendo que as de raça/etnia desvelam desigualdades estabelecidas, em termos da cor dos indivíduos. A autora afirma, também, que é na subjetivação de um modo específico de "ser" de gênero, que ocorre a sujeição a que se refere OLIVEIRA (1976). O gênero, define SAFFIOTI (1992:189), "é uma maneira contemporânea de organizar normas culturais, passadas e futuras, um modo de a pessoa situar-se e através destas normas, um estilo ativo de viver o corpo no mundo". Deste ponto de vista é que a construção de SCOTT (1991) apresenta interesse para o presente trabalho, à medida que ela organiza 0 conceito de gênero de uma perspectiva em que é possível a compreensão das relações de poder. Segundo Foucault, citado por SAFFIOTI 1976), o poder é útil ao propor um dispositivo construtor de realidades perceptíveis, muito mais em nível micro, do que em nível macro. 


\subsubsection{Gênero}

Gênero, como categoria analítica, pretende distinguir práticas sexuais, de papéis sexuais atribuídos às mulheres e aos homens e é, além disso, uma maneira de indicar as construções sociais que estão por trás dos ditos papéis masculinos e femininos (SAFFIOTI 1976; SCOTT 1991)

Apresentando-se como objeto e, também, como campo de estudos, o gênero tem apresentado uma diversidade de abordagens, que tem enriquecido o debate sobre questões pertinentes a esse tema. Neste sentido, destacam-se, por um lado, os estudos pós-estruturalistas, ou culturalistas, e, por outro, os estudos neomarxistas que àqueles, muitas vezes, se contrapõem. Uma das discussões travadas trata da idéia de transversalidade, defendida pela postura pós-estruturalista, e minimizada pela abordagem neomarxista, para a qual a determinação de classe é predominante, muito embora reconheça as mediações do gênero e da raça na abordagem das questões sociais.

Para SAFFIOTI (1992: 185), por exemplo, a transversalidade se dá em relação ao poder, como este é constituído e partilhado socialmente. Para essa autora, as relações de gênero travam-se em terrenos do poder em que "há exploração dos subordinados e a dominação dos explorados, dominação e exploração, sendo faces de um mesmo fenômeno". O conceito que emprega está intimamente relacionado à classe social. As concepções de gênero, por sua vez, representam a ruptura com o pensamento de sexo, como destino.

Para SCOTT (1991), os conceitos de poder, nem sempre, referem-se diretamente ao gênero, em si mesmo, ainda que reforcem distinções de gênero. É uma categoria imposta ao corpo sexuado, no seguinte sentido: destaca o sistema de relações que pode incluir o sexo, mas não é determinado pelo sexo, nem determina diretamente a sexualidade. Para ela, gênero é uma primeira instância, um primeiro campo, no interior do qual o 
poder é articulado, e não o único (1991: 17). Ela ainda deduz, da teoria elaborada por Bourdieu, que

“...estabelecido um conjunto objetivo de referências, o conceito de gênero estrutura a percepção e a organização concreta e simbólica de toda vida social. À medida que essas referências estabelecem distribuições de poder (um controle ou um acesso diferencial aos recursos materiais e simbólicos), o gênero torna-se implicado na concepção e na construção do poder em si."

\subsubsection{Etnia, etnicidade, raça}

A questão racial se funda na reflexão sobre a diferença. Nesse sentido, JACQUARD (1998) assevera que a distância (genética mesmo) entre um homem de pele bem escura e um homem de pele clara pode ser bem inferior do que aquela que separa dois homens de pele clara. Essa evidência, segundo o autor, coloca em cheque o critério de classificação racial, que separa os homens entre brancos e negros, amarelos e vermelhos. Em cima desse critério estabeleceu-se o que STEPHEN JAY GOULD (1991) denominou de "falsa medida do homem". Através desta estratégia de medida racial, estabeleceu-se uma falsa ciência que justificava a superioridade e inferioridade dos homens. A certeza da inferioridade de certos grupos humanos justificou a escravidão. A própria constatação de desigualdade tinha, por detrás, a idéia naturalizada de raça. Um exemplo disso são os estudos de OLIVEIRA VIANA (1991), que afirmam a inferioridade, inclusive psicológica, dos negros em relação aos brancos. 0 embranquecimento estava colocado como única saída para a população brasileira. Foi contra esse pensamento que se fazia hegemônico, no Brasil, que GILBERTO FREIRE (2003) desenhou sua tese da morenidade. Por esta epistola, Freire contrapunha-se à tese dos erráticos Oliveira Viana e Nina Rodrigues, que 
depositavam na raça a elucidação para a tese de desigualdade naturalizada. FREIRE (2003), fundado na antropologia de Boas, vê na cultura a base explicativa para a diferença. Sem se desprender totalmente das teorias biologizantes, coloca na mestiçagem uma relevância maior para a construção da brasilidade e constrói a sua tese de democracia racial. Segundo GUIMARÃES (1995:38), seria "um erro pensar que o pensamento antropológico do meado deste século - seguindo os passos de Freire mudou radicalmente os pressupostos racistas da idéia de embranquecimento. Na verdade, a tese do embranquecimento foi apenas adaptada aos cânones da Antropologia Social, passando a significar a mobilidade ascensional dos mestiços na hierarquia social".

A chamada Escola Paulista de Sociologia, mais especificamente, Florestan Fernandes, questionou o conceito de democracia racial, postulado por Gilberto Freire, e passou a referir-se a ela como "mito". Florestan Fernandes, ao refletir sobre a problemática racial, chamava a atenção à herança do passado escravista, que impossibilitava aos negros estarem integralmente inseridos na sociedade de classe. Aprofundando a questão, Nelson do VALLE SILVA (1998), bem como HASENBALG (1998), consideram que os problemas sofridos pelos negros são bem atuais, e não somente reminiscência de um passado escravista.

O conceito de raça, segundo MUNANGA (1990), tem, historicamente, desembocado em uma classificação que a própria biologia, pelo menos a atual, contesta, tendo em vista os critérios que são utilizados, considerados sem valor científico. Um dos critérios elencados pelo autor é a cor da pele que, sugerida pela natureza, leva ao que se chama, até hoje, de raça branca, amarela e negra, como atesta J ACQUARD (1998).

O conceito de raça, destituído de seu caráter biológico, apresenta-se como uma construção das relações raciais. No caso específico do Brasil, raça emerge atravessada pelo mito da democracia racial e pelo ideal de 
branqueamento da população negra. Autores, como MUNANGA (1996; 1998;2002) e SCHWARCZ (1998), problematizam a questão racial no Brasil.

Enquanto a identidade negra guarda, em si, um sentido político ideológico, à medida que se filia ao pensamento sobre a negritude, como forma de consciência, que permite ao negro lutar contra a alienação e contra a inferioridade imposta nas relações sociais, a identidade mestiça guarda, em si, um biologismo politizado, porque parte da concepção de duas raças se misturando (o sangue branco e o sangue negro), para a formação da identidade mestiça (MUNANGA 2001)

A visão psicanalítica de Jurandir Costa FREIRE (1986) permite pensar o racismo como um fenômeno social, mas a partir do indivíduo negro. Como o racismo repercute, por meio da violência nas vidas de homens e mulheres negros, destrói o sujeito negro e constrói a inferioridade frente ao ego branco. Os mecanismos psicanalíticos que levam a tal processo são desvendados, por esse autor, que atribui ao racismo a capacidade de fazer 0 sujeito negro recusar-se violentamente e desejar o branqueamento.

Raça é uma dimensão das relações sociais, na qual colocam-se definições de pertencimento racial, que vão configurar distintos grupos étnicos, habitualmente expressos em termos de caracteres fenotípicos. Com relação a esta questão, IANNI (1996: 8) coloca que

“Etnia' é o conceito científico habitualmente utilizado para distinguir os indivíduos de outras coletividades por suas características fenotípicas, ao passo que 'raça' é o conceito cientifico elaborado pela reflexão sobre a dinâmica das relações sociais, quando se manifestam estereótipos, intolerâncias, discriminações, segregações ou ideologias raciais. São os indivíduos, grupos ou coletividades, que definem reciprocamente como pertencentes a 'raças' distintas." 
No campo da Antropologia, etnia é um qualificador de grupo étnico ou minoritário, ao passo que a concepção de etnicidade, mais abrangente, segundo OLIVEIRA (1976), revela o espaço relacional em que se constituíram as identidades. Ainda segundo esse autor, os analistas tendem a

"usar etnicidade quer como uma categoria estrutural, isto é, como um princípio geral que ilumina o comportamento, ou como um fenômeno cultural, isto é, como um conjunto de atitudes, crenças e estereótipos que o povo sustenta sobre pessoas identificadas por algum 'rótulo' étnico apropriado"(OLIVEI RA1976: 86).

Esses "rótulos" podem ser compreendidos como ícones (sinais diacríticos) que indicam a discriminação ou o estabelecimento de relações hierárquicas e desiguais. Com base em PINTO (2000), pode-se supor que, assim como o gênero, a etnicidade pode moldar as estruturas das percepções, organizar a vida social e estabelecer configurações e constituir relações, em que o poder é hierarquicamente distribuído, além de desvelar modos de dominação social e simbólica.

Para OLIVEIRA (1976), é importante diferenciar a construção do conceito de etnicidade, presente em nível da linguagem simbólica do "senso comum", da construção da linguagem científica do etnógrafo. Segundo o mesmo autor, a etnicidade é definida como uma construção do senso comum, que torna "inteligível aos observadores a ação dos sujeitos". 0 autor estabelece uma reflexão entre o "vivido" e o "conhecido" para conceber a idéia de que as decisões, nem sempre, procedem de uma ação consciente dos valores implicados no agir. A linguagem discursiva dos agentes é o meio pelo qual o analista, no caso etnógrafo, desvenda a estrutura, tendo, nos aspectos interétnicos, a dimensão relacional da etnicidade. Este princípio rompe com a idéia de uma sociedade transparente aos seus agentes, 
constituindo, portanto, um campo socioantropológico, no qual o princípio do não-consciente não se confunde com a noção psicanalítica de inconsciente.

Em termos analíticos, OLIVEIRA (1976) entende, como necessário, diferenciar os conceitos de etnicidade, como conceito estrutural, e de etnia, como conceito cultural. É em relação ao conceito de etnicidade que hierarquias, subordinação e exclusão social podem ser melhor apreendidas. Neste sentido, etnia circunscreve-se aos sinais de pertencimento étnico, como cabelo, cor de pele, atitudes culturais, que formam as construções do senso comum.

No sentido social, a problemática racial se revela sob a idéia de que vivemos em um país que tem "preconceito de ter preconceito" (SCHWARCZ 1998). De um ponto de vista interpretativo, o conceito de raça amplia 0 processo de discussão sobre o tema. De acordo com MUNANGA (2002), o conceito de "etnia" diz respeito ao conteúdo cultural de um grupo, e o de "etnicidade", que se coloca em termos de "rótulos" e "estereotipias" que surgem na hierarquização ou dominação de um grupo, são limitados, pois não apreendem as possibilidades de transformação de uma dada realidade, que se caracteriza pela subordinação ou de dominação social.

Tendo em vista esses conceitos, como depreender as relações raciais que envolvem negros e brancos no Brasil?

Na leitura de WOOD (1991: 93), a "percepção da condição racial" tem uma base multidimensional e "sugere a possibilidade de que um indivíduo, que tenha experimentado ascensão social e se classificado como preto ou pardo, em certa época, possa identificar-se como pardo ou branco, posteriormente". Raça é uma construção social, não um dado biológico.

Do ponto de vista empírico, observa-se que a classificação racial é uma construção a partir da percepção individual e coletiva com relação à cor e revela parâmetros que definem uma cor e outra, não sendo fixos e nem 
pautados, necessariamente, por atributos biológicos, mas captam, no entanto, a cor da pele para a designação de um segmento populacional e outro. Podem ser tomados em um quadro de referências socioculturais como característico de segmentos da população (WOOD 1991) e é desta perspectiva que pretendemos reter a problemática racial no âmbito da saúde reprodutiva e pensar, talvez, na etnicidade ou racialização do gênero, visibilizando, assim, mais uma dimensão das relações sociais.

Assim sendo, tomar o conceito de raça permitiu colocar a questão sob um prisma mais amplo, na medida em que, na concepção de IANNI (1996), seria possível contemplar aspectos étnico-raciais em uma totalidade de relações sociais.

\subsection{Processo de coleta de dados}

A coleta de dados comportou duas fases: a coleta de materiais impressos, documental, sobre a luta das mulheres negras e a pesquisa de campo. A pesquisa de campo, intitulada "Genero e raça: intersecções no campo da Saúde Reprodutiva" é parte de um projeto temático mais amplo, desenvolvido no Departamento de Saúde Materno - Infantil da Faculdade de Saúde Pública da Universidade de São Paulo, que versa sobre Saúde Reprodutiva e Sexual e a questão da transversalidade de gênero, raça e classe.

Os documentos impressos estão referidos na introdução deste trabalho, mais precisamente no item 2.1 - Saúde em movimento e mulheres negras, que trata do processo de construção do objeto da pesquisa. Não houve uma distinção entre esse material e as referências bibliográficas, propriamente ditas. Os documentos, também, serviram de referências bibliográficas, como por exemplo, o "Caderno Cefor". É, ao mesmo tempo, um relatório do processo de introdução do Quesito Cor no Sistema Municipal 
de Saúde, e um exemplo de como a militância negra está organizada no âmbito do município, o que aponta para a importância da articulação entre trabalho técnico e político.

Essa articulação ficou suficientemente clara no processo de construção da $1^{\text {a }}$ Conferência Municipal de Saúde da População Negra: Controle Social e Inclusão Étnico/Racial em São Paulo. Intelectuais negros(as) e técnicos da Prefeitura da cidade de São Paulo trabalharam para a realização da conferência, além de segmentos da sociedade civil, do qual fizemos parte. Não existia um limite claro para as duas atividades, uma vez que ativistas políticos, também, eram pesquisadores e/ou trabalhadores/técnicos. Deste modo, incluímos, na referência geral, trabalhos que foram, de alguma forma, referência para a presente investigação, dado o conteúdo veiculado.

\subsection{Sujeitos sociais da pesquisa empírica}

Os sujeitos sociais da pesquisa foram mulheres em situação de união conjugal, classificadas, de acordo com o critério censitário do IBGE, como negras (as pretas e pardas) e brancas.

As mulheres foram selecionadas a partir da técnica denominada "Bola de Neve" (PATTON 1990). Esta técnica consiste em identificar indivíduos que atendam aos critérios de inclusão e de exclusão, pré-estabelecidos pelo pesquisador. A pessoa é convidada a participar da pesquisa e solicita-se que indique uma outra pessoa em condições semelhantes e, assim, sucessivamente, de modo que se constituiu a "casuística", considerada adequada aos objetivos da pesquisa.

Quando não se conseguia a indicação, partia-se para um novo contato na rede de relações. As mulheres foram contatadas a partir do circulo de relações pessoais de 3 pesquisadoras: a autora da tese e duas pequisadoras qualificadas para o trabalho. 
Quanto aos critérios de inclusão das mulheres, definiram-se, basicamente, dois:

- autoclassificar-se como negra (preta, parda) ou branca;

- estar vivendo (maritalmente) uma relação conjugal, no mínimo de um ano.

Foram entrevistadas 36 mulheres, conforme quadro que segue:

Quadro 2 - Distribuição das mulheres participantes do estudo, por cor e escolaridade

\begin{tabular}{|c|c|c|c|}
\hline & NEGRAS & BRANCAS & TOTAL \\
\hline SUPERIOR & 6 & 6 & 12 \\
\hline MÉDIO & 6 & 6 & 12 \\
\hline FUNDAMENTAL & 6 & 6 & 12 \\
\hline TOTAL & 18 & 18 & 36 \\
\hline
\end{tabular}

O trabalho de campo durou, aproximadamente, seis meses, e consistiu na realização de entrevistas, com utilização de dois instrumentos: um formulário semi-estruturado (Anexo I), para caracterização socioeconômica e obtenção da história reprodutiva das mulheres selecionadas; e um roteiro temático, para entrevista em profundidade (Anexo II). É interessante destacar que, em função da técnica utilizada - bola de neve - para seleção da população de estudo, esta se caracterizou por ser constituída por mulheres que têm uma atividade profissional, em sua maioria. São mulheres que trabalham. Outra questão a ser destacada refere- 
se ao critério etário de inclusão - mulheres entre 25 anos e 49 anos de idade - que limitou os resultados, no que diz respeito a evidências quanto ao caráter geracional. Maiores detalhes sobre o grupo estão descritos no capitulo 5, em que buscamos caracterizar as entrevistadas. É interessante ressaltar que os dados utilizados, obtidos mediante entrevistas, seguem uma organização que possibilita uma compreensão, mais temática do que biográfica, do conteúdo das entrevistas.

4.5 Técnica de tratamento para análise dos discursos dos sujeitos da pesquisa

$\mathrm{Na}$ diversidade de estratégias para se pensar a construção de sentidos postulados no cotidiano, as análises, no campo das ciências humanas, estabelecem como base a linguagem do senso comum. Do ponto de vista da perspectiva psicossocial, a produção de sentido não é considerada uma "atividade cognitiva intra-individual" (SPINK 1999: 42), mas sim uma prática social dialógica, que tem por base a linguagem em uso. Trata-se, portanto, de um fenômeno sociolingüístico, por se referir a uma linguagem que subsidia as práticas sociais que geram sentidos. As práticas discursivas, ou linguagem em ação, são momentos de "ressignificações, de ruptura, de produção de sentidos, ou seja, correspondem aos momentos ativos do uso da linguagem, nos quais convivem, tanto a ordem, como a diversidade" (SPINK 1999: 45).

Seguindo recomendações de MINAYO (1996), organizamos o processo de análise em diferentes fases, sendo a primeira caracterizada por três aspectos, a destacar:

a) "Constituição do corpus": os conteúdos levantados pelo roteiro de entrevista devem satisfazer o critério de "exaustividade". MINAYO (1996) afirma que o material deve conter os pontos inquiridos no 
roteiro, ser representativo do universo pesquisado e pertinente aos objetivos do trabalho, além de ser homogêneo.

b) "Leitura flutuante": consiste em uma leitura exaustiva do material coletado, tendo em vista a identificação do conteúdo presente nas falas.

c) "Significado das hipóteses": as hipóteses iniciais, em um trabalho qualitativo, segundo MINAYO (1996:95), "perdem a sua dinâmica formal comprobatória para servir de caminho e de baliza no confronto com a realidade empírica". Nesse sentido, a fase anterior, préanalítica, determina a unidade de contexto para a compreensão da unidade de registro (palavra-chave), além dos recortes, forma de categorização, a modalidade de codificação e os conceitos teóricos mais gerais para orientação da análise".

No processo de aprofundamento da análise das falas, outros passos se apresentam, quais sejam:

a) A definição de categorias específicas, a partir da articulação de palavras-chave com significados similares ou aproximados, passíveis de se constituírem em elementos de análise significativas dos discursos empíricos identificados.

b) A definição de categorias gerais, ou núcleos de sentido, a partir da articulação, ou não, das categorias específicas identificadas empiricamente. Tais categorias, ou núcleos, constituirão a estrutura interna do discurso da investigadora a ser elaborado sobre as falas dos sujeitos entrevistados.

Em relação ao tratamento dos dados foram realizadas transcrições das entrevistas, e os dados processados no Ethnograph v.5 (SEIDEL 1998), programa para pesquisas qualitativas. 


\subsection{Categorias de análise}

Os conteúdos das falas e demais resultados foram organizados a partir de um conjunto de núcleos estruturadores do texto monográfico, relacionados às categorias gerais e específicas, que constam do índice analítico apresentado no início do trabalho. 


\section{CARACTERIZAÇÃO DAS ENTREVISTADAS}

O presente capítulo fornece ao leitor uma caracterização de cada um dos sujeitos da pesquisa, apresentada em categorias, segundo cor e escolaridade, tendo em vista oferecer um contexto para a leitura das falas, apresentadas nos capítulos posteriores.

Em anexo, o leitor pode contar, igualmente, com uma caracterização, em forma de um conjunto de quadros, com o objetivo de complementar informações que ilustrem as falas das mulheres pesquisadas (ANEXO V)

Mulheres Negras, de escolaridade superior

1. Luci, professora, 27 anos, negra (preta). Nasceu em São Paulo. Não está estudando no momento. Concluiu o ensino superior. Trabalha como professora do ensino fundamental. Além do trabalho, desenvolve atividade complementar como digitadora. É casada há dois anos e dois meses. Seu marido é negro. Para evitar gravidez, o marido usa camisinha. Não tem filhos e teve um aborto provocado. Não gosta de usar camisinha. Usa, porque não se adaptou aos comprimidos anticoncepcionais. Tentou usar a camisinha feminina, mas também não se adaptou.

2. Regina, socióloga, 39 anos, negra ( parda). Nasceu em São Caetano do Sul, mora em São Paulo há 30 anos. Não está estudando no momento. Terminou o mestrado e está sem trabalho fixo, no momento. Faz trabalhos de pesquisa e dá aulas esporadicamente. Vive em união livre há 5 anos. Seu marido é moreno claro ( branco). Para prevenir a gravidez, marido usa preservativo, não tem filhos e teve um aborto provocado. Ela passa mal com a pílula, tem dor de cabeça, mal estar e é fumante. Usa a camisinha, por considerá-la mais prática e não causar alterações: não incha as pernas, segundo ela. 
3. Roberta, cientista social, tem 41 anos, negra (parda). Nasceu em São Paulo, vive em trânsito, entre São Paulo e Maringá (PR). Está fazendo testes para ingressar na pós graduação em Antropologia. No momento, não está trabalhando. É casada, no civil, há 16 anos. Seu marido é moreno claro (branco). Para previnir gravidez, marido usa preservativo. Tem dois filhos. Adaptou-se ao uso da camisinha e não gosta de tomar pílulas.

4. Luísa, médica cardiologista, 33 anos, é negra (preta). Nasceu em Belo Horizonte (MG). Mora há 2 anos em São Paulo. Está cursando pós graduação. É casada há dois anos, no civil e no religioso. Seu marido é negro. Para prevenir gravidez, marido usa o preservativo. Tem problema de mioma uterino e teve que tirar o DIU. Não tem filhos. Prefere o DIU, pela tranqüilidade, mas é contra-indicado para quem não teve filhos e por causa do mioma. A tabelinha a deixa insegura. A pílula causa varizes, então, optaram pelo uso da camisinha.

5. Hortênsia, professora de história e assistente de projeto em uma ONG, tem 41 anos, é negra (preta). Nasceu em São Paulo. Vive em união livre há 16 anos. Seu marido é negro (pardo). Para prevenir gravidez, ela fez laqueadura. Tem quatro filhos e teve um aborto provocado, com o uso de ervas, ensinado pela mãe. Optou pela laqueadura, teve os filhos que desejava e não queria ficar grávida novamente, em hipótese nenhuma, e a camisinha era um problema, pois havia sempre o dia em que não usavam .

6. Marta, advogada, tem 44 anos. Nasceu em Ouro Verde (SP), mora em SP há 25 anos, é negra (preta). Vive em união livre, há 3 anos. Seu marido é negro (pardo). Para prevenir gravidez, recorrem ao coito interrompido. Não tem filhos e teve um aborto provocado. A pílula, ela não pode, porque é fumante e já tem idade avançada. Diz que não escolheu 0 coito interrompido, mas acabou sendo este, devido ao momento. Perceberam que dava certo e se acostumaram. 
Mulheres negras de escolaridade Média

1.Vânia, segundo grau, ajudante em uma oficina de costura, tem 26 anos, nasceu em Santa Helena, no Paraná, mora há 26 anos em São Paulo. É negra (parda). Seu marido é branco. Tem um filho. Usa anticoncepcional injetável para evitar filhos. Não teve nenhum aborto. Preferiu 0 anticoncepcional injetável, porque é somente uma vez por mês. A camisinha, segundo ela, é ruim, incomoda, e com o comprimido, ela passa mal. 0 anticoncepcional injetável é fácil de controlar, porque é somente uma vez por mês. E não se sente mal.

2. Maria Célia, segundo grau, bancária, tem 41 anos. Nasceu em São Paulo. É negra (parda). Casada há 12 anos, seu marido é branco. É laqueada. Teve dois filhos e dois abortos espontâneos. A pílula a fazia passar mal e é alérgica a qualquer tipo de borracha.

3.Maria Wilma, segundo grau, é costureira, trabalha por conta própria, tem 41 anos. Nasceu em Londrina, no Paraná, está há 30 anos em São Paulo (capital). É negra (parda). 0 marido é negro. Tem dois filhos gêmeos e teve um aborto espontâneo. Para evitar filhos, usava pílula e está grávida, no momento. A pílula, na opinião dela, é o método mais seguro, mas chega uma idade em quel tem-se que parar com a pílula, porque faz mal. Usou a pílula durante 11 anos. A camisinha, ela acha desconfortável, mas já usou a tabelinha junto com o preservativo, até que falhou.

4.Marina tem segundo grau e era vendedora, tem 31 anos de idade. Nasceu em Itabuna (BA) e mora em São Paulo há 24 anos, é negra (parda). É casada há 10 anos. Seu marido foi classificado como moreno. Para prevenir gravidez, não está usando nenhum método, atualmente.Tem uma filha e teve um aborto espontâneo. Não suporta a camisinha e com 0 anticoncepcional fica enjoada e nervosa. Ela estranha a camisinha, apesar de considerar que é o método mais higiênico. 
5.Ana tem segundo grau, auxiliar de enfermagem. Tem 46 anos de idade. É negra (preta). É casada há 19 anos. Seu marido é negro. Para prevenir gravidez, fez laqueadura. Não sabe explicar porque se laqueou. Considera que foi por falta de informação.

6. Amanda, 48 anos, tem segundo grau, está desempregada e faz salgados, em geral, para complementar a renda. É negra (preta). É casada há 15 anos. Seu marido é negro. É histerectomizada. Tem uma filha e teve três abortos espontâneos e um provocado. Não se adaptava à pílula, porque a fazia passar mal e a camisinha incomodava muito.

Mulheres negras, de escolaridade fundamental

1.Regiane, série primária, 48 anos. Trabalhou em fábrica de doces e de bexigas, como ajudante. É negra (preta). Nasceu em São Paulo. É casada há 25 anos. Seu marido é negro. Tem três filhos. Considera a camisinha como um método confortável, além de evitar a transmissão de doenças sexualmente transmissíveis. A pílula a fazia passar mal. Acabou optando pela laqueadura.

2.Eliane fez até a $6^{\mathrm{a}}$ série do ensino fundamental. Tem 30 anos. Trabalha informalmente, faz crochê. Nasceu em Irecê, na Bahia. É negra (parda). É casada há 16 anos. Tem três filhos. É laqueada e, atualmente, usa camisinha, também, com seu marido, por desconfiar de sua fidelidade. Preferiu a laqueadura, porque corre risco de vida na hora do parto.

3.Dalila tem a 4ạ serie do 10 grau. Tem 33 anos. Não está trabalhando atualmente. Foi ajudante geral em uma fábrica. É negra (parda). É casada há 16 anos. Seu marido é negro (pardo). Para evitar gravidez, usa normalmente a pílula, mas parou uns meses (cinco) para descansar. Tem dois filhos. Adaptou-se ao uso da pílula. 
4.Pámela tem 10 grau. É auxiliar de enfermagem. Tem 42 anos. É negra (parda). É casada há 18 anos. Seu marido é negro. Para evitar gravidez, ela fez laqueadura. Tem dois filhos. Teve um aborto espontâneo, provocado por um acidente. Com a laqueadura, não tem alteração fisiológica nenhuma. Durante 14 anos, tomou pílula e sentia dor de cabeça.

5.Sabrina tem a $5^{\text {a }}$ série do 10 grau. Tem 27 anos. É negra (parda). Nasceu em Aracaju (SE). Não trabalha atualmente, mas já trabalhou, como auxiliar de limpeza e doméstica. É casada há 7 anos. Seu marido é branco. Tem três filhos e teve um aborto espontâneo. Para evitar gravidez, não usa nada, não fez só a laqueadura, explica que extraiu as trompas. Não se adaptou ao uso da camisinha.

6. Rosana, 35 anos, $5^{\text {a }}$ série do 10 grau. Não está trabalhando, no momento. Já trabalhou como ajudante geral. Tem 35 anos. Nasceu em Santo André (SP). Mora em São Paulo há 34 anos. É negra (parda). É casada há 16 anos e, para evitar gravidez, fez laqueadura, para não ter mais perigo de ter filhos. Tem três filhos.

Mulheres Brancas, de escolaridade Superior

1.J uçara é socióloga e professora, branca, tem 29 anos. Seu marido é branco Nasceu em São Paulo. É casada há dois anos. Não tem filhos. Marido usa camisinha para evitar filhos. Nunca engravidou. Considera a camisinha prática e porque não quer tomar hormônio. A camisinha, segundo ela, é mais natural e sempre foi consensual com os parceiros. Tomar hormônios, em geral, causa-Ihe enxaquecas.

2. Sonia, psicóloga, 35 anos. Nasceu em São Paulo, capital. É branca. É casada há 15 anos. Seu marido é branco. Tem um filho e teve um aborto provocado. Para evitar gravidez, seu marido fez vasectomia. Escolheu este 
método, porque ele não gera nenhuma restrição para a vida sexual e não quer ficar se preocupando com o método anticoncepcional.

3.Suzana, 37 anos, nasceu em São Paulo, capital. É branca e seu marido, amarelo. É casada há seis anos. É escriturária. Tem duas filhas e para evitar gravidez, marido usa camisinha, por achar mais cômodo e prático.

4.Sara, 37 anos, nasceu em São Paulo, capital. É branca e seu marido é branco. É professora de escola técnica e Faculdade do Estado. É casada há 1lanos. Teve três filhos, um faleceu aos 9 anos, foi atropelado. Para evitar gravidez, usa tabelinha, porque percebe a evolução do seu ciclo reprodutivo. Tem o ovário policístico, o que leva, segundo ela, a menstruar sem ovulação. O marido, segundo ela, tem grande quantidade de espermatozóides, porém só metade maduros, causado pelo trabalho, stress, bebidas, cigarro e uso de drogas na adolescência.

5.Solimar, socióloga, empresária. Tem 40 anos. Nasceu em São Paulo, capital. É branca. É casada há 14 anos. Não tem filhos, teve dois abortos, um espontâneo e um provocado. Para evitar gravidez, marido usa preservativo. Não toma pílula, porque é fumante e isso provoca, segundo ela, efeitos colaterais fortes, com o DIU teve hemorragias fortes e dói para pôr e para tirar. Além de esses dois métodos pílula, DIU) não prevenirem doenças sexualmente transmissíveis. A camisinha feminina é pouco anatômica e, com a masculina, a responsabilidade da contracepção fica compartilhada com o homem.

6.Suzete, historiadora. Tem 41 anos. Nasceu em Sete Lagoas (MG), está em São Paulo há dois anos. É branca. Seu marido é classificado como branco. É casada há 10 anos. Tem um filho. Para evitar gravidez, usa atualmente 0 DIU. Teve 3 abortos provocados. Deixou de usar a pílula, porque era fumante e associava às varizes na família, além de ser meio "natureba", avaliava que não devia tomar hormônio. Não gosta da pílula. Com o diafragma, não sentiu confiança, todo mês tinha medo de estar grávida. Com 
o DIU, não tem medo de estar grávida. Faz preventivo todo ano, avaliação do DIU, para ver sua posição. Tem confiança nesse método.

Mulheres brancas, de escolaridade Média

1. Cris nasceu em São Paulo, tem 25 anos. Foi telefonista, antes de parar de trabalhar. Tem o segundo grau completo. É branca e seu marido é branco. Parou de trabalhar na gravidez do primeiro filho, por problemas de saúde. Tem dois filhos. No momento da pesquisa, estava fazendo tratamento ginecológico.

2. Teresa nasceu em Condeuba, na Bahia. Está há 14 anos em São Paulo (Capital). Tem 36 anos. É branca. Tem segundo grau completo. É auxiliar de enfermagem. Está casada há 14 anos. Seu marido é branco. Tem duas filhas, e seu marido fez vasectomia. No momento em que havia resolvido fazer laqueadura, o marido resolveu fazer a vasectomia.

3. Carla, 35 anos, nasceu em São Paulo, capital. É branca. Seu marido é branco. Não tem trabalho fixo, trabalha informalmente, como decoradora. Tem dois filhos e seu marido é vasectomizado. Ela gosta da vasectomia, porque fica mais tranqüila. Considera que a laqueadura engorda a mulher, deixa-a mais nervosa e traz conseqüências para a saúde ginecológica, dependendo da idade da mulher, não é indicado. Como ela teve o segundo filho com 21 anos, não poderia fazer a cirurgia para a laqueadura. Ela e 0 marido combinaram: ela já tinha tido dor nos dois partos e não podia tomar comprimidos. Ele teria que fazer alguma coisa. Optaram pela vasectomia, pois o uso freqüente da camisinha não agradava ao casal.

4. J oana nasceu em Belo Horizonte (MG). Vive em São Paulo (Capital) há 38 anos. É branca e o marido é negro. Não tem trabalho fixo. É síndica e faz free-lancer de editoração e diagramação. Não tem filhos. Teve dois abortos e, atualmente, o marido usa camisinha para evitar a gravidez, porque está 
em tratamento e não definiu o método definitivo. Tem duas opções: o DIU ou Diafragma. Usou o DIU por mais de cinco anos. Este método causava dor e quando tirou, estava com inflamação no colo do útero. Após retirar o DIU, engravidou e teve aborto espontâneo. O DIU, de acordo com o quadro clinico, é uma imposição médica. Não vê a tabelinha como eficiente e não considera como um método anticoncepcional. Foi sugerido o diafragma, na versão que pode ficar mais tempo no corpo da mulher, mas ainda não 0 colocou, por estar em tratamento.

5. Amalia tem 39 anos, nasceu em Santo André (SP), vive em São Paulo (Capital) há 6 anos. É branca e o marido, classificado como branco. É assistente administrativo. É casada há 11 anos. Tem um filho. Seu marido é vasectomizado. Quem escolheu o método foi o companheiro. Já tinha um filho do primeiro casamento e, com o segundo filho, considerou que já era suficiente. Como só tem o marido como parceiro sexual, não corre risco de gravidez. Teve diabetes gestacional na primeira gravidez e um segundo filho corre o risco de já nascer diabético.

6. Gilmara nasceu em Santo André. Tem 27 anos. É branca. Seu marido é negro (pardo). Trabalhou como vendedora na C\&A. Tem o segundo grau completo. Marido usa preservativo, para a prevenção da gravidez, mas não gosta, porque, segunda ela, incomoda. Está usando este método porque teve que parar a pílula por um mês.

Mulheres brancas, com escolaridade fundamental

1. Lucia tem 38 anos, nasceu em São Paulo (Capital). É branca, promotora de vendas. Tem o primeiro grau completo. É casada há 15 anos e 8 meses. Seu marido é branco. Tem três filhos biológicos e uma, adotiva. Seu marido é vasectomizado. Tiveram três filhos e consideraram o número suficiente. Não era viável ter mais um filho. A vasectomia deu tranqüilidade, além de 
ser mais cômoda, segunda ela. O coito interrompido sempre deixa a preocupação, o DIU, nunca teve condições financeiras de colocar.

2.Mary, 46 anos, nasceu em São Paulo (Capital). É branca. Seu marido é classificado como moreno. Tem o primeiro grau completo. Trabalha como auxiliar de importação e exportação na firma, em que é sócia do marido. É casada há 15 anos. Tem um filho biológico e uma adotiva. Não usa nada como contraceptivo, pois tem problemas de hormônio e não engravida com facilidade. Teve uma gravidez e já tinha essa deficiência hormonal e não sabia, ficava muito desgastada, os espermatozóides não conseguiam chegar vivos. O DIU, ela considera que acarreta problemas de inflamação e infecção. A pílula, avalia que é mais prática, apesar do problema do esquecimento.

3.Gorete, 41 anos. Nasceu em São Paulo (Capital). É branca. Tem primeiro grau completo. O marido é branco. Trabalha como auxiliar de limpeza. Tem 22 anos de casada. Teve quatro filhos, sendo que três estão vivos e um faleceu aos 16 dias. Fez laqueadura. Ela prefere a lavagem. A mãe ensinou, depois da relação, sempre fazer xixi. O preservativo causa desconforto, segundo ela, e não dá muito prazer. A laqueadura não foi escolhida, foi obrigada porque teve quatro cesáreas e engordava muito na gravidez. 0 médico falou que morreria, se tivesse outro. Não podia tomar comprimido, porque ficava inchada, nervosa, o cabelo caía, tinha muita irritação, dor de cabeça e o preservativo dava alergia, irritava e dava coceira, ficava inchada. Refere uma situação de violência: marido, embriagado, quis bater nela, recentemente. Deu tapas e empurrão. Caiu e machucou o braço. Ele chegou muito embriagado e chegou agredindo a ela e aos filhos. Foi ao hospital no domingo por causa de dor no braço. Falou que tinha caído e não falou da violência. Na segunda feira, não foi trabalhar, por dor física e emocional. $\mathrm{Na}$ segunda feira, conversaram muito e ele prometeu que não faria novamente. 
4. Denise, 43 anos. Nasceu em São Paulo (Capital). É branca. Tem o primeiro grau completo. Está desempregada. Foi técnica em um banco de sangue, por 6 meses. Atualmente, faz limpezas domésticas, uma vez por semana. Tem oito anos de casada. Teve um aborto espontâneo e tem dois filhos. Não está usando nenhum método. Alega que tem o útero virado e tem dificuldade de engravidar. Ela avalia positivamente a camisinha, apesar de não usar.

5. NP tem 28 anos, é branca, nasceu em Mairiporã e está em São Paulo há cinco anos. Estudou até a 7ạ serie do ensino fundamental. Parou de trabalhar para estudar. Foi detetive particular. A cor do parceiro é branca. Tem dois filhos. Para evitar gravidez, usam preservativo e coito interrompido e, segundo ela, os dois já se acostumaram.

6. Rosa tem 39 anos, é branca, tem 1 o grau completo. Trabalhou em escritório e como promotora de vendas. Nasceu em Paranavaí, no Paraná, e mora em São Paulo há 18 anos. Seu marido foi classificado como branco. Optou pela camisinha, como método, porque é mais higiênico e porque, usando camisinha não se corre o risco de engravidar e contrair doenças sexualmente transmissíveis; passa mal com o anticoncepcional. 
6 DESVELANDO RELAÇÕES ESPECÍFICAS ENTRE CONJUGALIDADE, GÊNERO E RAÇA, NO CONTEXTO DA SAÚDE REPRODUTIVA

De um ponto de vista antropológico, a individualização típica das metrópoles faz do modo de viver na cidade, característico de um certo estilo de vida, uma certa atitude blasé, que tudo nivela, que faz com que o significado e valores diferenciais das coisas sejam destituídos de substância. Estamos no universo a que se referiu SIMMEL (1987). Neste campo, o observador é parte obrigatória da observação. Imbuída de uma certa aproximação impressionista da realidade, empreendemos uma investigação, a partir dos discursos dos sujeitos investigados, buscando reter semelhanças e diferenças entre mulheres negras e brancas, no intuito de compreender 0 jogo das relações de gênero e raça e questão reprodutiva. Esta visão impressionista está associada à necessidade de um certo distanciamento dos dados para uma visão de totalidade.

A vida na cidade compreende uma dada modernidade e contém um certo individualismo como ideologia. Como caracterizou DUMONT (1985), o indivíduo tem, pelo menos, duas definições possíveis: uma, que se refere ao sujeito empírico e, outra, que diz respeito ao ser moral. VENTURI (2003) faz uma reflexão em torno da autonomia moral e o ideal de igualdade, fundado no iluminismo. Os graus de autonomia/heteronomia moral foram adotados como perspectiva teórica para, de posse de um modelo, aplicar à realidade e pensar como os sujeitos sociais e políticos se movimentam e conquistam mais liberdade individual. As feministas questionaram esse modelo, ao proporem pensar a diferença.

A emergência de novos sujeitos sociais e políticos, como as mulheres, fez questionar, segundo VENTURI (2003), em certa medida, o ideal de igualdade, fundado no iluminismo, estabelecendo o que PIERUCCI (2000) apontou como diferencialismo. As mulheres negras questionam a igualdade 
das mulheres e propõem mais uma diferença. As diferenças nas diferenças vão se sobrepondo, até não restar nada mais que o indivíduo único em sua existência.

DUMONT (1985:79) assinala que "Quando nada mais existe de ontologicamente real além do ser particular, quando a noção de "direito" se prende, não a uma ordem natural e social, mas ao ser humano particular, esse ser humano particular torna-se um indivíduo, no sentido moderno do termo". 0 autor prossegue sua reflexão para explicar como o individualismo e o racismo estão incrustados nas sociedades modernas.

É diante de uma realidade, que se caracteriza pela modernidade, que as mulheres entrevistadas, negras e brancas, vivem uma dada conjugalidade, confrontam idéias que vão se constituir como suas concepções, ou não.

De um ponto de vista psicológico, a individualidade e a conjugalidade são aspectos da vida de um casal que, por vezes, geram dificuldades para o convívio. Para FERES-CARNEIRO (1998), esta dificuldade deve-se ao fato de o casal encerrar dois sujeitos, dois projetos de vida, duas identidades individuais, uma história de vida conjugal, um projeto de vida de casal e uma identidade conjugal.

De um ponto de vista sócio-antropológico, a conjugalidade adquire contorno, a partir das reflexões sobre as relações de gênero e, neste âmbito, percebe-se na dinâmica conjugal uma perda considerável da individualidade das mulheres, a favor da família ou aliança conjugal.

De um ponto de vista analítico, a categoria "mulher", assim como a categoria "negro", são construções históricas e, ao serem desnaturalizadas, ou seja, retiradas do âmbito da natureza e colocadas no âmbito do social, evidenciam a (in)subordinação social. No âmbito das relações de gênero e raça, desvela-se maior ou menor poder e capacidade da mulher, em 
especial, mulheres negras, em desvencilhar-se das armadilhas e desafios colocados no cotidiano, podendo conformar-se, ou não, ao papel instituído culturalmente. É na intersecção dessas categorias que procuramos respostas para a nossa reflexão.

Como mulheres negras e brancas confrontam-se com a realidade e quais suas visões de mundo acerca de si mesmas, do trabalho fora de casa, do casamento, da liberdade e da maternidade, são questões que procuramos interpretar.

6.1 Visões de mundo acerca de ser "mulher", hoje em dia

Vivemos um tempo de ruptura com uma visão rousseauniana de "mulher" e de feminino. Na perspectiva de Rousseau, o feminino, corporificado em Sophie, parceira ideal de Émile, é complementar a ele e é feita não para si, mas para o homem (BADINTER 1985). A advertência de Rousseau, segundo BADINTER (1985), é que a mulher não deve reinar no mundo de "fora", o mundo exterior. Deve permanecer "dentro" dos limites da vida privada, sob pena de se tornar "anormal" e "infeliz". Essa visão secular de "mulher" e do feminino produziu uma moralidade, com a qual o mundo de hoje está rompendo.

A identidade feminina sofreu profundas transformações, ao longo dos tempos, e isto é percebido, em alguma medida, por mulheres brancas. As recentes conquistas femininas estão no dia-a-dia de mulheres, que se percebem muito mais atuantes, modificando a sua realidade e os diferentes cursos da vida, ativamente. É também presente a percepção de que o campo de ação das mulheres está para além do espaço doméstico. A vida é mais complexa, quando comparada com gerações anteriores. 
Acho que ser uma mulher hoje é uma atividade bem complexa, é árdua. Da mulher cuidar da casa, cuidar do filho, ser uma boa profissional, se sair bem naquilo que você faz, ter prazer naquilo que você faz, estabelecer uma relação afetiva que seja saudável, fazer a manutenção dessa relação afetiva. Ser mulher é uma missão, hoje em dia bem ampla, eu acho, e que às vezes, até cansa. Eu acho que isso é que é ser mulher, é cuidar de todos esses setores que envolvem a vida da gente, é zelar para que tenham saúde, que sejam saudáveis (Sonia, mulher branca, ensino superior, marido vasectomizado).

Mulheres negras também têm a compreensão de que o papel delas nesta sociedade é bastante importante. Não bastasse o trabalho que têm em casa, no cuidado dos filhos, da casa, dos velhos, dos doentes e de quem mais necessitar de ajuda, muitas trabalham fora, conquistam espaços onde 0 homem tem primazia. Por isso, ser mulher é sair em busca de seus ideais e dirigir sua própria vida, ao lado de alguém que pode, ou não, compreender suas atuais necessidades, como uma mulher de hoje, que conquistou espaços antes inimagináveis.

Ah eu acho que ser mulher, hoje, é você lutar pelos seus ideais.

Não só ficar para cuidar de casa e de filho, não. Eu acho que ser mulher, hoje em dia, se você tem um sonho, tem que ir atrás.Tem que estudar, tem que trabalhar. Buscar ter igualdade com os homens. Nós trabalhamos igual a eles e, às vezes, até melhor, e não somos reconhecidas. Ficar só dentro de casa cuidando de casa, de filho e de marido, isso, para mim, não é uma situação boa não e, também ficar fazendo o que eles querem. Porque tem homem que é muito machista. Tirando pelo meu. Acho que mulher não tem que ficar só dentro de casa, cuidando de filho, da casa e deles. Não, a gente tem que 
ter opinião própria. Tem que ir em busca dos ideais (Eliane, mulher negra, ensino fundamental, laqueadura associada à camisinha).

Existe a convicção entre mulheres, em diferentes grupos de escolaridade, de negras e brancas, de que o mundo mudou para as mesmas. Antigamente, referem algumas, as mulheres não poderiam nem sequer votar. Hoje, elas podem fazer o que quiserem. De onde vem esta certeza de que o mundo mudou? Algumas constatam diferenças, comparando suas vidas com as de sua mãe, ou avós, e isso se expressa, principalmente, no fato de elas poderem trabalhar fora, coisa que antigamente não Ihes seria permitida, já que eram "escravas do lar". Isto significava não poderem ter recursos próprios e mobilidade física, não terem o direito de ir e vir aos diferentes lugares. Hoje, afirmam algumas, as mulheres podem fazer o que quiserem. 0 direito ao trabalho remunerado é a principal garantia dessa liberdade. E afirmam, também, que a mulher vive, hoje, dividida entre dois mundos: o público e o privado. A escravidão da mulher no lar foi tematizada e sintetizada por Solimar, como podemos observar em sua fala:

Ser mulher, hoje, é estar olhando p'ra porta de fora de casa, sair de casa e ir para o mundo público; apesar de ainda terem várias prisões domésticas, a mulher de hoje, ela está p'ra fora, ela não, ela não consegue mais, ela não quer mais entender 0 seu universo a partir do seu universo doméstico, ela quer um outro universo, mas ainda ela está entre dois mundos. (Solimar, mulher branca, ensino superior, camisinha masculina).

Os universos, a que se refere Solimar, funcionam como pólos de atração que se dividem e, nesse movimento, conferem uma certa ambigüidade à ação. A identidade feminina, cindida e impossibilitada de realizar-se autonomamente, coloca-se no jogo das relações de gênero, 
subordinada em relação ao homem. Nessa dinâmica, percebe-se que mulheres ficam aprisionadas ao lar e às tarefas domésticas, como aponta a interlocutora:

A principal prisão doméstica é o trabalho doméstico. Essa ela é muito concreta, têm outras prisões domésticas que são as pressões psicológicas, os papéis sociais, a prisão sexual, as visões sociais de que as mulheres têm uma série de obrigações, agora elas já não são mais explícitas como regras, mas moralmente, registradas nas mulheres, que é o cuidado com os mais velhos, o cuidado com as crianças, as mulheres acabam fazendo isso. I sso é uma visão moral que ela não consegue quebrar, quer dizer, descobrir que o mundo inteiro é responsável pelos mais velhos, sendo nossos ou não, sendo nossos os velhos ou não. Essas são umas das prisões, mas eu acho que a mais concreta é a do trabalho doméstico, porque ele se traduz em horas de trabalho, em trabalho não pago, você dedica p'ra família de forma absoluta, como se fosse uma obrigação sua. Essa é a principal amarra, ainda, das mulheres; quando ela romper com 0 trabalho doméstico, acho que ela avança muito nessas questões, que eu coloco como questões morais da construção do ser mulher, que nós carregamos, dessas obrigações morais: má mãe, má filha. Ninguém é mau pai. Se não dá comida p'ra a criança, se bater, sim, mas se não der comida, ele não é um péssimo pai, mas uma mãe que não dá comida... ela é condenada socialmente (Solimar, mulher branca, ensino superior, camisinha masculina).

Um aspecto relevante no discurso das mulheres, do presente estudo, é a identificação da multiplicidade de papéis desempenhados pelas mulheres. É uma carga, em função da dificuldade de divisão eqüitativa com os parceiros, das atividades domésticas e responsabilidade com os filhos. 
Um outro aspecto muito importante, na descrição dessas mulheres, é a dupla jornada, por vezes, tripla. Mulheres negras declaram que vivem essa multiplicidade de papéis e se ressentem por isso. Faz parte do "ser mulher" pagar um certo preço pela liberdade, ou melhor dizendo, as mulheres assumiram inúmeras atividades fora de casa, em uma justa conquista da liberdade, sem terem se desvencilhado das obrigações do lar. Este aspecto muda, principalmente, no discurso de mulheres brancas de nível superior, que contam com empregadas no trabalho doméstico. Mas, no geral, o que elas referem, pode ser caracterizado no discurso de Hortênsia:

Várias coisas, uma delas é ter tripla jornada e apesar de a gente ter se libertado de alguns preconceitos e tudo, mas eu acho que tem alguns que ficaram ainda e eu acho que, não sei se é bom ou é ruim. É bom em que aspecto? É bom porque você tem mais liberdade de..., se o relacionamento não dá certo, você pode tentar outro. Antigamente, tinha o preconceito. Você pode sair a hora que você quiser, você pode viajar sozinha, você..., você tem independência, você tem liberdade. Isso, você não tinha antigamente. E tem esse fato negativo, que é a dupla, tripla jornada, às vezes. Acho que os parceiros não souberam muito lidar com esta questão. Você ser independente, você tem que fazer várias tarefas, parece que é tudo muito bonitinho, mas tudo muito pesado no final. Muito cansativo (Hortênsia, mulher negra, ensino superior, laqueadura).

Em vários discursos, fica evidente a falta de colaboração masculina e, mesmo, a dificuldade de dividir tarefas. Na maioria dos casos, a mulher multiplica-se ou divide-se para promover o bem-estar da família.

Um novo sentido e responsabilidade brota da nova situação vivida pelas mulheres. Ter atividades dentro e fora de casa faz com que as mulheres se 
definam como verdadeiras heroínas do cotidiano. Esse sentimento de luta e vontade está presente no discurso de mulheres, de uma forma bastante transparente.

[Ser mulher hoje em dia] Acho que é ser uma heroína e, ao mesmo tempo, eu acho que a mulher, ela poderia ter essa mesma classificação sem ter abarcado tantas tarefas, poderia ter dividido mais. Ela passou a participar do mercado de trabalho mais intensamente, mas não dividiu as tarefas, não sei se por que não quis ou porque não houve participação do parceiro para isso, que a sociedade brasileira, por ser muito machista não permitiu. Não consigo identificar tão claramente, mas ela poderia ser a heroína que é hoje, mas dividindo mais as tarefas. Ela continuou sendo a dona de casa, a mãe que cria os filhos, que educa, a trabalhadora, quer dizer, ela foi acumulando mais funções (Joana, mulher branca, ensino médio, camisinha masculina).

Embora, hoje, concepções sobre "mulher" passem a idéia de que a vida mudou, mulheres negras e brancas têm uma compreensão de que acumularam mais funções. A visão do sacrifício permanece na dupla, por vezes, tripla jornada de trabalho. Nesse sentido, a maior autonomia das mulheres depende do tipo de inserção social, possibilitada pelo trabalho fora de casa.

\subsubsection{0 trabalho da mulher fora de casa}

No mundo moderno, as mulheres, de modo geral, conquistaram novos espaços, devido à quebra de tabus e preconceitos, que limitavam a mulher ao espaço doméstico. Segundo LIPOVETSKY (2000), a mulher que 
caracteriza os tempos atuais é uma mulher que exerce o direito de escolha, em todos os campos, seja no espaço privado, seja no espaço público.

É no campo do trabalho que a literatura aponta para uma enorme diferença entre mulheres negras e brancas. Neste campo, a cor da pele seria um demarcador importante. E enquanto mulheres brancas estão seguindo rumo à emancipação, mulheres negras, ainda, têm muito a conquistar. De acordo com SOARES (2000), a mulher negra sofre, no mundo do trabalho, a dupla discriminação, por ser negra e mulher. 0 autor observou, em sua pesquisa, que há uma expectativa de melhora no quadro relativo ao mercado de trabalho para mulheres, mas isto não é válido para mulheres negras. Em sua análise, se houvesse 0 fim da discriminação, as mulheres negras ganhariam, na média, cerca de $60 \%$ a mais, as mulheres brancas ganhariam em torno de $40 \%$ a mais e os homens negros, entre 10 e $25 \%$ a mais, dependendo do lugar que ocupam na distribuição de renda. É um preço muito alto que se paga por ser mulher e ter a pele negra. 0 autor chegou a esse resultado, através de um calculo estatístico complexo, que mede as diferenças entre homens e mulheres, negros e brancos. A base de calculo foi extraída dos dados da PNAD (Pesquisa Nacional de Amostra Domiciliar).

Mesmo assim, o discurso de mulheres negras e brancas não difere quanto à importância do trabalho fora de casa. Ambas apresentam a idéia de que 0 trabalho fora de casa promove autonomia para as mulheres, em relação aos homens, e é o meio pelo qual as mulheres adquirem mobilidade e confiança. Essa independência tem um sentido amplo, pois a partir desta conquista, as mulheres podem definir seus destinos. OSIS (2001) observou, em sua pesquisa, que mulheres laqueadas e usuárias de métodos reversíveis valorizam diferentemente 0 trabalho fora de casa. Enquanto mulheres laqueadas consideram o trabalho fora de casa como uma ajuda ou complemento da renda da família, aquelas, que adotaram métodos reversíveis, o consideram uma parte importante, além de afirmarem a sua maior autonomia. Em nossa pesquisa, não foi possível observar este 
dado.Tanto usuárias de métodos definitivos, como de esterilização cirúrgica, assim como usuárias de métodos reversíveis, como a camisinha, valorizam o trabalho fora de casa e atribuem a ele a promoção de uma maior autonomia, empowerment, embora aquelas que optaram pela esterilização cirúrgica, em sua maioria, sejam negras e com menor poder aquisitivo, como é apresentado no capítulo subseqüente. 0 caso é que o trabalho é um valor em si. A escolaridade, no entanto, parece diferenciar as mulheres, em alguma medida. As de escolaridade fundamental e média, com menor capacidade de inserção no mercado de trabalho, teriam menor poder aquisitivo e menor possibilidade de se movimentarem na vida pública.

[E o que você acha do trabalho da mulher fora de casa?] Ah, eu acho maravilhoso. A mulher depe[...] mulher deve ser independente, não deve querer só depender do homem porque... se a gente depende deles, a gente se torna o que? Um capacho deles, eles acham que podem tudo, que pode mandar, que... e a mulher independente, ela pode erguer a cabeça, falar: "eu posso fazer isso. Eu posso..." tipo, é assim, às vezes, quando a mulher é dependente só do homem, tudo que ela vai comprar, aí fala: "bem, posso ir?", isso independente de como chama o marido ou não, ele sempre pergunta: "P'ra que? Por que?" E se você é independente, você não esta... não precisa dar satisfação. Não é que você não vai respeitá-lo, não é isso. Mas você não precisa estar ali, se humilhando, porque às vezes, só p'ra tirar você do sério, eles falam: "P'ra que você quer? Por que? O que você vai comprar? O que você vai fazer?" Entendeu? A independência da mulher é muito bom, muito bom, a melhor coisa que aconteceu... foi a nossa independência porque... esses homens, não dá certo (Sabrina, mulher negra, ensino fundamental, extraiu as trompas).

Separadas por diferentes escolaridades, mulheres negras e brancas, com ensino fundamental e médio, revelam que a necessidade de cuidar dos 
filhos contribui fortemente para 0 abandono do trabalho fora de casa e, conseqüentemente, a uma maior subordinação aos maridos. A falta de suporte social, como creches e escolas adequadas para deixarem os filhos no horário de trabalho, contribui para a maior dificuldade da inserção de mulheres no mercado de trabalho. Neste patamar, o trabalho, por vezes, é apresentado como uma obrigação, pois se trata de uma remuneração que possibilitaria uma vida melhor para os filhos e a família; entretanto, vive-se 0 dilema: "trabalhar fora e deixar os filhos com quem?" Mulheres negras e brancas não se questionam quanto à obrigatoriedade de seu trabalho doméstico. O cuidado com os filhos é necessidade humana vital e insubstituível. Arranjos são possíveis, mas, uma vez que existam os filhos, não é possível questionar-se a necessidade de cuidado.

Porque eu acho, assim, que foi uma conquista nossa, mas eu acho que a vida da gente hoje, como está, força para que a gente vá compor uma renda mesmo. Então, eu vejo assim: muitas mulheres que gostariam de ficar com os filhos, mas que não podem mais porque é uma grana que vai fazer falta em casa. Então acho que surgiu uma outra coisa, tem assim, a gente não tem o amparo, que eu acho assim que seria obrigação do governo que eles te amparassem nessa hora, quando você está saindo p'ra trabalhar, com quem estão os seus filhos, você tem que pagar uma pessoa e se você não tem a renda p'ra pagar uma pessoa p'ra olhar seus filhos, então eu acho que está tudo muito no papel, a questão da creche, e depois da creche, então deixa de existir, fica na escola quatro horas e vem p'ra casa e fica à mercê de uma televisão e da rua. Então, eu acho que a gente não tem esse amparo, porque nossos filhos eles continuam sendo filhos, a creche pega até os cinco anos e depois? Quem é que vai cuidar? E muita gente está ganhando mal, ela não consegue, se ela está saindo p'ra melhorar esse padrão, como que ela vai pagar alguém p'ra ficar com o filhos dela? Se ela vai ter que pagar, muitas 
vezes é exatamente o que ela recebe (Carla, mulher branca, ensino médio, marido vasectomizado).

Nos patamares de escolaridade média e fundamental, para mulheres negras e brancas, o trabalho fora de casa é citado como uma forma de independência em relação aos homens; diz respeito, portanto, ao âmbito das relações de gênero. Já as mulheres de nível superior qualificam o trabalho fora de casa como uma forma de desenvolvimento humano; citam que 0 mundo do trabalho promove 0 desenvolvimento intelectual, que 0 mundo doméstico não promove. Trata-se de uma escolha, como refere LIPOVESTSKY (2000). Mas, o conflito ainda é bastante claro, mulheres com filhos têm dificuldade de lidar com essa dupla responsabilidade, que implica ter um trabalho fora e cuidar dos filhos.

[Como você vê o trabalho da mulher fora de casa?] Como algo bastante conflitante, eu acho que ainda a mulher se cobra de ter tudo feito dentro de casa, de cuidar bem dos filhos, de organizar o lar, de fazer tudo bonitinho e querer sair para o trabalho, para o mercado e produzir e, também, ter sucesso, se sair bem no que ela venha a escolher. Eu acho que é uma coisa que é bastante conflituosa, mas é uma experiência muito necessária, eu acho produtiva, acho que contribui muito.

[Você acha que o trabalho colabora p'ra a liberdade das mulheres?] Sim, muito, eu acho que o trabalho enriquece todo ser humano, homem e mulher, eu acho que produzir é muito importante. Ė lógico que tem mulheres que se realizam ficando em casa, mas eu acho que sair, estar em contato com o mundo já é uma riqueza de experiência fantástica, eu acho que todo ser humano tem, ou, pelo menos, deveria experimentar isso (Sonia, mulher branca, ensino superior, marido vasectomizado). 
Diferentes inserções de mulheres no mercado de trabalho fazem com que a recompensa pelo sacrifício de deixar os filhos aos cuidados de outrem, seja maior ou menor. Pensando em relação à criação dos filhos, a maioria das mulheres negras e brancas pondera e repensa se o sacrifico vale a pena, porém, em relação aos maridos, a certeza de maior autonomia faz com que as mulheres ovacionem 0 trabalho. Mas, superadas as dificuldades de sobrevivência e arranjos no cuidado dos filhos, existem mulheres que consideram o trabalho como fonte de desenvolvimento pessoal e que ficarem em casa é ficarem limitadas pelas amarras do cotidiano.

Ah! Particularmente eu acho que a mulher tem que trabalhar, porque ficar só em casa, acho que é limitar ainda, a não ser que a pessoa tem condições de fazer coisas que gosta também, ficar estudando, lendo. Porque se for só para ficar em casa cuidando dos filhos é limitador. De conhecer mesmo mais o mundo, saber o que está acontecendo, saber, por exemplo, de questões políticas, de saúde. Se ficar só naquele mundinho doméstico, é empobrecedor. [Como é que é o mundinho doméstico?] Por exemplo, eu vejo as pessoas lá, por exemplo, onde eu moro, acordam cedo, levam os filhos para escola, voltam para casa, limpa casa, faz comida, lavam a roupa, ai vai buscar os filhos e ai traz os filhos, aí cuida dos filhos, espera o marido, ai cuida do marido. Então, é uma coisa muito fechada, tem que ter um, tem que ter... se relacionar mais com o mundo externo, estar mais atualizada (Regina, mulher negra, ensino superior, camisinha masculina).

A mulher vive conflitos que impõem escolhas, nem sempre fáceis, como, por exemplo, buscar garantir a sobrevivência dos filhos e deixá-los aos cuidados de outrem, ou ficar em casa e esperar que o marido traga 0 suficiente para o sustento da família. Ambas as escolhas requerem, da mulher, perdas significativas na sua concepção de vida, pois a maioria avalia que o trabalho contribui para sua autonomia, principalmente, econômica. 
[E o trabalho da mulher fora de casa, como você vê isso? Você acha que é uma forma de independência?] Total. Não há dúvida, por vários motivos, um dos motivos é a conseqüência econômica, ele dá maior liberdade econômica, e no Brasil, dado aos salários baixos, o rendimento ainda isso é muito complicado p'ra se falar em liberdade econômica, mas tem, dá liberdade econômica, ela tem seu dinheiro, que é usado, fundamentalmente p'ra sustentar a família, mas é dela, ela traz e isso é uma coisa importante. Outra coisa importante do trabalho da mulher é a experiência da vivência pública, antes ela não tinha essa vivência, o trabalho está no mundo público, não no mundo do privado, do doméstico, da família. É outro universo. Um universo masculino, difícil p'ra as mulheres conviver, mas é, eu acho que a mulher e o trabalho remunerado, público, digamos assim, porque 0 trabalho doméstico é trabalho também, mas ele não é público. Ele... ele trouxe à mulher essa magnitude dos universos que existem e que ela pode ocupar, quer dizer, o universo dela amplia de uma forma absurda, então eu acho que o trabalho p'ra a mulher traz essas duas coisas: a independência econômica, por uma lado, que altera e cada dia mais tem alterado as relações econômicas dentro de casa, não é, então ela questiona mais o poder, em tese, masculino, porque é masculino, uma vez que você passa a ter poder econômico, coisas começam a ser questionadas, no mínimo; e por outro que traz a ela a uma experiência que ela não tinha, que é a experiência pública. Eu acho que o trabalho hoje é o principal caminho da experiência pública feminina (Solimar, mulher branca, ensino superior, camisinha masculino).

As dificuldades de inserção da mulher no mundo do trabalho estão relacionadas à desigual relação de gênero e de raça. A futura emancipação para as mulheres brancas, como referiu SOARES (2000), passa pela 
transformação da realidade atual de opressão e submissão a uma situação de exploração, a que se refere Solimar:

[Você vê algum ponto negativo no trabalho da mulher fora de casa?] A super-exploração. As mulheres são super exploradas. Economicamente exploradas. Salários mais baixos, rendimentos mais baixos, pelo mesmo tipo de trabalho, o que é uma bandeira antiga, também. Outra coisa que eu acho, que ainda mulheres trabalham ainda, a maioria das mulheres, a mulher trabalha numa extensão do doméstico. Então, assim elas são domésticas, elas são babás, elas são costureiras, elas são cabeleireiras, elas são... que é o cuidado com 0 pessoal, que é o cuidado com o corpo, que é muito serviço... que eu diria, que é a expansão do capitalismo p'ra os serviços domésticos, tem muita mulher, entendeu. Então elas têm menos profissões de tecnologia avançada, de grandes executivas, elas não entram. Ainda eu acho que é pouco, é outro problema. Agora a universidade está cheia de mulheres, então isso tende a mudar, porque é conquistar uma coisa importante que é, dentro do espaço público, o conhecimento, deter o conhecimento. Claro que a universidade está mudada, está ficando muito técnica e pouco científica, mas sem dúvida isso é um avanço. Mas ainda no mundo do trabalho a exploração feminina é muita (Solimar, mulher branca, ensino superior, camisinha masculina).

Sem dúvida, sair para a vida pública, ingressar no mundo trabalho trouxe inúmeras conquistas às mulheres que, historicamente, tiveram sua identidade inscrita no mundo privado. Conforme assinala CHAUÍ (1985), a identidade feminina foi, desde o princípio, inscrita no mundo privado, seguindo as regras impostas a este mundo que, como aponta GIDDENS (1993), só recentemente está sendo democratizado, impulsionado pelas recentes conquistas femininas. 
No caso brasileiro, temos o autoritarismo que permeia as relações sociais. A vida pública, por esta via, segue as regras do mundo privado, que é marcado pela desigualdade (Da MATTA 1990). Neste campo, o autor se refere a um contexto, no qual as hierarquias, relativas ao poder, são negociadas. Levando em conta o que SARTI (1996) descreve em relação a famílias das classes populares, verificamos que o homem exerce uma autoridade moral, ou seja, é o portador da respeitabilidade no âmbito da família, sendo assim, mulheres sem parceiros estão destituídas de respeitabilidade. Como apontamos na introdução deste trabalho, são as mulheres negras que, em maior proporção, são chefes de família e possuem uma renda menor em relação às brancas (SEADE 1994)

O mercado de trabalho e a estrutura econômica e social no Brasil não oferecem condições favoráveis de trabalho para mulheres, ao contrário, há a super exploração, como refere Solimar (mulher branca, ensino superior), e há a ausência de equipamentos sociais que lhes dêem suporte, bem como creches e escolas adequadas às crianças, como referiu Carla (mulher branca, ensino médio). Políticas públicas são necessárias para que seja possível o trabalho da mulher fora de casa (BRUSCHINI 1994b). Tudo isso faz do mercado de trabalho um desafio para as mulheres. De um modo geral, mulheres têm consciência de que conquistaram uma maior liberdade e espaço em relação ao mercado de trabalho, mas olhando para suas vidas, nem sempre isso pode ser apontado com clareza. Há uma idéia geral de que a condição feminina está se alterando. Algumas escolheram não trabalhar, outras resolveram não terem filhos, outras vivem tentando conciliar as dificuldades de vida e uma dada condição de gênero e de raça. Trabalhar fora é produzir, estar ativa, participando da vida social. Quando se escolhe ficar em casa é para um melhor suporte para a família, no caso de mulheres de escolaridade média e fundamental, enquanto para as de escolaridade superior, que conseguem se manter trabalhando fora de casa com a ajuda de auxiliares e o marido, o trabalho é uma escolha. 
O trabalho da mulher fora de casa está cada vez menos relacionado ao seu ciclo de vida, que inclui casamento e maternidade. Segundo RIOS NETO e WAJ NMAN (1994), as taxas de participação da mulher no mercado de trabalho têm aumentado, mesmo após a maternidade e o casamento. Mesmo assim, a dupla jornada tem caracterizado, historicamente, a condição feminina (OLIVEIRA 1989).

Mulheres de classe média, diferentemente de mulheres das classes populares, adentraram o mercado de trabalho mais precisamente na década de 20, quando o magistério passou a ser considerado uma profissão respeitável para uma mulher, pois permitia a conciliação do trabalho com as tarefas domésticas, além de "aliviar as grandes famílias do peso das tias solteiras"( LEITE 1993b: 195). Nesse patamar, as mulheres ainda não tinham acesso a carreiras universitárias.

Trigo (1994), referindo-se ao Brasil, relata que as mulheres adentraram as profissões universitárias, de modo significativo, na década de 60, quando foram possíveis mudanças nas tradicionais relações de gênero. Ou seja, mudanças das relações de gênero dicotomizadas. Começava a se configurar uma situação em que o trabalho passa a ser visto com um direito e uma escolha. Para BRUSCHINI (1994a), na década de 80, apesar da crise, houve um crescimento da participação feminina no mercado de trabalho e um aumento significativo de mulheres mais velhas, instruídas, e mães no mercado de trabalho, demonstrando que as mulheres realmente estavam sendo incorporadas ao mundo do trabalho. As causas apontadas para essa modificação são diagnosticadas, através da queda da fecundidade, aumento da escolaridade, aspiração por um consumo diversificado, entre outras.

Ainda que permaneça uma certa discriminação de gênero, o consistente aumento da participação da mulher no mercado de trabalho, apesar da crise econômica, tem revelado, nas últimas décadas, uma participação mais efetiva de mulheres mais velhas e instruídas. Estas têm a 
possibilidade de se inserirem em posições mais qualificadas, de modo que sua remuneração compensa os gastos que têm para administrar a casa e os filhos (BRUSCHINI 1994b; 2000).

Constatam-se, nesse campo, as recentes conquistas femininas a que se referem GIDDENS (1993) e BRUSCHINI (1994b;2000), principalmente para aquelas mulheres de escolaridade superior, caracterizando a modernidade pela integração da mulher na vida pública e a crescente democratização da vida privada, como reflexo dos avanços na vida pública. Entretanto, quando nos reportamos à realidade brasileira, defrontamo-nos com o autoritarismo a que se referia DaMATTA (1990). Nesse contexto, a problemática racial se inscreve para desnudar, ainda mais, uma realidade marcada pela desigualdade.

Bairros, citada por BAIRROS, CASTRO e SÁ BARRETO ( 1990), já havia verificado uma associação entre ocupações mais desvalorizadas e maior participação do negro. Segundo BENTO (2000), a mulher negra vive em situação de maior precariedade no mercado de trabalho brasileiro, porque é excluída de postos de trabalho que exigem maior escolaridade e "boa aparência". O fato de ser negra seria impeditivo, em algumas situações de trabalho, em que o padrão de "boa aparência" é eurocêntrico. Este requisito da "boa aparência" também leva a um mecanismo de autoexclusão, conforme a autora. 0 racismo e o sexismo atuam de forma combinada, reforçando a subordinação, segundo BAIRROS (1991). Sobre este assunto, é interessante recorrer a LELIA GONZÁLEZ (1982) para a reflexão sobre a condição da mulher negra. Ela aponta para a tripla discriminação: de raça, de classe e de sexo. Discriminação esta que, muitas vezes, foi internalizada de tal modo que o sujeito não se apercebe que, no próprio discurso, estão presentes "mecanismos da ideologia do branqueamento e do mito da democracia racial"(GONZÁLEZ 1982:100). 
As diferentes inserções no mercado de trabalho revelaram-se no discurso, como um tipo de liberdade exercida pelas mulheres brancas, diferentemente da mulher negra, que têm mais caracteristicamente uma história de trabalho fora de casa para manter a família junto ao companheiro, ou sozinha, e só equiparada à mulher branca pobre (LEITE 1993 a), a mulher branca de classe média se inseriu nas décadas de 20 e 30 no mercado de trabalho (LEITE 1993b) e teve sua inserção em profissões de nível universitário nas últimas décadas (TRIGO 1994), disputando as vagas em outro patamar. Foi diferente a situação de mulheres brancas, da classe operária, que ocupavam, tradicionalmente, postos de trabalho e que exigiam menor qualificação e escolaridade (MOURA 1988), gradativamente recolocadas de volta ao lar em um projeto higienista da sociedade brasileira, como relatado por RAGO (1987). A respeito da mulher negra e condições de vida e trabalho, BERNARDO (1998), estudando a memória de velhos, revela como eram difíceis e o quanto mulheres sofriam com a desqualificação profissional, em São Paulo. Os dados do Boletim 4 do $\operatorname{SEADE}(\mathrm{s} / \mathrm{d})$ corroboram, ainda, a afirmação de que as mulheres negras vivem condições mais desfavoráveis no mercado de trabalho, recebendo menos que os homens negros, mulheres não negras e homens brancos enfrentam, também, maiores períodos de desemprego e estão em ocupações mais vulneráveis. Essas observações já tinham sido feitas por LIMA (1995), para quem, mulheres negras, mesmo que consigam romper os limites e avançar na sua escolaridade, ocupam posições menos reconhecidas. Os ganhos auferidos por mulheres negras são menores do que os de mulheres brancas e isto se reflete nos dados de nossa pesquisa, conforme é possível visualizar nas figuras abaixo, em que, na maioria dos casos recolhidos, as mulheres negras têm uma renda menor que as brancas. 

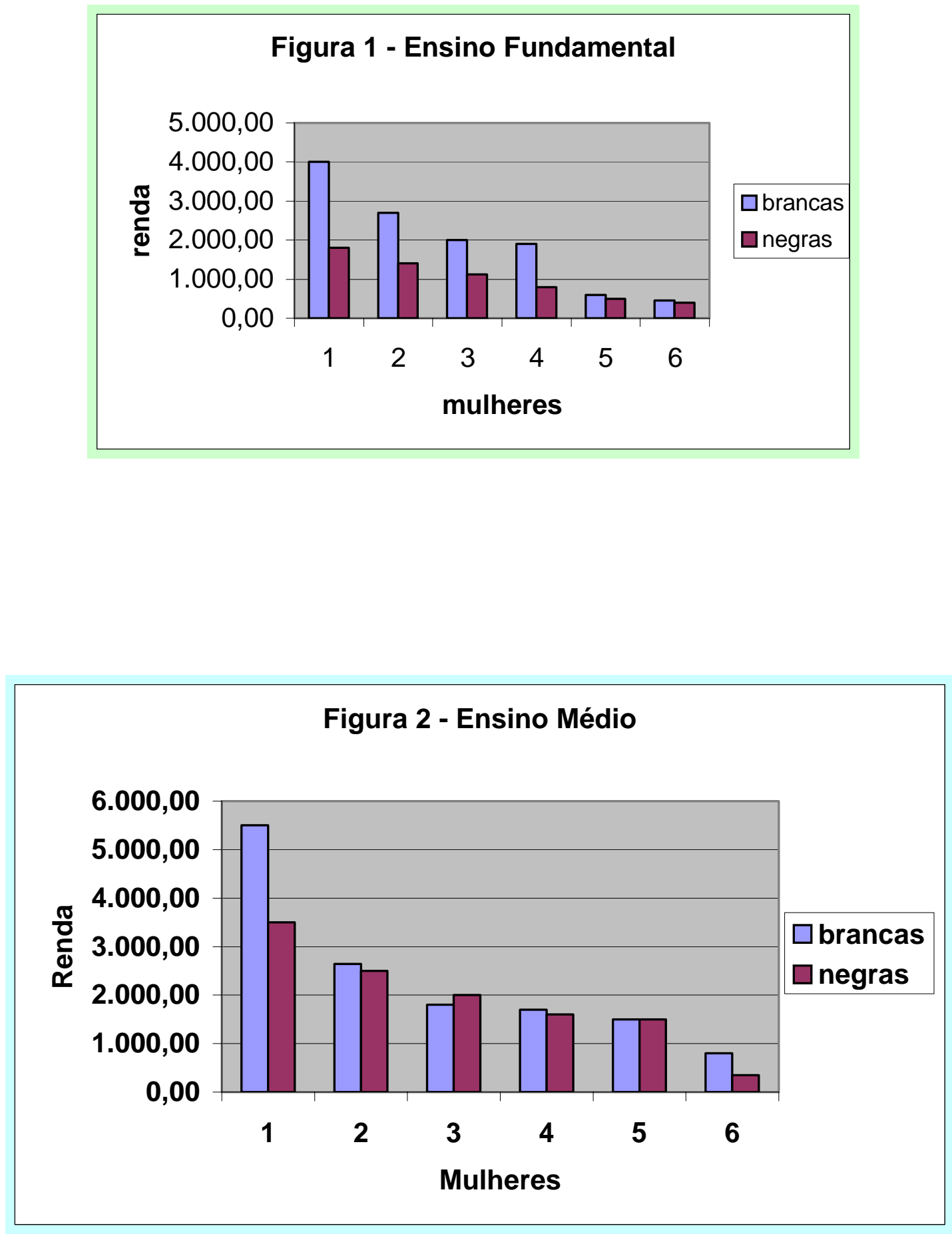


\section{Figura 3 - Ensino Superior}

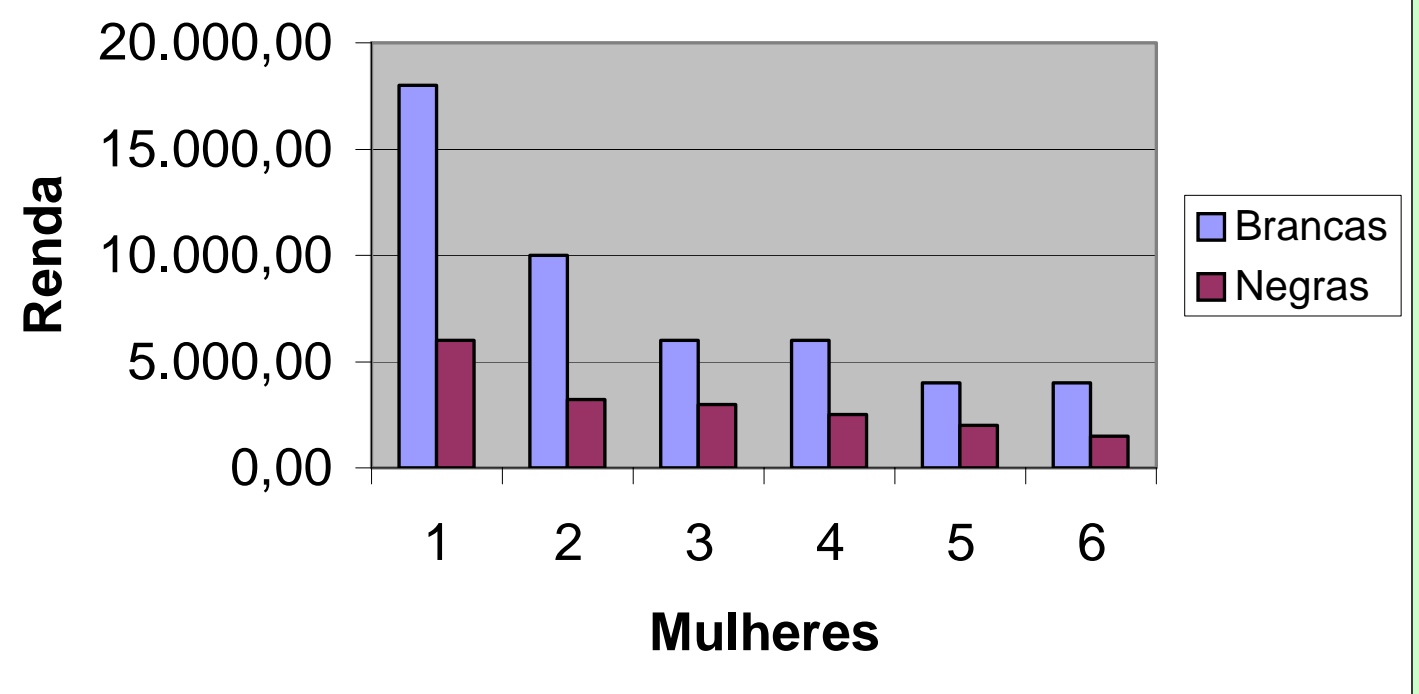

Tendo observado que as mulheres negras, independentemente da escolaridade, apresentam um padrão de renda e inserção, no mercado de trabalho, diferente das mulheres brancas, procuramos verificar como se dá o exercício da autonomia. Neste âmbito é que a liberdade se coloca como a possibilidade de autodeterminação, autonomia a que mulheres negras e brancas, de escolaridades fundamental, média e superior podem vivenciar no seu cotidiano.

\subsubsection{Liberdade}

Na análise de GIDDENS (1991), a vida moderna eliminou a fronteira entre o "nós" e os "outros" e os riscos que poderiam estar no mundo dos "outros" fazem parte do nosso mundo, porém distribuídos desigualmente, rehierarquizados. 
A autonomia moral dos indivíduos frente a essa modernidade depende muito das condições sociais, culturais e institucionais para o seu desenvolvimento e a cidadania pressupõe 0 usufruto da liberdade e a responsabilidade (VENTURI JR 2003).

Segundo GIDDENS (1993), a intimidade está sendo cada vez mais democratizada, num movimento de fora para dentro do campo da vida privada. Esse processo de democratização, alavancado pela revolução feminista no cotidiano, possibilitou a constituição de sujeitos políticos para exercício da cidadania. Para RODRIGUES (2001:238), "O exercício de cidadania compreende duas ações interdependentes, a primeira refere-se à participação lúcida dos indivíduos em todos os aspectos da organização e da condução da vida privada e coletiva; e, a segunda, diz respeito à capacidade que estes indivíduos adquirem para operar escolhas".

A emancipação feminina, em direção ao direito à escolha, já deu largos passos em direção à autonomia. 0 casamento, por muito tempo, foi a única forma de as mulheres obterem uma identidade social, e o contrato matrimonial, datado na origem do patriarcalismo, tem como base a dominação e sujeição da mulher ao homem. Equiparada ao escravo, em face desse contrato matrimonial e sexual, a mulher, historicamente, não exercia o mesmo direito que o homem, direito esse alocado no "individuo" e referido à masculinidade. Ligado ao patriarcado, o contrato matrimonial e sexual não permitia a igualdade à feminilidade e a liberdade de fazer acordos e contratos se referia às pessoas com direito político, o que era negado à mulher e referido aos homens (PATEMAN 1993). A liberdade dos "indivíduos", referida no 'contrato social' em Hobbes, Locke e Rousseau, segundo PATEMAN (1993), não alcançava as mulheres porque elas estavam no lugar do "não-sujeito". Mulheres negras têm se firmado como sujeito social e político, como vimos no ítem 2 , de forma que a história tem se transformado. A questão da diferença, nesse debate, coloca-se com a intenção de problematizar e transformar valores e normas sociais impostas 
por uma dada moralidade. A mulher negra, colocada duplamente no lugar de "não sujeito", estabelece uma diferença na diferença. Sob a égide do diferencialismo, em oposição ao igualitarismo, instaura-se um dilema ou, mais propriamente, uma "cilada", como aponta PIERUCCI (2000). Penso sobre esta questão que, ao ampliar o horizonte e as identidades, possibilita um alcance maior de justiça e de autonomia. Trata-se de "pluralizar" os negócios humanos, como assinala Arendt (apud TELLES 1999). Como refere DARCY DE OLIVEIRA (1991), a mulher passou da luta pela igualdade para a luta pelo direito à diferença, sem prejuízo para igualdade de direitos.

Pensar a liberdade, nesse sentido, é fundamental para a avaliação dos processos de decisão e escolhas reprodutivas, historicamente, um campo em que se refletem a dominação e sujeição das mulheres negras e brancas. No que se refere à cidadania, tal questão é crucial, em um sentido amplo. Daí nosso interesse em reter, a partir do discurso de mulheres negras e brancas, a concepção de liberdade que está presente nas falas das entrevistadas.

Podemos pensar que mulheres negras e brancas, de escolaridades diferenciadas, vivem em maior ou menor heteronomia ou autonomia moral, partindo do pressuposto que os sujeitos sociais e políticos - mulheres negras e brancas - estão em patamares distintos da trajetória em direção à autonomia moral, se avaliarmos a partir do modelo proposto por VENTURI (2003). SOUZAS e ALVARENGA (2001) observaram que, entre mulheres de baixa renda, o discurso de liberdade está referido ao direito de ir e vir, limitado pela atuação dos maridos, que obstaculizam a sua ação. Numa ação que requer a capacidade de decisão e escolha e a participação dos parceiros, como no planejamento familiar, por exemplo, mulheres vêem-se impedidas por uma relação de gênero rígida e com pouco diálogo. É nesse sentido que procuraremos compreender, por meio do discurso de mulheres, as concepções sobre liberdade. 
o grau de liberdade, que usufrui a mulher, determina sua autonomia. Neste aspecto, a discussão conecta-se com uma reflexão de ALICE MILLER (2003), quando disserta sobre direitos sexuais. Para esta autora, os direitos sexuais estão ligados à autonomia e dignidade humana, e não a uma identidade sexual. Aponta, como um aspecto radical das demandas pelos direitos sexuais, o enfrentamento de esteriótipos sexuais que se dá com a participação das pessoas mais atingidas e mais marginalizadas. É interessante, neste ponto, pensar que, no Brasil, as mulheres negras são preteridas do mercado matrimonial, como aponta BERQUÓ (1986) e supervalorizadas, como exóticas, para o tráfico sexual, como denunciam pensadoras do movimento negro. 0 esteriótipo a que as mulheres negras estão submetidas impede-as de usufruirem a liberdade, inclusive, sexual, e um exercício da sua autonomia e dignidade, ferindo, portanto, os direitos sexuais das mulheres negras.

As mulheres brancas apontam para uma ilusória liberdade, o "feitiço contra o feiticeiro", como se a busca pela igualdade, ou pela afirmação da diferença, tivesse colocado as mulheres numa "cilada" (PIERUCCI 2000). Ao terem sua diferença afirmada para contestar um tratamento desigual, tiveram a sua condição diferenciada, justificada na própria diferença, colocada por elas mesmas.

As visões de mulheres brancas e negras diferem com relação à idéia de liberdade, apontando para uma vivência distinta. Enquanto o primeiro grupo aponta para uma falsa liberdade das mulheres, que continuam subordinadas, de diferentes formas, na relação conjugal, o segundo grupo, as mulheres negras, entende a liberdade, sobretudo referida ao poder se expressar no diálogo com o parceiro, ou melhor dizendo, para a possibilidade de vivência democrática da conjugalidade. Essas diferentes formas de conceber a liberdade sinalizam para diferentes compreensões da sua condição de gênero e raça. Enquanto mulheres brancas problematizam essa condição e a possibilidade de exercício efetivo da liberdade, mulheres negras 
apontam para a conjugalidade, na realidade atual, e para o avanço da possibilidade de diálogo.

Entendemos que essa compreensão diferenciada de liberdade se dá em função das diferentes condições de gênero, raça e condição social das mulheres. Estes três elementos articulados dão às mulheres uma possibilidade de vivência sexual e afetiva diferenciada. Enquanto mulheres brancas buscam superar uma certa dicotomia na relação, mulheres negras buscam construir uma relação conjugal que, ao longo do tempo, foi dificultada, em parte, pela condição histórica de escravidão. Como aponta BERNARDO (1998), a família negra, formada inicialmente por mãe e filho, com o advento da Lei do Ventre Livre, excluía o homem negro, pela sua própria condição. A mulheres negras, portanto, ocupavam um lugar central na formação dessa família. BEOZZO (1993) destaca a fragilidade das famílias escravas e como a igreja cumpriu um papel importante na intervenção junto aos senhores de escravos para a manutenção desse tipo de família. As escravas, quando engravidavam, muitas vezes, praticavam o aborto para que o filho não sofresse a mesma sina. A legislação da época apoiava fracamente esse tipo de organização social e, muitas vezes, como foi o caso da lei dos sexagenários, surgia para proteger os senhores de qualquer tipo de obrigação com a escravaria.

As mulheres negras, como relatam de SOUZA, BALDWIN, ROSA (2000), eram utilizadas como objetos sexuais dos brancos portugueses. Depois, com a chegada de mulheres brancas portuguesas, as negras eram mantidas como concubinas, enquanto mulheres brancas, colocadas em um papel de completa submissão, eram responsáveis por gerarem a prole legítima e herdeira. Sendo assim, a história da mulher negra e escravidão aponta para a ilegitimidade da conjugalidade, em casos em que a mulher era negra, e para a rigidez dos papéis sexuais. 
A idéia de parceria, no relacionamento conjugal, é uma idéia nova, e faz parte das conquistas femininas (GIDDENS 1993). A vivência da conjugalidade, no sentido moderno do termo, como uma experiência de compartilhamento é, então, uma novidade na vida das mulheres negras. Agrega-se a isso a constatação de BERQUÓ (1987) que, ao analisar a nupcialidade da população negra, identificou uma maior solidão das mulheres negras. Este dado agrega mais valor à conjugalidade. Percebe-se, então, nessa questão, uma diferença étnico-racial.

As mulheres brancas

Com relação à liberdade, mulheres brancas, de escolaridade fundamental, consideram que as mulheres conquistaram uma falsa liberdade, hoje em dia, com isso apontam para uma visão essencialista da "mulher". Elas podem trabalhar, prover a casa e a família, mas elas não obtiveram a liberdade almejada. A liberdade está limitada à necessidade de cuidado dos filhos e aos cuidados domésticos da casa. A "mulher" será sempre mulher, no sentido vitimizante do termo.

Uma falsa liberdade. A não ser que ela seja totalmente independente, mas se ela é casada, que nem no meu caso. Está ali do lado do marido, é uma liberdade entre aspas. Não é totalmente liberdade não. Se fica presa a muitas coisas, a filho, casa, marido e essas coisas ( Mary, mulher branca, ensino fundamental, não está usando nenhum método).

A mulher branca, de ensino médio, pensa nas próprias armadilhas que o jogo das relações de gênero impôs. Entende que a liberdade é uma quimera, que não foi alcançada pelas mulheres e que têm suas potencialidades "ceifadas". Deste ponto de vista, a sociedade colocaria obstáculos para a mulher. 
Ela trabalha, cuida de casa, cuida de marido, cuida de filho, é amante, muitas vezes ainda estuda, qual a hora de liberdade dela? De se expressar de que faz tudo isso, chega na hora de ela querer ter uma liberdade mesmo, de bater o martelo, muitas vezes ela é ceifada (Amália, mulher branca, ensino médio, marido vasectomizado).

Mulheres brancas, de nível médio, se perguntam sobre esta liberdade. "Será que mudou mesmo?" Indagam algumas. "Será que não estamos confundindo ainda mais as coisas?". Este sentimento de liberdade e confusão aparece em discursos, quando perguntamos sobre a liberdade da mulher, hoje em dia. De onde vem esse sentimento? Pelo discurso de mulheres brancas, é possível perceber que elas se colocam como estando ao meio de um caminho. A conclusão de algumas é que a mulher não tem liberdade, para além das obrigações do lar.

A mulher, hoje, ela tem liberdade p'ra tudo, ela tem direitos, ela tem o direito e o dever de prover, de dar à luz, de ser mulher, de ser amante, de ser esposa, mas a liberdade de, algumas vezes, ela fazer algumas coisas que ela gostaria de fazer ela não o faz, porque a sociedade não admite [Que tipo de coisas?] Ah, falar besteira numa roda de homens, estar num lugar onde só tem homens, as outras pessoas vão falar "Nossa, uma mulher casada, com filho num lugar que só tem homens", se tem muitos amigos gays, é porque ela tem tendência a também ser gay (Amália, mulher branca, ensino médio, marido vasectomizado).

A forma como se dá a conjugalidade não permitiria às mulheres desenvolverem a sua individualidade e, por conseguinte, a sua liberdade. Deste ponto de vista, coloca-se o foco na dinâmica das relações de gênero e, mais especificamente, nas relações conjugais. 
Em relação mais ao parceiro, às relações... Eu acho que na verdade não existe[a liberdade], por exemplo, no que se refere ao parceiro, que ela, que ela não ... de uma maneira global, que eu convivo num meio, onde as mulheres que conheço elas não se encaixam no todo neste perfil, mas a maioria, pelo que eu percebo, as mulheres, elas tem muito receio de discutir a relação, de rever a postura de cada um dentro desta relação e fazer essa divisão. E não é só um receio, porque o parceiro não dá esse espaço, eu entendo que o espaço é conquistado. Porque não dar o espaço e ficar calada, é consentir com essa ausência de espaço. Então, eu acho que a mulher, em nome de muitas coisas, perde essa liberdade que ela poderia ter, esse dividir. Em nome do que? De manter uma relação, por exemplo, talvez o risco que ela imagina ter que, talvez não tenha, ou talvez tenha e talvez ela queira manter uma relação que talvez nem exista de fato, por que 0 que é relacionar, é dividir, eu imagino, eu penso dessa maneira, mas ela tem já uma carga que vem da criação, ou seja, que vem da mãe dela,da avó dela e que ela ainda não reformulou, ainda está na forma só, falta o conteúdo ( J oana, mulher branca, ensino médio, camisinha masculino).

As mulheres brancas vêem, de modo geral, que sua liberdade pode ser ampliada. A visão das mulheres brancas, de escolaridade de nível superior, é que o trabalho é uma forma de exercício da independência feminina e de liberdade; esta visão é corroborada pelos parceiros e vai ao encontro do que LIPOVETSKI (2000) assevera para a "terceira mulher": o direito de escolha. A liberdade, em seu sentido amplo, ainda está por ser conquistada, mas já é vislumbrada por algumas delas como, por exemplo, no caso da independência econômica; no direito de ir e vir, na liberdade de expressão dos desejos e outras conquistas. 
[Você acha que a mulher hoje ela tem maior liberdade, do que há alguns anos atrás? Isso mudou, não mudou?] Por exemplo, eu acho que ainda... as mulheres avançaram muito em independência econômica, e eu vou estar falando no meu caso específico, porque eu falar de todas as mulheres, de gênero, eu acabo não vendo e resgatando a minha própria experiência que é, de liberdade, eu não tenho a menor dúvida. Eu sou de uma geração que conquistou liberdades importantes, eu tenho independência econômica, e isso é fundamental para discutir liberdade, não é? Porque isso me garante fazer algumas coisas que antes não eram garantidas. Eu acho que as mulheres de hoje, as opiniões, elas têm opiniões, falam dessas opiniões, têm a liberdade de poder falar, a liberdade de poder sair, a liberdade de poder sentir, várias liberdades nós já conquistamos, acho ainda que tem muito a avançar, muito a avançar, que é a liberdade de decidir, sobre o poder. Ter poder social, ter poder político, ter poder econômico igual. Eu acho que nós não conquistamos plenamente, mas a trajetória feminina é uma trajetória de conquistas de liberdade (Solimar, mulher branca, ensino superior, camisinha masculina).

As mulheres brancas, de nível médio e fundamental, apontam para uma situação de maior heteronomia, que as mulheres brancas de nível superior, que podem superar, através de uma inserção mais efetiva na sociedade e, mais especificamente, no mercado de trabalho, conquistando uma maior autonomia e liberdade.

As mulheres negras

As mulheres negras, de escolaridade de nível fundamental, percebem dificuldades no exercício da sua liberdade, mas desafiam tais 
obstáculos, impondo sua presença e hábitos, antes questionados como femininos. A dinâmica da relação conjugal é, forçosamente, flexibilizada para permitir a liberdade feminina que querem exercer. Percebe-se, no discurso, que o quê se quer conquistar é o espaço público, figurado no discurso de Pámela, como espaço também de lazer, além do trabalho. Diferente da mulher branca, ela apresenta um discurso menos preso às convenções do papel feminino e masculino.

Às vezes, em que situação, assim, quando eu saio do serviço e fico assim, fico no barzinho com as colegas. Não é barzinho, assim...que tem do lado do serviço, que a gente bebe uma, duas, três cervejas. Assim, no último plantão, antes de vir embora. Ai eu não ligo, não dou ouvido (risos). Porque se ele pode fazer com os amigos, por que eu não posso fazer com as minhas amigas? Claro. Aí, eu faço do mesmo jeito (Pámela, mulher negra, ensino fundamental, laqueada).

A ausência de liberdade, mais especificamente do direito de ir e vir, é constatada por Eliane. A possibilidade de exercício da liberdade é limitada pelo companheiro. O lugar do lazer é o lugar convencionalmente ligado à paquera, também de acesso a outros homens (SOUZAS e ALVARENGA 2001). É interessante observar que Eliane afirma que a mulher tem o direito de trabalhar fora, mas não de lazer, sem a companhia do marido, o que é reivindicado por Pámela, interlocutora anterior.

Ele não aceita toda essa liberdade não. Ele acha que a mulher tem direito de trabalhar fora, de ter igualdade com o homem, mas, por exemplo, a liberdade da mulher querer ser livre, querer sair de casa, por exemplo, para passear, sem ele estar junto, sair com amiga, fazer todas essas coisas, ele não concorda não (Eliane, mulher negra, ensino fundamental, laqueadura associada à camisinha). 
Diferente da mulher branca, de nível médio, que reivindica uma liberdade equiparada à do homem, a mulher negra, de igual escolaridade, reivindica um tipo de liberdade atualizada, não equiparada à do homem, mas maior do que era permitido antigamente, quando a mulher era mais subserviente ao homem na relação conjugal.

[E o que você acha da maior liberdade que as mulheres têm hoje?] Muito bom, ótimo, porque antigamente a gente não tinha, não é?, este tipo de liberdade. Eu tiro pela minha mãe, muitas coisas ela queria fazer e não fazia... Hoje, não... hoje nós temos, não é?, várias coisas, tipo: se a gente quer trabalhar fora... Já é um grande passo pra mulher. [Quando você fala assim "ah, no tempo da minha mãe era diferente". Em que sentido, mais ou menos, você acha que era diferente?] Tá. Por exemplo, trabalhar fora. Hoje nós podemos. Se a gente falar assim "quero trabalhar fora"..é lógico que existe ainda muitos homens que não deixam, mas na época da minha mãe, não podia mesmo. Você tinha que obedecer ao homem, tinha que ser... não respeito, era obediência mesmo. Hoje não, hoje você tem respeito pelo teu marido, você não tem medo do teu marido. Pelo menos é o meu caso

(Marina, mulher negra, ensino médio, não está usando nenhum método).

Por um outro lado, mulheres de ensino superior mencionam ter a liberdade de ir e vir, que algumas mulheres negras, de nível fundamental e médio, reivindicam para seu cotidiano. Hortênsia menciona, também, que essa liberdade tem um preço "arcar com as conseqüências", que está associada à possibilidade de decidir sobre a sua própria vida e destino. As mulheres identificadas como de "classe média", para Hortência, são as que ficam presas a conceitos e convenções e que, portanto, não exerceriam a liberdade. 
[O que acha da liberdade da mulher hoje em dia?] Eu acho muito positivo, muito positivo.[Em que aspecto é positivo?] Ah porque antes você ficava muito presa a conceitos, a família e hoje não. Você pode batalhar pelo seu próprio espaço. Você pode... tem o direito de ir e vir a hora que quiser sem pedir satisfação. Se bem que algumas ainda ficam presas. [Algumas, que mulheres ficam presas?] Ah eu vejo as da classe média principalmente. [As da classe média?] As da classe média principalmente.Tem que pedir autorização para marido ir nos lugares. Não tem nada a ver. Acho que todo mundo é livre para fazer o que quiser. Acho que nesse ponto que é a liberdade. Você pode fazer o que você quiser, aí você arque com as conseqüências (Hortênsia, mulher negra, ensino superior, laqueada).

As mulheres negras, de ensino superior, percebem 0 alcance das conquistas femininas no cotidiano, vivem essa liberdade e a concebem como uma possibilidade de poder se expressar sem constrangimento do parceiro, com liberdade de pensamento. A questão da liberdade exclui a experimentação do sexo, para além do relacionamento conjugal. É a idéia da monogamia absoluta, como elemento constitutivo da conjugalidade das mulheres, como é apontada pela interlocutora Luísa. A liberdade, para Luísa, é abdicar dessa possibilidade sexual, é "não ter uma relação conjugal e uma relação extra conjugal", é ter relação monogâmica, compartilhada, a conjugalidade, como uma construção efetiva na vida das mulheres negras.

Tem que ver o que é liberdade. Liberdade p'ra mim, dentro de um relacionamento, é você poder ter o seu pensamento, as suas idéias, você ser respeitado, é uma coisa, e outra coisa eu não sei se as pessoas colocam isso, o conceito de liberdade, é você poder partilhar as coisas com seu parceiro. Ele poder partilhar com você. Você poder sentar dialogar, conversar de tudo. Entendeu. Até de uma simples coisa. "Ah eu vou fazer isso hoje, eu vou fazer aquilo", aceitação. 
Acho que isso é uma questão de liberdade. Eu não chamo de liberdade, aquilo de você ter uma relação com liberdade. É não ter uma relação conjugal e uma relação extra-conjugal. Compreendeu? Porque isso aí, eu não sei se isso é liberdade. Isso é opção. Você optar por viver assim. Ah agora em relação eu produzir, ter a minha vida, trabalhar, ganhar o meu dinheiro. Isso é muito tranqüilo no meu relacionamento. I sso eu chamo de liberdade. Não esse outro lado que eu te falei (Luisa, mulher negra, ensino superior, camisinha masculina).

A liberdade de compartilhar, dividir, ainda, é uma quimera para muitas mulheres. Tal liberdade coloca-se desta forma, tendo em vista relatos de caso, como o apresentado por PINTO (2002). Ao analisar a questão do aborto, aponta para a solidão em que vivem, principalmente as mulheres negras, no processo de decisão pelo abortamento. Percebe que os informantes brancos incorporaram os mitos com relação à sexualidade negra e vêem as mulheres negras como objeto sexual, ao passo que informantes negros incorporaram o ideal de brancura, com todo o poder que ela representa, preferindo filhos miscigenados, embora os brancos não as vissem como mãe para seus filhos.

Com isso, observa-se que a decisão, mais especificamente a reprodutiva, está enredada em formas de poder nas relações sociais. Nesse contexto, a liberdade, segundo CHAUÍ (1985:36), "não é, pois, a escolha voluntária em face de várias opções, mas a capacidade de autodeterminação para pensar, querer, sentir e agir. É autonomia". Liberdade é, ainda, a capacidade que temos para transformar uma dada realidade, por exemplo, de exclusão, e construir uma relação igualitária.

Para BOBBIO (1997), a liberdade positiva diz respeito ao exercício de uma vontade autodeterminada e não heterodeterminada, é uma liberdade que diz respeito ao cidadão, porque este consentiu as leis que regulam a sua 
ação. É uma liberdade de sujeitos autônomos, autodeterminados. Isto posto, a relação de gênero igualitária, a que se refere GIDDENS (1993), pressupõe o exercício da liberdade.

Sem serem antagônicas, as concepções de liberdade de mulheres negras e brancas possibilitam identificar a visão de algo a ser superado pelas mulheres. As visões de liberdade permitem perceber que os dois segmentos, 0 de mulheres brancas e 0 de mulheres negras, direcionam suas reflexões para a constatação de que houve uma mudança no mundo das mulheres. Mas, enquanto mulheres brancas pensam na defasagem das mulheres, no exercício eqüitativo da liberdade em relação aos homens, mulheres negras pensam na possibilidade de vivência democrática da conjugalidade. Estas diferentes concepções são especialmente relevantes para se pensarem as escolhas reprodutivas de mulheres negras e brancas e desvelar uma condição feminina diferenciada, por cor.

Enquanto mulheres brancas partem de uma visão de que "mulher é sempre mulher" (ensino fundamental), para atingir uma visão de conquista de maior autonomia ( nível superior), mulheres negras (ensino fundamental) partem de uma visão de pouca liberdade, expressa na dificuldade de ir e vir e no desejo de ampliar o espaço da rua como espaço de lazer, além de trabalho, para uma visão de liberdade na conjugalidade (nível superior); diferente da mulher branca, que aponta para conquistas no mercado de trabalho e de outros espaços. Enquanto mulheres brancas visam à vida pública, mulheres negras visam à vida privada. Considerando as diferentes histórias de mulheres negras e brancas e constatando que mulheres negras têm uma história de vida pública, inscrita em trabalhos forçados e desqualificados, podemos pensar que estas partem para organizar sua vida privada como tarefa histórica.

Se pensarmos, como SCOTT (1991), que a primeira instância de articulação do poder é a relação de gênero, a mulher negra que, 
historicamente, sofreu a tripla discriminação (raça, classe, sexo) está problematizando o poder, nesta primeira instância de poder, e, desta perspectiva, sinaliza para uma condição e exercício diferenciado da liberdade. É apresentado, no capitulo 10, como essa vivência é marcada pela discriminação. Essa mesma mulher negra, também, está organizada e politiza suas questões, buscando construir uma história diferente, em que 0 direito de decidir pelo seu corpo, uma bandeira feminista, passa pela mudança dos padrões de relações de gênero, que historicamente se dão em uma dinâmica diferente das mulheres brancas.

\subsubsection{O Casamento}

O casamento faz parte do conjunto das instituições sociais, que engendram distinções de gênero, eficazes no controle, na produção e reprodução social. Na perspectiva de FOUCAULT (1984), a instituição do casamento é um espaço privilegiado de controle da sexualidade, encerra teias discursivas (saberes constituídos) sobre o sexo, que é regulado por meio desses discursos úteis e públicos, e não pelo rigor da proibição do mesmo. A sexualidade, encerrada no casal legítimo e heterossexual, que gera uma reprodução (sexual e biológica) também legítima, como uma espécie de efeito colateral, multiplica-se em sexualidades "periféricas" a esse casal legítimo. Ao se multiplicar, constrói um domínio a ser conhecido, algo que se quer conhecer, tornando-se, segundo FOUCAULT (1984), a busca da verdade sobre si.

A intimidade, dentro de uma concepção de modernidade, configura um contexto de maior reflexividade do eu, implicando uma noção de autonomia, que se define como uma dada capacidade de auto-reflexão e auto-determinação dos indivíduos. A reflexividade do eu, nesta perspectiva, dota os indivíduos de maior capacidade para "deliberar, julgar, escolher e agir, diante de diferentes cursos de ação possíveis" (GIDDENS 1993, p.202). 
A possibilidade de construção de uma realidade, em que haja direitos sociais e políticos que permitiriam o desenvolvimento dessas capacidades é, no pressuposto da modernidade, apresentada por GIDDENS (1993) como o caminho pelo qual o espaço da intimidade se transformaria em um espaço de expressão de uma dada sexualidade plástica, ponto de ligação entre o corpo, a auto-identidade e normas sociais (GIDDENS 1993,1996). A sexualidade plástica, livre da relação direta com a reprodução (biológica), colocar-se-ia como um traço da personalidade dos indivíduos, em um contexto de ritos mais igualitários.

O elemento ordenador das relações sociais, neste caso, é a confiança ativa, em razão do maior nível de reflexividade do eu e maior nível de diálogo entre os pares, o que viabilizaria a construção de relações sociais com base em um comprometimento e reconhecimento de obrigações mútuas, que perdurariam ao longo do tempo, permitindo a restauração da solidariedade em bases não coercitivas, porque são orientadas por relações entre indivíduos autônomos, ou seja, livres da violência. A confiança ativa, nessa concepção, permite a construção da solidariedade, requerendo dos indivíduos uma constante discussão sobre os parâmetros, pelos quais se guiam. Trata-se de uma política de vida, no âmbito das relações interpessoais, que substitui o uso da força pelo diálogo. A reflexividade e a confiança ativas formam a base de uma política gerativa que, dessa perspectiva, possibilitaria aos indivíduos uma atuação mais livre e autônoma num espaço de democracia dialógica, que envolve a vida pessoal - relações de parentesco, de gênero, de amizade - ordenada por meio do diálogo, e não pelo poder, pelo comprometimento mútuo e pela imposição de regras no espaço da intimidade, que, em um contexto moderno, seria, conseqüentemente, um espaço de construção da solidariedade de gênero, por exemplo.

Num contexto ideal de modernidade, indivíduos desenvolvidos, afetiva e emocionalmente, propiciariam o fortalecimento de uma democracia 
dialógica e, por conseguinte, de uma política gerativa, ou seja, produzida por indivíduos autônomos (GIDDENS 1993, 1996). Em uma sociedade mais inteligente e bem informada, sobre si e sobre os outros, e mais igualitária, os papéis sexuais e sociais não estão pré-fixados, ao contrário, são objeto de discussão e negociação. Casais que são capazes de desenvolver um processo de negociação são, também, mais capazes de implementar um tipo de democracia dialógica, em que disputas e contendas sejam resolvidas por meio do diálogo, e não por meio da força física.

Homens e mulheres radicalmente modernos, argumenta GIDDENS (1993, 1996), negociam seus papéis e esta negociação só é possível se houver um grau de flexibilidade dos pares, com relação aos papéis sexuais e sociais de ambos. 0 oposto do diálogo, nessa perspectiva, é a violência. E a causa desa violência é localizada no "fundamentalismo de gênero", ou seja, em uma fixidez naquilo que seja masculino e feminino, e suas atribuições, tratando-se de um tipo de conservadorismo, que leva a uma rigidez a impedir a construção de uma relação mais reflexiva e compartilhada, característica da modernidade.

Finalmente, nessa perspectiva, é no espaço da intimidade que devem se processar transformações sociais que garantiriam o exercício do direito e da afetividade e, ao mesmo tempo, essas mudanças só são possíveis em locais onde haja direitos sociais, na visão de GIDDENS (1993). Em conclusão, essa modernidade só é possível, onde haja sujeitos em pleno gozo de seus direitos sociais e políticos.

Deste modo, a intimidade, no contexto da modernidade, seria a arena da vida humana a ser democratizada, e o espaço onde se espelharia a ausência de democracia no domínio público. Nos pressupostos da modernidade, a intimidade é um campo de experimentação e de vivências afetivas possíveis em um espaço democrático, em que coexistem vários 
direitos sociais e privados, em suma, é um campo de exercício do direito à afetividade (GIDDENS 1996).

Se uma sociedade inteligente é, em princípio, formada por indivíduos bem informados sobre si próprios (em sentido amplo) e sobre os outros, como aponta GIDDENS (1996), refletir sobre os "outros" e sobre a situação/condição/estrutura de vida nos auxilia a compreender a "nós" mesmos, como agrupamento coletivo.

De uma outra perspectiva, para que se realize uma união conjugal, existem alguns determinantes bem específicos, como disponibilidade de parceiros. Através do trabalho de BERQUÓ (1986), podemos observar que a conquista de um parceiro, que atenda às exigências individuais, depende, em parte, da disponibilidade deste e, por outro lado, das condições sociais e culturais que permeiam a escolha de um parceiro. 0 trabalho referido aponta a redução das chances de casamento das mulheres, após a idade de 35 anos, como reflexo do mercado matrimonial que contém, nessa fase, um excedente de mulheres em relação aos homens. As causas que levam à configuração desse quadro são: a queda da mortalidade feminina por parto, gravidez ou pós-parto e aumento da mortalidade masculina por mortes violentas, ou seja, uma mudança nas condições de vida das mulheres. Aquelas mulheres, que conseguem se unir com homens de menor idade, formam um grupo de exceções.

A subpopulação de mulheres brancas, comparada à subpopulação preta, obteria maior sucesso nas disputas por um parceiro. 0 que acontece é que, mesmo contando com um número maior de homens no seu grupo étnico/racial, mulheres pretas levam desvantagem em relação às brancas. Homens negros, por esta via, teriam preferência por mulheres brancas, em detrimento das negras. As desvantagens da mulher negra, no mercado matrimonial, devido ao componente racial, levam, obviamente, a uma desigualdade na dinâmica do mercado matrimonial, dessa dinâmica resultam 
arranjos conjugais ou a falta de um arranjo que, de certa maneira, influem na formação de novos núcleos familiares, segundo BERQUÓ (1992).

Ambos os grupos, de mulheres negras e brancas, pensam na monogamia como formação essencial do casamento, embora haja um caso de mulher branca questionar o casamento como sendo, necessariamente, monogâmico. Isto implica determinada moralidade, que pode ser descrita, como cristã. Vale destacar que o casamento, no grupo entrevistado, apresenta-se como um evento, na sua maioria, entre iguais, do ponto de vista de raça e de condição social.

Observa-se que, ao ingressarem em grupos de escolaridades diferenciadas, mulheres tendem a assumir o discurso pertinente ao seu grupo. Isso significa que mulheres negras de ensino fundamental têm, como as brancas de mesma escolaridade, um discurso mais conservador e rígido, com relação à união conjugal, enquanto negras de nível superior, assumem, como as brancas do mesmo nível, um discurso liberalizante, em que se observa uma multiplicidade de formas de viver a conjugalidade, ainda que todas monogâmicas.

Observando os discursos, por categorias de níveis de escolaridade, percebe-se que mulheres, de ensino fundamental e médio, confrontam-se com um modelo de união mais convencional e com papéis sexuais mais rígidos, enquanto mulheres de nível superior apresentam formas de união mais flexíveis, quanto à definição de papéis sexuais na relação e quanto à forma de casamento possível.

SOUZAS e ALVARENGA (2002), ao analisarem concepções sobre casamento de mulheres de baixa renda, em São Paulo, observam que são várias as estratégias que levam a uma união conjugal e que, ao ser estabelecida, seja qual for a modalidade, a monogamia e fidelidade conjugal são pressupostas e desejadas, embora a infidelidade seja considerada uma 
tradicional prática masculina. 0 papel do provedor demarca, profundamente, o modelo de família e a união conjugal nas camadas populares.

No caso de uniões conjugais, de mulheres de nível superior, percebe-se que as transformações sociais engendraram mudanças no comportamento social com relação ao casamento. Trata-se de uniões que se caracterizam por serem mais reflexivas, nas quais o casal se permite maior flexibilidade dos papéis sociais, socialmente previstos como masculinos e femininos (GIDDENS 1993, 1996). Onde há uma pluralidade maior, com relação às formas de união e acordos possíveis. A análise da trajetória, em direção à consolidação da união estável e com filhos, permite observar a existência de maior flexibilidade dos pares frente à união conjugal. Pertencer a um determinado segmento social significa reproduzir um determinadao discurso, que legitima o seu pertencimento no grupo. Sendo assim, os discursos de mulheres negras e brancas não diferem quanto ao que pensam sobre o casamento. 0 caratér que assume a união conjugal, mais rígido ou mais reflexivo, adequa-se ao padrão de comportamento de determinado segmento. Esta possibilidade de reprodução social foi analísada por BOURDIEU (1992), que caracteriza um mercado de trocas simbólicas. 0 casamento, em certa medida, participa desse nivel de troca e assume 0 caráter mais rigido (e atualmente em crise) para mulheres de escolaridade fundamental e, mais reflexivo, para aquelas de escolaridade superior.

Mulheres de ensino fundamental

Associada à incompreensão e dificuldade de diálogo, mulheres negras de ensino fundamental descrevem, em termos de perspectivas, o casamento como uma instituição que está em crise. A razão da crise estaria nas atuais transformações das relações conjugais e de gênero, nas quais as mulheres desafiam muito mais os limites impostos a elas por seus companheiros. GIDDENS (1993) apontou para o ambiente de crise e de transformação a que as relações estão passando. Existe a possibilidade de 
pensar, através do depoimento apresentado a seguir, que há um processo de transformação em marcha e que modificará as relações de gênero, mesmo as consideradas mais tradicionais.

Hoje em dia o casamento está difícil. Bem difícil. Casamento, hoje em dia, p'ra dar certo, você tem que gostar muito. Porque hoje em dia o pessoal não quer compromisso sério. Está difícil. Quem tem um casamento antes, bem antes, está difícil p'ra segurar, e quem está casando, agora, não está dando certo. Porque está tendo muita incompreensão. Muito aquela disputa. Porque o homem acha que a mulher tem que ser submissa a ele. As mulheres não querem ser submissas aos homens. Aí, o casamento não está dando certo, não (Eliane, mulher negra, ensino fundamental, laqueada).

Mulheres brancas, com ensino fundamental, corroboram a idéia de que a instituição casamento está fragilizada, agregando a idéia de que a prática da infidelidade conjugal e ausência de cumplicidade, entre os casais, estão promovendo a dissolução dos casamentos

Hoje em dia? Hoje em dia eu acho besteira casar. São raros os casos que você fala assim "esse pode casar". Porque é como eu falei anteriormente: hoje, a traição é uma coisa assim tão fácil de se fazer e tão conveniente, que é besteira casar (Gorete, mulher branca, ensino fundamental, Laqueada).

O casamento é uma modalidade de relação, que está passando por transformações, constatadas em nível de realidade, através de crises no âmbito das relações de gênero e, mais especificamente, na conjugalidade. 
Mulheres de ensino médio

A visão de mudança, que se apresenta no conjunto das mulheres negras, de ensino médio, segue o mesmo padrão de discurso das mulheres de nível fundamental: descrevem relações afetadas por conflitos conjugais, percebem o casamento atual como um tipo de relacionamento vulnerável a separações, e que as transformações sociais em pauta estão afetando a conjugalidade.

Bom, eu tava falando que, hoje em dia, as pessoas não tão levando a sério o casamento, não é? Eles tão casando por casar; já tão casando pensando na separação. Então, não tão casando p'ra constituir família... e se, as vezes, tem filho, eles não respeitam. Se tiver que separar, separa mesmo. Então, eu acho que eles não tão... o pessoal não tá respeitando... os jovens de hoje em dia, não tá respeitando 0 casamento, não (Amanda, mulher negra, ensino médio, histerectomizada).

Diferenciando-se de mulheres negras, de ensino médio e fundamental, e de brancas, de ensino fundamental, o discurso da mulher branca, de escolaridade média, apresenta a visão de transformação da relação conjugal, e não de crise. Essa perspectiva aparece sintetizada no discurso de Carla. A mulher questiona a submissão de gênero:

Eu acho que depende do que as pessoas que estão se relacionando estão dispostas a viverem juntas. Eu acho que está meio complicado, porque antigamente se tinha os papéis bem definidos e hoje em dia não, hoje em dia, porque o homem vai mandar em você? Entendeu? Por que você tem que fazer determinadas coisas? Eu acho que, as coisas todas acabam muitas vezes atrapalhando o relacionamento. Coisas que eu acho importantes, um processo de evolução, porque 
que eu tenho que ser submissa[a] alguém? Eu acho que nem a mulher tem que ser submissa ao homem, nem o homem à mulher. Acho que é meio a meio e acho que chegar nesse ponto é que é o complicado (Carla, mulher branca, ensino médio, marido vasectomizado).

A visão de crise prepondera nos discursos de mulheres negras, de ensino fundamental e médio, e de mulheres brancas, de ensino fundamental. Já mulheres brancas, de ensino médio, visualizam uma situação de transformação na conjugalidade, que não comporta mais papéis rigidamente fixados. Possibilidade que aponta para um processo de assimilação de um padrão de comportamento mais moderno, no sentido desenhado por GIDDENS (1993), pode ser verificado entre mulheres de escolaridades superiores.

Mulheres de ensino superior

A visão que a maior parte do conjunto de mulheres negras, de nível superior, tem em relação ao casamento, é a de que se trata de uma relação, em que é possível compartilhar, havendo cumplicidade e, sobretudo, flexibilidade entre os pares. Diferentes modalidades de relacionamento sobrepõem-se à relação tradicional de casamento. É válido pensar-se em maior reflexibilidade e engajamento num tipo de relação em que é possível a individualidade, sem tantos conflitos com a conjugalidade. Melhor dizendo, é possível viver a dois, sem que um ou ambos se anule(m) na relação:

Casamento é: cada um organiza o seu do jeito que acha melhor. Hoje em dia não tem muito definido. Porque eu organizei o meu do meu jeito. As outras pessoas. Não tem mais assim exato, as pessoas casam por pouco tempo, poucos casam por mais tempo. Casa, mora 
separado (Roberta, mulher negra, ensino superior, camisinha masculina).

Mulheres brancas, de nível de escolaridade superior, revelam, por meio do discurso, que a conjugalidade é uma vivência complexa, e que exige inúmeros arranjos que possibilitem o casamento de se realizar. As relações conjugais tradicionais são questionadas por algumas mulheres e mantidas por outras, em uma busca de companheirismo e cumplicidade. A interlocutora, abaixo, revela a própria trajetória rumo à consolidação da união conjugal. Considera que "a conjugalidade moderna" permite comportar várias etapas, até a consolidação da união estável.

Eu acho que casamento é uma faca de dois gumes. Eu acho que tem seu lado muito bom, mas tem seu lado muito ruim. E assim eu acho que é legal ter um companheiro, ter uma pessoa, dividir. Sabe, mas por outro lado eu tenho uma coisa, que é muito minha, e que eu acho que acaba se sobressaindo. Como, por exemplo, no caso do meu relacionamento, eu fico sem encontrar com o F. três dias na semana. A gente não se vê porque ele trabalha fora. Eu acho isso uma delícia. Sabe essa... Não quando ele está fora, mas quando eu vejo ele, quando eu encontro com ele. Aí é que eu vou ver que ele ficou fora, que eu senti saudade, que eu gostei dele ter voltado. Então é um negócio assim ..a impressão que dá, tem que estar longe para sentir falta, para valorizar, é um pouco isso. Sabe, então, às vezes eu acho muito legal viajar sozinha, tanto com o filho, como com o marido. Acho isso importante, dar uma trégua. Porque é muito difícil o cotidiano, o dia a dia, não é fácil, 
todo santo dia. Eu falo isso porque eu vivi um tempo com o $F$, ele numa casa e eu na minha e era muito legal. Bem, isso de relacionamento. Ai a gente viveu, ele veio morar comigo porque a casa era maior, ai tinha mais uma amiga que morava comigo, e ele veio. Então, a gente viveu muito tempo em quartos separados, ele tinha um quarto eu tinha o meu e a C. tinha o dela. Era uma república que foi deixando de ser uma república cheia. Então, a gente ficou muito tempo junto vivendo em quartos separados. Porque eu achava muito interessante, já que não podia ter casas separadas, quartos separados era uma boa saída. Já alivia. Então, na verdade, eu acho que é assim é legal, mas desgasta. [O que você acha de bom?] De bom eu acho que é o companheirismo, acho que você ter uma pessoa que você possa dividir. Porque tem uma questão que pesa que é a questão financeira, que é você pagar dois apartamentos. É melhor você pagar um apartamento e ficar dividindo. Eu tenho essa questão financeira, que eu acho que a maioria das pessoas... igual a mim que não se preocupa em casar, vestir de noiva, aquela coisa. [Você não fez tudo isso?] Não fiz e minha mãe não acreditava. Minha mãe falava: "Suzete eu não acredito que você não tem vontade" Eu nunca tive vontade. Jamais assim pensei em vestir um vestido de noiva. E eu acho engraçado quem tem vontade. Acho isso diferente. [E você casou normalmente?] Casei no civil. Fui lá no juiz e assinei (Suzete, mulher branca, ensino superior, DIU).

Dentre os depoimentos de mulheres, de ensino superior, é interessante observar, no de Solimar, como ela coloca algo que está 
pressuposta em todas as relações, que é a monogamia absoluta. Nenhuma das mulheres questiona o relacionamento neste nível, ao contrário, enfatizam uma preocupação por manter esta condição na relação conjugal.

Bem, eu acho o casamento uma coisa meio assim, você não quer separar, então você fica, faz uma novelinha... eu acho tudo meio borocoxô. 0 meu e os outros. Não borocoxô, em relação às opções que a sociedade me dá hoje, sólidas, mas pensando livremente... Pensando livremente sobre a vida, em outra sociedade, eu acho o casamento uma coisa muito... chata. Casamento é monogâmico, ainda que existe uma .,eu e o I nunca sentamos p'ra discutir a monogamia ou a não monogamia, entendeu? Eu sei que desse ponto de vista nós temos... alguma coisa construída, que acabou sendo monogâmico, mas não é uma coisa que é uma regra, fundamental, acabou sendo. Agora, é monogâmico. Tem problema se não for, entendeu. Tem. Tanto p'ra mim, ah, não legal, vou sair, me divertir, mas...então eu olho os casamentos um pouco assim, sabe, xôxo. E isso cria algumas tristezas nas pessoas (Solimar, mulher branca, ensino superior, camisinha masculina).

O casamento, para as mulheres, foi, por muito tempo, a única forma de conquistar uma identidade social (PATEMAN 1993). Isto se reflete no discurso de mulheres de nível fundamental e negras, de ensino médio, e, em menor proporção, no de mulheres de nível superior. A monogamia absoluta está presente no discurso das mulheres, como forma organizativa da vida sexual. Isto é especialmente relevante para pensar as escolhas sexuais e reprodutivas das mulheres entrevistadas. Por meio do casamento monogâmico, forma-se o casal romântico dos tempos modernos (GIDDENS 1993). Os filhos dessa relação, na perspectiva modernizante, deveriam ser cuidados por pais e mães. Entretanto, historicamente, a mulher foi relegada 
ao mundo privado, como foi mencionado anteriormente, e a maternidade ocupou um espaço importante de suas vidas, como pode ser visto a seguir.

\subsubsection{As maternidades}

A mulher rousseauniana, como refere BADINTER (1985), é sofredora e feliz, tem no sacrifício a fonte de redenção. É no arquétipo de "boa mãe" que a ideologia do devotamento e do sacrifício se realiza, e apregoa que não é "boa mãe" quem quer, é "preciso toda uma preparação espiritual e cristã para admitir a necessidade de sacrifício e esse esquecimento de si eleva a boa mãe acima da condição humana, espontaneamente egoísta" (BADINTER 1985:271). A mulher, por esta visão, adquire um caráter de santidade, devido ao imenso sacrifício em uma missão obrigatória a todas as mães. 0 devotamento sem limites é a forma pela qual Eva (figura do pecado) transfigura-se em Maria (Virgem Santíssima). Dentro dessa ideologia, o trabalho feminino é a fonte de desestruturação da família. 0 pai tem um papel secundário, é responsável pelo sustento dessa família, ao lado do Estado. Dentro desta visão, a mulher que trabalha, o faz por necessidade, mas tem no papel de mãe a sua maior devoção. A mulher intelectual e que faz carreira é, por essa ideologia, criticada.

A maternidade apresenta uma grande importância na vida das mulheres entrevistadas, que têm, junto aos parceiros, de administrar sua capacidade reprodutiva e enfrentar os desafios que a maternidade coloca. Neste contexto, nem sempre, a gravidez é bem-vinda e as possibilidades de aborto são seguras.

E, em se querendo a gravidez, outros obstáculos devem ser enfrentados para uma maternidade segura. Além, é claro, dos desafios para o cuidado da criança. Com a maior inserção de mulheres no mercado de trabalho, cresce a necessidade de uma rede de proteção social e a transferência da responsabilidade pela maternidade a outras pessoas da 
família ou rede social (COSTA 2002). Nota-se, entretanto, que mulheres têm posições diferentes frente à maternidade, expressando, de certa forma, maior ou menor dificuldade na vivência da maternidade.

Ao buscarmos observar, no discurso dessas mulheres, como elas vivenciam a maternidade, constatamos que algumas mulheres negras e brancas qualificaram a maternidade como um aprendizado, uma profunda transformação na vida da mulher, outras, como uma dádiva divina, além de ser sugerido como um momento de extrema feminilidade, no qual a mulher se realiza em sua plenitude.

\section{A maternidade da mulher negra}

Mulheres negras, a seguir, apresentam a idéia de que existe um certo dom para ser mãe, ou seja, uma qualidade natural ou inata, que não é conferida a todas as mulheres. Este dom implicaria na capacidade de doação, desvelo e cuidado com os filhos. Segundo GIDDENS (1993:111), “A invenção social da maternidade pressagiou e deu forma concreta à idéia de que a mãe deveria desenvolver um relacionamento afetuoso com o filho, relacionamento este que confere um peso específico às necessidades da criança".

Acho uma coisa muito bonita, acho que... toda mulher devia... ter, assim, a dádiva... sabe?... a graça de ter um filho, porque é uma coisa maravilhosa. Eu, se pudesse, teria os... todos eles que eu... que eu não tive. Seria muito bom (Amanda, 48 anos, mulher negra, ensino médio, histerectomizada).

[E como foi a maternidade, na sua, como você se sentiu?] Ah eu me senti bem, tanto que eu tinha o dom de ser mãe, tanto que eu abdiquei de um monte de coisas quando eles eram pequenos, para ficar com eles, ah de sair à noite, de sair para gandaia, uma coisa 
que eu gostava de fazer de vez em quando, faço muito de vez em quando, hoje em dia, e aquilo que eu falei me deu ... me fez ver a vida de outra forma. Eu não fiquei só pensando em mim, mas pensando nos meus filhos, no coletivo também (Hortênsia, mulher negra, ensino superior, laqueada).

Dentro dessa perspectiva de maternidade, como um dom, é que aparece a idéia de que a maternidade promove transformações na vida da mulher e é capaz de determinar rumos e resultados à sua vida

A força que tem a maternidade na vida da mulher pode ser ilustrada na fala da mulher negra, a seguir. Percebe-se, ao final do discurso, que a maternidade equivale a uma perda da individualidade, ao mesmo tempo em que se assume uma nova identidade, a de mãe e cuidadora. BADINTER (1985) apresenta, em sua reflexão, como a mulher foi seduzida para ocupar este lugar de cuidadora. Era prometida a igualdade da mulher ao homem, na relação conjugal, à medida que ela fosse se revelando uma boa mãe. É interessante como algumas mulheres negras assumem esse discurso, o da maternidade, como um dom. É uma concepção de maternidade, que inclui habilidades e capacidades, não pertencentes a todas as mulheres. Isto significa que, ser mãe não é um destino biologicamente traçado para todas as mulheres, mas é um dom que algumas mulheres têm e outras, não. 0 fantasma da esterilidade está por detrás do discurso de uma das mulheres. Percebe-se, na fala da interlocutora, que a maternidade é super valorizada e até mesmo endeusada.

[É... E como... como que você... o que você acha, assim, da maternidade p'ra mulher? 0 que você acha que é a maternidade p'ra mulher, assim?] Ah, é uma coisa muito boa, não é?, o dom... é um dom que Deus deu p'ra gente, não é? Ah, é tão bom você falar assim: "eu sou mãe". É uma coisa tão... maravilhosa. Quando eu fiquei... 
fiquei sabendo que eu tava grávida, tanto faz do primeiro como dos outros, p'ra mim, sabe?, eu me senti a mulher mais realizada do mundo, porque é tão bom. Eu tive um caso lá de uma... de uma tia minha que era louca p'ra ser mãe, foi até pros Estados Unidos - que ela tem condições - p'ra fazer tratamento, mas ela não pode. Então, é uma coisa, você sabe, é uma coisa divina... você tá sabendo?... é um pedaço de você que tá saindo... [...] é um pedaço de você, é uma coisa maravilhosa. A palavra mãe é uma coisa tão forte; é uma coisa assim que... Mãe... não tem... não tem palavra. Mãe é tudo. Não é? Primeiramente, Deus. Mas mãe é tudo, depois de Deus é tudo. Então é muito bom; é muito bom. E como que você vê, assim, a...a... no seu caso, não é?, como que... o que a maternidade... mudou na sua vida? . Tudo. Eu era... eu era uma pessoa amarga, eu era uma pessoa assim... como posso the explicar?... Eu não dava ligança p'ra nada da vida; não ligava p'ra nada da vida. P'ra mim... tanto faz, tanto fez. Tava tudo bom, tudo maravilhoso. Depois que eu fui ter... fui... depois que eu fui mãe, eu aprendi a ter responsabilidade, aprendi a me amar, que eu não me... eu não me amava também, não me dava tanto valor, aprendi a ver as coisas de outra maneira, com mais clareza, com mais simplicidade, entendeu? Eu era egoísta... Depois que eu pa[...], tive meus filho, eu comecei a ver como era doce, como era bom... entendeu? Apesar que eu ainda sou egoísta porque eu quero eles só p'ra mim. Eles não são meus. Eles vão ser do mundo. Mas eles só são p'ra mim, é só meu. Então, p'ra mim foi... mudou muita coisa na minha vida. Eu aprendi a ser uma mulher mais... mulher mais feminina; mais tudo. Eu não era... eu era muito egoísta. Muito... não ligava p'ra... p'ra vida. Eu aprendi a dar valor p'ra vida... à minha mãe também; aprendi a dar valor a mais p'ra minha mãe; porque eu achava que a minha mãe queria... tipo assim: queria me prender, assim, por mal; [...] essas coisas. E eu aprendi que não, a mãe quer proteger... mãe, ela quer proteger, ela não quer o mal pro 
filho; uma mãe nunca quer o mal... o filho pode ser o que for, mas uma mãe quer proteger... por mais que o filho apronte ou não dê valor, mas... Eu aprendi a dar valor p'ra essas coisas; eu aprendi muita... muito, depois que eu fui mãe. A maternidade me ensinou muita coisa. Muita mesmo (Sabrina,mulher negra, ensino fundamental, extraiu as trompas).

Condições para a realização de uma maternidade, segura e planejada, nem sempre, estão à disposição das mulheres. Na maioria dos casos, a maternidade representa um sacrifício, principalmente para as mães que zelam pelos filhos. As dificuldades apresentadas, de forma sintetizada na fala de Luisa (mulher negra), acenam para o quadro de obstáculos que a mulher deve enfrentar para realizar a maternidade desejada.

Muito difícil, por isso a gente já conversou, porque algumas mulheres fazem a opção de terem o filho sozinha. 0 que eu acho ato de coragem e acho que é viável também. Só que é difícil, todo mundo sabe. E algumas mulheres têm o filho dentro de um casamento e também são sozinhas porque, nem sempre, o companheiro participa da educação e da criação. Então, acho que é difícil e acho que, com o passar do tempo, tem ficado mais difícil a maternidade. Porque a mulher tem que sair de casa, tem que trabalhar o dia inteiro, com quem ela vai deixar os filhos dela? Existem creches, existem escolas e elas deixam, mas assim, imagino que não deve ser uma coisa muito fácil, também porque, assim, aquela criança que acorda 6 horas da manhã, que sai com a mãe e que volta 8 horas, e que a gente sabe de casos que são assim. A criança fica o dia inteiro na creche na escolinha e volta 8 horas da noite p'ra casa, eu acho que é isso, não seria um ritmo de vida normal para uma criança. Eu acho que é um ritmo de vida que foi imposto à criança. Mas isso não é um ritmo de 
vida adequado p'ra uma criança recém-nascido. Eu acho, é difícil. Sabe! (Luisa, mulher negra, ensino superior, camisinha masculina).

A maternidade da mulher branca

Quando a maternidade acontece na vida da mulher, promove mudanças que, nem sempre, foram esperadas, por isso a gravidez planejada é desejada e, em algum sentido, cultivada como ideal. A maternidade, que ocorre na fase da adolescência, é vista como um problema, em função da responsabilidade que a menina-mulher passa a ter, para as quais ela é pensada como despreparada e inexperiente. Sobretudo, a maternidade fora do casamento é apontada como um problema, pois, em outras palavras, atropela uma fase da vida em que a menina-mulher deveria estar estudando, preparando-se para uma vida futura. A gravidez, na adolescência, é questionada e encarada como um descuido das meninas-mulheres, que não lançaram mão da prevenção.

[E para as mulheres em geral, o que representa isso de ser mãe?] Olha, eu acho que a pessoa tem que estar a fim de estar grávida. Quando ela vem, sem que a pessoa espere, por exemplo, na adolescência, a maternidade já não é tão bem vinda. A pessoa não faz a maternidade... aí, vira um estorvo, não vai querer a maternidade naquela situação. Mas se está madura, se ela está... se ela casou, ela quis estar grávida, então aquilo vai bem, ela quis ficar grávida ( Lucia, mulher branca, ensino fundamenta, laqueada).

Para muitas mulheres, ter um filho representa a realização de um ideal de família, que se completa com a presença dos filhos. As crianças, então, cumprem um papel social de formação de um lar. De certo modo, o filho promove mudanças na relação do casal. Entretanto, a maternidade 
adquire uma certa relatividade no discurso de algumas mulheres e, nem sempre, é maravilhosa, como referem outras. É uma transformação que, inegavelmente, ocorre.

Ah, porque me deu... me baixou um Exu tranca rua (risos), que eu achava que eu não tinha que ter tido filho, não queria mais saber de filho, de marido, queria sair de casa, ir p'ra balada, essas coisas, e eu achava que eles estavam me atrapalhando e... separei dele assim, achava que ele que era o culpado de tudo. Passei um ano e meio querendo ficar com ele e sem ele. Aí, depois a gente voltou e estamos juntos até hoje. Mas olha, foi um Exu tranca rua mesmo que baixou em mim naquela época, nossa, foi um horror, nossa, era um horror. Por isso que eu falo que p'ra ter filho, hoje, você tem que ter uma estrutura já (Amália, mulher branca, ensino médio, marido vasectomizado).

Maternidade da mulher negra e branca

Embora algumas mulheres negras, de nível superior, possam expressar a concepção de maternidade como dom, é neste grupo que aparece a ruptura com essa concepção, para uma nova idéia mais libertária de maternidade, como uma forma de aprendizado, enfim, como uma relação a ser construída. A maternidade adquire um outro significado, é muito mais caracterizado como um processo de aprendizagem. A idéia de maternidade, como dom, como capacidade inata a algumas mulheres, é abandonada pela idéia de aprendizado.

A maternidade torna a vida das mulheres diferente do que era antes. Isso é apontado por diferentes mulheres entrevistadas, mas a concepção de maternidade se altera nos diferentes discursos. Para a interlocutora, a seguir, a maternidade é um aprendizado que implica 
estabelecimento de uma relação com o outro, o(a) filho(a). 0 estranhamento inicial, da mãe com o bebê, aponta para uma relação de alteridade, que implica constituição de dois sujeitos que, a despeito das práticas sociais e culturalmente estabelecidas, acerca da maternidade, constróem uma relação particular. A maternidade desnaturalizada, na vivência dessas mulheres, remete para as reflexões de BADINTER (1985), que sinaliza o mito do amor materno, como uma construção sócio-histórica.

Olha, vou falar uma coisa estranha: quando nasceu meu primeiro filho, eu não sentia nada de maternidade. P'ra dizer a verdade, verdade, eu olhava a criancinha, era uma criancinha. Acho eu fui aprendendo a ser mãe. Eu não sentia essa coisa "Ah mãe". Foi a relação mesmo. Eu até me cobrava. Olhava assim, não tinha um sentimento. Eu tinha, sim, que cuidar. Aí, depois de cuidar, você vai conhecendo a criança, a criança vai conhecendo você. Vai criando uma relação afetiva. Mas, sinceramente, sinceramente, eu não sentia nada no começo (Roberta, mulher negra, ensino superior, camisinha masculina).

Este aprendizado cotidiano da maternidade implica descobertas de emoções, não experimentadas antes. Como assinala BADINTER (1985), é na relação com o bebê que se descobre a maternidade e esta é a vivência que relata Sonia:

Eu acho que ser mãe é um aprendizado, acho que é, a gente não tem a sensação de que acerta, eu não tenho essa sensação, é uma sensação de descobrir e, principalmente, quando a gente é uma adolescente, então é uma descoberta, é um outro jeito e, ainda hoje, é uma novidade, é uma novidade; eu acho que, eu particularmente não tenho assim, aquele instinto materno, não, então p'ra mim... [Como é p'ra você esse instinto materno?] Eu não tenho isso, eu não 
tenho essa habilidade, então é, no meu caso, é uma tarefa de crescimento mesmo. [Não é uma coisa que pode vir a ser?] Não, não. No meu caso não, porque eu tenho outras coisas. É um aprendizado muito grande ser mãe, cuidar, orientar, às vezes, não ser tão prática, porque eu sou uma pessoa muito prática e nem sempre dá p'ra ser tão prática assim, tem que ser emocional e de um jeito legal p'ra ele, achar um jeito.(Sonia, mulher branca, ensino superior, marido vasectomizado).

Conforme RODRIGUES (1993), a maternidade é um fenômeno biológico, que passa por apropriação cultural e controle social. Afirma que a maternidade "está naturalmente inserida no ciclo de vida das fêmeas, mas provoca, enquanto fenômeno social, profundas repercussões na vida das mulheres, porque encerra uma dimensão simbólica, ideológica, emocional, religiosa, política e econômica, que se coloca muito antes para a gestante, que enfrenta as transformações orgânicas e psíquicas da gravidez, do que para a sociedade e o Estado, que absorverão muito mais tarde o novo cidadão" (RODRIGUES 1993:35-36)

O confronto de concepções ideológicas acerca da maternidade, do papel da mulher na sociedade e das injunções sociais e políticas, faz do dilema ser ou não ser mãe, algo para se refletir (RODRIGUES 1993).

Para BADINTER (1985: 22), o amor materno é possibilitado no contato com a criança. A "maternagem" é um processo a ser desenvolvido. Segundo a autora, "O amor materno é apenas um sentimento humano. E, como todo sentimento, é incerto, frágil e imperfeito. Contraditoriamente aos preconceitos, ele talvez não esteja profundamente inscrito na natureza feminina". Este só existe quando há o desejo, e o desenvolvimento é possibilitado ao tocar, beijar, mimar a criança. Sobre as bases do amor materno, PINHEIRO (1991) faz uma interessante reflexão sobre a obra de 
Margarete Hilferding (1991), que deu os primeiros passos para a compreensão psicanalítica do amor materno, afastando-o do caráter instintivo e inato. Esse afastamento possibilita compreender a "maternagem" como uma capacidade possível de ser desenvolvida, ou não, depende da relação que se estabelece com a criança. Essas reflexões remetem-nos à idéia de que os papéis sexuais, masculino e feminino, são construídos socialmente, assim como a "maternagem" e a "paternagem". Grande parte da literatura sobre relações de gênero leva-nos a refletir sobre as implicações sociais que decorrem da fixação de normas e valores sociais, baseados na rigidez de papéis sexuais. SCOTT (1991) volta-se para a construção de uma análise, a partir da categoria gênero, base explicativa para as desigualdades sociais entre homens e mulheres.

Em nossa pesquisa, como foi mencionado anteriormente, algumas interlocutoras negras colocam a maternidade como dom. O amor materno, diferente do fenômeno biológico de "partejar", é um sentimento humano que pode ser desenvolvido, ou não, como refere BADINTER (1985). É algo a ser cultivado nas relações humanas. Não é, portanto, algo que é inato a todas as mulheres. Há que haver condições sociais e culturais que permitam 0 surgimento do amor materno e, porque não, paterno.

Os inúmeros conflitos vivenciados por mulheres, que se propõem construir algo diferente do culturalmente estabelecido, em busca de superação da concepção de maternidade, como destino e, na tentativa de obter uma libertação de papéis, historicamente delegados à mulher -- e que, em certa medida, promovem a subjugação e exploração da mesma -devem-se, em parte, a concepções naturalizadoras da maternidade. RODRIGUES (1993) analisou várias gerações de mães e identificou discursos ideológicos, que ora valorizavam a natalidade, ora o controle da natalidade, sinalizando para a questão de que a maternidade tem um conteúdo que pode ser manipulado ideologicamente. Observando a questão, de uma perspectiva étnico racial, temos que a maternidade e corpo da mulher negra, 
no período colonial brasileiro, como apontou DEL PRIORE (1989), foi objeto de medicalização, que as afastava de práticas e técnicas de partejar de tradição africana. Uma ideologia aí se instalava para impor a obstetrícia, como forma privilegiada de atividade no acompanhamento do parto (TANAKA e ALVARENGA 1999; VIEIRA 1999)

No relato de RAGO (1987), podemos observar como a mulher foi devolvida ao lar, em um processo de disciplinarização, a maternidade, sacralizada e a mulher, entronizada como "rainha do lar". A ideologia higienista marginalizou as nutrizes (em geral amas de leite, mulheres negras) e condenou as mulheres que se eximiam do papel do de mãe.

0 fato de as mulheres negras afirmarem que a maternidade é uma dádiva, ou dom, atribui à maternidade um valor diferenciado de mulheres brancas. Trata-se de um discurso ideológico incorporado. Por um lado, indica uma naturalização da maternidade, por outro, de acordo com BERNARDO (1998), aponta para uma questão fundamental. Em um trabalho sensível de pesquisa, essa autora tece uma reflexão cuidadosa sobre a memória de mulheres negras idosas, faz sua interpretação, a partir de depoimentos orais, que nos levam a entender a formação das famílias negras. Estas eram, por força de tradição e da escravatura, matrifocais. As mulheres, com seus filhos, formavam famílias negras, enquanto os homens eram exigidos no sistema de produção escravocrata. Logo após a abolição, o novo sistema de produção cafeeiro não absorveu os ex-escravos e estes não tinham força para formar um núcleo familiar e ser o provedor. Na leitura de BERNARDO (1998), a maternidade negra requereu, da mulher, capacidade de doação e força para resistir às diferentes contingências historicamente colocadas para as famílias negras. Nesse sentido, a maternidade, como dom, apresenta-se como alternativa paras mulheres negras resistirem à histórica opressão e solidão no cuidado com os filhos. A família organizada de forma nuclear (pai, mãe, filhos) é algo recente para a população negra, enquanto a matrifocalidade ainda permanece em algumas famílias. 
A ideologia do devotamento e do sacrifício, assinalada por BADINTER (1985), presta-se, perfeitamente, ao modelo de família negra, gestada no período colonial. Centrada na mãe, esta era a responsável pela formação e educação moral do filho. A figura paterna é fraca, ao lado dessa mãe portentosa. É da mãe o principal encargo sobre o destino das crianças.

Romper com essas ideologias implica busca de superação dos modelos vigentes na sociedade e identificação de novos parâmetros, que possibilitem a construção de novos sujeitos, não pautados pelo sofrimento, e sim, pelo prazer. Tais sujeitos só são possibilitados à medida que se transformam os modos tradicionais de inserção da mulher e do negro nos diferentes espaços sociais.

Para as mulheres, de modo geral, a conquista do espaço público, como entende GIDDENS (1993), foi, de modo geral, crucial para ocuparem um novo lugar na sociedade. A flexibilidade dos papéis sexuais é uma característica das relações de gênero, que se vêem modificadas, ao longo da história. Uma certa capacidade, ou uma certa "reflexividade", como diria GIDDENS (1993), é necessária para se construírem relações mais democráticas.

No caso específico da população negra, como destaca BERNARDO (1998), a vivência da discriminação está presente na memória. A transformação das realidades adversas só é possibilitada por uma transformação da realidade étnico-racial brasileira.

6.2 I déias de negrura, idéias de brancura, na ótica de mulheres negras e brancas

Como referimos na introdução deste trabalho, cada brasileiro imagina-se como uma ilha cercada de racistas por todos os lados. Desta 
forma, pode-se dizer que o racismo é uma atitude de outrem (SCHWARCZ 1998), e que os brasileiros não se vêem, a si mesmos, como racistas.

As concepções acerca da negrura e da brancura, no entanto, têm um conteúdo simbólico e histórico bastante demarcado. A idéia de ser negro foi construída historicamente e adquiriu um caráter "demoníaco" e "exótico", passível de ser constatada na cultura ocidental. SANTOS (2002) refere que a inferioridade do negro foi ganhando terreno na cultura ocidental para, em seguida, construir-se uma ideologia de racista. As imagens "exóticas", "selvagens" e "demoníacas" foram de tal forma entranhadas em nossa cultura, a ponto de definirem uma visibilidade do "ser negro". Essas imagens têm seu impacto na dimensão psíquica dos indivíduos e construíram um imaginário de negrura e brancura que, introjetado nas experiências de discriminação e vivenciadas pelos indivíduos, nas diferentes fases da vida, fazem da subjetividade um campo, passível de ser discernível para brancos e negros (NOGUEI RA 1998).

Não se trata, entretanto, de uma somatória de desvantagens; na verdade, como assinala LOURO (1999), ser negro não corresponde a uma condição essencializada, não contém um único significado, imediatamente reconhecido por todos. "Negro" adquire diferentes sentidos políticos e culturais, em diferentes contextos. Serão sempre as condições históricas que permitirão compreender as relações de poder, constituídas no processo de submissão dos sujeitos.

\subsubsection{As mulheres negras, por elas mesmas}

As mulheres negras, nos diferentes segmentos de escolaridade, têm consciência de que o racismo está presente no cotidiano, e impacta, de diferentes formas, as personalidades. Nesse contexto, o discurso de resistência é o que prevalece nos depoimentos. 
A forma pela qual o racista atua é, sem dúvida, para minar as resistências do dominado, para que ele próprio se sujeite. Isto fica claro nas análises sobre a ideologia do branqueamento, realizadas por DOMINGUES (2002). Nesse sentido, o sentimento de negritude, aqui exposto, revela uma compreensão de que o racismo exclui as pessoas, de direitos e da sociedade. o caráter estético é lembrado, e ícones, como a cor da pele junto com a textura do cabelo, compõem a visão de negrura.

A mulher negra, em destaque, revela uma visão, da qual faz parte a auto estima, o auto-elogio, como mecanismo de afirmação positiva. A visão de negrura, inversamente à emitida socialmente, é positiva, sugerindo uma concepção de beleza negra, ao mesmo tempo em que a miscigenação aparece, na figura da mulata, para obscurecer o discurso.

Ah, bonita, maravilhosa, educada, chique, a pele maravilhosa, invejável... porque... não precisa tomar sol, não precisa, entendeu? Então, a pele negra é muito bonita... sem, sem... sem racismo, a pele negra é bonita, é uma... é uma pele até invejada, sabia?... as mulatas aí são tudo. Então, é... a... 0 o... a pele negra p’ra mim é uma pele bonita, uma coisa chique, uma coisa que muita gente queria ter, entendeu? É o que eu acho, não é? E, como eu sou mulher, então, adoro a cor negra (risos) (Sabrina, mulher negra, ensino fundamental, extraiu as trompas).

A realidade da discriminação, especialmente no mercado de trabalho, está presente no cotidiano das mulheres e a visão de negrura que perpassa é a da dificuldade, da desvantagem, em relação à brancura.

[E... o que você acha que é ser uma mulher negra hoje em dia? Como você definiria isso?] Difícil, não é? Tá sendo difícil p'ra muitos. Eu não posso falar muito porque eu tô dentro de casa, tô sem 
trabalho fora, mas eu percebo, por exemplo, no meu... na minha família, eu tenho cunhada que... tem um cargo bom, mas ela... demorou muito p'ra conseguir isso, depois de muito tempo, ela conseguiu um bom cargo na firma onde ela trabalha, então, é uma vida de muita luta, entendeu? Tudo é muito difícil, é mais difícil p'ra mulher negra. Tudo, não é? (Amanda,mulher negra, ensino médio, histerectomizada).

0 desafio de ser mulher negra, em um país que nega possibilidades e discrimina, é grande, mas a visão de negrura não está enredada na visão pessimista e fatalista, pelo contrário, é uma fonte de força para a superação de obstáculos.

Olha... é, assim.... é ser... p'ra nós, mulheres negras... é... posso dizer, sei lá... um desafio... tiro por mim, porque eu nunca pensei em ficar no meu canto, me olhando e dizendo sou negra, tenho que contentar com uma posição assim, ou com um lugar...entendeu?... então... eu, p'ra mim... como mulher, ser negra é... me dá mais força, mais coragem, entendeu? ... de entrar e sair, sabe, de... de qualquer lugar e... de estar sempre me... sempre melhorando, sempre... procurando crescer... eu vejo assim... (Marta, mulher negra, ensino superior, coito interrompido).

Inscritos na história das mulheres negras, o preconceito e a discriminação são obstáculos que devem ser superados ao longo da vida. A concepção vigente de negrura pode funcionar como um instrumento de opressão, que só pode ser superado com a constituição de uma personalidade que saiba lidar com esta realidade. Atinge as mulheres 
diferentemente, nas diferentes fases da vida. Hortência revela a percepção de uma dupla discriminação, por ser mulher e negra.

[O que você acha que é ser mulher negra?] Ai ai. Acho que não é muito diferente do que é ser mulher não. Só que tem esse pedaço que, além de tudo, quando a gente está crescendo que a gente percebe que a gente vai enfrentar o preconceito pela raça. Além dessas, outra discriminação por ser mulher, você vai sofrer a discriminação por ser negra também. Ao mesmo tempo que você resolve esta questão da discriminação na sua cabeça, acho que é a mesma coisa ( Hortênsia, mulher negra, ensino superior, laqueada).

Formulada uma concepção de negrura, alternativa àquela vigente, esta se definiria como uma capacidade de lidar com a realidade de discriminação, sem se submeter a ela; a história de vida das mulheres passa, assim, a ser diferente do predestinado. É, ao contrário, uma história de lutas por direitos e conquistas de dignidade, que fazem da mulher negra uma constante batalhadora no cotidiano. É tecendo, no dia-a-dia, a sua história de negritude, que se desenlaça um discurso afirmativo de vitórias.

Uma vitória, é uma vitória, eu me sinto muito feliz de ser mulher negra, mas uma batalha diária, Raquel, porque quem fala que não existe racismo nesse pais, ou desconhece a situação, ou não percebe, ou não quer ver. Assim porque isso não é verdade. E o racismo aqui eu não sei se é mascarado. Entendeu? Porque a partir do momento que a gente está ligado, você começa a perceber as várias situações. Eu vivo ligada, o tempo todo eu vivo em situação de ataque, o tempo todo. Então, o mais sutil pode demorar um pouquinho, eu percebo. Então, eu, assim, é uma vitória. Todos os dias a gente tem alguma batalha. Sabe! ? É mais que bom que a gente está lutando por isso, por mais dignidade, por mais respeito. Acho que tem ser assim 
mesmo. As pessoas têm que aprender a respeitar a gente (Luiza, mulher negra, ensino superior, camisinha masculina).

A liberdade de se despojar das marcas sócio-culturais, para construir uma identidade, capaz de fazer parte de um processo de transformação diária, coloca a mulher negra em confronto com as concepções de negrura vigentes. Desfeitos os equívocos, gerados pela difusão de idéias de negrura, mulheres negras podem desenvolver uma compreensão de si sem essencialismos, ou seja, sem uma compreensão naturalizada de ser negro, para viverem a si mesmas.

Olha, só penso nisso quando eu tenho um objetivo político. Isso, porque a gente tem o objetivo político de diminuir o preconceito. Então, tem situações que você me pergunta, tenho que me colocar, tenho que lembrar que é mulher negra, que não é parda, que não outra coisa. Entendeu? Mas fora disso, eu não estou com essa preocupação, se eu sou mulher negra, o tempo todo. Sou eu (Roberta, mulher negra, ensino superior, camisinha masculina).

\subsubsection{As mulheres brancas, por elas mesmas}

As mulheres brancas têm consciência de sua condição privilegiada, em função da cor. A brancura as favorece de tal forma, que as conquistas de gênero não são equivalentes às das mulheres negras. Existe uma barreira simbólica, que é pautada pela cor, e que não é facilmente superada pelas mulheres negras.

[Como você acha que é ser uma mulher branca hoje?] Eu acho que é mais fácil, a gente já conquistou mais coisa e, apesar do preconceito em cima da gente, é menor, porque a nossa cor de pele é igual à dos 
dominantes. 0 homem branco e a mulher branca. Acho que é mais fácil (Sara, mulher branca, ensino superior, tabelinha).

As dificuldades de uma dada condição de gênero constituem o maior problema para as mulheres brancas, que se colocam em outro patamar, diferente do da mulher negra, que teria, além do fato de ser mulher, o fato de ser negra, como obstáculo para obter respeito e atenção.

[E p'ra você o que é ser mulher branca no nosso meio?] Nesse contexto que a gente está falando, é um privilegio. Você sabe que você não vai sofrer o mesmo preconceito que uma mulher negra. Já sendo mulher, já sofre preconceito. Se eu tenho que levar minha filha no hospital, eu tenho que, antes de entrar, mudar de personalidade, falar grosso e falar alto. Lutar, porque senão eu vou ficar na fila de espera para ser atendida e tem que ser assim. Se fosse um homem, não. Não ia precisar. Já respeitam mais. Com uma mulher falando baixinho, ninguém dá importância, não atende direito. E é assim em qualquer lugar, em banco, no mercado, loja, no hospital. (Suzana, mulher branca, ensino superior, camisinha masculina).

Percebe-se que existe uma dada hierarquia, que constrói a desigualdade entre as mulheres. Essa hierarquia, de bases simbólicas, constitui o elemento-chave para a compreensão da diferença entre mulheres negras e brancas.

As visões, de negrura e de brancura, fazem parte de uma produção simbólica da diferença, no âmbito das relações de poder, que constroem o cotidiano e as vidas das pessoas. Sendo assim, não é possível deixar de lado a reflexão sobre as visões da diferença. 
6.3 Visões de mundo, acerca da diferença

A idéia da diferença demarcou o movimento feminista na década de 80. Segundo Darcy de OLIVEIRA (1999), esta idéia veio, nesse novo contexto, para destacar não a fragilidade das mulheres, ou inferioridade, mas para pluralizar os sujeitos sociais. Veio como uma reivindicação do direito à diferença. Com isso, as mulheres dão adeus à ambigüidade de outrora, quando reivindicavam a igualdade, simplesmente, colocando-se como capazes de desempenharem papéis iguais aos dos homens, incorrendo no risco de abandonarem o feminino. 0 feminismo mudou seu discurso com relação à questão, apostando no respeito à diferença.

Para SILVA (2000), identidade e diferença são partes de um processo de produção simbólica e discursiva e estão sujeitas às relações de poder. Nesse sentido, elas não são, também, somente definidas: são impostas, hierarquizadas e disputadas. A capacidade de definir identidade e de marcar a diferença não pode, segundo esse autor, ser separada das relações mais amplas de poder. Não sendo nunca isentas das relações de poder, identidade e diferença operam para incluir e excluir.

Nessa direção, afirmar a identidade significa demarcar fronteiras e fazer distinções. Nesse processo, é instaurada uma separação entre "nós" e "eles", que divide e classifica o mundo social. A divisão e a classificação são as bases para a hierarquização. Como nos referimos no capitulo anterior, segundo GIDDENS (1991), a modernidade eliminou as fronteiras e os riscos atribuídos ao "nós" e "eles". O que acontece é que os riscos são desigualmente distribuídos.

Ainda, segundo SILVA (2000), identidade e diferença estão estreitamente relacionadas à representação, que promove a existência e o sentido dado às identidades e às diferenças. De uma perspectiva pósestruturalista, a representação é, "como qualquer sistema de significação, uma forma de atribuição de sentido. Como tal, a representação é um sistema 
lingüístico e cultural: arbitrário, indeterminado e estreitamente ligado a relações de poder" (SILVA 2000:91).

A modernidade tardia, caracterizada por Antony Giddens, como marcada pela "diferença" e "atravessada por diferentes divisões e antagonismos sociais, que produzem uma variedade de diferentes "posições de sujeito, isto é, identidades para os indivíduos"(HALL 2001:17). É o campo em que o caráter das mudanças é constante.

Para HALL (2001:13), as identidades fazem parte de um "jogo de identidades". Segundo o autor, "O sujeito assume identidades diferentes em diferentes momentos, identidades que não são unificadas ao redor de um "eu" coerente. Dentro de nós, há identidades contraditórias, empurrando em diferentes direções, de tal modo que nossas identificações estão sendo continuamente deslocadas". A globalização produz o efeito "pluralizante" sobre as identidades, possibilitando uma variedade de novas posições de identificação, "tornando as identidades mais posicionais, mais políticas, mais plurais e diversas, menos fixas, unificadas e trans-históricas" (HALL 2001:87). 0 autor prossegue sua reflexão para caracterizar identidades, que oscilam entre a Tradição e a Tradução. 0 conceito de tradução descreve "aquelas formações de identidade que atravessam e intersectam as fronteiras naturais, compostas por pessoas que foram dispersadas, para sempre, de sua terra natal. Essas pessoas retêm fortes vínculos com seus lugares de origem e suas tradições, mas sem a ilusão de um retorno ao passado. Elas são obrigadas a negociar com as novas culturas em que vivem, sem simplesmente serem assimiladas por elas e sem perder completamente suas identidades. Elas carregam os traços das culturas das tradições, das linguagens e das histórias particulares, pelas quais foram marcadas. A diferença é que elas não são, e nunca serão, unificadas no velho sentido, porque elas são, irrevogavelmente, o produto de várias histórias e culturas interconectadas, pertencem a uma e, ao mesmo tempo, a várias "casas" (e não a uma "casa" particular). Pessoas pertencentes a essas culturas híbridas 
têm sido obrigadas a renunciarem ao sonho ou à ambição de redescobrir qualquer tipo de pureza cultural "perdida", ou de absolutismo étnico. Elas são, irrevogavelmente, traduzidas"(HALL 2001:88-89). Ora, este não é o processo pelo qual passaram as populações africanas, trazidas para o novo continente americano? Não foi o processo pelo qual a população negra passou no Brasil?

Embora, hegemonicamente, impere o "mito da democracia racial" (SCHWARCZ 1998), aparece, como exemplo revelador, de que não é difícil compreender o que é de fato uma discriminação, em nosso meio social, a idéia da existência de um tratamento diferenciado, entre negros e brancos.

A ideologia do "mito da democracia racial" se instalaria como uma recusa para pensar os conflitos, possivelmente, gerados pelas diferenças instituídas e para naturalizar tais diferenças, visando a isolar os indivíduos, impedindo a construção de uma idéia de negritude, como forma de resistência à conformidade social do que é "ser negro" no Brasil. Impossibilita a identificação "construída a partir do reconhecimento de uma origem comum, ou de características que são partilhadas com outros grupos ou pessoas, ou ainda a partir de um mesmo ideal" (HALL 2000:13)

Com base nessas concepções, podemos observar percepções que mulheres têm das diferenças, que estão contidas nelas e nos outros.

A percepção de que "mulheres" e "negros" são discriminados, perpassa todas as faixas de escolaridade e os dois segmentos de cor. 0 sentimento de que a diferença constrói relações, em nosso cotidiano, é comum a todas as mulheres. Não se trata, portanto, de uma temática alheia às realidades dessas mulheres, ao contrário, existe uma certa convivência com essa discussão e se trata de um assunto abordado no âmbito da família e de amigos; as informações, a respeito do tema, vêm de jornais, noticiários e revistas, depoimentos e entrevistas. Não podemos dizer que o grupo entrevistado esteja, de alguma forma, alienado do problema do racismo e 
das diferentes formas de discriminação que surgem na constituição de diferentes identidades e diferenças.

A principal "reclamação", quanto à discriminação, de "mulheres" brancas e negras, diz respeito ao mercado de trabalho. Neste campo, estariam as principais resistências para inserção ou comando das "mulheres" ou "negros", em geral, em algumas atividades.

O padrão estético e de beleza oprime, de diferentes formas, e existem experiências de discriminação ligadas ao fato de serem casadas. Por esta via, mulheres seriam excluídas de atividades de lazer com os colegas, após o trabalho. Outra forma de discriminação estaria ligada à liberdade sexual, homens teriam maior possibilidade de terem relações extraconjugais do que as mulheres.

É especialmente interessante para nossa pesquisa, a definição de discriminação, que aparece associada aos afetos. Mulheres discriminando mulheres, em função do status civil.

A percepção que nos passa uma das entrevistadas é a de que existiria uma hierarquia e, conseqüentemente, uma dada desigualdade entre mulheres solteiras, descasadas e casadas. Isto, de certa forma, estaria correlacionado à maior possibilidade de encontros sexuais, descompromissados, e a liberdade que têm as solteiras e que, de certa forma, estariam mais desprotegidas contra o HIV/Aids, do que as casadas. Ora, sabemos que a infecção pelo HIV/Aids está aumentando expressivamente entre mulheres casadas, de modo que tal percepção não corresponde à realidade .

Trata-se de uma fina forma de discriminação, em que há uma seleção minuciosa e lapidada do diferente, que o aproximaria do perigo, no caso, a contaminação. Está embutida, nesse discurso, a idéia de promiscuidade, como fonte de contágio e disseminação da doença. 
Esta forma de discriminação desvela o diferencialismo ao extremo, colocando abaixo a suposição de que existe uma dada igualdade na condição feminina, ao mesmo tempo em que revela um "jogo de identidades" (HALL 2001). Do mesmo modo que mulheres brancas seriam diferentes entre si, mulheres negras, também, seriam diferentes e viveriam a sua condição, em um processo de individuação, que as singulariza.

De acordo com PIERUCCI (2000), existe o diferencialismo de esquerda e o de direita. 0 primeiro apóia-se na "pluralidade cultural", para afirmar 0 direito à diferença, enquanto o segundo apóia-se na naturalização da diferença e baliza preconceitos e concepções, que justificam a desigualdade. 0 diferencialismo se opõe ao igualitarismo e, embora o direito à diferença de esquerda reafirme-se na necessidade de reconhecimento da pluralidade cultural, dá-se um "embroglio", à medida que o caminho teórico, pelo qual se dão essas reflexões, não se realizam no cotidiano; o que se encontra no cotidiano é um diferencialismo de direita.

A diferença, no entender de PIERUCCI (2000), é produtiva, produz singularidades e, apoiado em Louis Dumont, destaca que essa diferença coexiste com a hierarquização. Neste sentido, o depoimento da entrevistada, a seguir, aponta para as especificidades de diferentes condições conjugais, desvelando as complexas tramas nas quais é tecido o diferencialismo, e negada a igualdade. Nesse âmbito, é constituída a identidade conjugal, a partir do estado civil. SOUZAS (2000) verificou, entre mulheres de baixa renda, em São Paulo, que são diversos os caminhos pelos quais as mulheres assumem a identidade de mulheres casadas. Os rituais são vários e todos passam pelo corpo, como espaço de expressão dessa condição. No nosso exemplo abaixo, uma das mulheres destaca que a condição de mulher casada está relacionada a ter um único parceiro. Por serem adeptas da monogamia absoluta, estariam protegidas dos riscos de contaminação pelo HIV/Aids. A identidade masculina, no entanto, destaca-se por ser definida como tendo a liberdade de ter relações extraconjugais. Como assinala a 
entrevistada, isso é permitido aos homens, e não às mulheres. 0 que levaria a uma abertura para a contaminação pelo HIV/Aids. Por essa via, haveria uma entrega "cega" do destino das mulheres aos homens e uma ausência de autonomia das mulheres. Estamos diante de uma situação de dominação masculina, reinventada sobre outros ícones.

Eu percebo, por exemplo, uma discriminação muito grande entre mulheres com relação às casadas e às solteiras, entre as relações mantidas entre, por exemplo, as mulheres casadas, se têm uma relação extra conjugal, a amiga casada também, mesmo que ela tenha, mas se isso não é oficializado, ela condena a outra. Ela não faz a pergunta, por que é que essa outra está tendo, se é que ela tem que fazer essa tal pergunta. As mulheres solteiras, na mesma faixa de idade, por exemplo, na minha faixa de idade, vou falar da minha, eu percebo que existe um preconceito muito grande com relação à mulher solteira procurar vários parceiros; ela deveria se fixar num ou em nenhum, na verdade isso nem é deixado claro e uma hierarquia entre a mulher que casou e a mulher que não casou, a que casou teve sucesso e a que não casou não teve. Eu vejo muito isso. Porque eu fui dos dois grupos, eu fui a mulher solteira e hoje sou uma mulher casada e percebo isso. E tenho amigas que são casadas, amigas que são solteiras e amigas que são separadas, eu vejo muito a questão das relações. [Você acha que discriminam esses diferentes tipos de mulheres?] Discriminam, muito. E todos os três grupos são fechados: as casadas, as solteiras e as separadas. Discriminam, de maneiras diferentes, mas discriminam. Elas tolhem 0 comportamento dessas mulheres de maneira diferenciada que os homens nessas três mesmas classificações tem uma tolerância por parte da sociedade, por parte da própria mulher. 
[Você fala em relação aos relacionamento afetivos?] Aos relacionamentos afetivos. Focando bem os relacionamentos afetivos. O homem casado é visto como possível de ter uma relação extra-conjugal, por parte do homem e por parte da mulher [ $\mathrm{E}$ a mulher casada?] A mulher casada, tanto pela mulher, o que eu acho uma coisa meio complicada, por que é ela mesma se discrimina. Ela, a amiga dela, a família dela e o parceiro dela. Com o homem, uma parte discrimina, a outra não. Então nesse grupo todo, a família faz algum comentário, mas é uma coisa não com tanto peso, o amigo concorda, no caso da mulher, a amiga não concorda, só que para cada um, mudando o sexo é uma discriminação diferente. [E com relação às separadas e as solteiras?] É como se as separadas, por já terem sido casadas, oficialmente ou não, mas por já terem mantido um relacionamento, dividindo casa, ou seja, com a cara do casamento, a impressão que dá é que ela por que já teve, ela pode e com a solteira, o questionamento é, quantos você teve esse ano, ela não é feita diretamente assim, mas fica esse peso, de que quanto mais ela muda de parceiro, parece que deve se cuidar mais em relações às doenças que ela pode adquirir, parece que a mulher que se casou e separou ela não vai adquirir, ela está imune a isto. Com relação à promiscuidade, a ter tantos, com relação a ... é como se ela fosse culpada por não segurar um relacionamento [E essa cobrança você não percebe entre as descasadas?] Existe, mas não é tão grande. A mulher solteira, a mulher que ainda não se casou, tem um peso que é enorme, enorme. Eu sei, porque eu sofri este peso, eu ouço amigas sofrerem, falando de uma maneira que até o tom, o tom denota que não é só comentado pela amiga, por ela mesma, a maneira como ela reporta, há uma série de ressalvas nesse comentário. Hoje estou com esse, 
amanhã, estarei com outro, já estou vislumbrando um segundo caso, mas sempre com uma desculpa, [E com os homens, em relação aos homens solteiros e os descasados] Com relação a eles ou com relação a elas? [A ambos, não é?] Como é que eles se relacionam? O casado pode ter uma aventura fora, que é permitido, não é, e os solteiros e os descasados, será que eles estão à procura de um casamento, de uma relação, ou quanto mais, melhor? [Como é que você vê?] A impressão que eu tenho é que o homem solteiro, ele ... Ele tem o peso que a mulher solteira tem? [De que ainda não conseguiu conquistar uma mulher?] Eu acho que antigamente a questão era..., a questão era que quanto mais casos ele tinha, melhor ele era enquanto macho e, hoje em dia, a impressão que eu tenho é que ele está assumindo o papel que a mulher tinha antes, de procurar um relacionamento mais estável, é a impressão que dá, se isso é de fato, eu não sei. Às vezes, eu tenho a impressão que é apenas um texto, é como se ele invertesse a posição, só que, no entanto, eu sinto que, eu pouco consigo perceber do homem, porque ele pouco fala sobre 0 assunto. 0 homem não tem um histórico de comentar sobre os relacionamentos, o que ele pensa, com o amigo dele e não comenta com a amiga, comenta mais até com a amiga, mas mesmo assim ele é muito, ele resguarda muito essa questão, mesmo porque a amiga é o caso em potencial e com a mulher, 0 amigo não necessariamente é o caso em potencial. 0 homem ainda não perdeu essa questão do conquistar, o conquistar por conquistar, não ele mudou o discurso, então por isso ainda eu tenho grandes dúvidas, o discurso, ele é um discurso que tem a ver com o conteúdo ou é apenas só um discurso, por que a amiga ainda é potencialmente um caso. Não, eu ainda tenho grandes dúvidas com relação aos homens, eu não consigo 
penetrar muito nesse universo porque pouco falam sobre 0 assunto, mas o que eu percebo é que... [E o homem descasado, lá na frente, como é que ele está? Ele quer outro casamento, ele não quer mais... como é que você vê?] A gente tava falando em três grupos de mulheres e os correspondentes... Eu acho que o homem descasado ele tá com muito medo, com muito receio da mulher independente, porque independência, na cabeça do homem, a impressão que eu tenho, é a financeira, que era o que dividia antigamente essa independência, e hoje nós sabemos que não é isso, não é só ter o dinheiro, não é só ter o trabalho, porque muitas mulheres hoje têm essa condição, mas elas não têm essa liberdade, elas ainda continuam presas dentro dos seus casamentos, dentro das suas, do seu entendimento de mulher. Agora isso assustou o homem, porque, hoje, as mulheres, não é que hoje elas conseguem falar, porque elas conseguiam, elas tinham a capacidade de falar, mas hoje elas abrem espaço, elas quase que, quase que invadem o espaço, porque na verdade ele não é dado. O que acontece é que a mulher, hoje, fala certas coisas, que hoje o homem parece que ele tem que ser mais elaborado para um relacionamento. Com os homens solteiros, 0 que acontece, ele não vai p'ra um novo relacionamento como ia antes, pelo menos no início, eu não sei se ele ainda mantém essa mesma maneira, eu ainda tenho dúvidas em relação a isso, mas ele não vai como uma coisa possível, certa, mesmo porque, hoje em dia, não é tão certo assim, o homem hoje em dia tem encontrado muita dificuldade de se relacionar e a mulher, tem tido muito mais vontade de relacionamentos mais, mais, menos duradouros.Agora o homem, eu acho que ele tem tido mais receio, porque ele tá encontrando uma outra mulher. Esse mercado de homens e mulheres, nessa vida amorosa, ele 
mudou, bastante; nesse ponto, eu acho que a mulher, ela deu um grande passo, que foi admitir o seu, a sua sexualidade. Sair do papel da mulherzinha virgem e frágil e assumir que ela tem desejos sexuais sim, e isso assusta um pouco. Não sei se de fato assusta, se é apenas uma pró-forma, não sei, com relação ao homem de fato eu não sei te dizer (Joana, mulher branca, ensino médio, camisinha masculina).

As diferenciações constroem distinções de gênero e a discriminação vai por diferentes caminhos, percorrendo diferentes fases da vida da mulher, o que faz pensar que cada momento da vida de uma pessoa é único, em razões e sentidos, para a sua diferença.

O motivo que faz uma mulher, branca ou negra, ser discriminada, hoje, poderá não ser o mesmo de amanhã. Este quebra-cabeça, que se monta e remonta de diferentes formas, visa buscar novos sentidos e razões para re-hierarquização. Revelam-nos processos históricos e a constante transformação dos ícones que estigmatizam. Com isto, estamos afirmando que as categorias de gênero e raça não são estáticas, nem as identidades que as sustentam.

Segundo LOURO (1999), ao aceitarmos a construção de gênero como categoria histórica, estamos aceitando que há uma constante mudança na identidade de gênero e, por analogia, acrescentaríamos, também, de raça.

Mulheres, e por que não, também, homens, que não vivem as feminilidades e masculinidades hegemônicas, fazem críticas às concepções binárias, que opõem homens e mulheres. Este processo, a que já se referiu SCOTT (1991), explode as categorias fixas e dicotômicas, para multiplicar e flexibilizar tais categorias. A "fragmentação" tem um impacto no "jogo das 
identidades", que pode ser manipulado no jogo do poder (HALL 2001). Nesse sentido, é que é interessante, quando a interlocutora Joana aponta para as diferentes fases da vida da mulher, como passíveis de estigmatização, revelando que os ícones são móveis e passíveis de transformação.

Quanto mais idade a mulher tiver, dou um exemplo, passou dos 30 anos, se ela não se resolveu financeiramente, esse termo "se resolveu" é um termo que eu ouço muito, o termo não é bem esse, mas eu estou usando porque ele vai exatamente no ponto, a questão: ela não tem o carro dela, profissionalmente ela ainda não está... ela ainda não está definida dentro do mercado de trabalho, ela não tem a casa dela, de maneira que ela possa carregar esse relacionamento, que seja ou que não seja duradouro, ela tem pouco p'ra barganhar dentro desse mercado, porque ela já tem idade, então melhor uma mocinha, porque já que eu vou me relacionar, eu ouço muito isso dos homens, por isso que,às vezes, eu tenho grandes receios em relação a essa nova postura do homem, de procurar relacionamentos mais duradouros, porque em contrapartida isso vai contrário a essa postura, a mulher com mais idade, ela tem mais dificuldade com relacionamento, ela tem que apresentar uma conta bancária melhor, parece que a mulher de hoje está assumindo relacionamentos nas suas despesas, parece que ela, eu não sei em que medida é isso, eu não sei o quanto isso é grande, mas eu percebo muito isso e eu não via isso antes. Quando eu entrei nesse mundo de assumir o meu desejo sexual, ter a minha primeira transa, isso não existia e faz pouco tempo, faz 20 anos isso. Eu percebo que hoje é muito freqüente isso, é muito comentado, muito claramente entre as mulheres e em público, como uma..., como uma vantagem: Ah, eu já estou bem resolvida ou eu não estou, como uma desvantagem, parece que ela está bancando coisas que, quem bancava antes era 0 homem, então nesse ponto há essa discriminação, sim. Tem a 
discriminação do grupo em que ela convive ou pela etnia dela ou pela condição econômica dela, pela condição sócio-econômica tem a discriminação muito clara. (Joana, mulher branca, ensino médio, camisinha masculina).

Como foi mencionado, anteriormente, os ícones que estigmatizam, nem sempre são os mesmos, e a discriminação da "mulher", e particularmente, da "negra", é historicamente demarcada, a partir da exclusão. A diferença se coloca aí como um elemento constitutivo das relações sociais e de identidades. Mulheres negras, como menciona GONZÁLES (1982), sofre a tripla discriminação (de gênero, raça e classe). A norma da "boa aparência", o preconceito enraizado nas relações raciais, ao mesmo tempo em que se publiciza o mito da democracia racial, faz da mulher negra um objeto óbvio de exclusão sócio-econômica, tendo na sua história de vida percepções que demarcam essas dificuldades. Como pudemos observar nos ítens relativos à liberdade e à maternidade, há uma vivência diferenciada de mulheres negras e brancas. A liberdade, limitada à conjugalidade, uma vivência possibilitada só recentemente para mulheres negras, pois, como apontam GONZÁLES (1982:99) e PINTO, BOULOS e ASSIS (2000), há um ditado preconceituoso, que diz " preta pr'a cozinhar/mulata pr'a fornicar/ e branca pr'a casar", revelando que a mulher negra não é pensada, historicamente, como companheira, esposa e mãe. Esse ditado foi recolhido do adágio popular por FREIRE (2003). Conforme GONZÁLES (1982), no Brasil, dentro do ideário da "democracia racial", a figura da "Mãe preta", originada na atuação da mucama, teve uma função fundamental na estrutura psíquica de quem quer que seja, e representou, ao lado do "Pai João", o negro acomodado e que aceitou, passivamente, a escravidão. Essas figuras ideológicas depositam na mulher negra uma dada alienação dos processos sócio-históricos. Pensamos que essas figuras persistem em nosso ideário, através de concepções que procuram se 
acomodar ao contexto e reiteram idéias, como a da maternidade, como dom. Desse modo, um ranço do período higienista persiste no discurso de mulheres negras e mostram que elas vivem um status diferenciado em relação às brancas, como se estivessem em um degrau abaixo, que ainda não problematizaram alguns campos da sua vida, como por exemplo, a experiência da maternidade, e que a questão racial determina uma experiência de vida não comparável à da mulher branca. Como ressalta SAFFIOTI (1992), são as diferenças, e não as semelhanças, que constroem o poder. Nesse sentido, a diferença de cor se instala no cotidiano para ratificar as injustiças sociais e moldar percepções. No caso das mulheres negras, a tripla discriminação é claramente colocada para impedir o acesso a um status social igualitário, que se verifica na própria concepção construída sobre a liberdade e a maternidade. Como apontam as entrevistadas Regina e Roberta, as pessoas seguem um "programinha", um script e, neste, o negro tem um papel inferiorizado.

Eu acho que fazem, ainda tem aquela coisa da boa aparência, ainda, quando você vai selecionar alguém, como se fosse um programinha, se você vai olhar as coisas da aparência, se não é branco, não tem boa aparência, não é bonito, a não ser que você seja a "gostosona", tipo Naomi Campbel. Mas também não vai servir para qualquer emprego. A não ser para passarela, sei se dá para entender, ainda tem uma coisa assim (Regina, mulher negra, ensino superior, camisinha masculina).

Essa minha amiga professora, ela entrou no banheiro para se arrumar e a servente falou: "Você está no banheiro de professores, o seu é do outro lado". Esta foi uma situação dessas. E ela já é uma professora já... muito boa professora.... todo mundo que conhece sabe. Então, essa situação É mulher, é negra, então pensam: é impossível ser professora. Na cabeça 
das pessoas (Roberta, mulher negra, ensino superior, camisinha masculina).

Mulheres negras e brancas vivem determinados campos da vida, como a maternidade, a liberdade e a própria condição de gênero, de forma também distinta. Isto, em certa medida, está referido à posição estrutural das mulheres negras e brancas na sociedade brasileira. 0 racismo, presente nas relações sociais brasileiras, apresenta a pobreza como explicação e não o preconceito racial, escamoteando o racismo, à moda brasileira. Mas o que dizer quando comparamos mulheres negras, de escolaridade superior, com as brancas, também, de nível superior? Quando perguntamos sobre a liberdade, como vimos, enquanto mulheres negras pensam na possibilidade de viver a conjugalidade, de forma compartilhada, mulheres brancas pensam em conquistar novos espaços e postos na vida pública. É também interessante reter a concepção de maternidade como dom, que mulheres negras carregam como um resquício de uma ideologia higienista. Neste aspecto, percebe-se que ser mulher negra é estar enraizada no tradicionalismo, do qual faz parte o mito da democracia racial. Ao mesmo tempo, especialmente no discurso de mulheres de escolaridade superior, percebe-se um movimento de mudança em direção a uma visão das relações de gênero mais igualitárias. Mulheres brancas, especialmente as de escolaridade superior, já constatam, no seu cotidiano, maior autonomia. 


\section{CARACTERIZANDO PRÁTICAS SOCIAIS HOMOGÊNEAS E DIFERENCIADAS}

EM RELAÇÃO À PREVENÇÃO DA GRAVIDEZ E DO HIV/AIDS, NA INTERSECÇÃO CONJUGALIDADE, RELAÇÕES DE GÊNERO E RAÇA

\section{1 Uso de métodos contraceptivos}

Muito embora não possamos realizar uma descrição dos dois grupos de mulheres entrevistadas, para fins de inferência e generalização, no que diz respeito ao uso de método contraceptivo, os dados empíricos coletados apresentam, em termos comparativos, aspectos interessantes de caracterização do grupo entrevistado. Isso pode ser observado quando, a partir da literatura especializada, podemos tecer um panorama geral de investigação sobre o tema e utilizar os dados da presente pesquisa, como casos exemplares.

Baseada em dados da PNDS (Pesquisa Nacional sobre Demografia e Saúde) dos anos de 1996 e 1986, VIEIRA (2003) afirma que houve um considerável aumento no uso de contraceptivos, entre mulheres unidas, de 15 a 44 anos de idade. A proporção de uso para essa faixa etária era de $65,8 \%$, em 1986, contra 76,7\% em 1996. Essa proporção ultrapassa a média dos países desenvolvidos, que é de $72 \%$. Há, no entanto, segundo a autora, uma diferença significativa, pois, enquanto em países desenvolvidos há uma prevalência de métodos reversíveis, no Brasil observa-se um aumento progressivo da esterilização feminina. Além do fato de a esterilização, nos paises desenvolvidos, ser mais equilibrada, em termos proporcionais, para homens e mulheres. Assinala ainda VIEIRA (2003), apoiada em Berquó (1999), que, enquanto mulheres analfabetas tendiam a utilizar o coito interrompido, as de maior escolaridade preferiam métodos comportamentais, como a tabela, que exige um maior conhecimento do corpo.

As taxas de esterilização feminina, segundo VIEIRA (2003), cresceram menos em São Paulo do que em regiões do Norte, Nordeste e Centro Oeste. E ainda, o aumento das esterilizações, no Brasil, veio 
acompanhado de um decréscimo da idade ao se esterilizar, que em 1986 era de 31,4 e, em 1996, passou a ser 29,9 anos. Apoiada em Perpétuo (1996), afirma, também, que as mulheres que estão se esterilizando moram nas áreas mais pobres do país, rurais, e apresentam baixa escolaridade.

Prosseguindo em sua análise, VIEIRA (2003) refere a predominância, em 1996, de dois métodos contraceptivos: a esterilização cirúrgica $(52,2 \%)$ e a pílula $(26,9 \%)$, enquanto outros métodos representariam $21 \%$. Ou seja, a maioria opta pela esterilização cirúrgica, sugerindo medicalização excessiva do corpo feminino. Segundo a autora, o maior acesso a métodos reversíveis se dá no setor privado de saúde, sendo que as usuárias de pílula, em sua maioria, obtêm este método no balcão de farmácia e sem acompanhamento médico adequado. Há também uma informação qualitativamente inadequada sobre contraceptivos. Configura-se um cenário marcado pela medicalização e privatização do acesso a contraceptivos.

Diante desse quadro, percebemos que a escolha de um dado método contraceptivo ainda é realizada, por parte das mulheres brasileiras, em geral, de maneira "não consciente" . Recentemente normatizada, a esterilização voluntária tornou-se o centro da discussão sobre Direitos Reprodutivos no Brasil, na década de 90. Como aponta BERQUÓ (2002), em reflexão sobre a esterilização voluntária com a atual legislação, a demanda por este recurso cirúrgico é maior do que o número daquelas realizadas. Isto, ao nosso ver, significa que se trata de uma prática altamente difundida e pouco refletida pelas mulheres. De acordo com HITA (s/d), ao se analisarem os fatores de arrependimento pela esterilização voluntária, defronta-se com um contexto, no qual mulheres vêem, na esterilização, uma saída para a situação de desregulação da vida reprodutiva e promessa de liberdade sexual com a cirurgia. 
As altas taxas de laqueaduras tubárias refletem, também, a conquista do acesso a uma tecnologia no campo reprodutivo e revelam a busca por práticas sexuais desvinculadas da reprodução, uma tendência moderna. É interessante observar que outros métodos reversíveis, também eficazes, não apresentam a mesma demanda. É uma busca pela adaptação aos modernos padrões de fecundidade no Brasil que, no século XX, teve uma forte queda, graças às esterilizações (CAMARANO, ARAUJ O, CARNEIRO, 1999).

É certo que, uma vez grávidas, mulheres, em especial as negras e pobres, enfrentam inúmeros obstáculos e custos demasiados, além do risco de vida, para efetuar um aborto. Isso as coloca numa situação pouco confortável e perversa.

Lizandro Nei GUALBERTO (2003) e Elza BERQUÓ (2002) apontam para duas realidades, importantes para a nossa discussão. GUALBERTO (2003) demonstra, mediante leitura dos dados da Pesquisa Nacional de Demografia e Saúde (PNDS 1996), o comportamento contraceptivo por raça/cor no Brasil e, nesse quadro, mulheres negras têm mais chances de se esterilizarem do que de adotarem um método tradicional ou feminino. Esse tipo de constatação se reflete em nossa pesquisa. Agrega-se a isto a questão de quem são as mulheres que estão se submetendo à esterilização. $\mathrm{Na}$ DECLARAÇÃO DE ITAPECERICA DA SERRA (1993), documento do movimento de mulheres negras, já anteriormente analisado, havia a denúncia da problemática escolha pela esterilização voluntária a que mulheres negras se submetiam. Assim, ao lado da desvantagem estrutural que a população negra enfrenta no país, ou é resultado dela, a esterilização contribui para aumentar sua vulnerabilidade ao HIV/Aids, como aponta LOPES (2003). Essa autora defende a tese de que a situação estrutural tem, no sintoma do racismo, um agravo à situação das mulheres com HIV/Aids. Desse modo, ficaevidente a desvantagem social para mulheres negras. Essa desigualdade se expressa na pauperização mais acentuada e na piora da qualidade de vida 
desse segmento, que contribuem para essa desvantagem e maior vulnerabilidade. BERQUÓ (2002) problematiza a questão da esterilização voluntária, mostrando-a como uma possibilidade diversa para homens e mulheres. Os homens têm a sua demanda atendida mais rapidamente do que as mulheres, em função da demanda das mulheres ser maior. Essa maior demanda é explicada por BERQUÓ (1994) pela "cultura da esterilização", que atinge mulheres brancas e negras, indistintamente.

No entanto, a literatura sobre a questão da esterilização cirúrgica mostra, ainda, pontos polêmicos como, por exemplo, a questão do arrependimento entre mulheres esterilizadas. Segundo HITA (s/d), a noção de arrependimento se apresentou como pouco familiar no estudo que empreendeu entre mulheres das camadas populares de Salvador. Essa noção fica obscurecida por questões emergentes, que dizem respeito à sobrevivência e a problemas sociais, como a violência. É por isso que não consideramos a questão da esterilização totalmente esclarecida, em nosso contexto. 0 quadro, abaixo, apresenta o número de mulheres entrevistadas, por método contraceptivo, e serve como ilustração desses pontos polêmicos. 
Quadro 3 - Métodos que estavam sendo utilizados pelas mulheres entrevistadas, segundo cor e níveis de escolaridade, São Paulo, 2003

\begin{tabular}{|c|c|c|}
\hline ESCOLARIDADE & NEGRAS & BRANCAS \\
\hline SUPERIOR & $\begin{array}{l}\text { (4) Camisinha mascul. } \\
\text { (1) Laqueadura } \\
\text { (1) Coito interrompido }\end{array}$ & $\begin{array}{l}\text { (3) Camisinha mascul. } \\
\text { (1) Vasectomia } \\
\text { (1) DIU } \\
\text { (1) Tabela }\end{array}$ \\
\hline MÉDIO & $\begin{array}{l}\text { (2) Laqueadura } \\
\text { (1) Anticoncepcional } \\
\text { injetável } \\
\text { (1) Não estava usando } \\
\text { nenhum método } \\
\text { (1) Histerectomizada } \\
\text { (1) Estava grávida }\end{array}$ & $\begin{array}{l}\text { (2) Camisinha mascul. } \\
\text { (3) Vasectomia } \\
\text { (1) Não estava usando } \\
\text { nenhum método }\end{array}$ \\
\hline FUNDAMENTAL & $\begin{array}{l}\text { (1) Camisinha }+ \\
\text { Laqueadura } \\
\text { (3) Laqueadura } \\
\text { (1) Pílula } \\
\text { (1) Extraiu as trompas }\end{array}$ & $\begin{array}{l}\text { (1) camisinha } \\
\text { (1) camisinha e coito } \\
\text { interrompido } \\
\text { (1) Laqueadura } \\
\text { (1) Vasectomia } \\
\text { (1) Não estava usando } \\
\text { nenhum método } \\
\text { (1) Tem dificuldade de } \\
\text { engravidar }\end{array}$ \\
\hline
\end{tabular}


Embora mulheres brancas entrevistadas tenham expressado, tanto como as negras, o conhecimento da existência de vários métodos, na prática, o que se observa é a concentração em alguns poucos métodos, a exemplo do que ocorre com a população brasileira. Fato a destacar é a diferença observada nos tipos de métodos adotados por mulheres brancas e negras. Em relação às primeiras, a "opção", em sua maioria, foi por métodos de controle masculino, como a camisinha masculina e a vasectomia, o que parece revelar que as mulheres brancas entrevistadas seguem um padrão, em que os homens são mais chamados à responsabilidade da contracepção, enquanto as mulheres negras, de escolaridade média e fundamental entrevistadas seguiriam um padrão de uso "massificado" de métodos. Isso, na medida em que mencionaram o uso da laqueadura e o anticoncepcional que, segundo literatura especializada (GUALBERTO 2003), ocupam os primeiros lugares, observando-se mudança deste padrão entre as mulheres negras de nível superior, em que a camisinha passa a ser mais mencionada. GUALBERTO (2003:70), que procurou avaliar a importância da variável raça/cor no comportamento reprodutivo das mulheres brasileiras, encontrou o seguinte resultado: "Das cinco modalidades enfocadas (métodos femininos, camisinha, métodos coitais tradicionais, esterilização e não uso), as negras apresentaram menores chances de passagem de não uso de métodos para[uso] de qualquer outro método, e foram também as que apresentaram maiores chances (entenda-se, odds maiores que 1 ) de adoção de esterilização vis-à-vis métodos tradicionais ou métodos femininos.". Esses resultados colocam a questão da esterilização e mulheres negras sob foco. Reforçam, ainda, a atenção sobre esta questão episódios como o relatado por PINTO (2002). Segundo a autora, um representante do poder público municipal de São Paulo buscou legislar para a gratuidade da esterilização nos casos de a mulher ser negra ou parda. De acordo com o representante público, essas mulheres não teriam assimilado, ainda, os novos padrões de comportamento reprodutivo, aumentando seus índices de natalidade. 
Medidas como esta reacendem a discussão sobre o racismo institucional, com vistas ao controle demográfico.

Ainda que não possamos fazer inferências, vale mencionar que, no caso dos dados de caracterização do grupo pesquisado, a vasectomia foi mencionada como um recurso preferido pelos casais, sendo as mulheres, no caso, todas brancas. 0 fato de a vasectomia não ter aparecido entre as mulheres negras entrevistadas, pode sugerir indagações, passíveis de novas investigações na área, dentre elas, se mulheres negras assumiriam muito mais a responsabilidade pela contracepção, ao contrário de mulheres brancas. É interessante observar que as mulheres negras entrevistadas, de escolaridade média e fundamental, diferenciam-se das de escolaridade superior, em função das primeiras preferirem a laqueadura $e$, as de escolaridade superior, a camisinha. Na fala, a seguir, podemos observar uma das formas típicas de se "justificar" a opção pela laqueadura, estreitamente relacionada a questões de gênero.

[E, em comparação, assim, com outros métodos de... anticoncepcional ? Você acha que é melhor?]. Ah, eu acho porque... podia até que se fazer a vasectomia, não é? Mas como tem muito machão nesse mundo, a vasectomia não é (risos)... Eu acho que muito mais simples; trinta minutos, 0 homem ta andando na boa, não é? A mulher já é mais difícil. Mas..eu acho que...quando a mulher... ela não pode mesmo, sabe? Ela não pode ter com esse, não pode ter com outro, eu acho que o melhor é fazer mesmo. Assim fica sossegada, não é? Então... pra mim, eu achei uma boa opção, mesmo porque 0 [nome do marido] não queria fazer laqueadura (risos), não a... a vasectomia... Não queria fazer. Falei "Então, ta. Então eu vou fazer. "Já tá cortando ali mesmo, já faz no parto. Aí eu fiz e estou sossegada (Maria Célia, mulher negra, ensino médio, laqueadura). 
No grupo entrevistado podemos observar, também, uma distinção entre mulheres negras e brancas, de qualquer nível de escolaridade. Enquanto as negras, em sua maioria, se distinguem em dois grupos, as que preferem, por um lado, a camisinha e, por outro, a laqueadura, as mulheres brancas apresentam métodos diversificados, sendo que a preferência por métodos de controle masculino se destaca. Algumas mulheres brancas, dos vários grupos de escolaridade, diferem das negras por estarem unidas a homens vasectomizados. As mulheres laqueadas, nesta pesquisa, são, predominantemente, negras, com escolaridade média e fundamental, apontando que este grupo segue mais a tendência observada por GUALBERTO (2003), que caracteriza as mulheres negras, de menor autonomia, como aquelas que, quando decidem pela contracepção, têm maiores chances de optar pela esterilização.

As mulheres de nossa pesquisa, ao não mencionarem o uso do condom como método preferencial estão, ao que parecem, mais vulneráveis ao HIV/Aids, notadamente aquelas de níveis de escolaridades média e fundamental. Com exceção de uma mulher negra de ensino fundamental e uma mulher branca de ensino superior, as demais entrevistadas previnem-se apenas da gravidez indesejada.

Problema, assim, afetivo eu tive um problema com ele uma vez, mas foi por causa de uma quase traição. Aí eu perdi a metade da confiança. Quer dizer, não ficou confirmada a traição. Entendeu? Mas eu fiquei com dúvida, e quando eu fico com dúvida de alguma coisa, melhor que eu veja logo ou então fica na cabeça e não sai. Então, algumas coisas, alguns cuidados depois disso que comecei a tomar, por exemplo, a gente só transa de camisinha. [Vocês dois só transam de camisinha?] Se não eu não confio (Eliane, mulher negra, ensino fundamental, laqueadura associada à camisinha). 
[Vamos falar então um pouquinho nos métodos anticoncepcionais. Você usa camisinha?] Sempre. [E o que você acha do uso da camisinha?] Não só como contraceptivo, mas também como uma forma de prevenção contra as doenças. Eu acho qualquer contraceptivo, ou meu ou dele, meio chato. Porque ainda não criaram a forma ideal de liberdade $e$ anticonceptivo. A não ser que você tire o útero. Eu acho que todos ainda são, não tem uma formatação final boa. [Hã, hã.] A camisinha, eu me dou bem com ela, não chego a ter problema, não acho que é uma maravilha ... [Você só usa a camisinha] Só camisinha. [Confia?] Confio. Eu uso e não engravido há 10 anos e quando engravidei foi porque não usei, literalmente eu não usei camisinha (Solimar, mulher branca, ensino superior, camisinha masculina).

O exercício livre da sexualidade é inibido por dificuldades para o controle da fecundidade, que se reverte na esterilização voluntária, e colocam mulheres em situação de alternativas reprodutivas escassas (CARVALHO 2001). O ideal é que houvesse orientação para a prática do sexo seguro, como aponta BARBOSA (1997), mas isso, na maioria dos casos, não acontece e, se considerarmos a assertiva de GUALBERTO (2003) de que, quanto maior a autonomia da mulher, maior a probabilidade de ela escolher um método que preserve a sua saúde sexual e reprodutiva, poderíamos deduzir que mulheres negras, e de menor escolaridade, estariam, ao que parece, entre aquelas que teriam maiores chances de escolher a laqueadura tubária, refletindo a perversidade de sua condição.

Segundo FANON (1983: 18), "Um homem que possui a linguagem, possui, também, o mundo que esta linguagem abrange e que, através dela, se exprime". Com base neste pressuposto, as mulheres brancas, ao lado das 
negras de escolaridade superior, estariam mais preparadas do que aquelas de escolaridade fundamental, à realidade atual, que inclui como desafio, dentre muitos outros, o enfrentamento da epidemia da Aids.

\section{2 Aborto}

De acordo com ROCHA e ANDALAF NETO (2003:293), de cada 100 gestações, 26 resultariam em aborto no mundo e, no Brasil, esta razão seria de 23 em cada 100 gestações, ou seja, $23 \%$ das gestações terminariam em aborto não legal no Brasil, por ano. Segundo os autores, "abortamentos esses que são realizados paralelamente a uma lei, que incrimina as mulheres e que representam um grave problema de saúde pública".

No conjunto de mulheres entrevistadas, tanto o aborto mencionado como espontâneo, como o provocado, ocorrem em uma proporção importante em relação aos nascidos vivos. 0 aborto assumidamente provocado encontra-se entre as mulheres de nível superior. 0 maior número de abortos, no grupo de mulheres negras, está na escolaridade média, com sete abortos referidos como espontâneos e um, provocado. Enquanto, entre as mulheres brancas, o maior número de abortos ocorre no estrato de escolaridade superior, com cinco provocados e um espontâneo. Se considerarmos que a menção ao aborto é um dado muito difícil de ser obtido em pesquisas empíricas, deveremos reconhecer, no entanto, sua importância no campo da saúde reprodutiva, pelas diferentes ordens de questões que encerra. A despeito desses limites, vale registrar que é somente nos grupos de mulheres brancas e negras, com maior nível de escolaridade, que a maior menção ao aborto provocado aparece, no caso de nossa investigação. 0 que não ocorre, em relação aos demais níveis de escolaridade, em que as mulheres, na sua maioria, quando mencionaram a existência do aborto, a ele se referiram como espontâneo. À medida que não seja possível cotejar esses dados com a literatura, porque não disponível nesse nível de detalhe, 
consideramos interessante que investigações empíricas, com amostras representativas, sejam levadas a cabo, tendo em vista diferenciar a ocorrência, não somente de tipos de aborto, mas considerar sua distribuição, por raça e condição social.

Quadro 4 - Mulheres negras, de diferentes níveis de escolaridade, número de filhos e de abortos

\begin{tabular}{|l|l|l|}
\hline \multicolumn{1}{|c|}{$\begin{array}{l}\text { NOME } \\
\text { FANTASIA }\end{array}$} & $\begin{array}{l}\text { No } \\
\text { FILHOS }\end{array}$ & $\begin{array}{l}\text { ABORTOS } \\
\text { (P)ROVOCADO } \\
\text { (E)SPONTÂNE } \\
\text { O }\end{array}$ \\
\hline ENSINO SUPERIOR \\
\hline Roberta & 2 & 0 \\
\hline Regina & 0 & $1(\mathrm{P})$ \\
\hline Marta & 0 & $1(\mathrm{P})$ \\
\hline Luisa & 0 & 0 \\
\hline Luci & 0 & $1(\mathrm{P})$ \\
\hline Hortênsia & 4 & $1(\mathrm{P})$ \\
\hline Ensino Médio & \multicolumn{2}{|l|}{} \\
\hline Ana & 3 & 0 \\
\hline Amanda & 1 & $1(\mathrm{P})$ e3(E) \\
\hline Marina & 1 & $1(\mathrm{E})$ \\
\hline Vânia & 1 & 0 \\
\hline Maria Célia & 2 & $2(\mathrm{E})$ \\
\hline Maria Wilma & 2 & $1(\mathrm{E})$ \\
\hline Ensino Fundamental & \multicolumn{1}{|l|}{} \\
\hline Pámela & 2 & $1(\mathrm{E})$ \\
\hline Rosana & 3 & 0 \\
\hline Dalila & 2 & 0 \\
\hline Eliane & 3 & 0 \\
\hline Sabrina & 3 & $1(\mathrm{E})$ \\
\hline Regiane & 3 & 0 \\
\hline \multicolumn{5}{|l|}{} \\
\hline
\end{tabular}


Quadro 5 - Mulheres Brancas, de diferentes níveis de escolaridade, segundo número de filhos e de abortos

\begin{tabular}{|l|l|l|}
\hline $\begin{array}{l}\text { NOME } \\
\text { FANTASIA }\end{array}$ & $\begin{array}{l}\text { No DE } \\
\text { FILHOS }\end{array}$ & $\begin{array}{l}\text { ABORTOS } \\
\text { (P)ROVOCADO } \\
\text { (E)ESPONTÂNEO }\end{array}$ \\
\hline \multicolumn{2}{|l|}{ Ensino Superior } \\
\hline Sonia & 1 & $1(\mathrm{P})$ \\
\hline Solimar & 0 & $1(\mathrm{E})$ e 1(P) \\
\hline Suzana & 2 & 0 \\
\hline Sara & 3 & 0 \\
\hline Juçara & 0 & 0 \\
\hline Suzete & 1 & $3(\mathrm{P})$ \\
\hline Ensino Médio & \multicolumn{2}{|l|}{} \\
\hline Carla & 2 & 0 \\
\hline Teresa & 2 & 0 \\
\hline Amália & 1 & 0 \\
\hline Joana & 0 & $2(\mathrm{P})$ e $1(\mathrm{E})$ \\
\hline Gilmara & 1 & 0 \\
\hline Cris & 2 & 0 \\
\hline Ensino Fundamental & \multicolumn{2}{|l|}{} \\
\hline Gorete & 4 & \multicolumn{2}{|l|}{} \\
\hline Lucia & 3 & 0 \\
\hline Denise & 2 & $1(\mathrm{E})$ \\
\hline Rosa & 2 & 0 \\
\hline Mary & 1 & 0 \\
\hline NP & 2 & 0 \\
\hline
\end{tabular}


Sobre os motivos que levam as mulheres ao aborto provocado, seus dilemas, defesa dos direitos à escolha, assim como à assistência dos serviços de saúde, dentre outros, os discursos das mulheres muito revelam.

0 aborto provocado nem sempre acontece em condições adequadas, tendo complicações de inúmeras ordens, tanto físicas como psicológicas. Trata-se de um recurso caro, que muitas vezes onera as mulheres que não contam com a participação dos parceiros. No depoimento, a seguir, a entrevistada descreve seu percurso até o aborto, destacando-se a culpa implícita.

Fiz abortos [E como foram esses abortos p'ra você? Você provocou.?] Não tive a participação dos parceiros, é...[Como que foi, foi numa clínica?] Foi numa clínica, é muito caro, eu não tinha o dinheiro, fui com uma amiga, eu não tive o apoio familiar. [Você chegou a contar p'ra os seus parceiros que estava grávida?] Contei, [E aí?] Os parceiros, na verdade, era o mesmo parceiro, em momentos diferentes.Ele, da $1 \underline{\underline{a}}$ vez, ele simplesmente não apareceu. Não vi mais [Ele concordou com a idéia do aborto, de fazer? ] Ele não, ele simplesmente ouviu o que eu havia dito, não se manifestou. [Ouviu que você estava grávida e foi embora?] Foi embora. Voltou depois, reatamos com muita dificuldade, depois quis o filho, fiquei ate 3 meses e meio, mas ele desapareceu e eu não tinha trabalho na época, tinha que tirar [E a segunda gravidez foi da mesma pessoa?] Da mesma pessoa [Você contou e ele disse o que? Ele queria o filho?] Queria muito o filho e aí ele foi embora pro Sul e eu fiquei sabendo que já tava de 3 meses e meio e eu fiz um aborto de risco [Também em clínica?] Também em clínica. Você sabe quais foram os métodos utilizados? Sucção [Você foi sozinha fazer o aborto ou você foi com alguém?] Fui com uma amiga [Sua família também não soube?] Tentei contar, mas 
recebi um recado muito direto da minha mãe que disse, eu não cheguei a dizer o que era, eu ia começar a dizer e o recado que eu recebi foi: você é uma moça que teve toda a liberdade e admiro em você a sua responsabilidade com seus atos.A conversa terminou assim, com a voz da minha mãe dizendo isto. [Aí você foi procurar sozinha...?] Aí eu fui procurar sozinha que a tentativa da conversa não terminou bem. [Isso da 2 a vez?] Da $1^{\underline{a}}$ e da $2^{a}$ vez, mas aí eu percebi que não teria, tínhamos um certo problema em casa, assim com meu pai. [Você não teria apoio?] Teria apoio sim, da minha mãe, minha mãe não me apoiava por causa do meu pai, ela tinha medo, porque se eu engravidasse, existia uma ameaça de morte para a minha mãe. A coisa era muito complicada, e eu sei disso, porque meu pai sempre disse isso muito claramente para a família. Então, eu entendi o que a minha mãe queria dizer e fiquei quieta. Me lembro que eu voltei para casa no dia, como se nada tivesse acontecido, só que sangrando. Porque você termina, sai da clínica, mas você ainda está muito mal, o certo seria você dormir e no outro dia sair de lá, mas você sai, praticamente sangrando. E você não paga pouco, paga muito, principalmente no 20 aborto, um aborto de risco. [Você se sentiu segura?] Fisicamente? Não, muito medo, muita insegurança, não conhecia o lugar, sempre indicado por alguém, de alguém, de alguém, sempre muito, ainda mais naquela época era muito problemático ainda, não sei como é hoje (Joana, mulher branca, ensino médio, camisinha masculina).

O aborto provocado leva a mulher a ter dilemas e sentimentos controversos sobre a questão, ao mesmo tempo em que ela não quer ter 0 
filho, sente-se culpada pelo aborto. O homem, nem sempre, participa do processo junto à mulher e não é responsabilizado socialmente. Mulheres negras estão na base da pirâmide social de distribuição de renda e poder. Analisando a questão do aborto, com recorte racial étnico, PINTO (2002) observou que, quando a mulher é negra, ela é muito mais pressionada pelo parceiro a fazer aborto.

Mulheres negras e brancas têm uma avaliação, nem sempre positiva, quanto ao direito ao aborto, dada a realidade vivida por algumas mulheres. Também há aquelas que, por motivos religiosos ou morais, são contra. É um debate, quase sempre, polêmico e cheio de controvérsias.

[E o que... o que você acha do aborto? Você acha que... deve ser permitido?.] Ah, não. Aborto, não. Porque, quem faz... eu acho que quem... é... faz um aborto, tá tirando uma vida de uma, de um ser humano, que é... já... uma pessoa que tá grávida, já tem um ser na barriga, então, se abortar, tá... tá matando uma pessoa. Então, p'ra mim, isso aí é crime. Eu não... eu sou contra (Dalila, mulher negra, ensino fundamental).

Existe muito jeito de você evitar uma gravidez. Antigamente, era difícil. Agora, é tudo tão fácil. Você vai no posto, você tem o anticoncepcional injetável. Você pode tomar mensalmente. Você interromper uma vida assim, eu sou contra. Também não tenho nada contra quem faz (Mary, mulher branca, ensino fundamental, marido vasectomizado).

Mesmo considerando que se trata de um direito garantido por lei, em algumas situações, existem aquelas que são contra 0 aborto.

Ah, porque a criança não tem culpa, não é? Mesmo no caso de estupro, que diz que é legalizado, não é? Mas eu também não 
concordo, não. Não concordo. É porque já tem vida, não é?... a partir do momento que tá grávida, já tem vida. Então, não concordo por isso (Suzana, mulher negra, ensino fundamental, laqueada).

0 discurso, com relação à criminalização do aborto, não difere por escolaridade, existem mulheres contra e a favor, nos diferentes segmentos de escolaridade. Embora não seja o mais comum, certas opiniões são baseadas em crenças e conceitos religiosos. No seguimento, abaixo, a interlocutora revela caminhos pelos quais se podem construir os argumentos típicos contra o aborto.

Quando eu era solteira, eu não sabia, não tinha pensado na história. Não tinha pensado. Ouvia falar e por uma questão religiosa. Depois que eu fui mãe, que eu fui ver o meu nenê mexendo na minha barriga que eu entendi o quê que era. Eu já sabia o quê que era, mas a coisa não tinha entrado aqui. Inclusive eu tenho uma culpa comigo que eu carrego até hoje, eu peço todos os dias que eu tenha a chance de reverter isso. Eu fui responsável pela morte de um bebê. Porque eu namorava um rapaz, tinha um amigo nosso que pediu dinheiro emprestado para fazer um aborto. Eu movimentava a conta desse meu namorado "transfere tanto para a conta de tal pessoa para isso, para isso". Eu não tenho nada com isso, eu estou num banco, eu tenho que transferir o dinheiro. Hoje, eu não faria isso jamais, eu sujei minha mão. Fiz a transferência. [Hoje em dia o aborto é permitido, quando a gravidez parte de um estupro ou quando há risco de vida para o bebê ou para a mãe? 0 que você acha da lei?] Mesmo assim, eu sou 
contra. [Mesmo em caso de estupro e em caso de risco de vida?] Em caso de estupro, a mãe não teve culpa e 0 bebê, menos ainda, então se alguém tem que pagar não será o bebê. Porque o bebê que não pode se defender. $\mathrm{E}$ vai ser uma criança que vem ao mundo e vai ser maltratada, sem condições de ser criada, mas ninguém tem o direito de tirar uma vida. Vou matar o meu filho. Então é cometer um erro em cima do outro. Aconteceu foi um estupro. Agora, eu não posso errar em cima. Eu sou contra, é uma fatalidade, a criança vai sofrer por isso, vai ser rejeitada, vai sofrer, mas eu não posso matá-la por causa disso. Eu vou matar todos os mendigos por causa disso. É a mesma coisa. No caso de risco contra a mãe. Mesmo que não fosse, existem mulheres que morrem de parto e nem por isso se mata a criança. Existem pessoas que morrem todos os dias, a toda hora, por diversos motivos. Esse é apenas um deles. Eu não vou matar uma criança para salvar a mãe. Eu deixaria correr livremente. [Mesmo que nascesse com problema?] Mesmo que nascesse com problema, acho que não se pode botar a mão numa coisa dessas. 0 homem não tem direito de botar a mão numa coisa dessas. É desrespeito à vida. Não tem direito, direito ele não tem ( Suzana, mulher branca, ensino superior, camisinha masculina).

Embora não seja a maioria do grupo entrevistado, existem aquelas que vêem o aborto como um direito de escolha individual, ao qual as mulheres deveriam ter acesso. 
[E como você vê as leis de aborto? Sabe que hoje o aborto só é permitido no Brasil nos casos de estupro, não é, ou nos casos em que a mãe ou o bebê sofrem problemas que comprometam a vida deles.] Um absurdo [ Por que você vê a lei dessa forma?] Eu acho que é uma limitação grande, eu acho que gera aí, as pessoas passarem pelo aborto de uma maneira clandestina, de uma maneira sem cuidados médicos, profissional, correndo risco de vida. Eu acho deplorável, eu acho que realmente 0 aborto, as pessoas deveriam ter 0 direito de escolher e arcar com essa escolha e com a responsabilidade emocional, espiritual, ser livre nessa escolha, não é ter essa possibilidade, eu acho que o ser humano poderia ter esse direito (Sonia, mulher branca, ensino superior, marido vasectomizado).

O aborto é uma questão que se coloca em termos de crenças e valores e suplanta a questão da informação e nível de escolaridade. 0 que entra em debate é a forma de controle da fecundidade, que deve ser realmente eficaz. Não encontramos diferenças, em nível de discurso, com relação ao aborto, e a polêmica em torno do mesmo alcança, igualmente, mulheres negras e brancas. Assim, observamos mulheres de nível superior e de estratos médio e fundamental de escolaridade se colocarem, por vezes, contra, e, por vezes, a favor do aborto. E algumas são contra, mesmo nos casos em que o aborto é legalizado, como no caso de estupro ou risco de vida da mulher. 0 que os discursos apontam é para uma certa alienação das mulheres entrevistadas, com relação aos direitos sexuais e reprodutivos.

A gravidez indesejada é uma questão que permeia o discurso das mulheres. 0 aborto é, antes de tudo, o avesso de uma ideologia que entronizou a mulher-mãe como a "rainha do lar". Nesse processo, a 
maternidade, ovacionada, foi alvo da medicalização e do controle, no interior de um processo de higienização da família e do lar. 0 corpo feminino, nesse contexto, foi sendo gradativamente medicalizado e transformado em objeto de tecnologia médica. As parteiras, inicialmente as cuidadoras preferenciais no partejar, foram sendo gradativamente excluídas da cena do parto, o qual foi transformado em ato médico (PEREIRA 2000; VIEIRA 2002).

0 aborto constitui a negação de toda uma ideologia, que alimenta a culpa e a crença na maternidade, como destino único às mulheres e, através de um processo de higienização, exerce o controle sobre o corpo feminino. Como referiu RAGO (1987), a ideologia da higienização devolveu a mulher ao lar, disciplinando suas atividades como mulher e mãe. Nesse sentido, o aborto é um ato de negação de um poder instituído. Entretanto, clandestinamente executado, pode trazer graves perigos para a saúde da mulher, que corre riscos de vida.

0 aborto é legalmente permitido apenas em situações de risco de vida para a grávida, e em caso de estupro. A penalidade para as mulheres que se submetem ao aborto, de forma ilegal, varia de um a 10 anos de prisão, com pena duplicada para aqueles que praticam ou auxiliam. Entretanto, a realidade do aborto, no Brasil, revela um outro quadro: mulheres praticam-no de diferentes formas (FONSECA et. al 1996), e de acordo com a sua condição de classe.

O aborto é uma das principais causas de morte materna (PINTO e SOUZAS 2002) e, segundo SCAVONE e CÔRTES (2000), a legalização de sua prática, mesmo nos casos de estupro e de risco para a mulher grávida, enfrenta inúmeros obstáculos sociais, morais e políticos. Os tabus em torno da prática do aborto são inúmeros e a questão da religiosidade acrescenta maiores obstáculos para a prática. Ainda segundo SCAVONE e CÔRTES (2000), mesmo mulheres que passaram por situações de aborto provocado podem tornar-se contra a prática, em função da forma pela qual ele é 
praticado no Brasil, clandestinamente, e em péssimas condições, principalmente entre mulheres das camadas populares.

Um dos principais obstáculos para enfrentamento da questão do aborto é o debate jurídico-político acerca da questão (ROCHA e ANDALAFT NETO 2003). Para CORREA e ÁVILA (2003), as normas jurídicas, que criminalizam o aborto, ocultam a desigualdade que há entre os sexos, no domínio da sexualidade, e a falta de autonomia das mulheres que engravidam contra sua própria vontade. Outro aspecto obscurecido pela discussão ideológica sobre o aborto, segundo as mesmas autoras, é a dificuldade, por parte das mulheres, de negociação em relação à sexualidade e de arcar, psicológica e finaceiramente, com os custos da reprodução. 0 direito de decidir sobre sua fecundidade, segundo CORREA e ÁVILA (2003), é um direito humano.

Associado a isso, as dificuldades de implementação do PAISM (Programa de Assistência Integral à Saúde da Mulher) e mais, especificamente, a ausência de planejamento familiar (OSIS 1998) corroboram para o agravamento da situação. 
8. IDENTIFICANDO DILEMAS E CONTRADIÇÕES NAS PRÁTICAS CONTRACEPTIVAS E NA PREVENÇÃO DO HIV/AIDS, SOB A ÓTICA DAS RELAÇÕES DE GÊNERO E DE RAÇA

\section{1 Laqueadura: uma medida radical}

Os usos da camisinha e da laqueadura se diferenciam, por serem dois métodos que demarcam estilos de vida diversos e desvelam uma relação com o corpo, também diferenciada. Ao que parece, dentre as entrevistadas, aquelas que optaram pela laqueadura prefeririam não mais ficarem grávidas. As mulheres entrevistadas, que preferem a camisinha, não aceitariam uma intervenção no seu corpo para fins da contracepção. A razão da escolha pela vasectomia, neste sentido, assemelha-se àquelas que optaram pela camisinha: trata-se de uma medida de controle, no qual o homem é chamado à responsabilidade no trato da anticoncepção.

A laqueadura e a camisinha diferem, por serem dois métodos que respondem diferentemente às necessidades das mulheres. Embora as usuárias de ambos os métodos queiram evitar uma gravidez indesejada, a forma pela qual elas obtêm isso é distinta. A laqueadura, considerada um método mais radical por sua irreversibilidade, é preferida por mulheres que negociam menos com seus parceiros e já têm o número de filhos desejado, enquanto a camisinha é um método mais flexível e exige muito mais a negociação entre os pares (BARBOSA 1997). Existe, também, a disseminada "cultura da esterilização" que, segundo BERQUÓ (1994), é responsável pelas altas taxas de esterilização. Mulheres que são esterilizadas recomendam à suas amigas, ou parentes, e têm, no seu médico, um parceiro para esta empreitada. 0 recurso à esterilização vai ao encontro da necessidade de controle da fecundidade, em condições em que não haja o desejo de ter mais filhos e exista a dificuldade de diálogo com os parceiros, na busca de um outro método. 
A esterilização, entre nós, é uma resposta à demanda das mulheres por métodos contraceptivos, uma perversa combinação entre a falha de políticas públicas e "distorções de mercado" (CORRÊA e ÁVILA 2003). Segundo as autoras, em 1996, a esterilização era "ligeiramente mais alta entre mulheres negras, no caso de São Paulo, no Centro-Leste, no Norte e Centro-Oeste"(CORREA e ÁVILA 2003:46).

CARVALHO (2001) avaliou a trajetória de mulheres até chegarem à esterilização feminina e evidenciou a busca das mulheres por um controle efetivo da fecundidade, que outros métodos utilizados não promoveram. Segundo CORRÊA e ÁVILA (2003), há uma preferência pela esterilização, entre mulheres das áreas urbanas e menos escolarizadas. A escolha pela esterilização, segundo as autoras, abrange aspectos positivos, como a maior liberdade sexual, e negativos, como 0 arrependimento, relatado por algumas mulheres que se esterilizaram muito jovens, e quando há mudança de parceiro. Além disso, somam-se razões financeiras e de saúde, insatisfações com outros métodos e falta de colaboração dos parceiros na contracepção

Observamos que existe, veiculado nos discursos das mulheres entrevistadas, uma percepção de que mulheres pobres não podem ter "muitos" filhos e que a laqueadura seria o melhor método indicado nesses casos. Existe, ao que parece, uma postura "controlista," por parte de algumas mulheres. É interessante notar que, justamente as mulheres que expressaram isso claramente, tiveram seus maridos vasectomizados, postura evidenciada em uma prática contraceptiva.

[E a laqueadura, o que você acha da laqueadura?][....] Eu acho que se isso ficasse disponível p'ra as camadas sociais menos favorecidas, eu acho que ajudaria muito, eu acho que ajudaria até a diminuir um pouco o índice de pobreza do nosso país. Hoje você pára, por exemplo, num farol e você vê uma mãe com um bebê no colo e cinco filhos pedindo moedinhas, e ela grávida; eu acho que essa situação é 
uma situação bastante triste e que a saúde, que a saúde pública poderia ajudar, mas também não ajuda, não tem recurso p'ra ajudar essa pessoa. Com todo o direito de escolha, mas orientando e direcionando (Sonia, mulher branca, ensino superior, marido vasectomizado).

Eu acho que a questão tem que ser no poder aquisitivo da pessoa. Eu acho que a mulher que já tem 4 filhos, o marido ganha o salário mínimo, ela não trabalha, ela engravidou novamente... também que já sou a favor de cortar a trompa dessa mulher p'ra ela nunca mais ter filho na vida. Eu acho que devia ter uma lei no Brasil assim, famílias de baixa renda, que não conseguem sustentar mais que 2 filhos, na segunda gestação, já esteriliza (Amália, mulher branca, ensino médio, marido vasectomizado).

As mulheres laqueadas, que participaram deste estudo, na sua maioria, negras - somente uma é branca -, encontram-se satisfeitas com a escolha de seu método, por Ihes trazer maior segurança com relação à prevenção de uma gravidez. Trata-se da busca de uma estabilidade, proporcionada somente por um método radical, como a laqueadura. Traz, também, o mesmo tipo de idéia, citado anteriormente como "controlista", ao mesmo tempo em que, também, revela a maior liberdade sexual permitida pela esterilização.

[E o que você acha da laqueadura? Você já fez, não é?] Maravilhosa. Ai que bom. Você faz sexo a hora que quer; como quer; sem medo... [Pega doença.] Pega nada, porque se cuida. P'ra poder... Eu acho bom. Assim... bom assim: porque você se previ[...], você... você... é uma coisa que você... assim: tem muitas mulheres aí que fica tendo fi[...]... é melhor porque você... você vai ficar tendo filho aí p'ra tá deixando sofrer, p'ra deixar passar fome, essas coisa. É p'ra... é p'ra 
você evitar. Se você não se dá com remédio, se você não... 0 companheiro não quer usar camisinha... se você não pode usar esses método que tem p'ra evitar, então a laqueadura é uma forma de você, entendeu?, parar de ter um monte de filho.Tem mulher que tem dez, antigamente tinha dez, quinze filho. Já pensou você ter de[...], cinco, seis filho hoje? Dois, três, já tá difícil, imagine... entendeu? Por isso, acho bom por essa parte. Não é por causa de sexo, essas coisas (estou falando isso aí p'ras menina ficar doida); mas por essa parte. Porque... é difícil, não é?, você... vai ficar fazendo filho aí pro mundo. Não tem condições. É por causa disso; é uma forma de se prevenir de ter um monte de filho aí e deixar (Sabrina, mulher negra, ensino fundamental, laqueada).

Mulheres negras e brancas, quando insatisfeitas com o uso do seu método, recorrem à esterilização feminina. Investigando o discurso, é possível encontrar falas reveladoras de que a esterilização feminina suscita dilemas e controvérsias e razões para a sua recusa, enquanto recurso contraceptivo, assim como, para a sua aceitação. No seguimento, abaixo, apresentamos uma mulher que aceita a laqueadura como método

Fiz. Faz dezenove anos que já fiz. Eu acho...melhor, porque as vezes, a pessoa tem três, quatro filho... precisa ver se a pessoa tem condições de ter mais filho, não é?... se a pessoa quer ou não, tudo... foi... eu... fiquei... p'ra mim foi bom, não é? (Regiane, mulher negra, ensino fundamental, laqueada).

A necessidade de negociação com o parceiro, de um método contraceptivo (SOUZAS 2000), apresenta-se como obstáculo para a adoção 
de um, que não seja definitivo, como é o caso da camisinha, como aponta a interlocutora:

Ah, eu acho que só serve no meu caso assim, que eu não podia pensar na hipótese de ficar grávida de novo. Mas eu acho que se as pessoas usassem camisinhas corretamente e se fosse uma coisa mais acordada entre os parceiros, você nem precisaria usar esse método de intervenção (Hortênsia, mulher negra, ensino superior, laqueada).

A decisão pela esterilização é marcada por uma certa ambigüidade, e a regulação supera a desregulação absoluta, situação que prevalecia antes de a lei $9.263 / 96$ ser promulgada (CORREA e ÁVILA 2003). Uma certa cumplicidade entre médico e paciente pode ser observada no discurso de mulheres:

Ah porque eu perguntei pra ela [a mãe], porque eu não podia tomar o remédio, e o preservativo me dava alergia. Ela falou pra mim fazer dessa maneira. E assim eu sempre fiz. Eu ficava na faixa de três anos. Você pode ver meus filhos é tudo de 3 em três anos. Aí, optei pela lavagem, e a laqueadura, eu nem sabia, o médico fez, e quando eu acordei, ele falou que tinha feito.[Eles nem te consultaram?] Assim, quando eu estava fazendo o pré - natal ele me perguntava se eu queria fazer. Eu falei: se fosse realmente necessário, aí eu faria. Ele falou "Você teria condições de pagar?" eu falei: "Não". Porque nas quatro gravidezes, em nenhuma das gravidezes, meu marido estava trabalhando.. Eu não teria condições mesmo de fazer. "E se você fosse obrigada a fazer, você faria?" "Faria" por causa disso que ele me operou.[Mas ele não chegou a te consultar?] Só assim, durante o pré-natal que a gente conversava (Gorete, mulher branca, ensino fundamental, laqueada). 
Percebe-se que um certo discurso ideológico corrobora para a manutenção de altas taxas de esterilização. A tal "cultura da esterilização" (BERQUÓ 1994) se estabelece junto a um caldo de cultura que difunde idéias "controlistas", que se traduziriam em uma ideologia que divulga uma idéia equivocada de que há um crescimento populacional excessivo, em função de mulheres pobres terem muitos filhos. Segundo ROLAND (1995), há, no caso da população negra, que coincide com a população mais pobre, um decréscimo na taxa de crescimento populacional, que só se explica pelo abuso nas esterilizações.

8. 2 A recusa à laqueadura e a saída pela vasectomia

Seja se laqueando, ou tendo o marido vasectomizado, algumas mulheres, negras e brancas, são portadoras de um discurso radical com relação à contracepção. A vasectomia, nesse contexto, é apresentada como uma alternativa menos prejudicial, para ambos os lados. 0 homem, nesse caso, teria que assumir a responsabilidade pela contracepção.

Ah, eu não gosto não, acho que é sacanagem. A mulher sofre p'ra caramba p'ra ter o filho, depois vai fazer laqueadura, vai sofrer mais um tanto, sabe. [...], eu acho que não é legal, tudo bem, igual minha mãe fez, ela teve que fazer uma cesárea, só p'ra fazer a laqueadura e que demorou horas, ela nunca teve nada, a gente, e as mulheres que tem problemas por causa da laqueadura, então eu acho que é meio, é muito agressivo com meu corpo, eu acho que a mulher já tem uma constituição delicada, pode vir a aparecerem problemas referentes a isso. Então, eu acho que porque a mulher tem que fazer isso, a mulher tem que tomar comprimido, sendo que você sabe que não evita doença, a mulher que vai fazer a laqueadura, sendo que 0 
homem pode fazer a vasectomia, que não dura cinco minutos, entendeu, é rápido, toma um pontinho ali, enquanto a mulher tem que se detonar toda, p'ra que? Acho meio, acho mal isso aí (Carla, mulher branca, ensino médio, marido vasectomizado).

Por um lado, nem sempre isso é possível, e a laqueadura, apesar de mais racional, no sentido de que mulheres, muitas vezes, têm uma ultima gravidez, antes de fazer a laqueadura, quando este não for o caso, trata-se de mais uma cirurgia somente para a laqueadura. Por outro lado, existe a dificuldade dos serviços de saúde sexual e reprodutiva que, nem sempre, estão preparados para atenderem os homens. Como referem MARCHI el al. (2003), no campo da saúde sexual e reprodutiva, os avanços não têm sido compatíveis com a necessidade. Observando casais e opção pela vasectomia, MARCHI et al. (2003) constataram que os casais já chegavam ao serviço, decididos pela vasectomia, influenciados por amigos, colegas, vizinhos, parentes. É interessante que o mesmo processo ocorre com as mulheres que optam pela laqueadura. Este fato redundava em uma maior dificuldade para o programa de orientação no aconselhamento. Isto também foi verificado em outros serviços de planejamento familiar. As pessoas, segundo MARCHI et al (2003), constroem suas representações sobre os métodos, valendo-se de diversas fontes, corretas ou não, e com base nessa representação fazem sua escolha. É um desafio para os serviços de aconselhamento, no campo da saúde sexual e reprodutiva, abordarem com sucesso e oferecerem uma oportunidade para refletirem acerca da sua escolha reprodutiva.

8. 3 Uso da camisinha

A centralidade da responsabilidade da contracepção sobre as mulheres revela, entre outras coisas, o quanto ainda convivemos com um alto grau de desigualdade social e de gênero, particularmente em relação ao cotidiano das mulheres. Os dados da nossa realidade contribuem para 
colocar a população brasileira na contramão dos processos de transformação e de democratização das relações sociais e, conseqüentemente, das relações de gênero, fundamentais para se pensarem as possibilidades de implantação de uma política de Saúde Reprodutiva, condizente com os preceitos da conferência de Beijing (1995), em uma ampliação do PAISM.

Tratando da questão, SIMÕES BARBOSA (1995) demonstra como a negociação da mulher para 0 uso do preservativo acha-se dependente do diálogo com o parceiro e, ao mesmo tempo, está recoberta, pela dificuldade de homens e mulheres tratarem esse assunto. A questão parece estar relacionada, em parte, às dificuldades das mulheres em avaliarem, junto ao seu parceiro, os riscos de contrairem doenças sexualmente transmissíveis, incluindo HIV/AIDS, assim como a opção pelo melhor método de contracepção, que envolve decisões sobre o número de filhos e momento de engravidar, ou não, entre outras.

A propósito da questão da negociação sexual, como estratégia para a prevenção das DSTs/AIDS, BARBOSA (1997) identifica, em narrativas de homens e mulheres entrevistados, permanências e mudanças de valores sociais. Segundo a autora, as transformações sociais vividas nos últimos anos reordenaram o jogo de forças das relações de gênero. Tanto homens, quanto mulheres, concordam sobre isso e associam essa nova situação a um exercício mais prazeroso da sexualidade.

A relação entre homens e mulheres continua, no entanto, sendo demarcada pelas diferenças de gênero, mantendo presente a desigualdade, sendo, sobretudo, no terreno da sexualidade que se expressam as ambigüidades e contradições das recentes conquistas femininas. A ampliação do poder e autonomia feminina perante os homens permitiu um discurso mais igualitário e a elaboração de um projeto de vida a dois, baseado na confiança e na possibilidade de existência de transparência nas relações, inclusive na sexual. No entanto, BARBOSA (1997) observa, em sua pesquisa, 
que tal fato não implicou, entretanto, discussão e introdução do preservativo, em termos preventivos, entre aquelas pessoas casadas, ou vivendo um relacionamento consolidado.

Constata, ainda, a autora, que o significado do uso do preservativo é diferenciado, segundo estado conjugal. Para mulheres solteiras e separadas, o uso insinua-se como forma de exercício da sua autonomia, ao passo que, para casadas ou envolvidas em relacionamentos consolidados, o mesmo não acontece. 0 desafio, segundo essa mesma autora, é incorporar no campo da saúde reprodutiva, notadamente na prevenção do HIV/AIDS, os homens nas ações estratégicas de intervenção, dentro de uma perspectiva transformadora.

A idéia positiva de negociação sexual aparece, no contexto das discussões sobre AIDS e Saúde Reprodutiva, como estratégia para a implementação e uso de métodos de barreira (diafragma e o preservativo) e para a diminuição da vulnerabilidade feminina. Tentativas, com a finalidade de compreender quais os fatores (negativos e positivos) relacionados à capacidade de a mulher negociar, junto ao parceiro, maior proteção quanto às DSTS/AIDS, gravidez indesejada, entre outras coisas, permitiriam, por conseguinte, na leitura de BARBOSA (1997), elaborar estratégias visando à ampliação do poder de negociação das mulheres. Citando Petchesky (in press), a autora apresenta a necessidade de apreender a questão da negociação, como um processo socialmente construído, dentro do qual se dão decisões reprodutivas. Essas, por sua vez, estão condicionadas, em certa medida, à realidade partilhada pelos indivíduos. As disputas pelo poder e controle nas relações interpessoais assumem um caráter lúdico, contrapondo-se às idéias de opressão e vitimização das mulheres.

Nesse sentido, é importante distinguir liberdade e coerção no processo de decisão, sendo que a decisão, em questão, não deve ser considerada como um caso isolado. Torna-se necessário debruçar-se sobre 
os sistemas de valores e normas que estruturam as relações de gênero, que vão modelar e dar significado às práticas e decisões tomadas por homens e mulheres. Gênero, como categoria analítica, pretende distinguir práticas sexuais de papéis sexuais atribuídos às mulheres e aos homens e se instala na discussão como uma maneira de indicar as construções sociais sobre os papéis, ditos próprios aos homens e às mulheres.

No argumento de SCOTT (1991), os conceitos de poder, nem sempre, referem-se diretamente ao gênero em si mesmo, ainda que reforcem distinções de gênero. É uma categoria imposta ao corpo sexuado, no seguinte sentido: destaca o sistema de relações que pode incluir o sexo, mas não é determinado pelo sexo, nem determina diretamente a sexualidade.

De acordo com SCOTT (1991: 17), gênero é uma primeira instância, um primeiro campo, no interior do qual o poder é articulado, e não o único. Citando Bourdieu, a autora coloca que "Estabelecido um conjunto objetivo de referências, o conceito de gênero estrutura a percepção e a organização concreta e simbólica de toda vida social. À medida que essas referências passam a estabelecer distribuições de poder (um controle ou um acesso diferencial aos recursos materiais e simbólicos), o gênero torna-se implicado na concepção e na construção do poder em si" .

No âmbito das discussões de gênero, as escolhas, decisões e arranjos reprodutivos dos indivíduos partem ou resultam em processos de negociação e decisão, não só condicionados, em certa medida, pela realidade partilhada por outros indivíduos, como também são modelados por ações regidas, segundo um conjunto de valores e normas sociais, imbuídas de um certo dinamismo e possibilidade de transformação, rearranjos e resignificação que, ao mesmo tempo, mimetizam a lógica pela qual se estabelece o poder na sociedade. 
Entre nossas entrevistadas, muito embora haja pontos de vista positivos, o uso da camisinha é excluído, na maioria dos casos, como método de prevenção do HIV/Aids, e pouco negociado, como método de prevenção da gravidez. Isso significa que a camisinha não é usada em todas as relações sexuais. É utilizada, por vezes, associada à tabelinha no período fértil, quando há maior risco de gravidez, na maioria dos casos.

A negociação da camisinha torna-se ainda mais difícil nos casos em que a mulher é laqueada, ou o marido é vasectomizado. Como exemplo, apontamos o caso de uma mulher, cujo marido é vasectomizado, por ela referir diretamente a questão da possível recusa do parceiro em aceitar o uso da camisinha.

Não por que a gente tem essa história da vasectomia, ele fez vasectomia e se eu pedir p'ra ele usar camisinha, ele vai falar: "por que, você está transando com outro?" Você entendeu? Então não tem porque, entre nós dois não tem porque. Agora, se ele, é o que falo p'ra ele, se ele for fazer com outra pessoa, tem que usar (Amália, mulher branca, ensino médio, marido vasectomizado).

Existem mulheres que não gostam também da camisinha, não se trata somente de homens não gostarem e da dificuldade de negociação, mas de uma resistência, também, feminina, com relação ao uso do preservativo, além do dispositivo da confiança no parceiro funcionar como válvula de escape à prevenção das DST'S/Aids. Verificamos esse comportamento resistente ao uso do preservativo entre mulheres de baixa renda. Revelou-se ainda que mulheres recorrem ao dispositivo da confiança, para a exclusão da camisinha como método.

[Vocês usam camisinha?] Não [Por que vocês não usam?] Eu não gosto. Não desconfio dele. Não, porque se eu desconfiar, 
não precisa usar camisinha porque eu não terei relação com ele. Não terei mesmo. Mas hoje eu não desconfio dele. [Por que vocês não usam?] Eu não gosto. Não desconfio dele. (Gorete, mulher branca, ensino fundamental, laqueada).

Mulheres Negras e Brancas, usuárias da camisinha

As usuárias de camisinha, em sua maioria, optaram por esse método para prevenção da gravidez, porém, por vezes, ela aparece associada à prevenção de doenças sexualmente transmissíveis. A consciência dos riscos de infecção ao HIV/Aids reforçam o uso do preservativo.

[O que você acha do uso da camisinha hoje em dia?] Ah, maravilhoso. Maravilhoso. Eu sempre usei, desde a primeira relação, e foram muito poucas as relações que eu tive, sem 0 uso da camisinha. Algumas situações em que eu estava usando pílula e mais... depois eu abandonei. Eu nunca tomei pílula mais que dois meses, três meses e depois voltava para a camisinha (J uçara, mulher branca, ensino superior, camisinha masculina).

[E como que você vê a camisinha?] Para mim, a principio, a camisinha era só um anticoncepcional, que foi criado com conceitos de moral e religião. Só que não é mais assim, agora é prevenção para outras doenças e que, p'ra mim, o modelo que eu tenho de casamento é aquele que se diz que a gente não pode confiar em ninguém, tem que usar com o próprio marido, porque existe uma porcentagem muito grande de mulheres que foram infectadas pelo HIV pelo próprio marido. Então, nesse sentido, é uma maravilhosa impressão (Suzana, mulher branca, ensino superior, camisinha masculina ). 
O uso da camisinha é indicado para a situação de transição, quando não se sabe da condição sorológica do parceiro, depois pode haver a negociação e associação com a tabelinha, por exemplo. Esta flexibilidade do método, a não contra-indicação e facilidade no acesso, faz da camisinha um método preferido por algumas mulheres negras, de nível superior.

Acho que é um método que eu considero mais light, mais prático, não tem efeitos físicos por um lado, por outro lado por causa da proteção de outras doenças sexualmente transmissíveis. É relativamente barato. Eu acho, eu não sei hoje em dia quanto custa uma cartela de anticoncepcional.. Mas se você tiver um relacionamento legal com o parceiro, tiver certos acordos firmados, se não precisa usar o tempo todo, se pode usar só no período fértil. Lá em casa a gente fez assim. A gente sempre usava, aí, nós dois fizemos o teste, aí, como deu negativo, a gente optou assim, fora período fértil a gente até transa sem, mas isso é bem negociado (Regina, mulher negra, ensino superior, camisinha masculina).

Mulheres Negras e Brancas e a recusa à camisinha

Entre as mulheres entrevistadas para esta pesquisa, a confiança também se quebra na emergência de casos de infidelidade do parceiro, e a experiência da traição faz com que mulheres pesem a possibilidade de contaminação. Mas, assumir o uso da camisinha significa, em nível do imaginário social, assumir que o marido tem outra mulher. Isto, para algumas mulheres negras e brancas, significa a dissolução do pacto conjugal. Foi semelhante a constatação de SOUZAS (2000), em sua pesquisa. É por conta disso que mulheres preferem incorrer no risco de contaminação, a solicitar ao parceiro que use camisinha: 
[0 que você acha do uso da camisinha?] Eu nunca usei. Eu não sei. Acho que é bom, não é ? Acho que é bom todo mundo se prevenir. Uns tempos ai atrás eu pedi para ele usar. Aí, ele não quis usar. Então eu num... fiquei um bom tempo sem ter relação com ele, eu fazia ele gozar, somente ele, e eu não. Então quer dizer. Ele falava p'ra mim "Você não confia mais em mim" E papapapa. "Num estou saindo com mais ninguém" $E$ isso e aquilo. Então, entre aspas, eu estou arriscando. Eu estou errada. Mas eu estou num risco, que eu não poderia estar, eu tenho consciência disso (Denise, mulher branca, ensino fundamental, não usa nenhum método).

Não, eu tenho medo assim, porque... como que eu... eu desconfio e eu tenho quase certeza que eu to... to... tenho... to sendo traída, eu não sei qual é a... a compa[...], a parce[...], a parceira com quem ele tá andando, vai que essa parce[...], pessoa tem alguma doença e me contamina. Então na... na... na minha opinião, no meu caso, eu, eu, eu tenho, teria que usar cami[...], tinha que usar camisinha... p'ra me prevenir... [...] comigo, não é? (Dalila, mulher negra, ensino fundamental, usuária de pílula, ficará 5 meses sem usar a pílula).

A camisinha é postergada e indicada para fora do casamento, para as relações esporádicas. Esta informação soma-se ao discurso da confiança no parceiro. A lógica presente nessas idéias é dicotômica e separa, de forma re-hierarquizada, "mulheres-da-rua" e "mulheres-da-casa". Dessa forma, pode-se pensar que as mulheres, cujos parceiros usam camisinha, podem ser situadas, por este discurso, no lugar da "mulher-da-rua", o que pode significar a dissolução de acordos conjugais. Passando pela distinção e definição entre espaços público e privado na sociedade brasileira, SARTI 
(1996), apoiando parte de sua análise em Da MATTA (1990), reflete sobre a rua/casa como domínios sociais dicotômicos e mutuamente excludentes, que presidem uma certa lógica organizativa da sociedade brasileira. A partir dessa lógica, o âmbito do privado, a casa, apresenta-se como o lugar em que as relações sociais são orquestradas "naturalmente" pelas hierarquias do sexo e das idades, em que, supostamnte, os homens mais velhos têm a capacidade de estabelecer critérios. 0 público, a rua, tende a ser definido como um universo hobbesiano, em que se pressupõe um caos, até que uma hierarquização se estabeleça, hierarquização essa que ocorre, geralmente, a partir da lógica da "casa".

Em contextos mais populares, as famílias e, conseqüentemente, as pessoas que nela se inserem, fazem parte de uma rede de relações sociais, na qual se estabelecem elos de obrigações morais entre as pessoas que aí se alojam e se identificam como sujeitos pertencentes ao grupo. Neste caso, o sujeito nunca é um ser para si, mas um ser para o outro, o que significa dizer que a individualidade não se constitui como um valor, e sim, como o coletivo configurado na família.

Conectadas à discussão sobre os modelos de reprodução social, com base nas reflexões de DUMONT (1993), as noções de indivíduo e pessoa tomam relevo na discussão sobre a modernidade e sobre as ideologias da moderna sociedade ocidental. Para DUMONT (1993), os sujeitos mais individualizados estão associados a contextos mais igualitários e à noção de pessoa, que está enredada a uma totalidade social, à complementaridade, à falta de escolhas e de consciência social. O "indivíduo", característico de sociedades/grupos, em que predominam rituais mais igualitários, faz as regras onde vive, enquanto a configuração de "pessoa", associada a ritos sociais autoritários, recebe as normas de um mundo segmentado.

Na visão de Da MATTA (1990), a noção de "indivíduo", em contraste com a noção de "pessoa", indica aspectos de uma mesma realidade humana 
e revela a dialética do universo social. Quanto mais impessoal, mais igualitário, quanto mais pessoalizado, mais autoritária e hierárquica é a lógica que se estabelece.

Conforme discussão desenvolvida por SARTI (1996), a partir de reflexões feitas por Da Matta (1990) sobre a realidade brasileira, a autoridade do homem é associada ao poder na família, enquanto a mulher está estritamente ligada à casa. Esta divisão se coloca em termos complementares.

Na família dos pobres, segundo SARTI (1996), a divisão complementar entre homem e mulher se dá de forma que o homem corporifica a idéia de autoridade e intervém na relação com 0 mundo externo. Ele é a autoridade moral e garante o respeito. À mulher, cabe manter a unidade do grupo. É a "mulher-da-casa". Com a ausência do provedor-homem há, segundo SARTI (1996), uma perda para a totalidade, que é a família. No entanto, a mulher pode cumprir o papel masculino de provedor e, mesmo nesses casos, não há perda para a identificação masculina da autoridade. Segundo a autora, "Pela forte demarcação de gênero e pelas dificuldades de realização do modelo nuclear, não necessariamente, as figuras masculinas e femininas são depositadas no par pai/marido e mãe/esposa, mas são transferidas para outros membros da rede familiar, reproduzindo esta estrutura hierarquia básica" (SARTI 1996:49)

0 argumento do pacto conjugal, para exclusão do uso da camisinha é, também, utilizado por homens heterossexuais (ALMEIDA 2002). Mediante um escalonamento de riscos, avaliam as condições da mulher com quem poderiam ter uma relação, a quantidade de relações que ela teve, para situála em um campo hierarquizado de risco. Esta lógica, inerente aos homens e mulheres, faz com que o risco de contaminação não seja percebido em alguns casos. A idéia de "monogamia absoluta" é a que marca os discursos. 
A ruptura, com esse discurso, se dá fracamente, e somente nos casos em que mulheres se propõem a refletir sobre a vida conjugal, a condição da mulher e a epidemia da Aids. Implica pensar que o risco está presente em suas vidas, eliminando as fronteiras do risco situado no "outro".

Mesmo no caso de mulheres de escolaridade superior, a camisinha é adotada como método de controle de fecundidade, e não como método de prevenção de DST's. Os acordos firmados desvelam que valem mais as palavras que os atos, no caso da prevenção às doenças sexualmente transmissíveis. A confiança é o argumento central para a prevenção da Aids, como aponta a interlocutora em sua fala:

[De que maneira, como você se sente protegida?] É, eu tenho uma proteção, acho que é de confiança, sei lá, acho que é essa coisa de confiança mesmo, sei lá, se tivermos alguma coisa, a gente vê e, enfim, a gente vai tomar as devidas precauções e realmente é na confiança, eu acho que a gente não... talvez seja até uma coisa interessante a gente sentar e... engraçado, é a coisa da confiança mesmo. É a confiança? Total (Sonia, mulher branca, ensino superior, vasectomia).

Tendo em vista que as mulheres não enfrentam o problema do risco em suas relações conjugais, procuramos verificar em que situação elas recomendariam o uso da camisinha. As afirmações vão na direção de que a camisinha deve ser usada em relações em que não se conhece o parceiro, em suma, em relações anônimas ou em relações em que não se conhece a condição sorológica do parceiro.

[Quando e em que situação você acha que a mulher tem que pedir a camisinha?] Ah, eu acho que sempre. Por exemplo, se você não conhece assim a pessoa, aí tem que ser uma coisa assim obrigatória. 
Se você não conhece, tem que ser uma coisa, meio como escovar os dentes, não pode abrir mão. Depois, se você conhecer melhor, tiver essa abertura de conversar com uma pessoa que assume as coisas, aí até dá para negociar. Fora isso, não negocia. Como disse uma amiga minha: "Se não quer usar camisinha, então não transamos" Seja feliz" Nesse ponto acho que isso (Regina, mulher negra, ensino superior, camisinha masculina).

[Em que situação que a mulher deve pedir o uso da camisinha?] Se for um namorado muito recente. Se for a primeira relação. Se for uma pessoa que não conhece e se tiver alguma dúvida. E se for um marido que não seja muito confiável. [Você teve algum tipo de dificuldade para negociar isso com o seu marido?] Nenhuma, porque tem homem que não gosta de usar, mas o meu marido nunca falou nada e a gente usa como anticoncepcional (Suzana, mulher branca, ensino superior, camisinha masculina).

Como menciona ALMEIDA (2002), homens também apostam no pacto conjugal e na monogamia absoluta, como forma de enfrentamento da epidemia da Aids. O casal faz uma espécie de triagem, em que vão mapeando as relações pregressas do parceiro. Alguns chegam a fazer 0 teste, outros não. Se a possibilidade de contaminação não é encontrada, estabelece-se a confiança no parceiro. Daí para diante, fica acordada a suposta monogamia absoluta que, por vezes, não é respeitada pelo parceiro. Pode-se supor que, sendo a camisinha associada a uma maior autonomia, refere a um determinado estilo de vida, que compreende uma liberdade individual mais ampla do que a usual. 


\subsection{Preocupações com relação a Aids}

A existência da AIDS e a falta de cura para a síndrome têm mobilizado especialistas, com o intuito de se elaborarem novas estratégias de ação educativa e de prevenção das doenças sexualmente transmissíveis, de grande relevância para a área da Saúde Reprodutiva e Sexual. Alguns trabalhos, presentes na literatura especializada, fornecem informações sobre indivíduos ou grupos que seriam mais suscetíveis ou vulneráveis à infecção pelo HIV/AIDS. Como tendência, vale observar a maior preocupação com as mulheres em idade reprodutiva, revelando que a questão de gênero é uma questão central para pensar HIV/Aids.

As principais questões que a AIDS tem suscitado, no campo da saúde, estão ligadas à prevenção e ao seu controle, decorrentes de seu caráter, atualmente considerado pandêmico. Para LOYOLA (1994), a divulgação sobre as formas de contágio não leva, necessariamente, a uma atitude preventiva da população atingida. Afirma, inclusive, que a divulgação das formas de contágio tem estimulado comportamentos mais moralizadores do que, propriamente, preventivos. Em seu trabalho, embora admitindo que sua amostra não permite a generalização para outras populações, ela identifica, no discurso de seus informantes, uma lógica que opõe "promiscuidade" versus "estabilidade" e "normal" versus "anormal" nas relações conjugais. Em outras palavras, uma lógica dicotomizada e mais conservadora, sinalizando que o processo prevenção do HIV/AIDS está a contemplar questões de natureza social e cultural a serem trabalhadas.

A AIDS trouxe, após um período inicial de invisibilidade estatística de casos ocorridos entre mulheres e de falsas concepções sobre a síndrome, graves conseqüências, em especial à saúde das mulheres, tornando-se um 
exemplo típico de como a questão de gênero adquire relevo no campo da Saúde Reprodutiva.

A problemática do HIV/AIDS na vida de mulheres, associada ao conflito, elemento intrínseco às relações de gênero, fazem com que as questões de gênero tomem um caráter central nas discussões sobre formas de prevenção para este grupo. Isto, porque as dificuldades enfrentadas por mulheres referem-se, basicamente, a barreiras de natureza sociocultural, reveladoras de diferentes ordens de conflito no âmbito das relações de gênero. Conforme já observado na área da Saúde Reprodutiva, destaque cabe à necessidade de negociação que, atualmente, a mulher enfrenta, com vistas à prática do "sexo seguro", em que o uso do preservativo constitui 0 desafio.

Na pesquisa de O'LEARY \& CHENEY (1993), o que se apresenta como obstáculo para adesão ao "sexo seguro", como estratégia de prevenção ao HIV/AIDS é, no caso das mulheres, a falta de informação, associada à prática e comportamentos fortemente influenciados por fatores sociais e econômicos, além do caráter imponderável da sexualidade humana.

Do comportamento sexual à necessidade de negociar o "sexo seguro", como estratégia de proteção à saúde das mulheres, à precária condição de vida de alguns grupos de população feminina, somam-se os conflitos de gênero que, finalmente, desvelam-se como obstáculo ao processo de prevenção ao HIV/AIDS. Segundo SIMÕES BARBOSA (1995), mulheres de baixa renda, em parcerias fixas, apresentam maior dificuldade no processo de negociação para o uso do preservativo. Apontando para o fato de que o padrão de infecção crescente da AIDS, nos últimos tempos, é heterossexual, SIMÕES BARBOSA e VILELA (1996) asseguram que a crescente "feminização da pobreza", associada às desigualdades sociais e raciais, podem incrementar as possibilidade de risco ou a vulnerabilidade das mulheres negras e pobres. 
$\mathrm{Na}$ pesquisa sobre HIV/Aids, de SANTOS (1994), a maioria das mulheres infectadas, no período de 1983 a 1992, era de baixa escolaridade e de ocupações não qualificadas. O uso de drogas é apresentado como um fator importante na transmissão do HIV entre mulheres de baixa escolaridade, seja por intermédio de parceiros, ou como usuária.

Pensar a questão a partir da idéia de uma concepção de risco e prevenção, no contexto de mulheres de baixa renda, impõe a necessidade de se observarem determinadas especificidades pertinentes ao grupo. Segundo SIMÕES BARBOSA e VILELA (1996: 24), "se partimos do princípio de que a adoção de uma atitude preventiva frente à possibilidade de infecção pelo HIV depende da informação sobre esta possibilidade, da identificação dos riscos pessoais, que cada um está exposto e da capacidade de proteção que cada um desenvolve, temos que admitir uma equação bastante complexa e intermediada por fatores de magnitudes diferentes, a que cada mulher se apresenta, de maneira particular, em função de sua biografia, de sua subjetividade, de sua inserção de classe". A idéia de vulnerabilidade coletiva e individual, conceito oriundo da área de Direitos Humanos, com 0 crescimento do HIV/Aids, na população, em contraposição a medidas de risco, adquire importância no contexto atual para a análise da questão (AYRES et al 1999).

Ao lado da questão relativa à prevenção e aos cuidados da saúde das mulheres, de modo geral, a transmissão vertical, que é um risco para mulheres (e filhos) que são casadas, ou que vivem "maritalmente", bem como para adolescentes, pela dificuldade no uso do preservativo, faz da questão da Aids algo ainda mais grave. Mulheres em idade reprodutiva, infectadas pelo HIV/Aids, têm gerado muitos órfãos, que sobrevivem, muitas vezes, de forma dramática, de acordo com LA GUARDIA (1991) e O'LEARY \& CHENEY (1993). A questão da negociação entre mulheres e seus parceiros, para uso do preservativo, assume grande importância, à medida que se trata de proteger, igualmente, os filhos do casal. Neste sentido, a 
negociação e o uso do preservativo constituem questão crucial para a proteção da saúde da mulher e de suas crianças.

Diante desse quadro, é que autores, como SIMÕES BARBOSA e VILELA (1996), por reconhecerem a necessidade de as mulheres negociarem com seus parceiros o uso do preservativo, defendem a idéia de que os programas de "planejamento familiar", ou de "contracepção", deveriam ser repensados, com a finalidade de incorporarem a problemática da Aids. Considerando que o uso do preservativo é o único método de prevenção do HIV/Aids, assim como uma das formas de contracepção, torna-se fundamental para o delineamento desses programas que preservativos sejam destinados, não somente às mulheres mas, igualmente, aos homens.

Embora não exista uma bibliografia extensa que pense a questão de gênero e raça na questão da Aids, em função dos dados que informam a maior exclusão da população negra, pensamos que isto seja relevante. Articulação da questão de gênero e raça, no campo da saúde reprodutiva, parece evidente. Localizamos, em nossa pesquisa bibliografica, os trabalhos, já mencionados anteriormente, de LOPES (2003), que analisou a vulnerabilidade de mulheres portadoras do HIV/Aids, segundo cor, e de BATISTA (2002), que verificou maior letalidade da Aids na população negra. LOPES (2003), estudando a vulnerabilidade de mulheres negras e não negras portadoras do virus do HIV/Aids, BATISTA (2002), analisando padrões de mortalidade na população de São Paulo, segundo cor, e SOUZA (2002), estudando questões relacionadas a miomas uterinos, como referimos anteriormente, verificaram desvantagem para a população negra. GUALBERTO (2003) verificou, no geral, que mulheres negras são, em menor proporção, usuárias de métodos e, quando optam por um, têm maiores chances de optarem pela esterilização. Isto, possivelmente, confere maior vulnerabilidade para as mulheres negras que, em sua conjugalidade, devem negociar o uso da camisinha. 
8.4.1 A mulher negra laqueada e não usuária da camisinha

A Aids é uma preocupação mediada por diferentes estratégias de enfrentamento da questão. A principal delas é estabelecer um acordo de monogamia absoluta. Entre mulheres negras e brancas, preocupações com relação à Aids, no seu relacionamento conjugal, são combatidas com a confiança. Este é um elemento importante para a exclusão do uso do preservativo.

O risco de contaminação apresenta-se como uma possibilidade na relação, se o companheiro quebrar a relação de confiança, ou o pacto de fidelidade. A palavra vale mais que atos e é depositado, nas mãos dos homens, o destino do casal. Nesse sentido, mulheres negras, laqueadas, perdem a possível autonomia, para depositarem na mão dos homens a chave do seu destino. A figura da roleta russa serve bem para ilustrar a situação em que ficam as mulheres, mediante a possibilidade de risco de contaminação.

Referimo-nos, anteriormente, ao trabalho de BATISTA (2002), que constata uma maior mortalidade negra nos casos de Aids, e o trabalho de LOPES (2003), que constata a maior vulnerabilidade de mulheres negras nos casos de Aids. Nesse sentido, a situação da mulher negra é polêmica, por um lado, e dramática, por outro. Essas informações agregam maior preocupação em relação a mulheres que, laqueadas, excluem o uso da camisinha.

Tendo refletido sobre a temática da saúde reprodutiva das mulheres e constatado que existem nuanças que não são esclarecidas, meramente, pela condição de classe; e, mais especificamente, que a questão da contracepção necessariamente passa, por um lado, pela "cultura da esterilização" (BERQUÓ 1994), disseminada, indistintamente, entre mulheres, de modo geral, e por outro, pelo quadro descrito por GUALBERTO (2003) em que a menor autonomia da mulher está relacionada à escolha de seu método contraceptivo, e nisso, a mulher negra desponta com maiores chances de 
escolher a esterilização, vis-à-vis métodos tradicionais ou métodos femininos, fica evidente que esse cenário coloca, sob foco, a mulher negra, razão pela qual fomos buscar seu discurso.

Eu fico pensando, você está aí na vida. Você não fez um pacto de fidelidade. Mas aí, de repente, seu marido dá uma escorregada. Mas eu já falei p'ra ele "Se você der uma escorregada, você usa camisinha". Mas se ele não gosta de usar camisinha? Então você nunca sabe. Não é? Você fica aí na roleta russa (Hortênsia, mulher negra, ensino superior, laqueada).

A introdução da camisinha seria complicada, por significar a perda da confiança e a quebra da cumplicidade entre os pares. Tais eventos podem levar a uma dissolução da união. Sendo assim, mulheres negras, que optaram por métodos radicais, como a laqueadura, enfrentariam maiores dificuldades de introduzirem o uso da camisinha na sua relação, mesmo percebendo que houve quebra na confiança e infidelidade do parceiro.

\subsection{0 pacto conjugal}

O pacto conjugal prepondera na maioria dos casos de exclusão do uso da camisinha. Diríamos que, em raros casos em que há a desconfiança com relação ao parceiro, o pacto conjugal, baseado na confiança, é o argumento central para exclusão do uso da camisinha em todas os grupos de escolaridade e cor. Este pacto é explicitado por Sara.

[Por que você não utiliza?] Eu tenho uma confiança. É assim: a gente tem um pacto, desde que a gente se conheceu, que antes da gente trair, a gente vai falar um para o outro que a 
gente não quer mais. Então, para gente sempre foi assim. A traição quer dizer que acabou, quer dizer que você foi buscar uma coisa que você não tem mais aqui. A gente sempre pensou igual. Eu já fiz exames de Aids. Eu já fiz três. Meu ginecologista sempre pediu. Ele acha que não interessa se é um parceiro só (Sara, mulher branca, ensino superior, tabelinha).

A constatação da infidelidade é o termômetro, que aponta que a mulher deve adotar o uso de preservativo na sua relação. A necessidade de uso do preservativo, então, indica um tipo de relação, em que a confiança não está presente e há a impossibilidade de um pacto conjugal.

No dia de hoje, como que... que nem, não é porque é marido, que a gente vai falar:"Ah, é marido, não vai usar camisinha", é principalmente com o marido que tem que usar camisinha porque, o meu caso, eu tenho que usar camisinha. Porque, que nem eu já fui, como já fui traída, estou sendo traída, fui traída, então é bom usar camisinha. Você não sabe qual é a mulher que ta...está saindo com ele, não é? Então, eu, no meu caso, é muito importante (Dalila, mulher negra, ensino fundamental, está descansando do uso da pílula).

Os pactos conjugais são continuamente revistos, como indicam SOUZAS e ALVARENGA (2002), e re-estabelecidos em bases factíveis com a relação. A troca de método contraceptivo pode entrar na dinâmica da relação conjugal, como algo a ser negociado. A camisinha, ao contrário da laqueadura, é utilizada por mulheres que desejam uma menor intervenção em sua saúde reprodutiva, e se caracteriza por ser um método que se adapta melhor aos relacionamentos sexuais e afetivos mais flexíveis. A 
laqueadura e a pílula, como aponta OSIS (1999), são métodos de uso prevalentes, no Brasil, a eficácia é usada como argumento para reiteração do uso, sendo que outros métodos, também eficazes, não são levados em conta. 


\section{A CONJUGALIDADE DE MULHERES NEGRAS E BRANCAS}

A relação conjugal abarca várias formas de cuidado, consigo mesmo e com o outro. Nessa teia de relações e, mais especificamente, de cuidados, constrói-se a cumplicidade, que se expressa em uma dada conjugalidade. Somado a isto, o discurso sobre a vida sexual nos oferece a oportunidade de conhecermos em que medida se dá a cumplicidade do casal. Estamos, aqui, no terreno da intimidade que, segundo GIDDENS (1993), tem passado por profundas transformações sociais. A principal delas é relativa às relações de gênero. Os papéis sexuais passaram a ser mais negociados, no cotidiano, deixaram de ser pré-estabelecidos, e rompeu-se com a idéia de que a biologia determina o destino das pessoas. Nesta parte da tese, buscamos demonstrar, através do discurso, como as mulheres investigadas apresentam a sua conjugalidade e, nesse aspecto, a diferença observada entre negras e brancas.

Para pensar uma aproximação a essa idéia de transformação, analisamos a conjugalidade, observando, em um primeiro momento, aspectos relativos à relação conjugal, quais sejam, quem toma as decisões, cuidado com a casa, com os filhos, assim como a gestação, para depois, em um segundo momento, abordarmos a questão da sexualidade na vida das mulheres entrevistadas.

\subsection{Vida conjugal}

Quando perguntamos sobre a vida conjugal, a questão da infidelidade aparece no discurso de mulheres brancas, de ensino fundamental, como um problema associado à rotina do relacionamento conjugal. A conjugalidade deixa de ser um campo de confiança no comportamento monogâmico do parceiro, para enfrentar o problema da 
infidelidade. A fórmula para a prevenção de DST's/Aids, que, no caso das mulheres entrevistadas, é baseada na confiança no parceiro e na idéia de monogamia absoluta, deixa de ser eficaz, já que ao homem é atribuída a infidelidade. Pesa no discurso de Denise (mulher branca, ensino fundamental, não usuária de nenhum método) a idéia de culpa, pela rotina, e até mesmo, pela infidelidade masculina. Esta recai sobre a mulher, a quem é atribuída a incapacidade de se tornar sexualmente atrativa para o homem, dado que SOUZAS e ALVARENGA (2001) também observaram no discurso de mulheres de baixa renda, em São Paulo. Com relação à fidelidade, ela (Denise) afirma:

Não existe homem fiel. Hoje em dia não tem. E a culpada é a mulher, porque ela coloca uma rotina muito rigorosa, mesmo que ela não queira, ela põe. Ela tem que ter tipo, mesmo que ela tem aquela coisa com ele, ela tem que ser uma prostituta, ela tem que carregar ele pela mão para fazer outras coisas junto. E assumir um pouco (Denise, mulher branca, ensino fundamental, não usa nenhum método).

Mulheres negras destacam, em seu discurso, que o controle sobre a vida de um, e de outro, tem mão dupla e, quando a mulher está em casa e não trabalha, como é o caso da maioria das mulhers negras, de ensino fundamental, o homem tem um maior controle sobre as ações da mulher, o que faz com que sua vida seja limitada, em termos de espaço e de liberdade de ação. Uma "insubordinação" da mulher ao homem pode se fazer presente, como podemos observar no discurso de Eliane:

Ah, existe aquele fator assim.... se eu saio, ele não gosta que eu saio. Aí, eu não escuto o que ele fala, porque eu acho que homem não tem que mandar tanto em mulher. A não ser que ele veja alguma coisa errada. Aí, eu termino saindo. Quando volta, é uma briga, ou então, ele gosta de sair com os amigos 
p'ra tomar uma cerveja e eu não gosto. Aí é outra briga. E quando está perto daqueles dias, é pior. Porque aí não pode nem chegar na porta e olhar na minha cara, porque eu já meto grito. Mais,vamos levando, vamos levando (Eliane, mulher negra, ensino fundamental, laqueadura associada à camisinha).

Existem inúmeros obstáculos que são enfrentados na união conjugal, sendo, muitas vezes, responsabilizadas as mulheres pela manutenção, sucesso ou francasso da união. Como aponta FOUCAULT (1997), e a nossa interlocutora, às mulheres, em união conjugal, cabe um comportamento que "fecha os olhos" para os desvios que o marido possa cometer. Esse comportamento tradicional de mulheres apresenta-se no discurso.

Ah porque é difícil casamento, porque quem mais segura é a mulher, é a mulher que mais fecha os olhos, é a mulher que mais deixa passar coisas (Pámela, mulher negra, ensino fundamental, laqueada).

Quais problemas mulheres, de ensino fundamental, negras, enfrentam para manter um bom relacionamento? No enfrentamento de problemas de relacionamento, novamente, o discurso da confiança reaparece, como aquilo que dá à união a possibilidade da existência conjugal. Há uma certa educação sentimental para o relacionamento conjugal, um processo de adaptação implícito mantém o relacionamento conjugal.

Olha, se você casa com uma pessoa e desde o começo ele gosta de farrear com os amigos, você não vai conseguir tirar ele daqueles amigos, é muito difícil. Se ele gosta de beber, p’ra tirar ele daquele meio também é difícil. Então, às vezes, você tem que passar por cima de muita coisa. Então, se você arruma um marido bonitão, que é meio paquerador, é difícil você controlar certas coisas. Você tem que ter 
confiança na pessoa. Se você não tem, não consegue levar o casamento p'ra frente. E nem sempre você deve levar a ferro e fogo entre brigas, porque às vezes você está errada. E aí, você termina discutindo, levando a ferro e fogo, aí seu casamento vai por água a baixo. E tem que haver uma grande confiança entre os dois. $E$ também conversar sobre tudo, quando envolve os filhos, principalmente (Eliane, mulher negra, ensino fundamental, laqueadura associada à camisinha).

A união conjugal pressupõe uma descontinuidade no tipo de liberdade que as pessoas experimentavam na vida de solteiro. Entretanto, a passagem de um estado a outro implica perda de alguma liberdade, para homens e mulheres. Neste jogo, cabe às mulheres negociarem em que medida farão concessões, ou não:

Ah, os problemas são os marido mesmo. Os maridos gostam de liberdade e se as mulheres não querem dar essa liberdade que eles querem, aí o casamento não vai bem, aí só fica brigando, aí eles chegam tarde, aí eles discutem. Agora, se chega tarde, elas não falam nada, o casamento vai ótimo. P'ra mim, o problema do casamento é o próprio homem (Pámela, mulher negra, ensino fundamental, laqueada).

Percebemos, no discurso de mulheres, de ensino fundamental, o quanto Ihes é difícil manterem a idéia da monogamia absoluta, que discursam como o elemento para a exclusão da camisinha e, ao mesmo tempo, assumirem a atribuição da grande responsabilidade pelo fracasso da união. Tudo sobrecarrega as mulheres, que devem "cumprir com a sua obrigação". A fala de Gorete, abaixo, expressa a relação de dever com a casa e com o próprio marido, que as mulheres mantêm. 0 diálogo e a compreensão entre os pares é algo almejado por mulheres que não possuem 
isso em suas relações. São relações que, para existirem, exigem muita concessão das mulheres e resultam, em nível do discurso, do egoísmo dos homens, como apontado a seguir:

A compreensão, os homens não têm isso. São raros os casos assim, que o casal se entende por completo. Falta muita compreensão, muito egoísmo, sabe? 0 homem só pensa nele. Acha que a mulher tem que ficar vinte quatro horas na cozinha, cuidando de filho, cuidando de casa, não dá nada em troca (Gorete, mulher branca, ensino fundamental, laqueada).

Mulheres negras, de ensino médio, relatam relações que elas consideram boas, sem problemas com o parceiro, e nas quais afirmam a existência de uma cumplicidade com os mesmos.

Eu acho que é um... é normal. É um... é um... é um relacionamento normal, com muito respeito, não é? Acima de tudo, muito amor, não é?, a gente...a gente está casado há quase dezesseis anos, e eu sinto isso. Não é? A gente tem as nossas... desavenças, às vezes, discussões, lógico, a gente... um não é igual ao outro, mas a gente tem muito respeito um pelo outro. Então, eu acho que é uma relação boa. É uma relação muito boa (Amanda, mulher negra, ensino médio, histerectomizada).

A proximidade do casal e a possibilidade de diálogo parecem reforçadas nas uniões de mulheres brancas, de ensino médio:

Ah, eu acho que a gente tem uma cumplicidade muito grande, talvez pelo fato de eu ter casado muito nova e ele também, a gente cresceu junto. Então, muitas coisas eu aprendi com ele, muitas coisas ele aprendeu comigo, e a gente teve muito, tem muito a questão do companheirismo, de estar dividindo as mesmas coisas, de ter vontade de dividir, quando acontece alguma coisa comigo eu tenho vontade de 
conversar com ele, ele também ( Carla, mulher branca, ensino médio, vasectomia).

O problema que as mulheres vêem, com relação ao casamento, diz respeito ao que podemos chamar de uma "submissão voluntária", para que não se perca a relação conjugal:

Eu acho que a maioria das esposas, elas fingem que não vêem as coisas... para tentar levar um casamento feliz. Tipo assim: o marido [...] faz muita coisa que elas não aceitam, mas elas não brigam com eles, com medo de perder. Eu conheço vários casos (Marina, mulher negra, ensino médio, não está usando nenhum método).

Enquanto a mulher negra, acima, revela problemas relativos à manutenção do relacionamento, a mulher branca, abaixo, aponta problemas com relação a uma postura frente à relação, que se revela mais ativa. A diferença está na liberdade de se colocar frente ao outro, de modo a ter a sua individualidade respeitada:

Eu não sei nem se é questão de discordar, mas de um levar mais na boa e o outro ser mais rígido, entendeu, não em si de brigar por causa deles, eu acho assim, é algo que, os problemas eles são, quando tem problemas é mais de um pro outro, de não estar conseguindo encontrar, mas a gente tem bastante discordância de pensamento, de postura de vida, de forma de ação, porque eu, por exemplo, eu sou mais, eu sou muito sincera com os meus sentimentos, explosiva, mas essa explosão passa logo e, se eu tiver que pedir desculpas, eu peço, pros meninos mesmo, eu não sou rígida, eu sou mais maleável, ele é mais dócil, porém firme, assim ele não arreda pé e nem pede desculpa, mesmo sabendo que está errado, é mais duro, então eu acho que isso é uma coisa que, acho que dá bastante discordância entre a gente ( Carla, mulher branca, ensino médio, vasectomia). 
A individualidade parece ser a grande questão, presente no âmbito da conjugalidade, pois, dependendo da forma de união conjugal, ela pode ser anulada, e a mulher fica sem uma forma de expressão das suas vontades frente ao parceiro. Mulheres brancas, de ensino médio, parecem ter mais esta possibilidade, na sua relação, do que mulheres negras, de ensino fundamental e médio, e brancas, de ensino fundamental. A questão é como se dá o diálogo entre os pares, que é fortemente percebida entre as mulheres de ensino superior. Neste segmento, as mulheres expressam mais suas vontades e têm maior liberdade de expressão da sua individualidade, frente ao parceiro.

Maior flexibilidade na relação conjugal é percebida, e as mulheres podem atender melhor às suas necessidades e conciliar, com o seu desenvolvimento pessoal, as tarefas e obrigações do cotidiano. A mulher, de nível superior, pode negociar melhor sua entrada no mercado de trabalho e, mesmo ficando em casa, pode continuar envolvida em atividades de sua escolha e prazer.

Olha, a gente definiu no meu casamento, quando nós tivemos filhos, que eu ia continuar a trabalhar e terminar a faculdade e tinha que cuidar da minha filha. Aí, eu não conseguia mais trabalhar, estudar e cuidar da minha filha. E aí, na prática, a gente ficou definido o seguinte, meu marido ia continuar trabalhando e estudando e eu continuei trabalhando um pouco bem menos e podendo estudar em casa e cuidar mais da, mais da minha filha. Foi assim que a gente organizou o casamento, foi assim que a gente foi levando. Até que eu pude voltar a trabalhar mais horas e estudar mais, fazendo outros cursos. Ele também terminou a etapa dele. Foi assim que a gente organizou nosso dia a dia para que nós conseguíssemos sobreviver (Roberta, mulher negra, ensino superior, camisinha masculina). 
A melhor comunicação entre os pares é percebida entre as mulheres de nível superior. Esta é uma condição para a melhor negociação diária dos acordos a serem firmados.

O meu dia-a-dia é bastante corrido, é bastante agitado, meu companheiro é bastante parceiro, eu acho que mesmo diante dessa maluquice toda a gente consegue se comunicar, que eu acho que é 0 grande desafio dos casamentos atuais, eu acho que a comunicação é tudo dentro de um relacionamento. Então, eu acho que a gente consegue se comunicar, mesmo na correria a gente se fala bastante, eu acho que a gente se ajuda muito. O A tem uma parte do dia dele livre, então ele tenta me atender naquilo que é possível dentro dos meus interesses, que passam a ser os nossos interesses, então dentro do Instituto ele se envolve, eu acabo não me envolvendo tanto no trabalho dele que é uma coisa muito mais específica e não me chama, não é, não tem espaço p'ra que eu possa entrar, mas eu acho que a gente consegue ter uma relação harmônica apesar do pouco tempo, apesar da correria eu acho que a gente consegue abrir um espaço p'ra ficar juntos, acho que a gente consegue abrir um espaço p'ra sair, pelo menos uma vez por semana, relaxar, tomar alguma coisa sozinhos, mesmo que seja meia noite, mesmo que seja onze e meia, mesmo que seja uma hora da manhã, como a gente fez, por exemplo, no sábado, então assim acho que a gente tem uma relação boa (Sonia, mulher branca, ensino superior, vasectomia).

Um relacionamento mais dialogado é o que apresentam as mulheres de escolaridade superior, também, cumplicidade pautada na negociação cotidiana. Sintomaticamente, a interlocutora, a seguir, que é laqueada, aponta que o diálogo, ou, a ausência dele, define tudo na vida de um casal, além, é claro, de explicitar as condições nas quais se dão as relações de gênero: 
Eu acho que falta de diálogo, a falta de divisão igualitária de tarefas. Acho que só isso, falta de diálogo, falta de divisão. [Diálogo sobre 0 quê?] Ah sobre tudo, acho que você tem que conversar sobre tudo. Sobre o que você vai fazer com os filhos. É sobre o que você espera da relação, sobre o que você não espera. Acho que sobre tudo (Hortênsia, mulher negra, ensino superior, laqueada).

A visão romântica das relações conjugais seria um problema importante, a ser considerado, como obstáculo para as relações conjugais:

Eu vejo não uma questão de informação, mas é questão de formação. Acho que as pessoas ainda são muito românticas. 0 marido resolver tudo, você tem um homem que te completa, não que te completa, mas que te proteja. Tem isso ainda, uma coisa muito romântica por parte das mulheres, com relação ao relacionamento (Regina, mulher negra, camisinha masculina).

A flexibilidade da relação conjugal frente aos dilemas do cotidiano, é o que apresentam as mulheres de nível superior. É a presença da expressão da individualidade frente à conjugalidade. Apresentamos o discurso da interlocutora, abaixo, que aponta a falta de tempo, como um problema para a sua relação conjugal. 0 tempo para 0 amor, e para a família, são espaços de vida negociados e acordados entre os pares.

Eu acho que, no meu caso, que foi problema para mim é a falta de tempo. Isso que eu te falei da liberdade e tal que a gente começa precisar: quero trabalhar, estudar, fazer tudo e o marido, também, trabalhando, fazendo tudo. Você acaba não tendo tempo para o relacionamento. E esse tempo não pode ser um tempo que você determina, tem que ser um tempo que você volta p'ra casa, tem que ter calma, não tem que pensar em trabalho, em outras coisas. Eu percebo que, quando eu abri mão de ficar aqui, por exemplo, foi aí 
que eu ganhei nesse sentido assim familiar. Porque a gente trabalhava muito e acabava brigando muito. Muito mais cansada, se não sabe para o quê você vive. E eu estava indo também nesse ritmo. Aí foi quando eu percebi, olha, não sei se vale a pena. E parei um pouco de trabalhar, fiquei só estudando, depois só trabalhei um período. Quer dizer, sempre acabei deixando períodos para ficar mais em casa. E isso ajudou muito. Porque melhora o relacionamento. P'ra mim, foi o melhor jeito. Não sei, depende de cada relação (Roberta, mulher negra, ensino superior, camisinha masculina).

Nos relacionamentos em que os pares são mais flexíveis, a questão da liberdade do outro é super valorizada, de modo que, se há um desrespeito à individualidade, a relação é ameaçada. É como se os casais, em termos de relacionamento, tivessem optado pela busca do equilíbrio, em bases não tradicionais.

Mas, como os casais negociam atividades cotidianas e como exercitam essa compreensão de liberdade? É interessante observar que no campo da administração do lar, de modo geral, entre mulheres de ensino fundamental, médio e superior, brancas e negras, quem toma decisões, com relação à casa, são as mulheres, com alguma participação de maridos e companheiros. Embora eles sejam considerados, na sua maioria, os chefes da família, por que provêm a maior parte do sustento da casa, deixam as decisões, com relação ao lar, às mulheres.

A colaboração, por parte homens, nos cuidados da casa, é pequena, segundo mulheres brancas e negras, de ensino fundamental, e negras, de ensino médio. Cruzando-se esta informação com a de decisão nos assuntos do lar, reforça-se a idéia de que os cuidados e gerenciamento da família são encargos das mulheres. 
Ele me ajuda nas coisas de casa quando eu estou em casa, no sábado ou domingo, que eu preciso dele p'ra me ajudar, precisa levar em tal lugar. leva. Dificilmente ele ajuda as crianças, quando ele está só em casa. Só se eu falo "Você faz isso e isso" (Gorete, mulher branca, ensino fundamental, laqueada).

As mulheres brancas entrevistadas, de ensino médio, seguem um outro padrão, que é mais próximo ao de mulheres brancas, de ensino superior. Entre elas, o marido colabora mais nas atividades de casa, e os filhos entram na relação, recebendo cuidado de ambos os pais. A atenção dedicada à casa, pelos companheiros, é relativamente maior neste grupo, que se destaca dos outros segmentos, reforçando a idéia de que as relações neste núcleo sejam mais igualitárias. A idéia presente é a de que mulheres e homens devem ter igual atividade junto à casa e aos filhos, ou melhor dizendo, dentro de padrões em que a individualidade é mais valorizada.

Com a gente, eu vejo que é bem dividido mesmo, agora eu vejo que tá um pouco mais complicado, até pela falta de tempo que a gente tem um com o outro, pelo fato de trabalhar demais, de ficar tempo demais em trânsito, de os filhos estarem crescendo, então, a intervenção deles no relacionamento é maior, até então, a gente tinha tudo muito definido assim, de que somos seres individuais e que precisamos de espaços individuais e conjunto com cada um, junto os quatro, e separado um do outro (Carla, mulher branca, ensino médio, vasectomia).

No grupo de mulheres, de ensino superior, é mais comum ter a empregada cuidando da casa. Freqüentemente, uma empregada-mulher substitui a esposa nas tarefas cotidianas. Embora o lugar de quem é responsável pelo cuidado da casa seja, simplesmente, substituído por outra mulher, o homem-companheiro partilha, de alguma forma, as tarefas da casa e o cuidado com os filhos, quando há. Não existe uma divisão rígida de 
papéis sexuais e divisão do trabalho. Não queremos dizer, com isso, que houve uma transformação da divisão sexual do trabalho. 0 que acontece é que a mulher pode dividir mais com outra mulher-empregada e que os homens, em alguns casos, participam mais do cuidado dos filhos e das tarefas domésticas.

As mulheres, nos casos analisados, são profissionais de nível superior, que ocupam postos de trabalho, ou não. Mesmo assim, quem administra a casa é a mulher. É ela que comanda a empregada e quem controla as atividades relativas aos filhos e à casa. Os homens cumprem uma tarefa que é de auxiliar, embora, em alguns casos, desempenhem realmente o papel de cuidador.

[Como é o dia a dia, tem uma boa divisão tarefas dos compromissos?] Tem, se bem que eu acho que sempre sobra mais para a mulher. Se bem que a gente procura... o F. me ajuda muito. Eu falo que eu reclamo de barriga cheia. Mas eu queria que fosse igual. Eu acho que tinha que ser tudo divididinho, tudo igual, engraçado, isso porque eu sinto que antes do $G$. nascer era mais dividido, depois que $0 \mathrm{G}$. nasceu, não sei se por causa dessa coisa de mãe tomar a frente, de mãe ir atrás... Não que ele.. ele me ajuda muito. De ir em supermercado, de cuidar do G., quando tem que dar banho, mas tudo tem que ser muito pedido, ele não tem essa.... (Valéria, mulher branca, ensino superior, DIU).

A diferença entre as mulheres, de nível superior, está na presença ou ausência de filhos. Quando os filhos nascem, as mulheres ficam mais sobrecarregadas com as atividades, com as crianças, com a casa e com 0 trabalho fora do lar. A saída, conforme já observado é, comumente, colocar uma empregada, que auxilia as mulheres nas principais tarefas, e o homem atua como auxiliar nesse processo. No caso de mulheres sem filhos, a saída 
pela empregada é acionada para reduzir a sobrecarga de trabalhos domésticos.

É assim, a gente tinha uma faxineira que vinha uma vez por semana e aí sobrava bastante coisa p'ra gente fazer em casa. Então, a gente dividia muito, tudo. Mesmo porque, uma coisa que sobra muito p'ras mulheres, que é cozinhar, eu não tenho esse problema, porque o $\mathrm{B}$. adora cozinhar. Então, isso a gente divide, eu cozinho, ele cozinha também. E no mais, limpar a casa, arrumar a cama, os dois fazem. Agora, a faxineira vem um dia a mais. Então, sobra menos coisas p'ra nós fazermos. Mas, ele faz igual a mim. Mesmo porque, tem uma coisa que favorece, ele já tinha morado sozinho antes. Até quando eu vim para São Paulo, a V. (irmã) não morando mais aqui, o B. estava morando sozinho. Ele cuidava da casa dele. Acho que é diferente de um cara que saiu da casa da mãe e entrou num casamento, num relacionamento. Eu acho que é difícil p'ra o homem mesmo, ele nunca fez, não sabe. Mas assim, e o B. tem uma mãe que, certamente, ensinou ele a fazer as coisas de casa. Isso é tranqüilo. Ambos fazemos. Nem só ele, nem só eu (Luísa, mulher negra, ensino superior, camisinha masculina).

Os filhos demandam trabalho e organização do casal para o cuidado e educação. Entre mulheres negras e brancas, de ensino fundamental, e negras, de ensino médio, o cuidado com os filhos ficam a cargo das mulheres. Entre mulheres brancas, de ensino médio, e brancas e negras, de nível superior, o cuidado com os filhos é mais dividido. Somente uma das mulheres negras, de ensino superior, teve filhos, as outras cinco não tinham filhos. Neste caso, o marido participava ativamente do cuidado com os filhos. Nos casos em que havia maior participação do marido, o homem auxiliava no cuidado, às vezes, executando concretamente algumas tarefas, como dar banho, dar comida, trocar a fralda. Quando há uma pessoa que faz essas 
tarefas, como no caso das mães, de nível superior, que trabalham fora, o pai é auxiliar na administração dos cuidados. Em suma, o homem assume um papel secundário nas tarefas de cuidado dos filhos. A principal idéia é que os homens participam, de alguma forma, do cuidado e gerenciamento das atividades com os filhos. Esta participação é maior, ou menor, em razão de a mulher trabalhar, ou não, fora de casa.

\section{2 A sexualidade de mulheres negras e brancas}

A sexualidade plástica coloca-se como expressão da individualidade e caracteriza casais modernos. Quanto maior a flexibilidade entre os pares, maior a expressão de uma individualidade imersa em um novo contexto de gênero, que não dicotomiza os papéis sexuais e, ao contrário, possibilita a experimentação de novas configurações de gênero. Segundo GIDDENS (1993:10), a sexualidade plástica é aquela "descentralizada, liberta das necessidades de reprodução. Tem suas origens na tendência, iniciada no final do século dezoito, à limitação rigorosa da dimensão da família; mas, torna-se, mais tarde, desenvolvida como resultado da difusão da contracepção moderna e das novas tecnologias reprodutivas".

Tal sexualidade é o âmago da intimidade, que GIDDENS (1993) acredita estar se transformando e se tornando mais democratizada, principalmente, em razão da atividade das mulheres, que se constituíram nos principais agentes de transformação da vida cotidiana. Com a sua gradativa inserção no mercado de trabalho e na vida pública, as mulheres saíram da prisão doméstica para se tornarem sujeitos sociais e políticos de transformação da vida social.

As mudanças nos padrões de fecundidade configuram este quadro desenhado por GIDDENS (1993). De acordo com CAMARANO, ARAÚjO e CARNEIRO (1999), o declínio da fecundidade é uma realidade, historicamente observável, para as cinco regiões brasileiras, no século XX. 
A despeito de essa queda da fecundidade ter se dado de maneira progressiva e regular no contexto brasileiro, revelando a perversidade da nossa realidade, como o abuso de cesáreas para a prática da laqueadura tubária, temos, hoje, um quadro de fecundidade diferente de décadas atrás.

A transformação da intimidade, como refere GIDDENS (1993), só se realiza para algumas mulheres, que conseguem ter, no seu cotidiano, uma negociação com seus parceiros, que permitem acordos para uma vida sexual e reprodutiva mais saudável.

Segundo PARKER (1991), existe o dado de que, na cultura sexual brasileira, a violência é um elemento construtor de hierarquias, que estão em nossa memória. A autoridade, na figura do patriarca, simboliza a regulação das relações no âmbito da família e, através da violência, constrói a hierarquia das relações familiares, que compreendem relações legítimas, no âmbito da casa, e ilegítimas, no âmbito do engenho. As relações legítimas com mulheres de pele clara, e as ilegítimas, com as de pele escura. Hierarquizadas pela violência, expressam-se na linguagem para falar do corpo. Nesse sentido, mulheres negras são preteridas, em relação às brancas, para o casamento, como observa BERQUÓ (1986), e colocadas no lugar de objeto sexual de homens brancos. Este é mais um dado, com o qual mulheres negras têm que lidar na sua negociação cotidiana da vida sexual e reprodutiva com seus parceiros.

Com relação à sexualidade, não foi possível apreender diferenças no discurso de mulheres negras e brancas, antes, foi possível apreender os mesmos tabus, relativos a algumas práticas sexuais. Observamos, nos depoimentos, a vida sexual dos casais e, mais propriamente, como a intimidade se expressa. A sexualidade é uma temática que gera algumas controvérsias, com relação a praticas sexuais. De modo geral, mulheres explicitaram que a vida sexual não tem grandes novidades, "é normal" como de todos os casais. Existe um certo discurso de monotonia e rotina, como aponta a interlocutora, abaixo: 
Já foi melhor... já foi melhor. No começo, até que era legal. Aquela coisa assim... como é que eu posso te explicar... de carícia, de... porque eu acho assim: no sexo não é só... você transar e pronto. Na minha opinião, tem que ter bastante, primeiro, carinho, sabe? Aquele aconchego gostoso, aquela coisa legal; não adianta você só chegar lá, fazer e pronto. Não tem graça. Não é... você não é objeto, não é?, você é...você é uma mulher, você sente, seu corpo sente. Então... é uma... o... no começo, era bem mais carinhoso. Apesar que não é ruim, não vou falar que é, mas assim, no começo era mais... como eu posso explicar... era... uma coisa assim... de... carícia, de bom, uma coisa boa. Agora, não é... agora virou monótono; tanto faz, tanto fez... se quer, quer; se não quer... não... virou... virou, tipo assim, rotina. P'ra mim, tanto faz, tanto fez... Acho que não tem mais aquele... entusiasmo que tinha... não é?, com as coisas que passam na vida, com os anos [que] vai passando... apesar que eu tenho dado tempo assim; mas tem coisa que acontece que acaba, não é?, aquela... aquela atração, sei lá; aquela coisa que tinha antes. Entendeu? Mas parece que tá bom (Sabrina, mulher negra, ensino fundamental, extraiu as trompas).

Algumas mulheres relatam que o romantismo dos tempos iniciais da relação se perdeu, ou os filhos ocupam um espaço, que dificulta a intimidade do casal, em alguns casos.

Não é das melhores (risos)... é que nem eu te falei, mas eu acho que a culpa é minha... porque é assim, um fica esperando pelo outro... Eu acho que tinha que ser assim, mais romântico, não (faz um gesto com as mãos - bate as costas da mão direita na palma da mão esquerda - que indica uma coisa automática, feita sem maiores cuidados, mecânica (Maria Wilma, mulher negra, ensino médio, estava grávida). 
A monotonia é enfrentada, entretanto, com criatividade e vontade de mudar o script sexual que preconiza a rotina e o desinteresse, quanto maior é o tempo da relação conjugal. Ainda assim, para algumas mulheres, existe um certo desgosto pela vida sexual atual.

Eu procuro fazer criações o máximo que eu posso. Ele aceita muito bem. Até que... Mas não tem tanto carinho, igual tinha antes. Não tem mais beijo. É uma coisa mais fria. Mas eu faço mais p'ra ele sentir prazer. Agora nada. Antes vocês conversavam sobre tudo? Sobre o que vocês queriam, o que ele queria, se era legal, se não era legal. Me chamava de gostava, falava: eu quero assim, eu quero assado. "Vamos num motel?" Queria ficar seis horas "Vamos tomar uma cerveja?" nos barzinhos, era tudo diferente, "Vamos para Santos esta semana?" "Vamos dar um passeio?" A gente não tem dinheiro, não tem problema, a gente só vai passear um pouquinho na praia e voltar (Denise, mulher branca, ensino fundamental, não está usando nada como método).

Alguns tabus, em torno de algumas práticas sexuais, cercam 0 discurso de algumas mulheres. 0 mais freqüente é relativo à pratica sexual anal. PINHO et al (2002) verificaram que, entre os jovens, há uma diferença racial na prática do sexo anal. Jovens negros não expressaram gostar dessa prática, enquanto jovens brancos, sim. Trata-se de um assunto, que é abordado por nossas entrevistadas, como algo que perpassa a relação sexual. Sem dúvida nenhuma, o sexo anal é cercado de mitos e refere-se a uma forma de copulação, não procriativa. As duas mulheres, que explicitaram com mais clareza essa questão, são aqui apresentadas:

Marta, mulher negra, que usa o coito interrompido como método contraceptivo, fala de sua experiência sexual com seu parceiro, que exclui o sexo anal, por ambos não gostarem dessa prática. Ela refere que tal prática é desejada por todos os homens, mas que seu parceiro não gosta, por 
razões sanitárias. Revela, no discurso, uma aura de proteção do seu parceiro em relação a ela, o que nos leva a pensar que o homem, no caso desta relação, exerça um certo cuidado com a parceira. A fala, no entanto, é provocativa para pensarmos a forma de relação sexual desejada, que é a relação vaginal. Certas partes do corpo, no caso, a região anal, é investida de adjetivos que, pela negação, deduz-se como sendo suja e pouco adequada ao sexo. 0 discurso sugere que a erotização dessa parte do corpo é negada, pela sua inadequação à penetração e, possivelmente, à procriação.

[Agora eu vou passar p'ra umas perguntas que são mais íntimas. Então, como que é a vida sexual com seu marido?] É boa... é muito boa... eu... namorei muito... tive muitos namorados antes de conhecer o meu marido... e... e com ele, ele é mais assim do tipo... mais... é... como eu posso dizer... paciente... paciente comigo, porque... na questão sexual, não é? ... é... eu tenho aquela... aquela coisa de demorar, não é?... e... e ele já tem o lado de ser... mais demorado também, então isso bateu direitinho, a gente... eu acabei me entendendo com ele... aí, não é?... então, eu posso ficar tranqüila, não preciso ficar com aquela preocupação... aquele medo de estar cansando... então, é boa... nesse sentido... Você tem liberdade com ele... de falar? Muita liberdade de falar, de pedir... muita, mesmo... muita não, toda a liberdade... de falar o que eu quiser, de pedir o que eu quiser... entendeu?... ele me dá essa liberdade... E dele p'ra você também... Dele p'ra mim também... tem... e... mas eu sinto que ele me poupa muito, assim, ele quer que eu tenha as prioridades... Se preocupa com saber se você está tendo prazer mesmo? É isso? Exatamente. Isso... muito mesmo... se preocupa bastante...[Você e seu marido conversam normalmente sobre sexo?] Normalmente.. [Que tipo de papo....Que tipo de papo?] É... Sobre... tudo... conversamos sobre... por exemplo... o sexo anal, não é?... então, ele nunca procurou e eu achava que era por me poupar, porque ele tem 
um jeito, assim, de querer me... me... me proteger... aí, eu achava que era por isso... e... me incomodava, me incomodava, não porque eu queria, mas porque... eu acho que uma pessoa não tem que ficar protegendo demais a outra, porque... eu tenho o seguinte pensamento de que, na hora que enjoar, eu não estou nem sabendo... eu ia pensar "poxa, eu nem sabia que queria e que gostava", então, aí eu toquei nesse assunto: "porque que você nunca procura?... porque, pelo que eu sei, que a maioria dos homens... procura, e você, não..." , aí foi onde ele perguntou "porque, você gostaria?", aí, eu falei "não, mas eu fico preocupada.... porque, se você me procurar, apesar de eu não... não... de não aceitar, mas a gente ia conversar a respeito..." Aí, eu coloquei assim p'ra sentir se ele mudaria de idéia ou não: "e quem sabe, com você, eu, podia ser que eu...", p'ra sentir o lado dele, p'ra também não deixar que ele, com a minha resposta de que não, ele também se retraísse e ficasse na defensiva, então falei "quem sabe, com você podia ser diferente, você é meu marido", aí foi onde ele disse que não, que ele não concorda, que ele não acha certo e que ... ele falou também da questão da saúde da mulher e da saúde até dele mesmo, porque é um local que ele pode obter, sei lá, alguma infecção, alguma doença... e aí, eu... aí eu aceitei, cheguei à conclusão de que ele realmente não gosta, de que ele realmente não aprecia... A gente conversa sobre... sobre isso e sobre... é... tudo mais, sobre posições... e... sobre... problema de doenças... que podem ser adquiridas na falta, até na falta de higiene... Sobre tudo (Marta, mulher negra, ensino superior, coito interrompido).

Para J oana, mulher branca, de ensino médio, usuária de camisinha, todas as práticas e posições são negociadas com o parceiro. Seu discurso dá a entender que tudo é dialogado e conversado, até que se firme o acordo desejado. Nesse contexto, também, está excluída a prática anal, por ser 
dolorosa, e por isso, não the proporcionar prazer. Diferente dos tabus e conceitos sobre o que cerca o sexo anal, a entrevistada explicita que seu desejo é orientado pelo prazer sem dor e o sexo, como brincadeira.

[Está dentro do casamento de vocês, em relação às práticas sexuais, existe alguma negociação entre o que você quer e o que ele quer, fica claro, não fica claro?] Sim, fica, fica claro e às vezes há discussão, por exemplo, quando eu quero e ele não quer, ou quando ele quer e eu não quero, há um acordo já, eu uso essa palavra acordo, mas na verdade eu acho que é uma conversa, a palavra mais adequada, há muitos anos, quando a gente ainda namorava, que eu nunca transaria com ele se eu não quisesse, eu não iria transar com ele, nem porque eu era namorada dele, nem porque era esposa dele, se um dia fosse, e isso continua até hoje. E há uma conversa muito grande sobre a questão do gozo, o que é isso para cada um, o que significa a percepção do gozo no parceiro, não só o gozo físico, mas o gozo mental, a necessidade, nem sempre, de gozar da maneira que se propõe que é o gozo físico ou nem o gozo mental, às vezes transar por uma brincadeira, então assim, eu acho interessante que a gente conversa muito sobre essa, tirar esse peso da relação sexual dentro de um casamento. Nós mantemos a relação sexual como uma coisa importante e também uma brincadeira possível, se nós quisermos brincar, vamos brincar Sua vida sexual é prazerosa... Muito prazerosa, muito e na medida em que incomoda é imediatamente falado. Mesmo que eu saiba que isso possa trazer alguma discussão. [Você sente, você tem liberdade sexual com seu marido p'ra propor o que você quiser, ele propor o que ele quer?] Sim, sinto e ele tem, se ele propõe, eu não sei. Eu sinto que propõe, pelo tanto que fala, mas sabe que tem, porque da maneira como eu falo sobre o assunto, ele acaba falando, eu percebo que isso foi crescendo, do namoro até 0 casamento isso foi crescendo muito,, eu não senti que estagnou com os anos de casamento, não, nem a qualidade de sexo, de .. de 
transa, eu não perdi qualidade, porque eu não consigo manter um relacionamento se não for dessa maneira. Já não conseguia antes. [Tem pontos de conflito?] Tem, tem. Prática anal não é um ponto de conflito sério, mas é uma questão que, de vez em quando, é levantada, engraçado, por mim, não é por ele. Há uma questão que é essa questão que é a extra conjugal, não é nem dentro do casamento, mas é um ponto de conflito, ao mesmo tempo que eu acho que aceito, mesmo porque não aconteceu, mas eu imagino que sim, ele não aceita, mas não se dispõe a contar, eu digo, problema teu, então se resolva contigo. Porque, dizer não, eu acho um problema muito mais sério. Você não pode, por isto é que há essa inibição, eu tento fazer com que ela não aconteça, da maneira que eu falo p'ra ele não se posicionar, então fique quieto, se você acha que não pode ser desta maneira, não diga como deve ser, então vamos sentar p'ra conversar, mas não diga p'ra mim, deve ser de tal maneira. Na cama, a gente, na verdade, negocia muito o que vai fazer, de que maneira vai fazer, se vamos...[A relação anal, por exemplo, não é uma coisa que role bem, você disse...?] Na verdade, não é que não role bem, ela não rola. É assim, eu não, eu não curto esse tipo de sexo, ele me incomoda. O sexo oral não, tranqüilo, mas, por exemplo, eu sou orientada p'ra a maneira como eu devo fazer, que ele tenha o prazer, e eu acho muito legal, por que acho que é p'ra dar prazer e não p'ra provocar dor. E nós conversamos muito sobre como nós fazer, se seu quiser, por exemplo, vamos hoje brincar com a minha fantasia sexual. [Ah, qual, como pode ser?] Podemos brincar de tal maneira, mas nunca envolvendo dor, que p'ra mim é um problema sério, eu não suporto a dor dentro de uma relação sexual. E isto é um consenso. Então, na verdade, não há um . nunca...Já há coisas meio préestabelecidas... Já, na cama, já e é muito tranqüilo. Eu diria que nosso conflito maior não é na cama, quase não há, p'ra falar a verdade, quase não há. [Tem alguma coisa que atrapalha sua relação, sua vida 
sexual? Por exemplo?] Não sei.. Sim, trabalhar muito e vir muito cansado na hora que eu quero, e se eu quero, eu quero, a não ser que ele diga que não quer por que ele não tem vontade, mas ter vontade, estar cansado, isto p'ra mim é um problema, por que eu fico pensando, poxa vida, não é um problema de não querer, é um problema de não conseguir, porque está cansado e isto p'ra mim é conflitante (Joana, mulher branca, ensino médio, camisinha masculina).

No que diz respeito à sexualidade, mais propriamente, ao sexo, algumas mulheres brancas manifestam uma disposição para o sexo, levandonos a pensar que, ainda que o tempo de trabalho fora de casa roube um tempo importante para o casal estar junto, a liberdade conquistada, seja no mercado de trabalho, seja nos trabalhos domésticos, propiciou às mulheres maior disposição para o sexo.

A minha vida sexual, ela é muito boa, é uma vida sexual bem agradável, eu acho que eu e a gente tem uma afinidade sexual muito grande, a gente se dá muito bem na cama, acho que a gente tem, acho que nós dois não temos... gente dá start um pro outro, acho que isso é legal, a gente troca muito. A vida sexual nossa, a gente troca, enfim, a gente ativa muito nossa vida sexual. A gente tem uma vida sexual freqüente, mesmo com nosso tempo maluco a gente consegue, a gente até brinca que isso é uma reenergização pro nosso, p'ra nossa loucura. A gente consegue ter uma vida sexual freqüente, mas a gente não se preocupa com a freqüência da nossa vida sexual, não tem uma agenda, a gente deixa rolar, deixa acontecer, como pode ser que tem época, no meio de um turbilhão, que a gente fica um tempo maior sem se relacionar sexualmente, mas acho que a gente tem uma, tem uma energia sexual bem presente, atração, a gente fala 
muito disso, a gente tem um cuidado com isso (Sonia, mulher branca, ensino superior, vasectomia).

Na leitura de GIDDENS (1993), a maior experiência sexual das mulheres está relacionada à maior autonomia que elas conquistaram nas últimas décadas. A crescente inserção das mulheres no mercado de trabalho e a modificação dos papéis sexuais têm, crescentemente, conferido maior liberdade para as mulheres.

No caso das mulheres entrevistadas, a questão de gênero, aparentemente, determina uma experiência de vida sexual e conjugal diversa para mulheres de diferentes escolaridades, levando-nos a pensar que a inserção da mulher no mercado de trabalho, estreitamente relacionada à sua formação profissional, proporciona maior autonomia a mulheres de nível superior, refletindo-se, ao menos em nível do discurso, na maior ou menor liberdade de experiência sexual. Entretanto, no âmbito da conjugalidade, as mulheres ainda têm uma perda considerável de autonomia, em razão de estarem sobrecarregadas de tarefas domésticas, que não conseguem dividir eqüitativamente com os parceiros. Aquelas mulheres, que conseguem equilibrar suas atividades de trabalho fora de casa com o trabalho dentro de casa, contam com profissionais que as auxiliam. Mas, mesmo assim, a tarefa de administração do lar fica, na maioria dos casos, por sua conta, o que gera, também, esforço e, principalmente, trabalho.

Mulheres negras, de ensino fundamental, relatam que dialogam muito pouco, sobre sexo, com seus parceiros. Essa falta de diálogo vai se refletir na dificuldade de assumir um método, no qual o parceiro deveria ter mais participação.

Nós só conversa de sexo, assim, quando ele acha que eu estou demorando, só isso(risos). [Aí vocês começam a conversar] É, você não acha que está demorando muito, não? Vamos supor. Ele fala: 
"Vai fazer uns quatro dias". Não sei o que. "Quatro dia, quatro dia foi esses dias, o que quê tem“. E só nessas horas (Pámela, mulher negra, ensino fundamental, laqueada).

Para desafiar alguns fantasmas da relação conjugal, como a infidelidade, Denise (mulher branca, ensino fundamental) recomenda que a mulher deve procurar romper com tabus e se comportar como uma prostituta na cama.

A rotina, ainda não quebraram esse tabu de rotina, e o homem é sem vergonha mesmo, deixa a mulher dentro de casa e procura outra fora. Procura mesmo. Não existe homem fiel. Hoje em dia não tem. E a culpada é a mulher, porque ela coloca uma rotina muito rigorosa, mesmo que ela não queria ela põe. Ela tem que ter tipo, mesmo que ela tem aquela coisa com ele, ela tem que ser uma prostituta, ela tem que carregar ele pela mão para fazer outras coisas junto. E assumir um pouco (Denise, mulher branca, ensino fundamental, não está usando nenhum método).

O discurso, no âmbito da sexualidade, revela a necessidade de ruptura com uma ética que separa a "mulher-da-casa" da "mulher-da-rua", conforme refere SARTI (1996), para o estabelecimento de um campo de batalhas, em que existe forte apelo para a superação do problema da infidelidade. É apregoado que a mulher-da-casa transforme-se na "outra" para garantir, assim, a fidelidade e a monogamia absoluta, argumento principal para a exclusão da camisinha, conforme pudemos discorrer em capítulo anterior.

O discurso das mulheres negras, de ensino médio, não se altera muito em relação àquelas de ensino fundamental. 0 diálogo sobre sexo e sobre a própria sexualidade é reduzido. A questão da infidelidade permanece 
como um fantasma, ameaçando a monogamia e a necessidade de a mulher manter-se à disposição do parceiro.

Ah, no geral, eu não tenho problemas. Não, eu... assim: sempre fui uma pessoa mais quieta e ele mais atirado, mas no fim... as coisas se encaixam. Tipo: com o tempo você vai até se desinibindo e vai acompanhando, porque eu acho muito importante também não só você ser a mulher da..., você tem que ser um pouco de tudo, porque se não... vai, a primeira que aparecer na esquina, ele vai correndo atrás. Então, eu sempre tive minha cabeça voltada p'ra isso. Eu acho assim, que uma mulher, a partir do momento que ela casa, ela quer um homem p'ra ela, ela tem que seguir os passos dele, não é? Tipo: não naquela "Não posso. Não quero", entendeu? Você tem que...seguir, porque se não você não seguir... (Maria Célia, mulher negra, ensino médio, laqueada).

Entre mulheres brancas, de ensino médio, o marido começa a figurar como um parceiro na superação de questões ligadas à sexualidade. Coisa que é mais incomum para mulheres do segmento anterior. A questão da parceria se coloca em termos de formas pelas quais se busca o prazer e até para superação de problemas temporários, ligados à experiência sexual, como, por exemplo, no caso de Gilmara (mulher branca, ensino médio, camisinha masculina)

Olha, eu já tive dificuldade, já passei por uma experiência terrível, que é a mulher ficar frígida... por causa do trabalho, muita dívida... a mulher é muito... a parte emocional, assim, ela... ela não agüenta...enquanto não estiver resolvido aquilo, ela não.... não adianta, ela não consegue, ela fica tipo com bloqueio psicológico. E é onde vem a... a frieza. Meu marido, ele... ele me ajudou muito, ele teve paciência... qualquer outro homem não teria tido paciência... teria saído com outra, entendeu? Mas não, ele me ajudou muito... e 
aí, hoje em dia... nosso casamento tá em dia. Graças a Deus, tá em dia... Gosto... a gente faz, assim, umas duas, três vezes por semana... e é assim, de concordância... é o que eu falo p'ra ele, eu gosto de... tudo bonitinho, não é?... toma um banhinho, vai lá, não é?, faz o que tem que fazer, fica conversando, não é? Depois vai e faz outras coisas. É bom, o meu relacionamento com ele é muito bom (Gilmara, mulher branca, ensino médio, camisinha masculina).

A questão da parceria sexual se coloca, mais claramente, entre mulheres de ensino superior, brancas e negras, e no setor da sexualidade ocorre maior cumplicidade. Não há uma dicotomia entre a mulher-da-casa e a mulher-da-rua. Há, enfim, maior igualdade de gênero, que permite uma maior experimentação sexual, graças à maior autonomia das mulheres.

E assim nosso relacionamento vem de uma paixão muito forte, muito bonita, de uma coisa intensa, muito sexual, e assim a gente ficou junto assim, porque era demais. Não dava p'ra ficar sem. E era uma coisa física muito forte. E a gente foi acertando umas arestas, da subjetividade, da afetividade, porque eu estava me separando e tal. Mas não dava p'ra ficar sem ele, e ele não dava para ficar sem mim. A gente vai transar hoje e vai ser a ultima vez, amanhã a gente vai transar só hoje e vai ser a última vez. E assim foi indo e a gente foi ficando (J uçara, mulher branca, ensino superior, camisinha masculina).

Embora se perceba uma melhoria no âmbito das relações de gênero, quanto maior a escolaridade, o racismo coloca as mulheres negras em desvantagem neste quesito. A escolaridade impacta a vida das mulheres negras, somente no nível de escolaridade superior, quando elas passam a ter maior autonomia. Nos níveis médios e fundamentais elas vivem uma conjugalidade mais tradicional. Ao contrário das mulheres brancas, de nível 
médio que, em nível de discurso, equipararam-se às mulheres brancas, de nível superior. 0 enfrentamento do racismo, caracterizado no capítulo 10, é 0 que diferencia o cotidiano de mulheres, com maior prejuízo para mulheres negras, de modo que não se pode falar de igualdade de gênero, nos mesmos termos, para os dois segmentos de cor.

Em síntese, mulheres negras, de ensino fundamental e médio, como as mulheres brancas de ensino fundamental, discursam sobre a existência de uma conjugalidade mais tradicional, enquanto mulheres brancas, de ensino médio, e mulheres negras e brancas, de ensino superior, discursam sobre uma conjugalidade mais moderna, em que a parceria e a cumplicidade sexual são mais percebidas. Esta diferença aponta para o impacto do racismo na vida cotidiana das mulheres negras, que têm menos possibilidades de exercer a autonomia na vida conjugal, só conquistando isso nos patamares de escolaridade superior, quando têm uma possibilidade diferenciada de inserção no mercado de trabalho e acesso a bens e serviços, além da autonomia individual e ampliação do exercício da liberdade. Ainda assim, nesse caso, relatam situações de racismo de que foram vítimas. 


\section{O DISCURSO SOBRE A DISCRIMINAÇÃO DE GÊNERO E RAÇA}

No Brasil, a década de 70 deu visibilidade, entre tantos outros fenômenos, ao questionamento da democracia racial, com a denúncia do racismo, e da cordialidade e amorosidade dos brasileiros, com a denúncia de casos de violência contra a mulher. Esse período, segundo BARSTED (1994), caracterizou-se por revelar comportamentos intolerantes e assimétricos, portanto, discriminatórios. Ao mesmo tempo, tais questionamentos introduziram duas categorias importantes no pensamento sobre a formação social brasileira - gênero e cor.

De acordo com SAFFIOTI (1987), a discriminação de gênero e de raça é resultante de um sistema de dominação-exploração, fundado no patriarcalismo-racismo-capitalismo. Dessa perspectiva, o poder está nas mãos do homem branco rico, podendo a mulher branca rica usufruir desse poder, bem como, em seguida, na escala, o homem negro rico e a mulher negra rica, bem abaixo. $\mathrm{Na}$ base da pirâmide estaria a mulher negra pobre. A mulher branca pobre também seria discriminada, mas contaria com 0 privilegio da cor, que a mulher negra não possui. Nesse sentido, os poderes são distribuídos socialmente, de forma desigual e hierarquizada. As iniqüidades sociais, de acordo com essa visão, são parte de um sistema que ordena as relações sociais, fazem parte de uma totalidade. Como aponta SAFFIOTI (1995), o mesmo sujeito possui várias identidades (de gênero,raça/etnia e de classe). Trata-se de verificar qual identidade social será predominante, num determinado momento.

Discriminação de gênero

O fenômeno da discriminação de gênero é uma forma de recolocar a mulher em um lugar de ausência de liberdade. Como um mecanismo social, que encapsula uma determinada ordem social, a discriminação de gênero 
pode ser amplamente detectada, como forma de naturalizar diferenças entre homens e mulheres, ao mesmo tempo em que desloca, para o campo da natureza, desigualdades culturalmente estabelecidas.

Há, também, a idéia de uma dominação masculina, não meramente calcada no poder econômico, mas no poder simbólico. BOURDIEU (1996) assevera que a dominação masculina faz parte de um sistema que institui uma ordem social. E é, do ponto de vista da simbologia, que o homem ocupa o lugar do poder e o espaço público, enquanto as mulheres ocupam o espaço privado, a casa, e são a ele submissas.

Ainda que esta realidade esteja sendo gradativamente transformada, é possível afirmar que as mulheres tiveram, historicamente, sua identidade construída na heteronomia, dependente do outro, e na complementaridade ao homem. Nesse sentido, a discriminação de gênero ocorre para recolocar a mulher no espaço da ausência de liberdade e na heteronomia (CHAUÍ 1985).

O fato de a gravidez ocorrer no corpo da mulher é um dado biológico, passível de transformação, em função das tecnologias reprodutivas, que legitimam formas de opressão à mulher. Como apontam Del PRIORI (1989) e RAGO (1987), a forma de regular o direito à herança era ter uma prole legítima. Esse mecanismo fez do corpo da mulher um campo de dominação masculina.

A discriminação é uma temática que está presente no discurso de mulheres negras e brancas. No caso da discriminação de gênero, mulheres negras e brancas relatam que convivem com a mesma. Uma delas, a destacar, é a discriminação de gênero, que obriga mulheres a terem maior sobrecarga de trabalho do que os homens. Fica clara, no depoimento de Juçara, a dupla jornada de trabalho, por exemplo.

[E você acha que as mulheres são discriminadas ou não?] Eu acho que são, pelo o que eu falei já. A palavra da mulher não vale a mesma coisa. E se a mulher quiser trabalhar, maravilha, 
desde que... Hoje mesmo a gente... eu fui ver um apartamento, eu estou procurando, saí com uma corretora bem cedo. Aí, quando ela entrou no carro, ela falou: "Ah levantamos cedo" Aí, eu falei: "A gente levanta esse horário todo dia" Ela falou "Eu levanto 5 horas" Não sei se é verdade o que ela falou. "Eu levanto 5 horas, porque antes de eu sair, minha, deixo a casa toda arrumada" É muito triste, está louco. Você pode trabalhar, desde que você levante 5 horas e arrume sua casa. 0 que quer dizer isso, senão é discriminação? E fora que, enfim, a gente trabalha com os dados, eu sou socióloga, eu trabalho com os dados, eu sei. As mulheres, realmente todos os indicadores, todas as mulheres, principalmente das mulheres pobres, e principalmente das negras, são os piores. Não dá para desconhecer. Os dados aí do IBGE, não sou eu que estou falando. Então, lógico que existe discriminação (J uçara, mulher branca, ensino superior, camisinha masculina).

$\mathrm{Na}$ fala, abaixo, a mulher negra também relata, não somente a discriminação de gênero que está presente no cotidiano das mulheres, mas também o controle da sexualidade exercido pelos homens. Esse controle visa a não só manter as mulheres no espaço privado, como também, manter cerceada a sua liberdade, na vida pública.

[Há discriminação contra a mulher]Ah, ainda há um pouco sim, a gente fala que tem liberdade sexual, mas se a menina sai com vários rapazes, ainda tem aquela coisa de ser a galinha, de ser arrombada, que muitas pessoas falam e que eu acho horrível. Na periferia, tem isso. Se você vai para um bar, as pessoas te criticam "Ah, está parecendo homem no bar" Você percebe que os bares são ainda espaços... principalmente na periferia, são espaços masculinos. A gente que chega lá e 
rompe, às vezes, chega duas mulheres, mas o dono do bar logo já pergunta "Cadê o seu marido?" Diz alguma coisa, não fala nada, mas nas entrelinhas a gente sabe que ele quer dizer "Cadê o seu marido, o que você está fazendo aqui sozinha no espaço que é dominado pelo homem, que é o bar? (Hortênsia, mulher negra, ensino superior, laqueadura).

Um balanço da desigualdade, segundo BARSTED (1994), dá visibilidade a uma meta não alcançada, ou não formulada pelo ideário moderno, que é eliminar as assimetrias entre os sexos e a desigualdade de raça. A violência advinda dessas desigualdades revela a gravidade que alcança esse tipo de questão. Segundo a autora, até muito recentemente, a violência contra a mulher era considerada um assunto privado. A existência de espaços diferenciados e desvalorizados para as mulheres define padrões morais distintos, justificando discriminações.

De acordo com o autor, o ideal igualitário, típico da modernidade, foi incorporado, em certa medida, pela legislação brasileira, mas, sua prática cotidiana é muito frágil, possibilitando a coexistência de duas ordens, uma legal e outra prática. Isso pode ser detectado pela crescente, mas ainda pequena participação política das mulheres na vida pública. Além de se constatar, no mercado de trabalho, a discriminação salarial das mulheres e práticas abusivas, como a revista íntima, nas relações de trabalho.

Percebe-se que a discriminação de gênero impossibilita a construção de identidades autônomas e livres. A mulher vê-se, cotidianamente, cerceada e impossibilitada de autodeterminação. A dominação masculina se expressa em formas de opressão, que caracterizam a discriminação de gênero e, até mesmo, a violência de gênero. Como aponta BOURDIEU (1996), a dominação masculina é exercida através de um poder simbólico, que o legitima. Este fenômeno atinge mulheres negras e brancas, indistintamente, mas constatamos, entre nossas entrevistadas, que a mulher branca relata 
maior autonomia, pelo menos econômica, o que faz com que ela tenha maior capacidade de autodeterminação, em relação à mulher negra.

Não é possível negar a dimensão de gênero da discriminação racial, para a qual Mary ROBINSON (2001) chama atenção. Essa face da discriminação acomete mulheres de grupos racialmente em desvantagem, em vários campos. No campo da saúde, por exemplo, a autora aponta que mulheres de grupos, racialmente em desvantagem, apresentam altos índices de infecção pelo HIV/Aids, são socialmente estigmatizadas por isso, são forçadas à esterilização e a um coercitivo controle de natalidade.

Discriminação de raça

A questão da classificação por cor é um primeiro obstáculo que deve ser enfrentado para entendimento da questão racial no Brasil. Neste sentido, é interessante observar como ela se dá em nosso cotidiano. Encontramos, na literatura, o ponto de partida para a reflexão sobre a questão racial.

Em uma impressionante história sobre a guerra, denominada "O Prisioneiro", Érico VERÍSSIMO (1995) narra sobre um americano que conflita com sua origem negra e fala da sua dificuldade em lidar com a sua condição, num país em que, ser negro é ser vítima de um tipo de racismo que passa pela sua condição genética, escorre pelo sangue. Ele diz que seria branco em qualquer país da América Latina, enquanto em seu país, o fato de ser filho de pai negro faz dele um negro, mesmo que a mãe seja branca. Descreve os dramas e violências raciais que seu pai sofrera e da sua covardia em enfrentar tal situação, o que o fez optar por ir para a guerra, em que seu país vende a idéia de democracia, ao invés de ficar em seu país e lutar pelos direitos do homem de cor.

Esse drama, bastante atual, descreve duas situações de preconceito que foram tipificadas por Oracy NOGUEIRA (1985). Segundo este autor, as modalidades de preconceito estão intimamente relacionadas ao ethos social, 
ou seja, ao modo de ser culturalmente condicionado que "se manifesta nas relações inter-individuais, tanto através da etiqueta, como de padrões menos explícitos de tratamento"(NOGUEIRA 1985: 91)

A tipificação construída pelo autor exibe distinções entre as manifestações do preconceito nos E.U.A e no Brasil. Para ele, o preconceito pode ser tipificado como de marca, no caso do Brasil, e de origem, no caso dos E.U.A.

1. Quanto ao modo de atuar:

- o preconceito de marca determina uma preterição

- o preconceito de origem, uma exclusão incondicional dos membros do grupo atingido, em relação a situações ou recursos, pelos quais venham a competir com os membros do grupo discriminador

2. Quanto à definição de membro do grupo discriminador e do grupo discriminado:

- onde o preconceito é de marca, serve de critério do fenótipo ou a aparência, e qualquer que seja a proporção de ascendência do grupo discriminado ou do grupo discriminador. Segundo o autor, "a concepção de branco e não branco varia, no Brasil, em função da mestiçagem, de indivíduo para indivíduo, de classe para classe, de região para região" (p.80)

- onde o preconceito é de origem, o branqueamento, por mais completo que seja, não implica incorporação pelo grupo branco

3.Quanto à carga afetiva:

- onde o preconceito é de marca, ele tende a ser mais intelectivo e estético

- onde é de origem, tende a ser mais emocional e mais integral, no que toca à atribuição de inferioridade de traços indesejáveis aos membros do grupo discriminado.

4. Quanto ao efeito nas relações interpessoais:

- onde o preconceito é de marca, as relações pessoais de amizade e admiração cruzam facilmente as fronteiras de marca (ou cor) 
- onde é de origem, as relações entre indivíduos do grupo discriminador e do grupo discriminado são severamente restringidas por tabus e sanções de caráter negativo

5. Quanto à ideologia:

- onde o preconceito é de marca, a ideologia é, ao mesmo tempo, assimilacionista e miscigenacionista

- onde é de origem, ela é segregacionista e racista

6. Quanto à distinção entre diferentes minorias:

- onde o preconceito é de marca, o dogma da cultura prevalece sobre 0 de raça. Onde o preconceito é de marca, as minorias menos endogâmicas e menos etnocêntricas são favorecidas;

- onde o preconceito é de origem, a raça prevalece e há maior tolerância para com as minorias mais endogâmicas e mais etnocêntricas.

7. Quanto à etiqueta:

- onde o preconceito é de marca, a etiqueta de relações inter-raciais põe ênfase no controle do comportamento de indivíduos do grupo discriminador, de modo a evitar a suscetibilidade ou humilhação de indivíduos do grupo discriminado

- onde o preconceito é de origem, a ênfase está no controle de comportamento de membros do grupo discriminado, de modo a conter a agressividade dos elementos do grupo discriminador

8. Quanto ao efeito sobre o grupo discriminado:

- onde o preconceito é de marca, a consciência da discriminação tende a ser intermitente;

- onde é de origem, tende a ser contínua, obsedante.

Com essa tipificação, NOGUEIRA (1995) pretende assinalar formas distintas de preconceito, que devem ser enfrentadas de modo, também, distinto. A manifestação do preconceito no Brasil, sendo de marca, implica uma forma de classificação racial bastante peculiar, pois 0 ideal de 
branqueamento está presente. Nesse sentido, a classificação racial, no Brasil, desvenda tramas de conceitos de nomeação, que remonta o mito da democracia racial (SCHWARCZ 1996; MUNANGA1996). A propósito disso, é que SCHWARCZ (1996) discute as 136 cores diferentes, para designação racial, que emergiram na PNAD (1976), e reafirma a presença do ideal de branqueamento em nossa cultura. De um certo modo, é possível dizer que os discursos sobre cor e raça, abandonados pela ciência, pertencem ao mundo do senso comum (MAGGIE 1996).

Ao discutir a questão da classificação racial, WOOD (1994) demonstrou, em sua pesquisa, dois tipos de classificação racial no Brasil, que se distinguiam pela forma de abordagem do entrevistado: uma,considerada censitária, por utilizar parâmetros de classificação racial estabelecida previamente; e, outra, considerada subjetiva, pela qual a população se classifica, por meio de nominações, sem um critério pré-estabelecido, em diferentes pesquisas do IBGE. Wood afirma, ainda, que a população nãobranca não se identifica com a nominação censitária "parda", o que foi revelado, também, em pesquisa conduzida pelo DataFolha (FOLHA DE S. PAULO, 25/06/1995), que constata uma característica da população brasileira considerar-se "morena". Dada a relativa flexibilidade e ambigüidade deste termo, a classificação e identidade negra submergem, em inúmeras considerações teóricas e conceituais, acerca da classificação racial e "mito da democracia racial".

O "mito da democracia racial brasileira" revelou-se uma armadilha discursiva, que trouxe subjacente a idéia de "branqueamento". Esta, considerada, também, um meio para a mobilidade social, tem na mestiçagem um elemento importante no processo de branqueamento de idéias e corpos, estruturas e conjunturas, que negam a origem africana de alguns segmentos da população brasileira. Por meio de um discurso de que não há discriminação, a sociedade brasileira lapidou, cuidadosamente, a identidade mestiça que contém, em si, a proposta de "branqueamento" da população. 
Estabeleceu, ao mesmo tempo, um processo de negação da identidade negra e de negação da idéia de que há racismo no Brasil. 0 "mito da democracia racial", construído sob os auspícios de concepções eugênicas, resulta em dilemas sociais, como a discriminação racial. Segundo MUNANGA (1998, 2002), SCHWARCZ (1998) e HASENBALG (1998), o racismo está enraizado nas relações sociais no Brasil.

A definição da cor, então, é estabelecida no campo de percepção, de acordo com o qual as pessoas podem ser colocadas no limite entre brancos e não-brancos, ou negros e não negros. Dado que esta categoria de classificação não tem limites estanques, e que o conceito de raça é construído no limite das relações sociais, e, portanto, definido no campo relacional, espaço de inúmeras disputas e hierarquias, trata-se de uma construção no âmbito das relações sociais, desvendando, assim, formas de exercício de poder e do próprio racismo, além de ser um dado do imaginário social. Desta forma, ser negro, no entender de COSTA (1985), é estar submetido a uma forma constante de violência, que configura "dupla injunção: a de encarnar o corpo e os ideais de Ego do sujeito branco e a de recusar a presença do corpo negro".

Sendo assim, o racismo, além de estar representado através de indicadores, tais como o Índice de Desenvolvimento Humano (IDH) (SANT'ANNA 2001), tem repercussões, inclusive, psicossociais, sobre os indivíduos.

10.10 reconhecimento do racismo

[Você acha que existe discriminação racial no nosso meio?] Muita, eu sei...dizem que isso é crime. Mas isso não acontece, não. Tem lugares que negros não podem entrar. Tem clubes que não aceitam negros. Quando era pequena, eu sei que um clube ali, que se chama Esperia, no Tiete. Ele não aceitava que entrasse gente morena. Eu não sei se 
hoje ainda é assim. Até uns 10 ou 20, 15 anos, era. (Suzana, mulher branca, ensino superior, camisinha masculina)

- racismo ainda continua muito forte... o racismo é mais forte aqui no Brasil, de que fora do Brasil, acredita? Os brasileiros são muito racistas (Sabrina, mulher negra, ensino fundamental, extraiu as trompas).

O discurso sobre o preconceito e a discriminação apresenta-se como algo que está presente na realidade das pessoas, pois vêem e percebem 0 racismo no cotidiano. Sendo o racismo um problema das relações raciais, no Brasil, envolto na aura do mito da democracia racial, é difícil de ser diagnosticado, o embranquecimento ideológico das pessoas negras, a vergonha leva, muitas vezes, as pessoas discriminadas a esconderem o fato. 0 racismo é definido como um constrangimento social. A sensação de indignação frente ao racismo é comum às interlocutoras, que vêem nele uma forma de ofensa à dignidade humana, como de fato é.

Se eu pudesse, eu falava para o mundo inteiro que a cor das pessoas não conta, o que conta é a alma da pessoa e, às vezes, se ofende uma pessoa num gesto, ou falando, você está ofendendo a alma dela.Tem que se tratar as pessoas com mais dignidade, porque ninguém tem culpa de nascer negro, branco, amarelo, vermelho. Ninguém tem culpa. A cor da pele não vale nada. O que vale é cada um. Às vezes, você coloca uma pessoa branca chique dentro da sua casa e ela não vale uma metade de uma pessoa simples, ou negra, ou pobre (Eliane, mulher negra, ensino fundamental, laqueadura associada à camisinha masculina). 
Diferentes mulheres entrevistadas, brancas e negras, vêem 0 racismo ser difundido no cotidiano de diferentes maneiras. É no transporte público, é no mercado de trabalho, é na escola, entre outros. 0 racismo está presente no cotidiano, fazendo com que pessoas de origem racial/étnica negra sejam identificadas através de imagens de inferioridade e de exclusão social. Há um consenso, entre mulheres brancas e negras, em relação à idéia de que o racismo atropela as vidas das pessoas, fazendo com que 0 cotidiano seja mais difícil para as aquelas de origem racial negra. 0 sentimento, de que o racismo não tem solução, aparece no discurso de algumas mulheres, que lamentam terem de enfrentar isso no seu cotidiano:

Sobre discriminação, a única coisa que eu tenho a dizer sobre a discriminação é que isso não vai acabar nunca (Pámela, mulher negra, ensino fundamental, laqueada).

Acho que a discriminação é da nossa sociedade. Existe e vai existir sempre, mas nós, negros, temos que aprender a ser melhor, achar que somos capazes como qualquer um e bola p'ra frente, e não deixar o preconceito derrubar a gente, não, tem que lutar e vencer (Ana, mulher negra, ensino médio, laqueada).

A constatação do racismo aparece, logo quando a pessoa sai de casa para trabalhar. Então, é comum algumas mulheres dizerem que percebem isso no transporte público, no ônibus e no metrô. Aonde o direito se estabelece, o racismo aparece, sendo o negro excluído do exercício desse direito.

\subsection{Constatação do racismo}

Além da discriminação de gênero, existe a discriminação de raça. Nesse sentido, a mulher negra é duplamente vitima da discriminação. 0 racismo não é auto-referido, mas identificado com o outro, no caso de 
mulheres brancas. Já no caso de mulheres negras, a questão é diferente. Os casos de racismo se apresentam como algo próximo, com elas mesmas, com alguém da família ou amigos.

Situações de constrangimento são constatadas por mulheres, em diferentes espaços sociais, tais como no mercado de trabalho, na escola e, até mesmo, no espaço de lazer. Segundo SANSONE (1996), que partiu da noção de habitus, para construir sua concepção de espaços sociais no Brasil, divididos como áreas duras (difíceis de inserção do negro) e áreas moles (maior inserção do negro), a questão racial é abordada, diferentemente, em cada uma dessas áreas. Entre as áreas duras, o mercado de trabalho, o mercado matrimonial, contatos com a polícia, dentre outros espaços, em que a inserção do negro é difícil e é problematizada. Já entre as áreas moles, o jogo de futebol, sambão, os espaços de lazer. Nesses espaços, a questão racial é desproblematizada. Manifestações do racismo, quase sempre, acontecem para constranger a(o) negra(o), e tais situações podem ser constatadas em diferentes circunstâncias do cotidiano. Uma resposta à situação de discriminação, nem sempre é possível e, por vezes, a pessoa sequer esboça uma reação ao ato de constrangimento, imobilizada que fica frente à discriminação.

Todas as mulheres negras, no presente estudo, com diferentes escolaridades, têm histórias de discriminação racial, que constataram em seu cotidiano, seja com ela ou com alguém da família ou amigo.

As situações de discriminação vêm, a principio, de uma aparência que não é eurocentrica, e localizam os mais pobres, os negros, como excluídos do poder de consumo e de status social.

Situação de discriminação no Shopping

... eu sei, porque já aconteceu isso com a minha filha. Já, situação que ela foi no shopping comprar uma roupa e só tinha loiras atendendo e não fizeram questão de atendê-la. Não fizeram questão, 
acho que por causa da cor, acharam que ela não tinha dinheiro. Aí, o que ela fez, ela foi na loja ao lado, comprou a roupa mais cara que tinha na outra, e voltou na mesma loja, só pra elas ver a sacola que ela estava carregando. Aí, quando viram, aí foram perguntar se ela queria alguma coisa (Pámela, mulher negra, ensino fundamental, laqueada).

O Shopping center é um espaço em que a exposição é uma constante. Nesse espaço de exposição, há uma dada qualificação das pessoas, em função de sua capacidade de consumo.

Nele, as pessoas negras costumam ser discriminadas, em função do que socialmente é dado como natural, sua exclusão social. Nesse espaço, é sacramentada, também, a discriminação do fenótipo negro, que é associado à pobreza.

Situação de discriminação no mercado de trabalho

Eu trabalhava há três anos num frigorífico e chegou uma loira pedindo emprego, muito bonitinha, mais nova do que eu. A minha experiência não valeu. Valeu a capacidade dela ter boa presença, boa aparência, mais alta e pela cor (Eliane, mulher negra, ensino fundamental, laqueadura associada à camisinha masculina).

Percebo que ele tem, por ser negro, ele tem que trabalhar o dobro, pra provar o seu valor o tempo todo. Então, eu acabo percebendo indiretamente o preconceito na minha vida com ele, por que socialmente o que acontece, ele como diretor artístico negro é um problema sério. Eu sinto que ele, todos os dias, tem que matar um leão no trabalho pra provar que é um bom guerreiro, e isso afeta nossa relação, porque ele chega em casa morto de cansaço, trabalha, 
em média, de 12 a 14 horas, em média, é muita coisa (Joana, mulher branca, ensino médio, camisinha masculina)

Eu sofri, já. Eu, quando era bem jovem, acabei... tinha acabado de sair de um curso de datilografia, na época, tinha terminado o colégio, fui fazer entrevistas, eu, com uma colega... branca, e ela tava no ginásio, ela conseguiu emprego, eu não. Eu já tinha terminado o colégio e tinha um curso de datilografia... Não sei se é por causa da idade também, que ela era mais jovem do que eu, mas... eu senti uma discriminação (Amanda, mulher negra, ensino médio, histerectomizada).

Eu não lembro com detalhes. A gente vê muito. A gente que lida com publico, então, você vê muito, "ah eu não gosto de nego". Inclusive, aconteceu de um paciente falar para mim "Eu não gosto que nego põe a mão em mim! Substitua estas enfermeiras" "Eu não quero enfermeira negra, eu quero enfermeira branca, se fosse na minha época, que eu era rico, você não limpava nem a minha cozinha." Isso já aconteceu comigo e com uma amiga minha. Mas a gente já aprendeu a superar essas coisas e acaba não ligando (Ana, mulher negra, ensino médio, laqueada).

0 mercado de trabalho é um campo de profundas desigualdades, e um espaço em que o padrão eurocêntrico regula a inserção em postos mais qualificados. Nesse campo, percebe-se a discriminação, tanto no acesso a uma vaga, como no cotidiano. Mulheres negras apresentam dificuldades para se manterem na posição conquistada, devido à discriminação. 
Situação de discriminação com a polícia

A polícia pegou o meu menino aqui no portão. Ele tava sentado com um colega dele... já faz três anos que aconteceu... eu tinha ido pro [...] Santa Luzia... eu cheguei, ele falou "Mãe, a polícia me pegou". E eu falei "Porque que a polícia te pegou?..."Mãe, eu tava simplesmente sentado aqui. O guarda mandou eu ficar com a mão p'ra cima, encostado e ele pôs a mão no meu... no meu pescoço... a arma... começou me revistar e mandou eu andar lá p'ra cima"... todos os vizinho aqui viu... que ele morava aqui.. . ninguém falou nada que ele morava aqui... ele pega e vai subir lá p'ra cima... eu falei "Coisa que você não devia de fazer era ter subido lá p’ra cima. Andar por aí."... porque.. isso é...é ou não é? Eu fiquei horrorizada... até... depois disso que aconteceu, eu não confio mais em nenhum polícia... não confio ( Regiane, mulher negra, ensino fundamental, laqueada).

O enfrentamento com a poíicia atinge fortemente os homens, mas impacta na vida das mulheres negras, em alguma medida. São seus filhos, maridos, irmãos, tios, pai, que são alvos fáceis da policia. Na perseguição a suspeito de supostos crimes, homens e meninos negros encabeçam a lista. De acordo com SANSONE (1996), esta é uma área dura para os negros.

\section{Discriminação da estética negra}

Ah, eu já ouvi falar assim, de... não querer casar porque os filhos vão sair com cabelo duro. Isso aí eu já... escutei bastante, por isso que eu falo que é o cabelo, a discriminação é mais no cabelo do que a cor... No meu, na minha opinião, eu acho que é isso. [Quer dizer, o... o cara, a mulher ou o cara branco, que se envolva com um negro, acaba tendo medo de ter...?] É, os filhos vão... vão nascer com o cabelo... ruim. Então, eu acho que... o maior racismo é no cabelo... 
mais do que na cor (Rosana, mulher negra, ensino fundamental, laqueada).

A imagem da mulher negra colide com a imagem de mulher-esposa, mãe dos filhos. No campo dos namoros e dos casamentos, a escolha tende a ser por um padrão mais branqueado. Como aponta SANSONE (1996), esta também é uma área dura para os negros, principalmente, para as mulheres negras, que têm pago um alto preço, com um número maior de mulheres celibatárias, a partir de uma certa idade, de acordo com BERQUÓ (1987)

\section{Discriminação no casamento exogâmico}

Eu tenho [...] comigo mesma. A família do meu marido me detesta, porque eu sou preta... E o meu sogro, que Deus o tenha, morreu porque não gosta[...] ... por causa da... não fala[...]... sem falar comigo, por causa da minha cor, e ele falou p'ra mim que não gostava de mim, porque eu era preta. Então, eu sofri uma coisa de racismo. Eu não processei ele, não fiz essas coisas, porque p'ra mim era baixaria e, segundo, ele era velho, tava gagá já. Eu não... não tava, não tinha, não queria ele, queria o filho dele, então... p'ra mim tanto fez, entendeu? Mas... eles falava... ele morreu falando que não gostava de mim, por causa da minha cor... Quando eu tava grávida do meu filho, ele falava que ia nascer um macaquinho preto, que não sei o que. Então, eu tive na pele... eu senti na pele o racismo. E até hoje, ainda, são... tanto que me chamam de nega, isso e aquilo outro, a família dele. Ninguém é muito chegado a mim por... ser preta... e olha que eu não sou tão, não é? Tem, diz que tem, o verdadeiro negro, que é aquele bem escuro, não é?, com os olhos vermelhos... imagina se eu fosse... então. Não tenho, eu que não tenho racismo por nenhuma... cor nenhuma. No entanto que, o meu primeiro namorado era... loiro do olho azul; já tive um negão daqueles dos olhos 
vermelhos, então, não tenho essa coisa... mas eu sofri, na pele, e foi muito dolorido p'ra mim, principalmente porque eu tava gestante do meu primeiro filho. Sofri p'ra caramba porque... não imaginava, não é?, entrar numa família e... passar por isso ( Sabrina, mulher negra, ensino fundamental, extraiu as trompas).

A prole branca faz parte de um ideário de branqueamento, que vigora na cultura brasileira, e é expresso nos trabalhos de OLIVEIRA VIANA (1991). A eugenia, expressa por esse pensador brasileiro, apontava, como única saída para o povo brasileiro, o embranquecimento da população brasileira. 0 enfrentamento dessa ideologia aparece, cotidianamente, na vida das mulheres negras.

\section{Discriminação no consultório médico}

Já no... na... quando... uma vez, que eu já tinha meu filho, eu fui levar ele num pediatra, aí a moça falou assim: "Ah, você é a babá dele?" E eu: "Não, sou mãe." E ela falou que não... que não era, que eu queria ser mãe dele, por que?... só porque ele era branco, eu queria ser mãe? Porque o meu menino era bem branquinho, e ela fal[...], ficou... teimou comigo que o filho não era meu. Aí, arranquei o registro da bolsa, RG e tudo, e enfiei na cara dela assim. Então, foi uma discriminação, não é?, Porque ela achou que eu estava mentindo (Sabrina, mulher negra, ensino fundamental, extraiu as trompas).

Os embates cotidianos com o racismo produzem algumas situações peculiares, como a referida pela entrevistada, acima, cujo filho nasceu branco em relação a ela. No Brasil, a criança é considerada branca, nos E.U.A ela seria negra, sem sombra de dúvida. Essas peculiaridades revelam como o conceito de raça é construído socialmente, e não dado biologicamente. 


\section{Discriminação no elevador}

Discriminação, acho que as pessoas não contam essas coisas. Só na televisão. Isso de elevador. Eu já me senti uma vez discriminada, foi uma coisa muito sutil. Eu ia sempre a um prédio onde fica o dentista e aí, um dia, tem uma coisa de se identificar na porta, tem muito isso. Aí, um dia, eu chego, tinham duas senhoras na minha frente, aí as duas entraram, falaram com o moço da portaria, falaram bom dia e passaram. Vamos no consultório tal e passaram. Aí, quando eu cheguei, eu falei bom dia e fui passando, também. Ele falou onde você vai. Eu respondi: vou no consultório tal. Aí, ele falou: vem aqui. Eu tive que mostrar meu documento, e ele colocou meu nome na lista. Mas aí, eu falei para ele, por que aquelas duas pessoas passaram antes e você não pediu o documento? Aí, ele ficou todo atrapalhado. Foi porque eram duas loiras e eu não sou loira. Ele ficou mais atrapalhado ainda. Acho que, nem para ele estava claro, a hora que eu falei, ele ficou meio assim, porque elas passaram "Vamos não sei aonde." E ele era negro também ( Regina, mulher negra, ensino superior, camisinha masculina).

O elevador social aparece como metáfora do ciclo de desvantagem, e como expressão do lugar que o negro ocupa em nossa sociedade. Aqui, em muitos casos, o negro incorporou a ideologia presente no meio social, para legitimar uma separação. A discriminação, no elevador, revela a incorporação ideológica do racismo, a serviço da discriminação.

A consciência de que atos de racismo fazem parte do nosso cotidiano, está presente em discursos, mas algumas mulheres revelam dificuldades em compreender que, algumas situações de constrangimento, que viveram, estão relacionadas ao racismo. Assim, discutir outras faces do racismo, como aquelas ligadas a questões estruturais, ou mesmo, à saúde, em nossa sociedade, é mais difícil, pois, quase sempre, ele é negado e 
assumido como um problema das relações interpessoais e descaracterizado como problema social.

O racismo, quando pensado como uma face das relações estruturais, em nossa sociedade se mistura ao problema da pobreza. Como aponta HASENBALG (1983), o negro enfrenta um "ciclo de desvantagens acumuladas", que o coloca entre os mais pobres dos pobres. Aqueles negros, que escaparam desse "ciclo de desvantagens" e conseguiram uma posição de destaque, também enfrentam, no seu cotidiano, o preconceito e a discriminação.

Quando se trata da saúde, algumas entrevistadas percebem que é possível ocorrer discriminação em algumas situações de atendimento, mesmo assim, ele é colocado como uma questão das relações interpessoais e como um problema de aparência. Trata-se do preconceito de marca, como referimos anteriormente.

Situação de preconceito no serviço público de saúde

Assim, aí vem uma mulher, não está bem arrumada, é assim, não está bem arrumada, ela é negra, às vezes, está até mesmo, assim, sujinha. Da p'ra ver a cara dos funcionários, o jeito de atender: um jeito mais seco, como se tivesse nojo. Agora, se é uma pessoa branca, já seria diferente ( Pámela, mulher negra, ensino fundamental, laqueada).

Segundo as entrevistadas, médicos, em algumas situações, não tocam a paciente, fato que a interlocutora relaciona ao preconceito racial.

[E você acha que o preconceito de cor tem alguma influência na saúde da mulher? Pode influenciar na saúde da mulher?] Pode. Pode influenciar muito.[Como, assim, você [...]?] Porque muitas... as vezes, que você... entra numa sala do médico... às vezes mesmo... que você vai entrar no médico, o médico só olha p'ra você assim, e não... de 
medo de encostar a mão em você, eles não encosta a mão... Certo? Todo mundo...[Então aí já...]. É... aí já... ele já... [Não atende..] [sinal de não] [ . ... direito a pessoa...] Não atende. Da minha parte, as vezes quando eu[..]...vou assim, eu... se bem que todos os médicos que eu vou sempre fala, explica... pede alguma explicação... mas tem outros que não gostam nem de por a mão em você... eles não gosta mesmo (Regiane, mulher negra, ensino fundamental, laqueada).

O constrangimento racial pode, em algumas situações, gerar o que a entrevistada chamou de "vergonha". Tal sentimento levaria a um maior abandono do corpo e dos cuidados necessários para uma boa saúde.

Não sei (risos)... eu tenho vergonha (risos)... Eu não sei. Eu falo assim... é... por ser negra, talvez... ela já... viva, não é?, viva muitos preconceitos, que as pessoas fazem a ela, não é?, viver aquilo, talvez ela tenha medo de... vergonha de muitas coisa se, talvez ela se afaste de se cuidar... pode ser... assim que eu to falando .... eu to falando que pode ser que seja assim. Que tenha vergonha de procurar... cuidados médicos, muitas coisas, por vergonha. Talvez ela esteja vivendo algum tipo de preconceito ( Marina, mulher negra, ensino médio, não está usando nenhum método).

Situações, em que o racismo pode influenciar a saúde da mulher, é pensada como psicológica, como um problema das inter-relações sociais, com reflexos para a saúde mental.

No psicológico, acho que mexe muito. Quando você é agredida no teu eu, mexe sim. Mexe com a saúde (Ana, mulher negra, ensino médio, laqueada). 
Porque, se você passa por uma situação de preconceito, é uma pressão social e isso vai ter uma conseqüência no seu corpo, também. Acho que, tudo que acontece socialmente, pode ter uma conseqüência, também. Saúde mental, psicológica, as vezes, você fica muito tímido, porque sofre preconceito, depois, você supera isso, mas tem uma fase que você acaba passando por isso (Hortênsia, mulher negra, ensino superior, laqueada).

Grande parte das entrevistadas não percebe que, na situação de atendimento, ou na própria invisibilidade da questão racial, no âmbito da saúde, reside o problema da exclusão racial/étnica. Por outro lado, a concepção de corpo saudável, igual para qualquer Ser Humano, esconde as desigualdades raciais, a que os negros estão submetidos.

Eu acho que não. Isso aí, eu acho que não. Porque a saúde não tem cor, não tem... A saúde do Ser Humano não tem cor, não tem... nada... é transparente, quando tem que ser, não tem classe social, não tem cor, não tem... A saúde... p'ra todos, não é ?; p'ra todas as... Aí já... a saúde é uma coisa que... a gente... quem é saudável tem que agradecer todo dia a Deus. Não importa se você é branco, preto... se você tem dinheiro, se você não tem... porque a saúde só Aquele lá que pode Ihe dar; se Ele tirar, já era. Você pode ser branco, preto, vermelho, azul (Sabrina, mulher negra, ensino fundamental, extraiu as trompas).

A percepção, de que o racismo pode impactar a saúde da mulher, conflita com a idéia de que somos universalmente iguais. A diferença, baseada na raça, não existiria, e o racismo, apesar de afetar o psicológico, não produziria doenças de outras naturezas e é, nesse sentido, que a percepção do racismo situa-se no conjunto dos problemas sociais, como 
questões externas e sem impacto no interno, que afetaria a saúde do corpo. Essa exterioridade da questão racial limita-a à esfera da aparência.

A saúde é compreendida como um dom divino, concedido por Deus e, como Ele nos fez à sua imagem e semelhança, somos perfeitos frente a Ele. Doenças produzidas pela pobreza, e aquelas, de origem racial ou de gênero, não são entendidas, como passíveis de serem corporificadas, ou seja, pela possibilidade de produzirem impacto na saúde. A busca por uma visão corporificada das questões raciais confronta-se diretamente com aquela visão que, em maior ou menor grau, está presente no discurso das mulheres.

Entretanto, a partir do trabalho de BATISTA (2002), há a possibilidade de se refletir sobre o processo saúde doença e compreender que 0 racismo causa danos à saúde e pode, inclusive, ser a causa da maior mortalidade da população negra, por algumas doenças. BATISTA (2002:14), apoiado em Bourdieu, afirma que a população negra está "em um determinado espaço social: de menor capital econômico, menor capital cultural e menor capital global". Isto, com certeza, tem repercussões na saúde das mulheres negras.

O "direito a ter direito" (TELLES 1999) exige o reconhecimento dos sujeitos de direito, e isso, nem sempre, é possível em uma sociedade que mantém, como ideologia, o "mito da democracia racial", responsável, ao mesmo tempo, pela indefinição de cor. Mas, para OTTMANN (1995), "reconhecer" está no campo da consciência e requer um ato de nomeação, dentro de um contexto, que oferece ao termo o significado ou a atribuição de uma identidade; tais termos, ou identidades atribuídas, são orientados por virtuais nomeações e julgamentos, que devem ser baseados em um consenso, costume e acordo social, por meio da (e na) linguagem. 
Para Boaventura de Sousa Santos,

"as pessoas e os grupos sociais têm o direito a serem iguais, quando a diferença os inferioriza, e o direito de serem diferentes, quando a igualdade os descaracteriza" (SANTOS 2000: 37).

O racismo, segundo um dicionário de filosofia (ROSENTAL e RUDIN, 1959), é definido como uma teoria reacionária, que se apoia na tese da desigualdade original dos homens e pretende que a história da sociedade e da cultura humana obedeça a leis biológicas, imutáveis e eternas.

Nesse mesmo dicionário, raça é definida, enquanto agrupamentos biológicos de homens, constituídos em um período muito antigo da evolução da humanidade. As raças se distinguem pela cor da pele, os traços do rosto, a conformação do corpo, a forma e a cor dos cabelos. Assim, os caracteres distintos da raça negra são: pele escura e cabelos crepos; da raça amarela (chineses, japoneses, mongóis, buriatos e outros), pele amarelada, cabelos lisos e negros; da raça brança, pele de cor clara. As raças, segundo o verbete, formaram-se devido à influência das condições naturais, do isolamento do homem primitivo e da ausência de comunicações desenvolvidas entre eles. As distinções raciais não são mais que um fator secundário, ao lado do fator principal, incontestavelmente, estabelecido pela ciência: a unidade biológica da humanidade ".

O discurso anti-racista, presente nesse verbete, está marcado pelo processo histórico, pelo qual o mundo passava no pós-segunda guerra, e traz uma concepção de raça universal: a raça humana. Segundo SARTRE (1970:7), refletindo sobre a questão judaica, o racismo está assentado em um ódio que, por sua vez, está assentado em uma lógica passional. A repugnância que o racista tem "é um compromisso da alma, mas tão profundo e tão completo, que se estende ao fisiológico, como sucede na histeria". O racista, por sua vez, é fruto das multidões, identifica-se com um rebanho, e teme a sua diferenciação, por medo de toda espécie de solidão, 
tem medo de defrontar-se com sua própria figura. Ao mesmo tempo em que engendra, no outro (judeus, negros, índios, etc), esteriótipos que justificam o seu ódio. É um sentimento irracional.

Embora determinadas concepções de raça tenham sido muito importantes para as doutrinas racistas, SARTRE (1970:25) conta-nos que " as explicações pela hereditariedade e pela raça aparecem mais tarde: são como o tênue revestimento científico desta convicção primitiva; muito antes de Mendel e Gobineau, existia o horror ao judeu e os que experimentavam não poderiam explicá-lo".

0 racismo atingiu, e atinge, diferentes populações no mundo, então, como pensar, por exemplo, o mestiço? Este se tornou um personagem "fora do lugar", uma "fórmula de salvação"? O que dizer da nossa realidade nacional?

As discussões teóricas, produzidas por Oliveira Viana e Nina Rodrigues, fazem a reconstituição de como os intelectuais brasileiros pensavam a nossa realidade. A crença de Gilberto Freire na democracia racial, arsenal ideológico das classes dominantes da época, mostrava-nos um país, sem distinção de cor. 0 processo de embranquecimento da nossa população foi a fórmula encontrada para "resolver" o nosso problema de raça.

Se, no pós-segunda guerra, tratava-se, por exemplo, de romper com uma idéia básica, de que existiam diferenças biológicas entre os seres humanos, que indicavam uma hierarquia da natureza e, assim, que alguns grupos eram mais capacitados que outros, na década de 80, percebeu-se que a certeza da unidade da raça humana não era suficiente. As desigualdades sociais, impostas historicamente, impactavam, e impactam, a vida das populações de cor, no Brasil. Instalaram-se diferentes perspectivas de luta pelos direitos das populações discriminadas. Desigualdade sociais, construídas em um processo histórico de dominação, foram realocadas a um 
espaço de diferenças "naturais", em um processo de naturalização das diferenças, socialmente construídas. Mas como identificar as manifestações do racismo, à moda brasileira?

Para saber o que é racismo, à moda brasileira, Rufino Dos SANTOS (1984) nos dá uma receita: basta prestar atenção aos jogos de sentidos, presentes nas frases do nosso cotidiano, aquelas velhas e cansadas frases: "Preto, quando não suja na entrada, suja na saída", ou atentar para práticas, como proibir empregadas domésticas de utilizarem o mesmo elevador que a patroa, ou pedir uma secretária de "boa aparência", com o intuito de eliminar moças negras da concorrência, como se, ser negro, e não ter "boa aparência", fôssem sinônimos ou, ainda, "preto parado é suspeito, correndo, é ladrão".

Dizer que, no Brasil, o preconceito racial pode ser caracterizado como preconceito de marca (NOGUEIRA 1985), significa, pois, que a visibilidade da cor é que faz do negro uma vitima da discriminação. Neste sentido, ser negro, no Brasil, é passar por uma série de humilhações, que ofendem a dignidade humana. A experiência de ser negro, no entanto, para além da discriminação, requer um processo de conscientização e politização da questão, requer uma desnaturalização e compreensão dos processos históricos de construção desse sujeito. Assim é que, em nossa sociedade, 0 mito da democracia racial escamoteia a realidade, ao afirmar existir uma igualdade, que não existe de fato. 0 mito, segundo SOUZA (1983:25), é "um conjunto de representações, que expressa e oculta uma ordem de produção de bens de dominação e doutrinação". Nesse sentido, o mito da democracia racial oculta a opressão cotidiana, sob a qual vivem os negros, fazendo com que não tenham argumentos para a construção de um discurso de resistência proferido diariamente.

A negritude, como forma de consciência, permite ao negro lutar contra a alienação e contra a inferioridade imposta nas relações sociais. 
Assim é, que, nas palavras de MUNANGA (1990:111), "o negro se dá conta de que a sua salvação não está na busca da assimilação do branco, mas sim na retomada de si, isto é, na sua afirmação cultural, moral, física e intelectual, na crença de que ele é sujeito de uma história e de uma civilização que the foram negadas e que precisava recuperar. A essa retomada, a essa afirmação dos valores da civilização do mundo negro deuse o nome de "negritude". Explicações economicistas concorrem contra esta vertente, de retomada da identidade negra. Ainda, segundo MUNANGA (1990:116), "Os que pensam que a situação do negro, no Brasil, é apenas uma questão econômica, e não racista, não fazem um esforço para entenderem como as práticas racistas impedem, ao negro, o acesso na participação econômica. Ao separar "raça" e "classe, numa sociedade capitalista, eles cometem um erro metodológico, que dificulta a sua análise, e os condena ao beco sem saída de uma explicação puramente economicista". Nesse sentido, a cidadania do(a) negro(a) está intimamente relacionada a uma consciência de negritude, que se faz presente, à medida que negro(a) coloca-se reflexivamente na sociedade, repudiando a ideologia de branqueamento que o(a) aliena, resgatando a sua memória e lutando contra a discriminação cotidiana. A ruptura com a ideologia de embranquecimento requer, do negro, uma força só obtida quando organizado, em um movimento contra-hegemônico. Nisto consistiria a primeira grande medida preventiva para a manutenção de sua própria saúde, não somente física, mas, sobretudo, mental e social. 


\section{CONSIDERAÇÕES FINAIS}

De modo geral, a interpretação do material do conjunto das entrevistas permitiu desvelar a transversalidade das relações de gênero e de raça, em relação à posição social ocupada pela mulher, nas questões reprodutivas.

Em nível dos discursos, mulheres negras questionam a igualdade das mulheres, e propõem mais uma diferença: as diferenças nas diferenças. A idéia básica presente é de que as diferenças nas diferenças vão se sobrepondo, até não restar nada mais que o indivíduo, único em sua existência.

A escolaridade parece diferenciar as mulheres, em alguma medida. Mulheres, de escolaridade fundamental e média, com menor capacidade de inserção no mercado de trabalho, teriam menor poder aquisitivo e menores possibilidades de se movimentarem na vida pública.

De modo geral, mulheres brancas e negras investigadas têm consciência de que conquistaram maior liberdade e espaço, em relação ao mercado de trabalho, mas, olhando para suas vidas, nem sempre, essa autonomia pode ser apontada com a mesma clareza. Há, por assim dizer, uma idéia difusa de que a condição feminina está se alterando.

Diferentes formas de conceber a liberdade sinalizam, no entanto, para diferentes compreensões de sua condição de gênero e raça. Enquanto mulheres brancas problematizam a condição em que vivem e a possibilidade de exercício efetivo da liberdade, mulheres negras apontam para os benefícios da vida cotidiana, na realidade atual, e para o avanço alcançado, com a possibilidade de diálogo, no nível inter-pessoal e, por conseguinte, para a conjugalidade democrática. Entendemos que esta compreensão 
diferenciada de liberdade, entre mulheres negras e brancas, ocorre em função das diferentes condições de gênero e raça e, também, da condição social da mulher. Os três elementos, articulados, dão às mulheres a possibilidade de vivência sexual e afetiva diferenciadas, de maneira diacrônica. Enquanto mulheres brancas, ao que parece, buscam superar a dicotomia, na relação com seus parceiros, mulheres negras buscam construir uma relação conjugal, já conquistada por mulheres brancas, de nível superior, situação essa que, historicamente, não foi alcançada por elas, em parte, pela condição histórica de escravidão em que viveram as gerações que as antecederam. Como aponta BERNARDO (1998), a família negra, formada inicialmente por mãe e filho, com o advento da Lei do Ventre Livre, excluía 0 homem negro, pela sua própria condição. As mulheres negras, portanto, ocupavam um lugar central na formação dessa família. A vivência da conjugalidade, no sentido moderno do termo, com uma experiência de compartilhamento é, ao que parece, uma novidade na vida de mulheres negras. BERQUÓ (1987), ao analisar a nupcialidade da população negra, constatou maior solidão entre mulheres negras, que pode refletir uma maior valorização da conjugalidade. Percebe-se, então, neste aspecto, uma diferença étnico-racial.

Assim, enquanto mulheres brancas pensam na defasagem das mulheres, no exercício eqüitativo da liberdade, em relação aos homens, mulheres negras pensam na possibilidade de diálogo na vivência da conjugalidade. Essas diferentes concepções são especialmente relevantes para se pensarem as escolhas reprodutivas de mulheres negras e brancas e desvelar uma dada condição feminina, diferenciada por cor. Enquanto mulheres brancas partem de uma visão de que a "mulher é sempre mulher (ensino fundamental), até chegarem à visão de conquista de maior autonomia (ensino superior), mulheres negras(ensino fundamental) partem de uma visão de pouca liberdade, cujas expressões se localizam na dificuldade de ir e vir e no desejo de ampliar o espaço da rua, como espaço 
de lazer, além do trabalho, a visão limite que chegam a apresentar é a de liberdade na conjugalidade (nível superior). Esta difere, portanto, da visão alcançada por mulheres brancas, de mesmo nível de escolaridade, que apontam, sobretudo, para conquistas no mercado de trabalho e de outros espaços.

$\mathrm{Na}$ contemporaneidade, mulheres negras organizadas politizam suas questões, buscando construir uma história diferente, em que o direito de decidir pelo próprio corpo, uma bandeira feminista, passa pela mudança dos padrões de relações de gênero que, historicamente, estão inseridas em uma dinâmica diferente daquela de mulheres brancas.

A decalagem constatada entre mulheres negras e brancas explicitase, também, na concepção de mulher de que são portadoras. Constatamos que mulheres negras e brancas perceberam mudanças na inserção da mulher no mundo mas, quando retemos as concepções de liberdade, depreendemos que a liberdade da mulher branca é mais ampliada no mundo público, e a da mulher negra, restrita ao campo do privado. Enquanto a mulher branca procura privilegiar lançar-se no mundo publico, a mulher negra visa a construir a sua vida privada, dilacerada, do ponto de vista histórico, no período da colonização. As concepções de casamento, entretanto, não divergem, já que ambos os grupos apontam para a monogamia, como princípio organizador da vida sexual e reprodutiva. Isto revela que, tanto mulheres negras, como brancas, estão, ao que parece, adaptadas a padrões impostos, de uma socialização conjugal cristã e ocidental.

Mulheres brancas têm consciência de sua condição privilegiada, em função da cor. A brancura favorece de tal forma, que as conquistas de gênero não são equivalentes às das mulheres negras. Existe uma barreira simbólica, que é pautada pela cor, e que não é facilmente superada por mulheres negras. Percebe-se, assim, que existe uma dada hierarquia, que 
constrói a desigualdade entre as mulheres. Essa hierarquia, de bases simbólicas, constitui o elemento chave para a compreensão da diferença entre mulheres negras e brancas.

A discriminação desvela o diferencialismo ao extremo, colocando abaixo a suposição corrente de que existe uma dada igualdade na condição feminina, ao mesmo tempo em que revela o "jogo das identidades" (HALL 2001).

Constatamos, igualmente, que, do mesmo modo que mulheres brancas seriam diferentes entre si, mulheres negras, também o seriam e viveriam sua condição em um processo de individuação, que as singulariza. A dominação masculina se reinventa no "jogo das identidades", sobre diferentes ícones. Revelam-se processos históricos e constante transformação dos ícones, que as estigamatizam. Com isto, estamos considerando que as categorias de gênero e raça não são estáticas, nem as identidades que as sustentam.

Em síntese, pudemos observar, ao longo do trabalho, que o racismo é o que diferencia o cotidiano das mulheres, com maior prejuízo para mulheres negras, de modo que não se pode falar de igualdade de gênero, sem se pensar na desigualdade de raça.

Em relação à contracepção, observamos, também, que entre as mulheres entrevistadas, as mulheres negras, de escolaridade média, aproximam-se do padrão desenhado pelas mulheres negras de ensino fundamental, e que, entre as mulheres brancas presencia-se praticamente um mesmo padrão, em todos os níveis de escolaridade. Assim, no que diz respeito à contracepção, enquanto mulheres negras, de ensino médio, permanecem mais próximas de mulheres de ensino fundamental, mulheres brancas, de escolaridade média, aproximam-se mais, em nível de discurso, de mulheres de nível superior. 
Entre as entrevistadas, observamos que, quanto maior a escolaridade e, com isso, maior possibilidade de autonomia frente ao parceiro, maior a proporção de mulheres que usam métodos reversíveis. Em contrapartida, a opressão de gênero poderia parecer mais eficaz no caso de mulheres negras entrevistadas, portadoras de escolaridade média e fundamental, ao se tomar, como expressão, a "opção" pela laqueadura, em maior freqüência, enquanto mulheres brancas, de diferentes escolaridades, "optam", em maior proporção, por métodos de controle masculino, como vasectomia e camisinha masculina.

Com relação ao aborto, não captamos diferenças de percepção, em nível do discurso, entre mulheres negras e brancas.

Essas diferenças articulam-se às formas de conjugalidade, na medida em que, por exemplo, entre as entrevistadas, mulheres negras, de ensino médio e negras e brancas, de ensino fundamental, apresentam características de relações menos dialogadas, menos flexíveis, enquanto mulheres negras e brancas, de ensino superior, encontram-se em um patamar, em que a relação dialógica é mais presente na conjugalidade e, destas, mulheres brancas, de ensino médio, se aproximam.

Finalmente, a questão do racismo se faz presente no discurso de todas as mulheres negras entrevistadas, revelando-se como uma forma de homogeneizar as mulheres, em suas vivências. 0 racismo impede, dificulta que mulheres negras obtenham conquistas significativas na vida pública. Isto é evidenciado em discursos dessas mulheres, como apresentado no capitulo 10. Elas percebem o racismo e apontam situações em que seus direitos são negados. Diante de tal situação, há que haver uma mudança sócioeconômica e cultural significativa, para que a mulher negra possa, efetivamente, ocupar um lugar, tanto na vida publica, como na vida privada, que as identifique como sujeitos de direitos. Neste particular, a questão da assunção da negritude apresenta-se como estratégia de preservação, não 
somente da sua identidade, mas igualmente de sua saúde física e, sobretudo, mental e social. 


\section{REFERÊNCIAS}

Almeida C.C.L. Risco e saúde reprodutiva: percepção dos homens de camadas populares. Cad. Saúde Pública; 2002;18(3):797-805.

Alvarenga A T \& Schor N. Contracepção feminina e política pública no Brasil: pontos e contrapontos da proposta oficial. Saúde Soc; 1998;7(1): 87-110.

Ayres J R, França J r I, Calazans G, Salettti Filho H. Vulnerabilidade e prevenção em tempos de AIDS. In: Barbosa R, Parker R.(org.) Sexualidades pelo avesso: direitos, identidades e poder. São Paulo: Editora 34; 1999.p 49-72.

Ávila MB. Modernidade e cidadania reprodutiva. Rev Estud Fem; 1993;1:38293.

Ávila M. Direitos Reprodutivos, exclusão social e Aids. In: Barbosa R M; Parker R, (org.) Sexualidades pelo avesso: direitos, identidades e poder. São Paulo: Editora 34; 1999. p. 39-48.

Badinter E. Um amor conquistado: o mito do amor materno.Rio de Janeiro: Nova Fronteira; 1985.

Bairros,L; Castro, N.A ; Sa Barreto, V. Vivendo em sobresalto: composição étnica e dinâmica conjuntural do mercado de trabalho. Anais volume 2 Caxambu, Brasil, Minas Gerais.VII Encontro Nacional de Estudos Populacionais, ABEP, 1990. p.21-51.

Bairros L. Mulher negra: o reforço da subordinação. In: Desigualdade racial no Brasil contemporâno.Belo Horizonte: CEDEPLAR-FACE-UFMG, 1991. p.177-193.

Batista L.E. Mulheres e homens negros: saúde, doença e morte. Araraquara; 2002 [Tese de doutoramento Unesp-Araraquara] 
Barbosa R M. Negociação sexual ou sexo negociado? Gênero, sexualidade e poder em tempos de Aids. Rio de Janeiro; 1997. [Tese de doutorado Instituto de Medicina Social- UFRJ ].

Barbosa R. HIV/Aids, transmissão heterossexual e métodos de prevenção controlados pelas mulheres. Rio de Janeiro: $A B \mid A ; 2000(2)$ [paper]

Barsted L.deA.L. A revisão da modernidade a partir do olhar critica da mulher. In: Brandão, M.L.R; Bingemer,M.C.L.(org) Mulher e relações de gênero. São Paulo: Edições Loyola; 1994.

Bastos F.I. A feminização da epidemia de Aids no Brasil. Determinantes estruturais e alternativas de enfrentamento. Rio de Janeiro: $A B I A$; 2000(3)[paper]

Beijing Declaration and Plataform for Action. 1995 Fourth World Conference on Women, Beijing.

Bento M.A. Raça e Gênero no mercado de trabalho. In: Trabalho e Gênero: mudanças, permanências e desafios. São Paulo: ABEP/NEPO UNICAMP/CEDEPLAR- UFMG/ Editora 34; 2000. p 295-307.

Beozzo J.O. A família escrava e imigrante na transição do trabalho escravo para o livre. In: Marcilio M.L.(org.) Família, Mulher, Sexualidade e igreja na Historia do Brasil. São Paulo: Edições Loyola; 1993.

Bernardo T. Memória em branco e negro: olhares sobre São Paulo. São Paulo: EDUC: Fundação Editorada UNESP; 1998.

Berquó E. Pirâmide da Solidão? V Encontro de Estudos Populacionais-ABEP - Águas de São Pedro; 1998 [ mimeo].

Berquó E. Estudo da dinâmica populacional do negro no Brasil. Campinas:Texto Nepo 9; 1986 [mimeo]. 
Berquó E. Nupcialidade da população negra no Brasil. Campinas: Texto Nepo 11, 1987[mimeo].

Berquó E. Notas sobre os arranjos familiares por raça no Brasil. São Paulo/Campinas: CEBRAP/NEPO e Rio de Janeiro: Seminário Internacional sobre países da diáspora africana, 1992[ mimeo].

Berquó E. Brasil, um caso exemplar: anticoncepção e partos cirúrgicos à espera de uma ação exemplar. Rev Estud Fem; 1993;(1):3336-81.

Berqúo E. Esterilização e raça em São Paulo. Revista Brasileira de Estudos da População. 1994;(11)1: 19-26.

Berquó E. \& Cavenaghi S. Direitos Reprodutivos de mulheres e homens face à nova Legislação sobre esterilização voluntária. Trabalho apresentado no XIII Encontro da Associação Brasileira de Estudos Populacionais, realizado em Ouro Preto, Minas Gerais, Brasil, de 4 a 8 de novembro de 2002.

Berquó E. Ainda a questão da esterilização feminina no Brasil. In: Giffin K \& Costa S.H.(org) Questões da Saúde Reprodutiva. Rio de Janeiro: FioCruz; 1999.

Bobbio N. I gualdade e Liberdade. Rio de Janeiro: Ediouro; 1997.

Bourdieu P. O poder simbólico. Lisboa: Difel - Difusão Editorial; 1989.

Bourdieu P. A economia das trocas simbólicas. São Paulo: Editora Perspectiva; 1992.

Bourdieu P. Novas reflexões sobre a dominação masculina. In: Meyer M J M D E et al. (org). Gênero e saúde. Porto Alegre: Artes Médicas; 1996. p.28-40.

Bourdieu P. Contrafogos: táticas para enfrentar a invasão neoliberal. Rio de Janeiro:J orge Zahar Editor; 1998. 
Bruschin C. Mulher e mundo do trabalho: ponto de vista sociológico. In: Brandão M.L.R. \& Bingermer M.C.L.(org.) Mulher e relações de gênero. São Paulo : Edições Loyola;1994(a) p.115-129.

Bruschini C. 0 trabalho da mulher no Brasil: tendências recentes. In: Saffioti H.I.B. \& Muñoz-Vargas (org.) Mulher brasileira é assim. Rio de Janeiro: Rosa dos Tempos/NIPAS: Brasília, DF: UNICEF; 1994(b) p.63-93.

Bruschini C. Gênero e trabalho no Brasil: novas conquistas ou persistência da discriminação. In: Rocha M.I.B (org.). Trabalho e gênero: mudanças, permanências e desafios. São Paulo: Editora 34: ABEP,NEPO/Unicamp,CEDEPLAR/UFMG; 2000. p 13-58.

Camargo, M. Violência e saúde: ampliando políticas pública. Jornal da redesaúde, 2000( 22):6-8.

Camarano A.A; Araujo H.E; Carneiro I.G. Tendências da fecundiade brasileira no século XX: uma visão regional. In: Giffin K; Costa S.H.(org) Questões da saúde reprodutiva. Rio de Janeiro: Editora FioCruz; 1999. 95 111.

Carvalho, M.L. de 0 . Antecedentes e conseqüências da esterilização feminina: trajetórias em busca do controle da própria fecundidade. São Paulo 2001 [ Tese de doutorado - FSP/USP].

Cecatti J.G.; Pires H.M.B; Goldenberg P. Cesárea no Brasil: um direito de opção? In: Galvão L; Diaz J.(org) Saúde Sexual e reprodutiva no Brasil. São Paulo: Hucitec/Population Council;1999. p 237-258.

Chauí M. Repressão sexual: essa nossa (des)conhecida.São Paulo:Editora Brasiliense. (10 edição 1984) 12ㅇe edição1991

Chauí M. Participando do debate sobre mulher e violência. Perspectivas antropológicas da Mulher 4: Sobre Mulher e violência. Rio de Janeiro: Zahar Editores; 1985. 
Chachan A S. Condicionantes socioeconômicos, etários e raciais. Jornal da RedeSaúde; 2001(23):44-47

CONFERENCIA REGI ONAL DE LAS AMÉRICAS. Preparativos de la Conferencia mundial contra el Racismo, la Discriminación Racial, la Xenofobia y las Formas Conexas de Intolerância Santiago de Chile, 5 a 7 de diciembre de 2000 (documento on line).

Corrêa S. \& Ávila M.B. Direitos Sexuais e reprodutivo - Pauta Global e Percursos Brasileiros. In: Berquó E.(org.) Sexo \& Vida: panorama da saúde reprodutiva no Brasil. Campinas: Editora da Unicamp; 2003. p.17-78.

Costa A M. O PAISM - uma política de assistência à saúde da mulher a ser resgatada. São Paulo: Comissão de Cidadania e Reprodução; 1992.

Costa J. F. Violência e Psicanálise. Rio de Janeiro: Graal; 1985. p.103-116.

Costa S.G. Proteção social, maternidade transferida e lutas pela saúde reprodutiva. Revista Estudos Feminista ; 2002; (2):301-323.

Cunha EMG de P. Mortalidade Infantil e raça: as diferenças da desigualdade. Jornal da RedeSaude; 2001;(23):48-50.

DaMatta R. Carnavais, Malandros e Herois: para uma sociologia do dilema brasileiro. Rio de Janeiro: Editora Guanabara; 1990.

Darcy de Oliveira R. O elogio da diferença:o feminino emergente. São Paulo: Brasiliense; 1999.

Declaração de Itapecirica da Serra das Mulheres Negras Brasileiras, I tapecirica da Serra, 22 de agosto de 1993.

Del Priore M. Estudo CEDHAL 4 - A maternidade da mulher negra no período colonial brasileiro. São Paulo: CEDHAL; 1989.

DeSouza E; Baldwin J.R; Rosa F.H. da. A construção social dos papéis sexuais femininos. Psicologia: Reflexão e Crítica. 2000; 13(3):485-496. 
Domingues P.J. Negros de Almas Brancas? A ideologia do branqueamento no interior da comunidade negra em São Paulo, 1915-1930. Estudos AfroAsiáticos. 2002,ano24; no 3, : 563-599.

Dumont L. O individualismo: uma perspectiva antropológica da ideologia moderna. Rio de Janeiro: Editora Rocco; 1985.

Documento da Articulação de Mulheres Negras Brasileiras "Rumo à III Conferência Mundial Contra o Racismo". Rio de Janeiro: Articulação de Negras Brasileiras; 2000.

Fanon F. Pele Negra, Mascaras Brancas. Rio de Janeiro: Outra Gente Editora Fator; 1983.

Feres-Carneiro T. Casamento contemporâneo: o difícil convívio da individualidade com a conjugalidade. Psicol. Reflex. Critica;1998(11):2-12.

Ferreira R.F.Afro descendente : identidade em construção. Educ: São Paulo; Pallas: Rio de J aneiro; 2000.

Folha de São Paulo. "Especial Racismo cordial: a maior e mais completa pesquisa sobre o preconceito de cor entre os brasileiros." 25/06/1995.

Fonseca W.; Masago C; Correia L.L.; Parente J.AM; Oliveira F.C. Determinantes do aborto provocado entre mulheres admitidas em hospitais em localidades da Região Nordeste do Brasil. Revista Saúde Pública. 1996; (30) 1-15.

Foucault M. História da sexualidade: I - Vontade de saber. Trad. De M.T.C. Albuquerque e J.G. Albuquerque. Rio de Janeiro: Graal; 1984.

Foucaul M. Microfísica do poder. Rio de Janeiro:Graal; 1993.

Foucault, M. A mulher/Os rapazes da historia da sexualidade. Rio de Janeiro: Paz e Terra; 1997.

Freire G. Casa - Grande \& Senzala. São Paulo: Editora Global; 2003. 
Galvão L. Saúde sexual e reprodutiva, saúde da mulher e saúde materna: a evolução dos conceitos no mundo e no Brasil. In: Galvão L \& Diaz J. Saúde sexual e reprodutiva no Brasil: dilemas e desafios. São Paulo: Editora Hucitec/Population Council, 1999.

Giddens A. As conseqüências da modernidade. São Paulo: Editora Unesp; 1991.

Giddens A. A transformação da intimidade: sexualidade, amor \& erotismo nas sociedade modernas. São Paulo :Unesp; 1993.

Giddens A. Para além da direita e da esquerda. São Paulo: Unesp; 1996.

Gilliam A. Globalização, identidade e os ataques à igualdade nos Estados Unidos: esboço de uma perspectiva para o Brasil. In: Feldmam-Bianco B \& Carpinha G.(org.). Estudos de Cultura e Poder: Identidades. São Paulo: Editora Hucitec; ,2000. p 73-105.

Gonzalez L. A mulher negra na sociedade brasileira. In: Luz M. O lugar da mulher. Rio de Janeiro: Graal ;1982.p.87-106.

Gould S.J. A falsa medida do homem.São Paulo: Martins Fontes; 1991.

Gualberto L.N. Comportamento contraceptivo, raça/cor da mulher no Brasil. Belo Horizonte, 2003 [Tese de mestrado - CEDEPLAR - UFMG]

Guimarães AS.A. Las causas de la pobreza negra em el Brasil algumas reflexiones. In: Region América latina y el Caribe. Documento de Trabajo no9 sobre Desarrollo Sostenible La raza y la pobreza: Consulta interagencias sobre afrolatinoamericanos, Washington, D.C. 2000.

Guimarães A.S.A Racismo e anti-racismo no Brasil. Novos Estudos CEBRAP. nov.1995; 43.

Guimarães K. Nas raízes do silêncio: a representação cultural da sexualidade feminina e a prevenção do HIV/Aids. In: Parker $\mathrm{R} \&$ Galvão J (org.) 
Quebrando o silêncio - mulheres e Aids no Brasil. Rio de Janeiro: Relume Dumará; 1996. ( História Social da Aids, 7): 89-113.

Hall S. A identidade cultural na pós-modernidade. Rio de Janeiro: DP\&A editora; 2001.

Hall S. Quem precisa da identidade? In: Silva, T.T. (org.) Identidade e diferença. Petropolis:Editora Vozes; 2000. p.103-133.

Hasenbalg C. Relações raciais no contexto nacional e internacional. Hasenbalg C.; Munanga ; Schwarcz L.M. Estudos \& Pesquisas: Racismo: perspectivas para um estudo contextualizado da sociedade brasileira. Rio de Janeiro: Eduff; 1998. p.9-41.

Hasenbalg C. As desigualdades raciais revisitadas. Ciências Sociais Hoje, 2. Movimentos Sociais Urbanos, Minorias Étnicas e outros Estudos; 1983. p.179 - 197.

Henriques R. Texto para Discussão no807 Desigualdade Racial no Brasil: Evolução das condições de vida na década de 90 . Brasília: IPEA[www.ipea.gov.br], 2001.

Hilferding M. Reunião de 11 de janeiro de 1911- Ata da Sociedade Psicanalítica de Viena. In: Hilferding M.; Pinheiro T.; Vianna H.B. As bases do amor materno. São Paulo: Escuta; 1991. .85-101.

Hita M.G. Esterilização e raça: pontos para refletir sobre a sexualidade brasileira.[mimeo - versão eletrônica] S/D.

Honneth A. A luta por reconhecimento: a gramatica moral dos conflitos sociais. São Paulo: Editora 34; 2003.

Ianni Oi. A racialização do mundo. Revista de Sociologia da USP. 1996; $8(1): 1-23$. 
ICPD- International Conference on Population and DevelopmentPrograma of Action Cairo, Egito; 1994.

J acquard A . Elogio da diferença. São Paulo: Martins Fontes; 1991.

Jornal da redesaúde. Informativo da Rede Nacional Feminista de Saúde e Direitos Reprodutivos. São Paulo, novembro 2000; №22.

Jornal da redesaúde. Informativo da Rede Nacional Feminista de Saúde e Direitos Reprodutivos. São Paulo. março ; № 23.

La Guardia K D. Aids and reprodutive health: women's perpectives. In: Chen L C et. Al. Aids and women's reprodutive Health Edited by. New York, Plenumm Press; 1991. p.17-25.

Leal M.do; Gama S.G.N.;Cunha C.B. Desigualdades raciais, sociodemograficas e na assistência ao pré-natal e ao parto. Municipio do Rio J aneiro; 1999 - 2001 [ paper no prelo] .

Leite M.M(org.). A condição feminina no Rio de Janeiro Século XIX: Antologia de textos de viajantes estrangeiros. São Paulo: HUCITEC/ Edusp; 1993(a).

Leite M.L.M. A mulher das camadas médias entra no mercado de trabalho. In: Marcilio M.L.(org.)Família, Mulher, Sexualidade e Igreja na história do Brasil.São Paulo: Edições Loyola; 1993(b). p.191-196.

Lima M. Trajetória educacional e realização sócio-economica das mulheres negras. Revista Estudos Feministas, 1995; 3 (2).

Lipovestsky G. A terceira mulher: permanências e revolução do feminino. São Paulo: Cia das Letras; 2000.

Loyola M A. Percepção e Prevenção da AIDS no Rio de Janeiro. In: Loyola M.A; organizador. Aids e sexualidade. o ponto de vista das ciências sociais. Rio de Janeiro: Relume Dumará; 1994. p. 20-72. 
Lopes F. Mulheres negras e não negras vivendo com HIV/Aids no Estado de São Paulo, São Paulo, 2003 [Tese de doutorado - Depto de Epidemiologia da Faculdade de Saúde Pública/USP].

Louro G.L. Gênero, sexualidade e educação:uma perspectiva pósestruturalista.Petrópolis: Editora Voze;1999.

Maggie I. Aqueles a quem foi negada a cor do dia: as categorias cor e raça na cultura Brasileira.In:ChorM \& Santos R.V.(org.) Raça, ciência e sociedade. Rio de Janeiro: Editora FioCruz/Cento Cultural Banco do Brasil; 1996. p.225234

Marchi N.M et al. Opção pela vasectomia e relações de gênero. Cad. Saúde Publica. 2003; 19(4):1017-1027.

Martins A L Maior risco para mulheres negras no Brasil. Jornal da redesaúde, 2001; 23:37-40.

Meihy J.C.S.B. Manual de História Oral. São Paulo: Edições Loyola; 1996.

Minayo M C de S. O desafio do conhecimento: pesquisa qualitativa em saúde. São Paulo: Hucitec/ Abrasco; 1996.

Ministério da Saúde. Relatório Final: Mesa Redonda sobre a saúde da população negra. Brasília, agosto de 1996 [mimeo].

Ministério da Justiça. Relatório do Comitê Nacional para Preparação da Participação Brasileira na III Conferência Mundial das Nações Unidas contra o Racismo, Discriminação racial, Xenofobia e Intolerância Correlata. Brasília; 2001.

Ministério da saúde.Série B: Textos básicos de Saúde. 6 Assistência integral á saúde da mulher - bases de ação programática, Brasília, 1984.

Ministério da Saúde. Mesa Redonda sobre A Saúde da População Negra. Relatório Final. Brasília.1996. 
Moura E.B.B.de. Estudos Cedhal 3 Trabalho feminino e condição social do menor em São Paulo(1890 - 1920). São Paulo, CEDHAL;1988.

Munanga K. Negritude Afro-brasileira:perspectivas e dificuldades. Revista de Antropologia. 1990: 109- 117.

Munaga K.Teorias sobre o racismo. In: Hasenbalg C. A; Munanga K; Schwarcz L.M. Estudos \& Pesquisas: Racismo: perspectivas para um estudo contextualizado da sociedade brasileira. Rio de Janeiro:Eduff; 1998. p.43-65.

Munanga K. Mestiçagem e experiências interculturais no Brasil.In: Negras Imagens. São Paulo:Editora da Universidade de São Paulo/Estação Ciência; 1996. p.179-193.

Munanga K. A identidade negra no contexto da globalização. Ethnos Brasil; 2002; (1)11:20

Nogueira I.B. Significados do corpo negro São Paulo; 1998 [Tese de doutorado - Instituto de Psicologia/USP]

Nogueira 0. Tanto preto quanto branco: estudos de relações raciais. São Paulo: T. A Queiroz; 1985.

Nogueira R. Mulher negra e obesidade. In: Werneck J; Mendonça M; White E.C(org.) O Livro da Saúde da Mulher Negra: nossos passos vêm de longe. Rio de Janeiro: Pallas/Criola/GlobalExchange,; 2000.p.199-201.

O'leary S \& Cheney B. A tripla ameaça: dossiê panos. Trad. de Ana Dourado. Rio de Janeiro: ABIA/ SOS CORPO/ Panos Institute; 1993.

Oliveira F. Saúde da população negra Brasil.Ano 2001. Brasília: Organização Pan-Americana de Saúde; 2003.

Oliveira F. As síndromes falciformes e o PAF/MS. In: Werneck J; Mendonça M; White E.C (org.) O Livro da Saúde da Mulher Negra: nossos passos vêm de longe. Rio de Janeiro: Pallas/Criola/GlobalExchange; 2000. p 158-166. 
Oliveira M.C F.A. de. Trabalho, família e condição feminina: considerações sobre a demanda por filhos. Revista Bras. de Est. Populacionais. 1989; 6 (1): 25-33.

Oliveira R.C. Identidade, Etnia e Estrutura Social. São Paulo: Livraria Pioneira Editora; 1976.

Oliveira R.C. 0 trabalho do antropólogo. Brasília Paralelo 15/ São Paulo: Editora Unesp; 2000.

Osis M.J.D; Faundes A O; Sousa M.H. de O; Bailey P. Consequências do uso de métodos anticoncepcionais na vida das mulheres: o caso da laqueadura tubária. Cad. Saúde Pública. 1999; 15(3)521-532.

Osis MJ.D et al. Dificuldade paras obter informações da população de mulheres sobre aborto ilegal. Rev Saúde Pública ; 1996(30):444-5.

Osis M J et al. PAISM: um marco na abordagem da saúde reprodutiva no Brasil. Cad Saúde Pública. 1998; 14: 25 - 32.

Osis M.J. Laqueadura e representação acerca da sexualidade e do papel reprodutivo. São Paulo;2001 [Tese de doutorado apresentada ao Departamento de Saúde Materno Infantil - FSP/USP]

Ottmann G. Movimento sociais urbanos e democracia no Brasil. Novos Estudos. 1995; 41:186-207.

Paixão M.J.P. Desenvolvimento humano e relações raciais. Rio de J aneiro:DP\&A edictora; 2003.

Parker R. Corpos, prazeres e paixões: a cultura sexual no Brasil contemporâneo. São Paulo: Best Seller;1991.

Parker R. Diversidade sexual, análise sexual e a educação sexual sobre a Aids no Brasil. In: Loyola M.A.(org.) Aids e sexualidade: o ponto de vista das ciências Humanas. Rio de Janeiro: Relume Dumará; 1994. p.141-159. 
Pateman C. O contrato sexual. Rio de Janeiro: Paz e Terra; 1993.

Patton M.Q. Qualitative evaluation and research methods. London: Sage Publications; 1990.

Pereira W.R. O processo de medicalização do corpo feminino. In: Scavone, L. \& Batista, L.E.(org) Pesquisa de gênero: entre o público e o privado. Araraquara: Faculdade de Ciências e Letras, Laboratório Editorial; 2000. p.127-152.

Perpétuo I.H.O. Raça e acesso às ações prioritárias na agenda da saúde reprodutiva. Jornaldaredesaúde; 2000(22): 10-16 [encarte]

Perpetuo I.H.O. Esterilização feminina: a experiência da região Nordeste, 1980-91.Belo Horizonte [Tese de doutorado - CEDEPLAR-UFMG].

Pierucci A . F. Ciladas da diferença. São Paulo: Editora 34; 2000.

Pinheiro T. Reflexões sobre as bases do amor materno. In: Hilferding M; Pinheiro T.; Vianna H.B. As bases do amor materno. São Paulo: Escuta; 1991. p.103-134.

Pinho M.D. et al. Juventude, Raça e Vulnerablidades Trabalho apresentado no no XIII Encontro da Associação Brasileira de Estudos Populacionais em novembro de 2002[mimeo].

Pinto E.A; Boulos R; Assis M. A saúde mental da população negra: uma breve reflexão a partir da experiência com grupos de auto-ajuda. In: Werneck J; Mendonça M; White E.C(org) O Livro da Saúde da Mulher Negra: nossos passos vêm de longe. Rio de Janeiro: Pallas/Criola/GlobalExchange, 2000.p.171-175

Pinto E. Ventres Livres: 0 aborto numa perspectiva étnica e de gênero. São Paulo: FalaPreta!/Terceira Margem; 2002. 
Pinto E. \& Souzas R. A mortalidade materna e a questão Raça/Etnia: importância da Lei do Quesito Cor no Sistema de Saúde. Perspectivas em Saúde e Direitos Reprodutivos. Informativo Semestral MacArthur, no 5/Ano 3 , maio de 2002.p.28-30.

Pinto L. Pierre Bourdieu e a Teoria do Mundo Social. Rio de Janeiro:Editora FGV;2000.

Pirotta KCM. A esterilização: do mito da emancipação ao desvelamento da subalternidade. São Paulo; 1998 [Dissertação de Mestrado - Faculdade de Saúde Pública da USP].

PNUD/OPAS. Política Nacional de Saúde da População Negra: uma questão de equidade. Workshop Interagencial Saúde da População Negra realizado em Brasília nos dias 6 e 7 de dezembro de 2001.

Prefeitura Municipal de São Paulo. Introdução do quesito cor no sistema municipal de informação da saúde. São Paulo: CEFOR; 1992.

Rago M. Do cabaré ao lar: a utopia da cidade disciplina. Rio de Janeiro: Paz e Terra; 1987.

Ramos P.V.; Drumond Jr. M. Levantamento da morbidade atendida na rede ambulatorial da Secretaria Municipal da Saúde de São Paulo- demanda do sexo feminino por cor. São Paulo: Prefeitura do Município de São Paulo, Secretaria Municipal de Saúde, Centro de Epidemiologia, Pesquisa e Informação; 1993.

Rios Neto E. R. \& Wajnman S. Participação feminina no mercado de trabalhom no Brasil: elementos pra projeção de níveis de tendências. In: Anais 3 IV Encontro de Estudos Populacionais, Caxambu, ABEP, 1994.

Robinson M. Gender dimension of racial discrimination United Nations: Office of the High Commissioner for Human Rights; 2001. 
Roch M.I.B. da \& Andalaft Neto J. A questão do aborto - aspectos clínicos, legislativos e políticos. In: Berquó, E. Sexo \& Vida: panorama da saúde reprodutiva no Brasil. Campinas: Editora da Unicamp; 2003. p.257-318.

Rodrigues G. de C. O dilema da maternidade, São Paulo, 1993 [Tese de doutorado-PUC-SP- Ciências Sociais].

Rodrigues N. Educação: da formação humana à construção do sujeito ético. Educação \& Sociedade; 2001, ano XXII, ํo76.

Roland E. Saúde reprodutiva da população negra no Brasil: um campo em Construção. In: Perspectivas em Direitos Reprodutivos. Informativo Semestral da Fundação MacArthur, 2001; 4:17- 24.

Roland E. O movimento de mulheres negras brasileiras: desafios e perspectivas. In: Guimarães,A . S. e Huntley,L; (org). Tirando a MascaraEnsaios sobre o racismo no Brasil. São Paulo: Paz e Terra; 2000. p.237-256.

Roland E. Eu fiz aborto: aborto e clandestinidade. Werneck, J; Mendonça, M. White, E.C.(org) O Livro da Saúde da Mulher Negra: nossos passos vêm de longe. Rio de Janeiro: Pallas/Criola/GlobalExchange; 2000. p.130-136.

Roland R.Direitos Reprodutivos e Racismo no Brasil. Estudos Feministas. 1995; 3 (2): 506-514.

Rosental M. e Rudin P. Pequeno Dicionário Filosófico(tradução de Guarani Gallo e Rudy Magherito. São Paulo: Livraria Exposição do Livro; 1959.

Saffioti H.I.B. Rearticulando gênero e classe social. In: Costa, a de 0 \& Bruschini, C. Uma questão de gênero. Rio de Janeiro: Rosa dos Tempos; São Paulo: Fundação Carlos Chagas;1992.p.183-215.

Saffioti H.I.B. \& Almeida, S.S.de. Violência de gênero: poder e impotência. Rio de J aneiro: Livraria e Editora Revinter Ltda, 1995.

Saffioti H.I.B. O poder do macho. São Paulo: Moderna; 1987. 
Sansone L. As relações raciais em Casa Grande Senzala revisitadas. Livio Sansone, 1996 Maio C M e Santos, R V (org). Raça, Ciência e Sociedade. Rio de Janeiro: Editora FioCruz / Centro Cultural Banco do Brasil, 1996. p.207217.

Sant'Anna W. Desigualdade étnico /raciais e de gênero no Brasil : as revelações possíveis do IDH e do IDG. Jornal da redesaúde, 2001(23): 16 19.

Santos J.R dos. O que é racismo. São Paulo: Abril Cultura/Brasiliense; 1984. Santos B.S. Por uma concepção multicultural de direitos humanos. In: Feldmam-Bianco, B \& Carpinha, G.(org.) Estudos de Cultura e Poder: I dentidades. São Paulo: Hucitec; 2000 p.19-39.

Santos G.A . Selvagens, exóticos, demoníacos. Idéias e imagens sobre uma gentes de cor preta. Estudos Afro-Asiáticos. 2002; 24 (2): 275-289.

Santos N J. As mulheres e a AIDS, São Paulo; 1994 [Dissertação de Mestrado, Faculdade de Saúde Pública da USP].

Sarti C.A. A família como espelho: um estudo sobre a moral dos pobres. Campinas, SP: Autores Associdados, 1996.

Sartre J.P; Reflexões sobre o Racismo. São Paulo: Difusão Europeia do Livro, 1970.

Scavone L. \& Cortes G. Do subjetivo ao social: implicações sociológicas do aborto. In: Scavone, L. \& Batista, L.E.(org) Pesquisa de gênero: entre o público e o privado. Araraquara: Faculdade de Ciências e Letras, Laboratório Editorial; 2000. p.27-48.

Scavone, L. Anticoncepcion, aborto y tecnologias conceptivas: entre la salud, la ética y los derechos. In:Sacavone, L(org). Genero y salud reprodutiva em America Latina. Catargo: Libro Universitário Regional, 1999 p. 21-56. 
Schwarcz L.M. Sob o signo da diferença: a construção de modelos raciais no Contexto brasileiro.In: Hasenbalg C; Munanga K; Schwarcz L.M. Estudos \& Pesquisas: Racismo: perspectivas para um estudo contextualizado da sociedade brasileira. Rio Janeiro: Eduff; 1998.p. 67-103.

Scott J. Gênero: uma categoria útil para a análise histórica. Trad. De Dabat C e Ávila M B. Recife: SOS- Corpo; 1991.

SEADE Fundação Boletim Mulher e Trabalho. Publicação trimestral, São Paulo, 2001(3): 14.

Seade $\quad$ Fundação. $\quad$ Mulher em dados http://www.seade.gov.br/spmulher/SAU] acessado em 21/11/2003.

Seade F. Boletim 4 [www.seade.gov.br/mulherboletim_04].

Seade F. Mulheres segundo origem étnica- Pesquisa de Condições de Vida na Região Metropolitana de São Paulo. São Paulo: Fundação SEADE; 1994.

Seidel J. The Ethnograph[programa de computador] Salt Lake City UT: Qualis Research Associates; 1998.

Silva T.T. da (org) Identidade e diferença: a perspectiva dos estudos culturais. Petropolis: Editora Vozes; 2000.

Silva N. V. Cor e o processo de realização sócio econômica. Ciências Sociais Hoje, 2 ; 1998:198 - 210.

Simmel G. A metrópole e a vida mental. In: Velho O G. O fenômeno urbano.Rio de Janeiro: Editora Guanabara;1987. p.10-25.

Simões Barbosa RH. As mulheres, a Aids e a questão metodológica: desafios. In: Czeresnia D et al (org). Aids: Pesquisa Social e Educação. Rio de J aneiro: Hucitec/ABRASCO; 1995: 65-83. 
Simões Barbosa R H \& Vilela W. A trajetória feminina da Aids. In: Parker R \& Galvão J (org.). Quebrando o silêncio - mulheres e Aids no Brasil. Rio de Janeiro: Relume Dumará; 1996 (História Social da Aids, 7):17-32.

Soares S. Discriminação de gênero e de raça no mercado de trabalho. Mercado de trabalho: conjuntura e análise; 2000; № 13. p.45-51.

Souza V.C. Mulher negra e miomas uterinos:uma incursão na área da saúde. São Paulo, 1995 [Tese de mestrado-PUC-SP].

Souza V.C Sob o peso dos temores: mulheres negras, miomas uterinos e hietrectomia. São Paulo, 2002 [Tese de doutorado em Ciências Sociais PUC-SP].

Souza V.C. A prevalência de miomas uterinos em mulheres negras: as dificuldades e avanços na coleta e análise dos dados com recorte racial. In:Werneck J; Mendonça M; White E.C (org) O Livro da Saúde da Mulher Negras: nossos passos vêm de longe. Rio de Janeiro: Pallas/Criola/Global Exchange; 2000. p.88-118.

Souzas R. Sob o signo de Marte: relações conjugais, gênero e saúde reprodutiva de mulheres de baixa renda em São Paulo. São Paulo; 2000 [Dissertação de Mestrado apresentada ao Departamento de Saúde Materno Infantil da FSP/USP].

Souzas R. \& Alvarenga AT. Da negociação às estratégias: relações conjugais e de gênero no discurso de mulheres de baixa renda em São Paulo. Saúde e Sociedade 2001;10(2):15-34.

Suarez M; Machado L.Z; Bandeira L.M. Violência, sexualidade e saúde reprodutiva.In: Galvão L \& Díaz J.(org) Saúde sexual e reprodutiva no Brasil:dilemas e desafios. São Paulo: Editora Hucitec: Population Council; 1999. p.198-208 
Szwarcwald C L. et al. A disseminação da epidemia da Aids no Brasil, no período de 1987 - 1996: uma análise espacial. Cadernos de Saúde Pública. 2000; 16 (supl.1):7-19.

Tanaka ACD'A \& Alvarenga A.T. Tecnologia e medicalização na concepção e anticoncepção. In: Galvão L \& Díaz J.(org) Saúde sexual e reprodutiva no Brasil:dilemas e desafios. São Paulo: Editora Hucitec: Population Council; 1999. p.198-208

Telles V.da S. Direitos Sociais: afinal do que se trata? Belo Horizonte: Editora UFMG; 1999.

Torres C. Equidade em Saúde: uma visão pelo prisma da etnicidade. Programa de Políticas Públicas e Saúde e Desenvolvimento Humano [mimeoversão preliminar] Washington D.C: OPAS.

Trigo M.H.B. A mulher universitária: códigos de sociabilidade e relações de gênero. In: Novos olhares: mulheres e relações de gênero no Brasil. São Paulo: Marco Zero: Fundação Carlos Chagas; 1994. p.89-110.

Venturi J r. Democracia e Autonomia Moral: Universalismo moral e relativismo ético em teorias normativas da democracia. São Paulo; 2003 [Tese de doutorado em Ciência Política - FFLCH/USP].

Veríssimo E. O prisioneiro. São Paulo: Editora Globo;1995.

Viana O. Ensaios Inéditos. Campinas: Editora da Unicamp;1991.

Vieira E M. A esterilização de mulheres de baixa renda em região metropolitana do sudoeste do Brasil e fatores ligados a sua prevalência. Rev de Saúde Pública; 1994;(28):440-8.

Vieira E A M. Políticas públicas e contracepção no Brasil. In Berquo E.(org) Sexo \& Vida: panorama da saúde reprodutiva no Brasil. Campinas: Editora Unicamp; 2003. p.151-196. 
Vieira EAV. Medicalização do corpo feminino. In: Costa S.H. Questões da Saúde Reprodutiva. Rio de J aneiro: Editora FioCruz; 1999.p.67-78.

Werneck J; Mendonça M; White E.(org); O livro da Saúde das Mulheres negras: nossos passos vêm de longe. Rio de J aneiro: Pallas:Criola; 2000.

White ECO. Amor não justifica: mulheres negras e violência doméstica. In: Werneck J; Mendonça M; White E.(org); O Livro da Saúde da Mulher Negra:nossos passos vêm de longe. Rio de Janeiro: Pallas/Criola/GlobalExchange; 2000. p.147-152.

Wood C. Categorias censitárias e classificações subjetivas no contexto de raça no Brasil. In: Desigualdade racial no Brasil contemporâneo. Belo Horizonte: CEDEPLAR- FACE- UFMG; 1991. p.93-111. 
ANEXOS 
ANEXO I Formulário semi- estruturado de entrevista

Universidade de São Paulo/Faculdade de Saúde Pública/

Departamento de Saúde Materno Infantil

PESQUISA sobre: Gênero e Raça: intersecções no campo da saúde reprodutiva

1. Nome:

2.I dade( em anos completos):

3.Local de nascimento:

Cidade: Estado

4. Tempo de residência em São Paulo( Capital):

5. Qual é a sua cor? ( autoclassificação) Cor do parceiro

5.1 Classificação da cor pelo entrevistado

6. Qual é a sua escolaridade? ( série completada)

7. Continua estudando? $\square$ SIM $\square$ NÃO

NÃO SE APLICA

8. A sra trabalha?

$\square$ SIM $\square$ NÃO Espeficicar motivo Caso não (Passar para a Q. 10)

9. Qual é a sua ocupação? ( descrever detalhadamente o que faz como trabalho remunerado, se é empregada, se trabalha por conta própria, se tem cargo de chefia especificar número de funcionários que supervisiona, se for proprietária/sócia de firma dizer o ramo de atividade e no-de empregados)

10. Além do seu salário tem alguma outra renda?

$\square$ SIM $\quad$ Especificar

$\square$ NÃO 
11. A sra contribui para o orçamento familiar?

$\square$ SIM $\square$ NÃO

12. Seu marido/companheiro trabalha?

$\square$ SIM $\square$ NÃO Especificar o motivo

(Passar para a Q. 15) ]

13.Qual a ocupação dele? ( descrever detalhadamente o que ele faz, se é empregado, se trabalha por conta própria, se tem cargo de chefia especificar número de funcionários que supervisiona, se for proprietária/sócia de firma dizer o ramo de atividade e $\mathrm{n}$-de empregados)

14. Além do salário ele tem alguma outra renda?

$\square$ SIM Especificar:

$\square$ NÃO

15. A sra poderia me dizer qual é a renda total de sua família? 
$\square$ SIM $\quad$ Especificar:

$\square$ NÃO

$\square$ NÃO SABE

16. Quem é que a sra. considera que é o "chefe" da sua família?

\section{Por que?}

17. E quem é o maior responsável, na sua família, pelo sustento da sua casa?

18. Qual é a sua situação conjugal? $\square$ casada(o) $\square$ união livre

19. Tempo de união: 19. I dade ao casar:

20. Já viveu antes com outra pessoa?

$\square$ SIM Especificar tempo:

$\square$ NÃO 
21. Me fale um pouco sobre a história da sua vida reprodutiva ( mulheres)

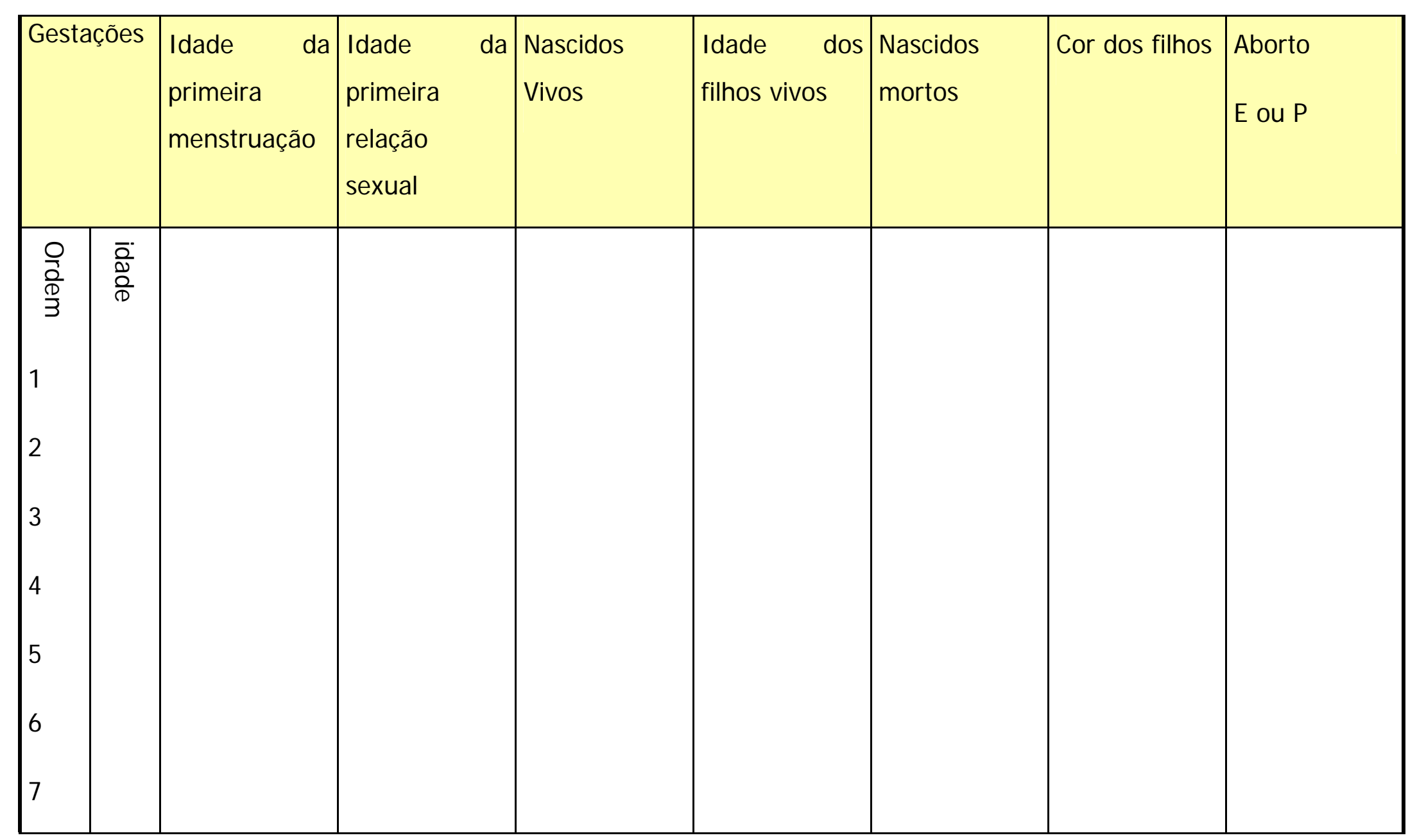


22 A sra. conhece algum método para evitar gravidez?

$\square$ SIM $\square$ NÃO

23.Que métodos a sra. conhece?
a)
b).
c).
d).
e)
f).

24.Quais métodos a sra. já utilizou?

a)

b).

c)

d).

e)

f)

25.Qual o método que a sra. prefere?

Por quê?

26.Qual método que sra. não gosta?

Por quê?

27.A sra. está usando algum método atualmente?

$\square \mathrm{SIM}$

$\square$ NÃO ( passar para Q. 30) 
28.Qual método que está usando atualmente?

39. Porque escolheu este?

30. Por que não está usando nenhum método?

31. Sobre este assunto, a sra gostaria de dizer mais alguma coisa? 
ANEXO II Roteiro temático para entrevista em profundidade

Universidade de São Paulo/Faculdade de Saúde Pública/Departamento de Infantil PESQUISA sobre: Gênero e raça: intersecções no campo da saúde reprodutiva

Nome "Codnome" escolhido pela entrevistada

1. 0 que você/sra acha que é ser mulher no mundo de hoje ?

2.0 que a sra./você acha da maior liberdade que as mulheres tem hoje em dia? Explorar: - as concepções que ela tem acerca das relações de gênero, como se sente em relação a isto.

- Como vê a relação liberdade feminina versus liberdade masculina

3.0 que a sra./você acha do trabalho da mulher fora de casa?

- reter pontos relativos a conflitos nas relações de gênero

- trabalho da mulher como forma de independência

4.A sra./você acha que as mulheres são muito, mais ou menos, ou pouco discriminadas em nosso meio?

- Explorar: no que são discriminadas e o porque

- Quem discrimina mais, o homem, outras mulheres e em que situação.

5. A sra./você acha que tem discriminação de cor no nosso meio?

6. O que a sra./você acha que é ser uma mulher negra ( preta ou parda) em nosso meio?

7. 0 que a sra./você acha que é ser uma mulher branca em nosso meio?

8. 0 que a sra./você. acha do "casamento" hoje em dia?

9. Me fale um pouco como é seu casamento. Como é sua vida no dia-a-dia com seu marido/companheiro? 
- Explorar : se é boa, ruim, com conflito de qualquer tipo, etc.

10.E do casamento entre brancos e negros. O que a sra acha?

- Explorar o que emergir

11.Como seu marido/ companheiro vê esta questão da liberdade da mulher hoje em dia?

12. Qual é o maior problema que a sra. acha que as mulheres enfrentam, hoje em dia, para manter um bom relacionamento com seus maridos/companheiros?

Explorar se o que diz é geral para todas as mulheres ou só para algumas?

Explorar: - No que a sra./você e seu marido/companheiro(a) mais concordam/ e discordam na relação

- como resolvem as divergências

13. E a sra/ você?Agora vamos fazer algumas questões íntimas. Como é a sua vida sexual com seu marido/companheiro?

-explorar menção ao prazer/desejo que emergirem;

- explorar tipos de problemas que emergem

14. Que tipo de problemas mais comuns a sra./você. acha que podem atrapalhar o relacionamento afetivo/sexuais dos casais? E no seu caso?

Explorar: - existência de conflitos em torno da_negociação sexual em relação:

- à própria prática sexual

- à infidelidade, etc

15. A sra./você acha que tem diferença de comportamento nas relações afetivas e sexuais entre homens brancos e negros?

16. E entre as mulheres brancas e negras? A sra./você acha que existe diferença de comportamento neste aspectos? 
17. O que a sra./você acha do uso da camisinha hoje em dia?

Explorar: - se associa o uso da camisinha à prevenção das DSTs/Aids e ou gravidez, ou ambos

- representação que faz do uso da camisinha

18. A sra poderia me falar que tipo de preocupação(oes) a existência da Aids trás para o seu relacionamento afetivo-sexual? Como a senhora procura solucionar? Explorar se procura se prevenir e como

19. Quando, ou em que situação, é que a sra./você. acha que a mulher deve pedir para o homem usar a camisinha?

Explorar: se identifica a necessidade do uso da camisinha entre casais com relacionamento estável, instável, fora do casamento, etc.

20. A sra./você usa com seu marido/companheiro e porque?

- Explorar: em caso positivo e em caso negativo o porque

- Explorar se precisou negociar com o parceiro o uso da camisinha

21. Alguma vez algum método contraceptivo que utilizou falhou?

Explorar circunstâncias e atitudes frente a situação

22.Alguma vez a sra./você. Interrompeu uma gravidez?

Se sim, explorar as razões e circunstâncias

Se teve apoio do marido/companheiro/parceiro

23.Alguma vez o sra./você foi vítima de uma situação que considerou violenta ou se sentiu agredida?

-Se sim, explorar situações e espaços do evento

- Se sim, explorar quais foram as motivações e desfechos 
-Se sim, explorações se houve motivações raciais

23.1 A sra já foi vítima de alguma situação em que se sentiu discriminada?

Se sim, explorar situações e espaços do evento

- Se sim, explorar quais foram as motivações e desfechos

-Se sim, explorações se houve motivações raciais

24. Como foi e é a participação de seu marido/companheiro em relação ao período de sua gestação, na maternidade e no cuidado com os filhos?

25. Como você vê a maternidade na vida da mulher em geral

26. Como foi/vê a maternidade em sua vida?

- Como foi no momento da gravidez

- Como é ser mãe hoje

- Se ainda quer ter filhos

- Como seria ter um novo filho nesse momento

27. A sra./você gostaria de comentar mais alguma coisa sobre o assunto? 
ANEXO III: Termo de Compromisso Ético da Pesquisa.

A participação das mulheres na pesquisa será voluntária. Elas serão convidadas a responder a um formulário semi-estruturado e a um roteiro temático, para a pesquisa em profundidade, contendo questões pessoais e opinativas acerca de problemas relativos à sua vida conjugal e outros relacionados à prevenção das DSTs/Aids e gravidez e opção por métodos contraceptivos. As entrevistas serão realizadas em salas fechadas sem a presença de outras pessoas. Será assegurada às mulheres a liberdade de não aceitar participar da pesquisa. Serão informadas, também, que Ihes será garantido o sigilo das informações e que suas falas gravadas serão identificadas por números e os formulários conterão nome fantasia e não sobrenome. Todas as mulheres que aceitarem participar da pesquisa poderão, a seu critério, assinar um termo de consentimento livre e esclarecido. A opção reside no fato de que pela tradição dos estudos antropológicos, a questão do anonimato é um direito ficando, nesse caso, a entrevista sob a responsabilidade única da entrevistadora. 
ANEXO IV: Consentimento Livre e Esclarecido

Fomos informadas a respeito da presente pesquisa intitulada Gênero e Raça: intersecções no campo da saúde reprodutiva que está sendo realizada pela aluna Raquel Souzas, sob orientação da professora Dra. Augusta Thereza de Alvarenga, aluna de pós-graduação da Faculdade de Saúde Pública da Universidade de São Paulo, com algumas mulheres negras e brancas. Fomos convidadas (os) a participar do estudo. Tivemos a explicação de que nossa participação consistirá em responder a um formulário e a um roteiro de perguntas dando informações pessoais e também nossa opinião sobre assuntos da nossa vida conjugal, além de outros relacionados à prevenção das DSTs/Aids e gravidez e outros assuntos relacionados à saúde reprodutiva. Foi também informado que a nossa entrevista será gravada e identificada apenas por um número e que nosso nome verdadeiro nunca será apresentado quando forem divulgados os resultados da pesquisa. Foi informado que poderemos não aceitar participar da pesquisa e que isto não interferirá. Este termo de consentimento foi lido para nós e decidimos participar da pesquisa de forma livre e esclarecida. Também fomos informadas que poderemos assinar, ou não, esse termo de consentimento com a garantia de que nosso nome será preservado.

Data_-_/_-_-____-__Assinatura da entrevistada

Assinatura da entrevistadora 


\section{ANEXO V}

Caracterização do grupo entrevistado

Idade atual

As mulheres estão distribuídas entre as idades 25 a 49 anos. Com isso procurou-

se levar em conta a idade adulta e reprodutiva.

Quadro 1 - Idades das mulheres

\begin{tabular}{|l|l|l|l|l|l|l|l|l|l|l|l|l|l|l|l|l|l|l|}
\hline Negras & 26 & 27 & 27 & 30 & 31 & 33 & 33 & 35 & 39 & 41 & 41 & 41 & 41 & 42 & 44 & 46 & 48 & 48 \\
\hline Brancas & 25 & 26 & 27 & 28 & 29 & 35 & 35 & 36 & 37 & 37 & 38 & 38 & 39 & 40 & 41 & 41 & 43 & 46 \\
\hline
\end{tabular}

Classificação por cor do casal

A Classificação por cor revela que os casais são mais endogâmicos do que exogâmicos.

Quadro 2 - Classificação por cor do casal

\begin{tabular}{|l|l|l|l|l|}
\hline & Branco & Negro & outra & total \\
\hline Negra & 4 & 14 & 0 & 18 \\
\hline Branca & 16 & 1 & 1 & 18 \\
\hline
\end{tabular}


Quanto as profissões as mulheres ocupavam os seguintes postos:

Quadro 3- Profissões das mulheres entrevistadas.

\begin{tabular}{|l|l|l|l|}
\hline Profissõe & Superior & Médio & Fundamental \\
\hline S & & & \\
\hline
\end{tabular}




\begin{tabular}{|c|c|c|c|}
\hline Negras & $\begin{array}{l}\text { 1Advogada; } \\
\text { 2Cientista social; } \\
\text { 3.Socióloga; } \\
\text { 4.Médica } \\
\text { Cardiologista } \\
\text { 5.Professora de } \\
\text { História } \\
6 . \text { Professora } \\
\text { ensino } \\
\text { fundamental }\end{array}$ & $\begin{array}{l}\text { 1. Era vendedora; } \\
\text { 2. faz salgados e } \\
\text { comida em geral; } \\
\text { 3. Auxiliar de } \\
\text { enfermagem; } \\
\text { 4. Ajudante de costura } \\
\text { 5. Bancária } \\
\text { 6. Costureira }\end{array}$ & $\begin{array}{l}\text { 1. Já Trabalhou De Auxiliar } \\
\text { De Limpeza E Domestica; } \\
\text { 2. Trabalhou Em Firma De } \\
\text { 3. Ajudante Geral; } \\
\text { Fábrica; } \\
\text { 4. Trabalha Fazendo Bicos } \\
\text { De Crochê; } \\
\text { 5. Auxiliar De Enfermagem } \\
\text { 6. Ajudante }\end{array}$ \\
\hline Brancas & $\begin{array}{l}\text { 1.Psicóloga } \\
\text { Clinico(Profissional } \\
\text { Liberal); } \\
\text { 2.Empresária, } \\
\text { atua como } \\
\text { Socióloga; } \\
\text { 3. Funcionária } \\
\text { Pública licenciada } \\
\text { e contratada por } \\
\text { um Centro de }\end{array}$ & $\begin{array}{l}\text { 1.Assistente } \\
\text { Administrativo; } \\
\text { 2. Sindica e trabalha } \\
\text { com diagramação e } \\
\text { editoração } \\
\text { eletrônica(freelancer); } \\
\text { 3. decoradora; } \\
\text { 4. enfermagem(técnica) } \\
\text { 5. Ex Vendedora } \\
\text { 6. Ex telefonista }\end{array}$ & $\begin{array}{l}\text { 1. Promotora de vendas da } \\
\text { 2. Auxiliar de limpeza; } \\
\text { 3. Auxiliar de importação e } \\
\text { exportação } \\
\text { 4. Faz limpeza } \\
\text { 5. Ex promotora de vendas } \\
\text { 6. Ex Detive Particular }\end{array}$ \\
\hline
\end{tabular}




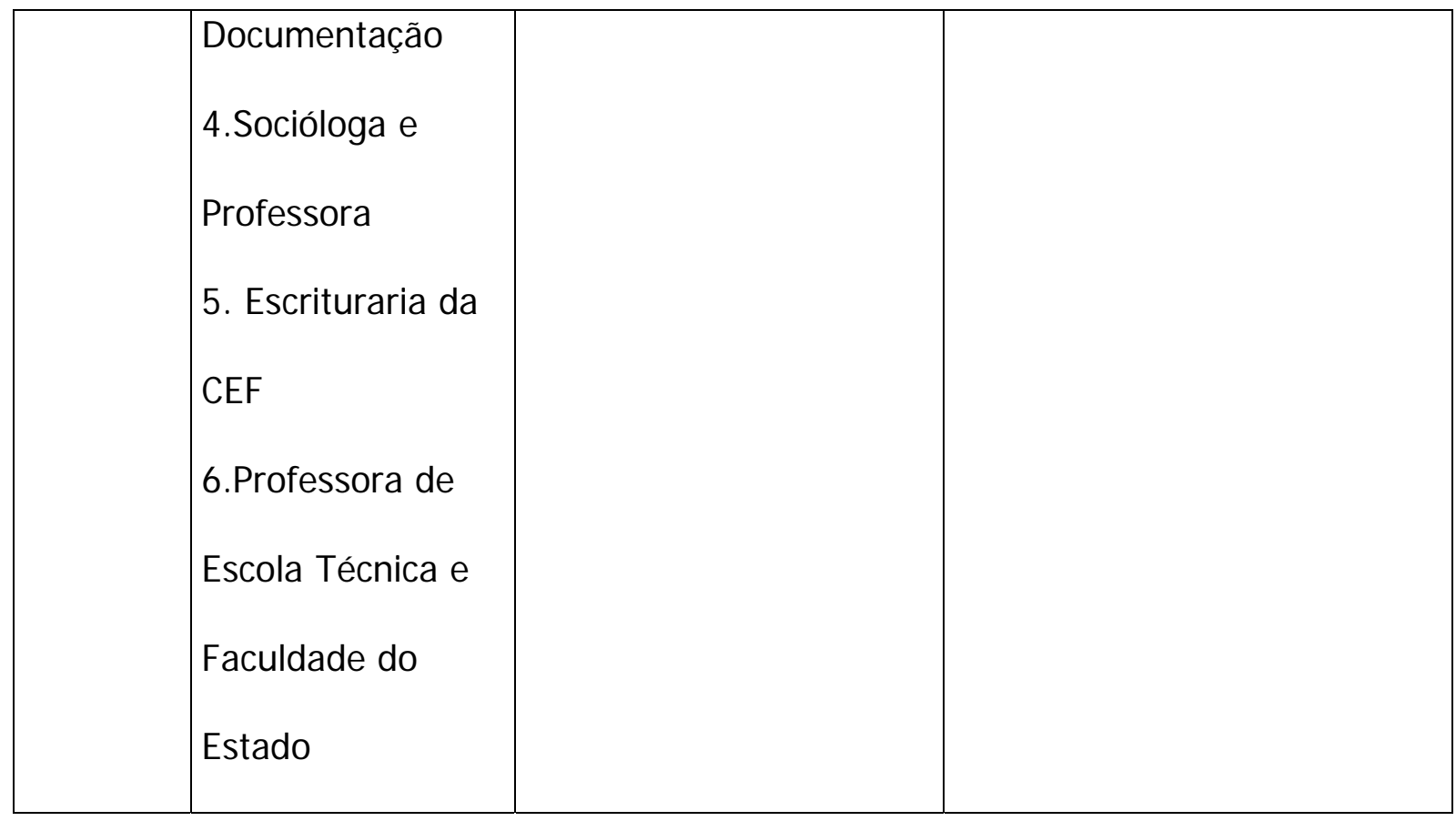

Demonstrativo da história reprodutiva das mulheres negras

Quadro 4- Mulheres Negras

\begin{tabular}{|c|c|c|c|c|c|c|c|}
\hline $\begin{array}{l}\text { Nome } \\
\text { Codnom } \\
\text { e }\end{array}$ & $\begin{array}{l}\text { Tempo de } \\
\text { União }\end{array}$ & $\begin{array}{l}\text { Idade } \\
\text { ao } \\
\text { casar }\end{array}$ & Método Atual & \begin{tabular}{|l|} 
Menarca \\
\\
idade
\end{tabular} & $\begin{array}{l}\text { 1a } \\
\text { Relaçãa } \\
0\end{array}$ & $\begin{array}{l}\text { № } \\
\text { filhos }\end{array}$ & \begin{tabular}{|l|} 
Abortos \\
(P)rovoca \\
do \\
(E)spontâ \\
neo \\
\end{tabular} \\
\hline \multicolumn{8}{|c|}{ Ensino Superior } \\
\hline Roberta & 16 & $\begin{array}{l}25 \text { ou } \\
26\end{array}$ & camisinha & 12 & 19 & 2 & 0 \\
\hline Regina & 5 & 34 & camisinha & 14 & 22 & 0 & $1(\mathrm{P})$ \\
\hline Marta & 3 & 41 & $\begin{array}{l}\text { Coito } \\
\text { interrompido }\end{array}$ & 12 & 26 & 0 & $1(\mathrm{P})$ \\
\hline Luisa & 2 & 31 & Camisinha & 13 & 27 & 0 & 0 \\
\hline Luci & $\begin{array}{l}2 \text { anos e } 2 \\
\text { meses }\end{array}$ & 25 & camisinha & 12 & 17 & 0 & $1(P)$ \\
\hline $\begin{array}{l}\text { Hortênsi } \\
\text { a }\end{array}$ & 16 & 25 & laqueadura & 14 ou15 & 20 & 4 & $1(\mathrm{P})$ \\
\hline \multicolumn{8}{|c|}{ Ensino Médio } \\
\hline Ana & 19 & 27 & laqueadura & 16 & 27 & 3 & 0 \\
\hline Amanda & 15 & 32 & $\begin{array}{l}\text { histerectomiza } \\
\text { da }\end{array}$ & 12 & 19 & 1 & $1(P)$ e3(E) \\
\hline Marina & 10 & 21 & Sem método & 12 & 20 & 1 & $1(E)$ \\
\hline Vânia & & 18 & Anticoncepcio & 11 & 17 & 1 & 0 \\
\hline
\end{tabular}




\begin{tabular}{|l|l|l|l|l|l|l|l|}
\hline & 8 & & nal injetável & & & & \\
\hline $\begin{array}{l}\text { Maria } \\
\text { Celia }\end{array}$ & 12 & 29 & laqueadura & 15 & 27 & 2 & $2(\mathrm{E})$ \\
\hline $\begin{array}{l}\text { Maria } \\
\text { Wilma }\end{array}$ & $\begin{array}{l}7 \text { anos e } \\
\text { meio }\end{array}$ & 34 & $\begin{array}{l}\text { Estava } \\
\text { grávida }\end{array}$ & 15 & 24 & 2 & $1(\mathrm{E})$ \\
\hline \begin{tabular}{l} 
Ensino Fundamental \\
\hline Pámela
\end{tabular} & 18 & 24 & laqueadura & 15 & 17 & 2 & $1(\mathrm{E})$ \\
\hline Rosana & 16 & 19 & laqueadura & 12 & 18 & 3 & 0 \\
\hline Dalila & 16 & 17 & Sem método & 12 & 17 & 2 & 0 \\
\hline Eliane & 16 & 15 & $\begin{array}{l}\text { Laqueadura e } \\
\text { camisinha } \\
\text { masculina }\end{array}$ & 11 & 15 & 3 & 0 \\
\hline Sabrina & 7 & 20 & $\begin{array}{l}\text { Tirou as } \\
\text { trompas }\end{array}$ & 14 & 15 & 3 & $1(\mathrm{E})$ \\
\hline Regiane & 23 & 25 & Laqueadura & 9 & 23 & 3 & 0 \\
\hline
\end{tabular}


Demonstrativo da história reprodutiva das mulheres brancas Quadro 5 Mulheres Brancas

\begin{tabular}{|c|c|c|c|c|c|c|c|}
\hline $\begin{array}{l}\text { Nome } \\
\text { codnome }\end{array}$ & $\begin{array}{r}\text { Tempo de } \\
\text { União }\end{array}$ & $\begin{array}{l}\text { Idad } \\
\text { e ao } \\
\text { casar }\end{array}$ & $\begin{array}{r}\text { Método } \\
\text { atual }\end{array}$ & $\begin{array}{r}\text { Menarca } \\
/ \\
\text { idade }\end{array}$ & $\begin{array}{r}\text { Idade } \\
\text { da } 1 \underline{a} \\
\text { relaçã } \\
0 \\
\text { sexual }\end{array}$ & $\begin{array}{l}\text { № de } \\
\text { filhos }\end{array}$ & $\begin{array}{r}\text { Abortos } \\
\text { (P)rovocado } \\
\text { (E)espontan } \\
\text { eo }\end{array}$ \\
\hline \multicolumn{8}{|c|}{ Ensino Superior } \\
\hline Sonia & 15 & 20 & vasectomi & 14 & 1 & 1 & $1(P)$ \\
\hline Solimar & 14 & 26 & camisinha & 15 & 16 & 0 & $1(E)$ e $1(P)$ \\
\hline Suzana & 10 & 31 & camisinha & 11 & 31 & 2 & 0 \\
\hline Sara & 11 & 27 & tabelinha & 12 ou13 & 21 & 3 & 0 \\
\hline Juçara & 2 & 28 & camisinha & 11 & 17 & 0 & 0 \\
\hline Suzete & 6 & 31 & DIU & 13 & 23 & 1 & $3(P)$ \\
\hline \multicolumn{8}{|c|}{ Ensino Médio } \\
\hline Carla & 17 & 18 & vasectomi & 12 & 15 & 2 & 0 \\
\hline Teresa & 14 & 22 & vasectomi & 16 & 22 & 2 & 0 \\
\hline Amalia & 11 & 28 & vasectomia & 12 & 22 & 1 & 0 \\
\hline Joana & 6 & 31 & camisinha & 13 & 18 & 0 & $2(P)$ el(E) \\
\hline Gilmara & 9 & 18 & camisinha & 11 & 16 & 1 & 0 \\
\hline Cris & 6 & 19 & Sem & 14 & 16 & 2 & 0 \\
\hline \multicolumn{8}{|c|}{ Ensino Fundamental } \\
\hline Gorete & 22 & 19 & laqueadur & 11 & 19 & 4 & \\
\hline Lucia & $\begin{array}{r}15 \text { anos e } \\
8 \text { meses }\end{array}$ & 22 & Vasectomi & 11 & 15 & 3 & 0 \\
\hline Denise & 8 & 35 & $\begin{array}{l}\text { Sem } \\
\text { metodo }\end{array}$ & 10 & 19 & 2 & $1(E)$ \\
\hline Rosa & 9 & 30 & camisinha & 15 ou 16 & $210 u 2$ & 2 & 0 \\
\hline Mary & 25 & 22 & Sem & 12 & 22 & 1 & 0 \\
\hline NP & 10 & 16 & $\begin{array}{r}\text { Camisinha } \\
\text { e coito } \\
\text { interrompi } \\
\text { do } \\
\end{array}$ & 9 & 14 & 2 & 0 \\
\hline
\end{tabular}


ANEXO VI - Plano de Análise

Objetivo1

5. Desvelando relações específicas entre conjugalidade, gênero e raça no contexto da Saúde Reprodutiva

5. 1 Visões de mundo acerca de "mulher" hoje em dia

5.1.1 O trabalho da mulher fora de casa

5.1.2. A Liberdade

As mulheres brancas

As mulheres negras

\subsubsection{O Casamento}

Mulheres de ensino fundamental

Mulheres de ensino médio

Mulheres de nível superior

\subsubsection{As maternidades}

5.2 idéias de negrura, idéias de brancura na ótica de mulheres negras e brancas

As mulheres negras sobre elas mesmas

As mulheres brancas por elas mesmas

5. 3 Visões de mundo acerca da diferença

Objetivo 2 - Caracterizando práticas sociais homogêneas e diferenciadas em relação à prevenção da gravidez e do HIV/Aids na intersecção conjugalidade, relações de gênero e raça 
Objetivo 3 Identificar dilemas e contradições nas práticas contraceptivas e na prevenção do HIV/Aids, sob a ótica das relações de gênero e de raça

Percepção e uso de métodos contraceptivos

Abortos

Laqueadura: uma medida radical

Percepção e uso da camisinha

Preocupações com relação a Aids

A conjugalidade de mulheres negras e brancas

A sexualidade de mulheres negras e brancas

0 discurso sobre a discriminação e o preconceito

A constatação do racismo

Situações em que constatou discriminação

Considerações finais 